Supporting Information for

\title{
Remote Ligand Modifications Tune Electronic Distribution and Reactivity in Site-Differentiated, High Spin Iron Clusters: Flipping Scaling Relationships
}

\author{
Charles H. Arnett, Jens T. Kaiser, and Theodor Agapie* \\ Division of Chemistry and Chemical Engineering, California Institute of Technology, Pasadena, \\ California 91125, United States
}

\section{Table of Contents}

Experimental and Synthetic Details............................................... 2-3

Synthetic Procedures............................................................. 4-6

Spectral Characterization............................................................ $7-16$

Variable Temperature IR Spectroscopy...........................................17-21

Variable Temperature NMR Spectroscopy and Thermodynamic Measurements...............22-37

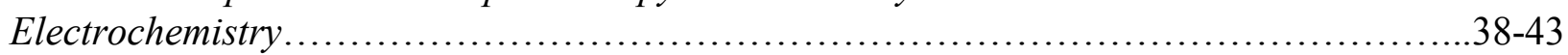

Magnetic Measurements.....................................................44-57

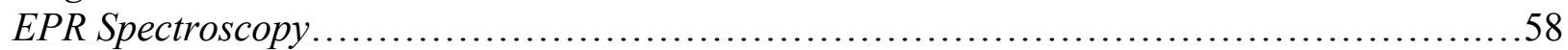

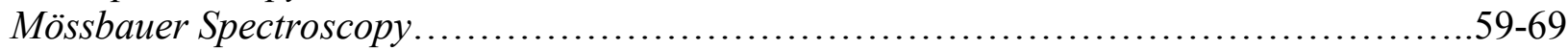

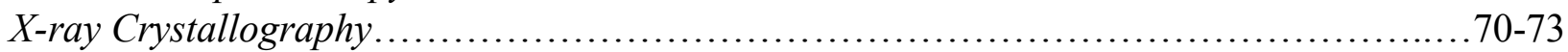

$X$-ray Absorption and Anomalous Diffraction ........................................... 74-75

Summary Tables............................................................. $76-77$

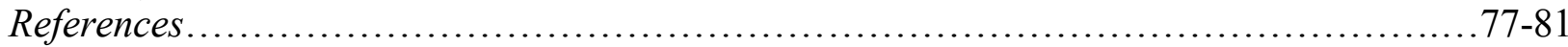




\section{Experimental and Synthetic Details}

\section{General Considerations}

All reactions were performed at room temperature in a nitrogen filled M. Braun glovebox or using standard Schlenk techniques unless otherwise specified. Glassware was oven dried at $140^{\circ} \mathrm{C}$ for at least two hours prior to use, and allowed to cool under vacuum. The $N$-substituted aryl imidazoles ${ }^{\mathrm{pOMe}} \mathrm{ArIm}$ and ${ }^{\mathrm{pNMe} 2} \mathrm{ArIm}$ were synthesized from the corresponding anilines, glyoxal, formaldehyde and aqueous ammonia based on a literature procedure. ${ }^{1 \mathrm{pCF} 3} \mathrm{ArIm}$ was prepared from the corresponding aniline, thiophosgene and aminoacetylaldehyde diethyl acetal based on an adapted literature procedure. ${ }^{1}$ All aryl imidazoles were further purified by sublimation at $100^{\circ} \mathrm{C}$ under vacuum. $\mathrm{Fe}(\mathrm{OTf})_{2}(\mathrm{MeCN})_{2}{ }^{2}{ }^{2}[\mathrm{Fc}][\mathrm{OTf}]^{3}$ and $\mathrm{Na}\left[\mathrm{BAr}^{\mathrm{F}}{ }_{24}\right]^{4}$ were prepared according to literature procedures. [ $\left.\mathrm{Fc}^{*}\right][\mathrm{OTf}]$ was prepared by oxidation of $\mathrm{Fc}^{*}$ with [Fc][OTf] in dichloromethane followed by crystallization from dichloromethane/pentane. $\mathrm{LFe}_{3}(\mathrm{OTf})_{3}$, $\left[\mathrm{LFe}_{3} \mathrm{O}(\mathrm{PhIm})_{3} \mathrm{Fe}\right][\mathrm{OTf}]_{2}\left(\mathbf{1}^{\mathbf{H}}\right)$ and $\left[\mathrm{LFe}_{3} \mathrm{O}(\mathrm{PhIm})_{3} \mathrm{Fe}\right]$ were prepared as previously described. ${ }^{5}$ All other reagents were obtained commercially unless otherwise noted and typically stored over activated $4 \AA$ molecular sieves. Tetrahydrofuran was dried using sodium/benzophenone ketyl, degassed with three freeze-pump-thaw cycles, vacuum transferred, and stored over $3 \AA$ molecular sieves prior to use. Dichloromethane, diethyl ether, benzene, acetonitrile, hexanes, and pentane were dried by sparging with nitrogen for at least 15 minutes, then passing through a column of activated A2 alumina under positive nitrogen pressure. Dichloromethane- $d_{2}$ was dried over calcium hydride, degassed by three freeze-pump-thaw cycles, and vacuum transferred prior to use. ${ }^{1} \mathrm{H}$ and ${ }^{19} \mathrm{~F}$ NMR spectra were recorded on a Varian 300 or $400 \mathrm{MHz}$ spectrometer. All chemical shifts $(\delta)$ are reported in ppm, and coupling constants $(J)$ are in hertz. The ${ }^{1} \mathrm{H}-\mathrm{NMR}$ spectra were referenced using residual $\mathrm{H}$ impurity in the deuterated solvent, whereas the ${ }^{19} \mathrm{~F}$ chemical shifts are reported relative to the internal lock signal. UV-Vis spectra were recorded on a Varian Cary Bio 50 spectrophotometer. Infrared (ATR-IR) spectra were recorded on a Bruker ALPHA ATR-IR spectrometer. Solution ATR-IR spectra were recorded on a Mettler Toledo iC10 ReactIR. Elemental analyses were performed at Caltech.

\section{Physical Methods}

Mössbauer Measurements. Zero field ${ }^{57} \mathrm{Fe}$ Mössbauer spectra were recorded in constant acceleration on a spectrometer from See Co (Edina, MN) equipped with an SVT-400 cryostat (Janis, Wilmington, WA). The quoted isomer shifts are relative to the centroid of the spectrum of $\alpha-\mathrm{Fe}$ foil at room temperature. Unless otherwise noted, samples were prepared by grinding polycrystalline (20-50 mg) into a fine powder and pressed into a homogenous pellet with boron nitride in a cup fitted with a screw cap. The data were fitted to Lorentzian lineshapes using the program WMOSS (www.wmoss.org).

EPR Spectroscopy. X-band EPR spectra were collected on a Bruker EMX spectrometer equipped with a He flow cryostat. Samples were prepared as frozen glasses in 4:5 propionitrile/butyronitrile or 2-MeTHF. Spectra were collected with microwave powers ranging from $0.5 \mathrm{~mW}$ to $8 \mathrm{~mW}$ with modulation amplitudes of 4 Gauss. Spectral simulations were conducted with EasySpin. ${ }^{6}$

Magnetic Measurements. Magnetic measurements were conducted with a Quantum Design MPMS3 SQUID Magnetometer at the University of California, Los Angeles. Polycrystalline samples were wrapped in plastic film and placed in a gelatin capsule. The capsule was then inserted into a plastic straw. Magnetization data at $100 \mathrm{~K}$ from 0 to $4 \mathrm{~T}$ were collected to 
confirm the absence of ferromagnetic impurities. Direct current variable temperature magnetic susceptibility measurements were collected between 1.8 and $300 \mathrm{~K}$ with a $0.1 \mathrm{~T}$ field. Reduced magnetization data was collected between 1.8 and $9 \mathrm{~K}$ at fields between 1 and $7 \mathrm{~T}$. Magnetic susceptibility data was corrected for diamagnetism of the sample, estimated using Pascal's constants, as well as the sample holder. Magnetic susceptibility and reduced magnetization data was simulated with PHI. ${ }^{7}$

Electrochemical Measurements. CVs were recorded with a Pine Instrument Company AFCBP1 bipotentiostat using the AfterMath software package. All measurements were performed in a three electrode cell, which consisted of (1) a glassy carbon working electrode, (2) a Pt wire counter electrode, and (3) a Ag wire reference electrode. Dry solvent that contained $0.1 \mathrm{M}$ $n \mathrm{Bu}_{4} \mathrm{NPF}_{6}$ was employed as the electrolyte solution for all electrochemical measurements. All electrochemical measurements were performed at room temperature in an $\mathrm{M}$. Braun nitrogen filled glovebox. The ferrocene/ferrocenium $\left(\mathrm{Fc} / \mathrm{Fc}^{+}\right)$redox couple was used as an internal standard for all measurements.

X-ray Crystallography. For compounds $\mathbf{1}^{\mathrm{CF} 3}, \mathbf{1}^{\mathrm{H}}, \mathbf{2}^{\mathrm{CF} 3}, \mathbf{1}^{\mathrm{H}}$, and $\mathbf{1}^{\mathrm{NMe} 2}$, low-temperature $(100 \mathrm{~K})$ diffraction data $(\varphi$-and $\omega$-scans) were collected on a Bruker AXS D8 VENTURE KAPPA diffractometer coupled to a PHOTON 100 CMOS detector with Mo K $\alpha$ radiation $(\lambda=0.71073 \AA$ ) or with $\mathrm{Cu} \mathrm{K \alpha}(\lambda=1.54178 \AA)$. All diffractometer manipulations, including data collection, integration, and scaling were carried out using the Bruker APEXII software. ${ }^{8}$ Absorption corrections were applied using SADABS. ${ }^{9}$ Structures were solved by direct methods using SHELXS $^{10}$ and refined against $F 2$ on all data by full-matrix least squares with SHELXL-2014 ${ }^{11}$ interfaced with Olex2-1.2.8 ${ }^{12}$ and using established refinement techniques. All non-hydrogen atoms were refined anisotropically, except heavily disordered solvent in some cases. All hydrogen atoms were included into the model at geometrically calculated positions and refined using a riding model. The isotropic displacement parameters of all hydrogen atoms were fixed to 1.2 times the $U$ value of the atoms they are linked to (1.5 times for methyl groups). All disordered atoms were refined with the help of similarity restraints on the 1,2- and 1,3-distances and displacement parameters as well as enhanced rigid bond restraints for anisotropic displacement parameters. Due to the size of the compounds, most crystals included solvent accessible voids, which tended to contain disordered solvent. In most cases, this disorder could be modeled satisfactorily. Furthermore, the long-range order of these crystals and amount of high angle data was in some cases not ideal, due to desolvation of the crystals and/or solvent disorder.

Positionally Resolved X-ray Crystallography. Radiation damage was a significant issue (Supplementary Fig. 89), and we have only been able to obtain acceptable quality data for $2^{\text {CF3 }}$. For $2^{\mathbf{C F} 3}$, Anomalous diffraction data was collected at SSRL beamline 12-2. Samples were mounted at $100 \mathrm{~K}$ and subjected to a "MAD-scan at the Fe K-edge. Wavelenghts for subsequent datasets were chosen as $+/-10 \mathrm{eV}$ around the inflection point. A dataset at $17 \mathrm{keV}$ was collected on a PILATUS 6M detector at a distance of $188 \mathrm{~mm}$ to serve as a reference. Subsequently, full spheres of diffraction data were collected across the edge from low to high energy. The data were processed with XDS and brought on a common scale with XSCALE. ${ }^{13}$ Structures previously solved and refined using SHELX were converted into PDB format using MERCURY. This file was used in combination with the XDS_ASCII.HKL from the $17 \mathrm{keV}$ dataset to refine the structure in PHENIX. ${ }^{14}$ Setting the geometry target weight wc to zero allows for unrestrained refinement and results in an R-factor (5.35\%) comparable to the original refinement in SHELXL. This refined model was then subjected to refinement against datasets at the energies across the Fe K-edge. The only parameters refined were f' and f' for the individual Fe atoms. 


\section{Synthetic Procedures}

Preparation of $\left[\mathrm{LFe}_{3} \mathrm{O}(\mathrm{ArIm}-\mathrm{H})_{\mathbf{n}}(\mathrm{OTf})_{3-\mathrm{n}}\right][\mathrm{OTf}]_{\mathbf{n}}$ Precursors. A solution of the $\mathrm{N}$-aryl imidazole ArIm-H (2.34 mmol, 3.1 equiv.) in dichloromethane ( $3 \mathrm{~mL})$ was added dropwise to a stirring suspension of $\mathrm{LFe}_{3}(\mathrm{OTf})_{3}(1.01 \mathrm{~g}, 0.689 \mathrm{mmol}, 1$ equiv. $)$ in dichloromethane $(5 \mathrm{~mL})$. The resulting orange solution was allowed to stir for one hour, at which point it was frozen in a glovebox cold well. The frozen mixture was removed from the cold well and iodosobenzene (152 mg, 0.689 mmol, 1 equiv.) was added upon thawing. After stirring for one hour, the resulting dark brown solution was concentrated under vacuum. Tetrahydrofuran was added to the residue and the suspension was stirred overnight. The precipitate was then collected on a bed of Celite, washed with additional tetrahydrofuran, and then eluted with dichloromethane. The volatiles were removed under reduced pressure. Prior to use in subsequent reactions, the trimetallic precursors $\left[\mathrm{LFe}_{3} \mathrm{O}(\mathrm{ArIm})_{\mathrm{n}}(\mathrm{OTf})_{3-\mathrm{n}}\right][\mathrm{OTf}]_{\mathrm{n}}$ were crystallized by diffusion of diethyl ether in concentrated dichloromethane solutions of the compound.

$\left[\mathbf{L F e}_{3} \mathbf{O}\left({ }^{\text {pCF3 }} \mathbf{A r I m}-\mathbf{H}\right)_{3}\right][\mathbf{O T f}]_{3}$, (A). ${ }^{1} \mathrm{H}$ NMR (300 MHz, $\left.\mathrm{CD}_{2} \mathrm{Cl}_{2}\right) \delta 102.04$ (b), 99.56 (b), 97.30 (b), 79.75 (b), 77.62 (b), 74.10 (b), 68.77 (b), 67.29 (b), 65.72 (b), 64.94 (b), 58.13 (b), 49.75 (b), 48.96 (b), 47.17 (b), 46.14 (b), 44.44 (b), 44.00 (b), 39.36 (b), 16.23 (b), 15.08 (b), 13.81 (b), 13.12 (b), 12.17 (b), 10.75 (b), 9.11 (b), -1.07 (b), -4.23 (b), -6.97 (b). ${ }^{19} \mathrm{~F} \mathrm{NMR}\left(300 \mathrm{MHz}, \mathrm{CD}_{2} \mathrm{Cl}_{2}\right)$ $\delta-9.16(\mathrm{~s}),-63.05(\mathrm{~s}),-78.23(\mathrm{~s})$.

[LFe $\left.{ }_{3} \mathbf{O}\left({ }^{\text {pOMe }} \mathbf{A r I m - H}\right)_{3}\right][\mathbf{O T f}]_{3}$, (B). ${ }^{1} \mathrm{H}$ NMR (300 MHz, $\left.\mathrm{CD}_{2} \mathrm{Cl}_{2}\right) \delta 101.64$ (b), 99.07 (b), 96.59 (b), 79.68 (s), 78.40 (b), 77.12 (b), 76.14 (b), 69.14 (b), 66.81 (s). 66.20 (s), 63.56 (s), 57.44 (s), 50.27 (s), 48.93 (b), 47.57 (s), 46.12 (s), 44.30 (s), 43.76 (s), 42.80 (s), 41.75 (b), 26.24 (b), 17.06 (s), 16.10 (s), 15.49 (s), 14.37 (s), 13.98 (b), 13.16 (s), 12.24 (s), 11.33 (b), 10.64 (s), 9.95 (s), 9.68 (b), 8.54 (s), 6.89 (s), 6.52 (s), 0.68 (b), -1.31 (b), -3.48 (b), -6.86 (b). ${ }^{19} \mathrm{~F}$ NMR (300 $\left.\mathrm{MHz}, \mathrm{CD}_{2} \mathrm{Cl}_{2}\right) \delta-10.12(\mathrm{~s}),-78.01(\mathrm{~s})$.

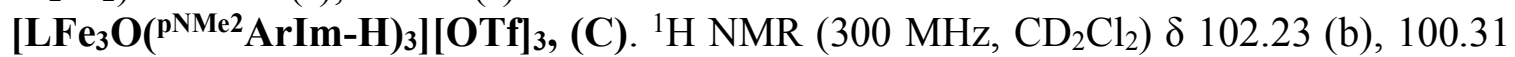
(b), 97.97 (b), 95.10 (b), 79.19 (b), 76.20 (b), 73.29 (b), 68.60 (b), 67.29 (s), 65.21 (s), 63.74 (b), 60.72 (b), 55.83 (s), 49.62 (s), 48.48 (b), 45.87 (s), 45.30 (b), 43.42 (s), 42.69 (s), 41.54 (s), 26.69 (b), 16.04 (s), 15.49 (s), 15.21 (s), 13.88 (s), 13.67 (s), 13.39 (s), 12.23 (s), 11.85 (s), 10.85 (s), 10.24 (s), 9.25 (s), 8.54 (b), -0.01 (b), -2.16 (b), -4.53 (b), -8.23 (b). ${ }^{19} \mathrm{~F}$ NMR (300 MHz, $\left.\mathrm{CD}_{2} \mathrm{Cl}_{2}\right)$ $\delta-8.79(\mathrm{~b}),-78.10(\mathrm{~s})$.

Preparation of $\left[\mathbf{L F e}_{3} \mathbf{O}(\mathbf{A r I m})_{3} \mathbf{F e}\right][\mathbf{O T f}]_{2}$. A solution of $\mathrm{ArIm}-\mathrm{H}(0.40 \mathrm{mmol}, 1$ equiv. $)$ in $3 \mathrm{~mL}$ tetrahydrofuran was added to a suspension of $\left[\mathrm{LFe}_{3} \mathrm{O}(\mathrm{ArIm}-\mathrm{H})_{3}\right][\mathrm{OTf}]_{3}(0.40 \mathrm{mmol}, 1$ equiv.) $3 \mathrm{~mL}$ of tetrahydrofuran. The mixture was then frozen in a glovebox cold well. The frozen mixture was removed from the cold well and a thawing solution of $\mathrm{Na}\left[\mathrm{N}\left(\mathrm{SiMe}_{3}\right)_{2}\right]$ (232 $\mathrm{mg}, 1.27$ mmol, 3.2 equiv.) in $2 \mathrm{~mL}$ of tetrahydrofuran was added dropwise. After stirring for 1 hour at room temperature, the mixture was once again frozen in the cold well. The frozen mixture was then removed from the cold well and a thawing slurry of $\mathrm{Fe}(\mathrm{OTf})_{2}(\mathrm{MeCN})_{2}(182 \mathrm{mg}, 0.42 \mathrm{mmol}, 1.05$ equiv.) in $3.5 \mathrm{~mL}$ of tetrahydrofuran was added dropwise. After stirring for 22 hours at room temperature, the mixture was filtered over a bed of Celite, washed with additional tetrahydrofuran and eluted with dichloromethane. The volatiles were removed under reduced pressure to afford $\left[\mathrm{LFe}_{3} \mathrm{O}(\mathrm{ArIm})_{3} \mathrm{Fe}\right][\mathrm{OTf}]_{2}$ as a dark brown solid.

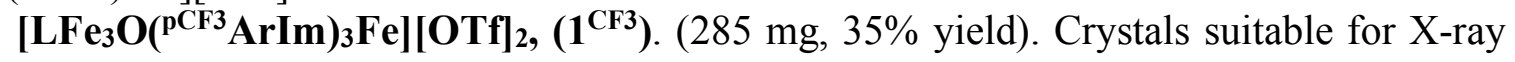
diffraction were grown by diffusion of diethyl ether into a dilute solution of the compound in dichloromethane/acetonitrile (1:1). ${ }^{1} \mathrm{H} \mathrm{NMR}\left(300 \mathrm{MHz}, \mathrm{CD}_{2} \mathrm{Cl}_{2}\right) \delta 114.11$ (b), 74.98 (s). 72.14 (s), 67.45 (b), 49.60 (s), 46.99 (s), 42.82 (s), 26.35 (b), 19.06 (s), 13.48 (s), 12.78 (s), 12.52 (s), -1.23 (s), $-4.76(\mathrm{~s}) .{ }^{19} \mathrm{~F}$ NMR $\left(300 \mathrm{MHz}, \mathrm{CD}_{2} \mathrm{Cl}_{2}\right) \delta-78.83(\mathrm{~s}),-62.93(\mathrm{~s}) . \mathrm{UV}-\mathrm{Vis}\left(\mathrm{CH}_{3} \mathrm{CN}\right)\left[\varepsilon\left(\mathrm{M}^{-1} \mathrm{~cm}^{-}\right.\right.$ 
$\left.{ }^{1}\right)$ ]: $447 \mathrm{~nm}\left(7.4 \times 10^{3}\right)$. Anal. Calcd (\%) for $\mathrm{C}_{89} \mathrm{H}_{57} \mathrm{~F}_{15} \mathrm{Fe}_{4} \mathrm{~N}_{12} \mathrm{O}_{10} \mathrm{~S}_{2}$ : C, 52.74; H, 2.83; N, 8.29. Found: C, 52.57; H, 3.02; N, 8.26.

[LFe $\left.{ }_{3} \mathbf{O}\left({ }^{{ }^{O M e}} \mathbf{A r I m}\right)_{3} \mathbf{F e}\right][\mathrm{OTf}]_{2}$, (1 $\left.{ }^{\text {OMe }}\right)$. (100 mg, 13\% yield). Crystals suitable for X-ray diffraction were grown by diffusion of diethyl ether into a dilute solution of the compound in dichloromethane/acetonitrile (1:1). ${ }^{1} \mathrm{H} \mathrm{NMR}\left(300 \mathrm{MHz}, \mathrm{CD}_{2} \mathrm{Cl}_{2}\right) \delta 116.47$ (b), 75.69 (s), 73.99 (s), 70.55 (b), 51.42 (s), 47.08 (s), 46.35 (s), 21.36 (b), 20.18 (s), 14.67 (s), 12.29 (s), -4.30 (s), -6.33 (s). ${ }^{19} \mathrm{~F}$ NMR $\left(300 \mathrm{MHz}, \mathrm{CD}_{2} \mathrm{Cl}_{2}\right) \delta$-78.32. UV-Vis $\left(\mathrm{CH}_{2} \mathrm{Cl}_{2}\right)\left[\varepsilon\left(\mathrm{M}^{-1} \mathrm{~cm}^{-1}\right)\right]: 461 \mathrm{~nm}\left(8.14 \times 10^{3}\right)$. Anal. Calcd (\%) for $\mathrm{C}_{89} \mathrm{H}_{66} \mathrm{~F}_{6} \mathrm{Fe}_{4} \mathrm{~N}_{12} \mathrm{O}_{13} \mathrm{~S}_{2}$ : C, 55.88; H, 3.48; N, 8.79. Found: C, 55.54; H, 3.66; N, 8.51.

$\left.\left[\mathrm{LFe}_{3} \mathrm{O}\left({ }^{\mathrm{pNMe} 2} \mathrm{ArIm}\right)_{3} \mathrm{Fe}\right][\mathrm{OTf}]_{2},{\left(\mathbf{1}^{\mathrm{NMe}}\right)}\right)$ (79.4 $\mathrm{mg}, 10 \%$ yield). Crystals suitable for X-ray diffraction were grown by diffusion of diethyl ether into a dilute solution of the compound in dichloromethane/acetonitrile (1:1). ${ }^{1} \mathrm{H}$ NMR (300 MHz, $\left.\mathrm{CD}_{2} \mathrm{Cl}_{2}\right) \delta 115.72(\mathrm{~b}), 74.71$ (s), 73.37 (s), 70.44 (b), 51.16 (s), 46.76 (s), 45.61 (s), 21.71 (b), 20.46 (s), 14.88 (s), 12.35 (s), -3.58 (b), -7.05 (s). ${ }^{19} \mathrm{~F}$ NMR $\left(300 \mathrm{MHz}, \mathrm{CD}_{2} \mathrm{Cl}_{2}\right) \delta-79.33$. UV-Vis (acetone) $\left[\varepsilon\left(\mathrm{M}^{-1} \mathrm{~cm}^{-1}\right)\right]: 443 \mathrm{~nm}\left(7.85 \times 10^{3}\right)$, $598 \mathrm{~nm}\left(2.90 \times 10^{3}\right)$. Anal. Calcd (\%) for $\mathrm{C}_{92} \mathrm{H}_{75} \mathrm{~F}_{6} \mathrm{Fe}_{4} \mathrm{~N}_{15} \mathrm{O}_{10} \mathrm{~S}_{2}$ : C, 56.60; H, 3.87; N, 10.76 . Found: C, 56.00; H, 4.05; N, 10.46 .

$\left[\mathrm{LFe}_{3} \mathrm{O}\left({ }^{\mathrm{PCF} 3} \mathrm{ArIm}\right){ }_{3} \mathrm{Fe}\right][\mathrm{OTf}],\left(^{\mathrm{CF} 3}\right)$. A solution of $\mathrm{Cp}^{*}{ }_{2} \mathrm{Co}(22.3 \mathrm{mg}, 0.068 \mathrm{mmol}, 1.0$ equiv.) in $1 \mathrm{~mL}$ tetrahydrofuran was added dropwise to a stirring suspenion of $\left[\mathrm{LFe}_{3} \mathrm{O}\left({ }^{\mathrm{pCF} 3} \mathrm{ArIm}\right)_{3} \mathrm{Fe}\right][\mathrm{OTf}]_{2}(137.5 \mathrm{mg}, 0.068 \mathrm{mmol}, 1.0$ equiv. $)$ in $4 \mathrm{~mL}$ of tetrahydrofuran. After one hour, the reaction mixture was filtered over a bed of Celite to remove $\left[\mathrm{Cp}_{2}{ }_{2} \mathrm{Co}\right][\mathrm{OTf}]$. The volatiles were removed under reduced pressure to afford $\left[\mathrm{LFe}_{3} \mathrm{O}\left({ }^{\mathrm{pCF} 3} \mathrm{ArIm}\right){ }_{3} \mathrm{Fe}\right][\mathrm{OTf}]$ as a pinkpurple solid (110 mg, 86\% yield). Crystals suitable for X-ray diffraction were obtained by diffusion of diethyl ether into a dilute solution of the compound in 1:1 dichloromethane:acetonitrile. ${ }^{1} \mathrm{H}$ NMR (300 MHz, $\mathrm{CD}_{2} \mathrm{Cl}_{2}$ ) $\delta 95.46$ (b), 59.28 (s), 56.86 (s), 39.91 (b), 37.38 (s), 34.98 (s), 29.19 (s), 23.58 (s), 12.84 (s), 12.31 (s), 11.45 (s), 9.75 (s), -4.75 (s). ${ }^{19} \mathrm{~F}$ NMR (300 MHz, $\left.\mathrm{CD}_{2} \mathrm{Cl}_{2}\right) \delta$ $77.53(\mathrm{~s}),-60.10(\mathrm{~s})$. UV-Vis $\left(\mathrm{CH}_{2} \mathrm{Cl}_{2}\right)\left[\varepsilon\left(\mathrm{M}^{-1} \mathrm{~cm}^{-1}\right)\right]: 502 \mathrm{~nm}\left(4.05 \times 10^{3}\right)$. Anal. Calcd (\%) for $\mathrm{C}_{88} \mathrm{H}_{57} \mathrm{~F}_{12} \mathrm{Fe}_{4} \mathrm{~N}_{12} \mathrm{O}_{7} \mathrm{~S}: \mathrm{C}, 56.28 ; \mathrm{H}, 3.06 ; \mathrm{N}, 8.95$. Found: $\mathrm{C}, 56.33 ; \mathrm{H}, 3.58 ; \mathrm{N}, 8.98$.

$\left.\left[\mathbf{L F e}_{3} \mathbf{O}(\mathbf{P h I m})_{3} \mathbf{F e}\right]\left[\mathbf{B F}_{4}\right], \mathbf{( 2}^{\mathbf{H}}\right)$. A solution of $\left[\mathrm{Cp}_{2} \mathrm{Co}\right]\left[\mathrm{BF}_{4}\right](10.3 \mathrm{mg}, 0.037 \mathrm{mmol}, 1$ equiv.) in minimal acetonitrile was added to a suspension of freshly prepared [ $\left.\mathrm{LFe}_{3} \mathrm{O}(\mathrm{PhIm})_{3} \mathrm{Fe}\right]$ (108.8 $\mathrm{mg}, 0.071 \mathrm{mmol})$ in thawing tetrahydrofuran $(5 \mathrm{~mL})$. After stirring for one hour, the volatiles were removed under vacuum and the residue washed with diethyl ether to remove $\mathrm{Cp}_{2} \mathrm{Co}$, affording $\left[\mathrm{LFe}_{3} \mathrm{O}(\mathrm{PhIm})_{3} \mathrm{Fe}\right]\left[\mathrm{BF}_{4}\right]$ as a dark purple solid (102 $\mathrm{mg}, 89 \%$ yield). Crystals suitable for X-ray diffraction were obtained by diffusion of diethyl ether into a dilute solution of the compound in dichloromethane. ${ }^{1} \mathrm{H}$ NMR $\left(300 \mathrm{MHz}, \mathrm{CD}_{2} \mathrm{Cl}_{2}\right)$ : identical to that for $\left[\mathrm{LFe}_{3} \mathrm{O}(\mathrm{PhIm})_{3} \mathrm{Fe}\right][\mathrm{OTf}]\left(\right.$ 2-OTf). ${ }^{19} \mathrm{~F}$ NMR $\left(300 \mathrm{MHz}, \mathrm{CD}_{2} \mathrm{Cl}_{2}\right) \delta-151.70$.

$\left[\mathrm{LFe}_{3} \mathrm{O}\left({ }^{\mathrm{pNMe} 2} \mathrm{ArIm}\right)_{3} \mathrm{Fe}\right][\mathrm{OTf}],\left(\mathbf{2}^{\mathrm{NMe}}-\mathrm{OTf}\right)$. A solution of $\mathrm{Cp}^{*}{ }_{2} \mathrm{Co}(10.8 \mathrm{mg}, 0.033$ mmol, 1.0 equiv.) in $1 \mathrm{~mL}$ tetrahydrofuran was added dropwise to a stirring suspenion of $\left[\mathrm{LFe}_{3} \mathrm{O}\left({ }^{\mathrm{pNMe} 2} \mathrm{ArIm}\right)_{3} \mathrm{Fe}\right][\mathrm{OTf}]_{2}(63.9 \mathrm{mg}, 0.033 \mathrm{mmol}, 1.0$ equiv. $)$ in $4 \mathrm{~mL}$ of tetrahydrofuran. After stirring for four hours, the resulting black-purple precipitate was collected on a bed of Celite and eluted with 1,2-dimethoxyethane. The combined filtrates were concentrated to dryness under reduced pressure to afford $\left[\mathrm{LFe}_{3} \mathrm{O}\left({ }^{\mathrm{pNMe} 2} \mathrm{ArIm}\right)_{3} \mathrm{Fe}\right][\mathrm{OTf}]$ as a black-purple solid $(54 \mathrm{mg}, 91 \%$ yield). ${ }^{1} \mathrm{H}$ NMR (300 MHz, $\left.\mathrm{CD}_{2} \mathrm{Cl}_{2}\right) \delta 108.95$ (b), 57.97 (s), 43.61 (b), 40.23 (s), 37.57 (s), 35.13 (s), 25.44 (s), 14.68 (s), 13.33 (s), 12.41 (s), 10.90 (b), -4.94 (b). ${ }^{19} \mathrm{~F}$ NMR (300 MHz, $\left.\mathrm{CD}_{2} \mathrm{Cl}_{2}\right) \delta$ -78.95. UV-Vis $\left(\mathrm{CH}_{2} \mathrm{Cl}_{2}\right)\left[\varepsilon\left(\mathrm{M}^{-1} \mathrm{~cm}^{-1}\right)\right]: 566 \mathrm{~nm}\left(4.64 \times 10^{3}\right), 443 \mathrm{~nm}\left(5.60 \times 10^{3}\right)$. Anal. Calcd (\%) for $\mathrm{C}_{92} \mathrm{H}_{77} \mathrm{Cl}_{2} \mathrm{~F}_{3} \mathrm{Fe}_{4} \mathrm{~N}_{15} \mathrm{O}_{7} \mathrm{~S}$ : C, 58.53; H, 4.11; N, 11.83. Found: C, 58.75; H, 4.56; N, 11.30. 


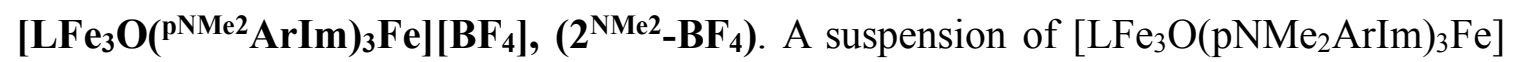
[OTf $]_{2}(126.5 \mathrm{mg}, 0.065 \mathrm{mmol}, 1$ equiv.) in $5 \mathrm{~mL}$ of tetahydrofuran was added to a suspension of $2 \% \mathrm{Na}(\mathrm{Hg})$ amalgam $(7.5 \mathrm{mg} \mathrm{Na}, 0.32 \mathrm{mmol}, 5$ equiv.) in $5 \mathrm{~mL}$ of tetrahydrofuran. After stirring for four hours, the suspension was decanted from the $\mathrm{Na}(\mathrm{Hg})$ amalgam and filtered through a fine frit. The metallic blue precipitate was washed with copious amounts of tetrahydrofuran, affording $\left[\mathrm{LFe}_{3} \mathrm{O}\left({ }^{\left({ }^{\mathrm{NMe}} 2\right.} \mathrm{ArIm}\right)_{3} \mathrm{Fe}\right](61.5 \mathrm{mg}, 0.037 \mathrm{mmol}, 57 \%$ yield $)$ which was used immediately without further purification.

A solution of $\left[\mathrm{Cp}_{2} \mathrm{Co}\right]\left[\mathrm{BF}_{4}\right](10.3 \mathrm{mg}, 0.037 \mathrm{mmol}, 1$ equiv. $)$ in minimal acetonitrile was added to a suspension of freshly prepared $\left[\mathrm{LFe}_{3} \mathrm{O}\left({ }^{\left({ }^{\mathrm{NMe}} 2\right.} \mathrm{ArIm}\right)_{3} \mathrm{Fe}\right](31.5 \mathrm{mg}, 0.021 \mathrm{mmol})$ in thawing tetrahydrofuran $(1 \mathrm{~mL})$. After stirring for one hour, the volatiles were removed under vacuum and the residue washed with diethyl ether to remove $\mathrm{Cp}_{2} \mathrm{Co}$, affording $\left[\mathrm{LFe}_{3} \mathrm{O}\left({ }^{\left({ }^{\mathrm{NMe} 2}\right.} \mathrm{ArIm}\right)_{3} \mathrm{Fe}\right]\left[\mathrm{BF}_{4}\right]$ as a black-purple solid $(59 \mathrm{mg}, 92 \%$ yield). Crystals suitable for $\mathrm{X}-$ ray diffraction were obtained by diffusion of diethyl ether into a dilute solution of the compound in dichloromethane. ${ }^{1} \mathrm{H} \quad \mathrm{NMR} \quad\left(300 \mathrm{MHz}, \mathrm{CD}_{2} \mathrm{Cl}_{2}\right)$ : identical to that for $\left[\mathrm{LFe}_{3} \mathrm{O}\left({ }^{\mathrm{pNMe} 2} \mathrm{ArIm}\right){ }_{3} \mathrm{Fe}\right][\mathrm{OTf}]\left(2^{\mathrm{NMe} 2}-\mathrm{OTf}\right) .{ }^{19} \mathrm{~F}$ NMR $\left(300 \mathrm{MHz}, \mathrm{CD}_{2} \mathrm{Cl}_{2}\right) \delta-152.91$. 


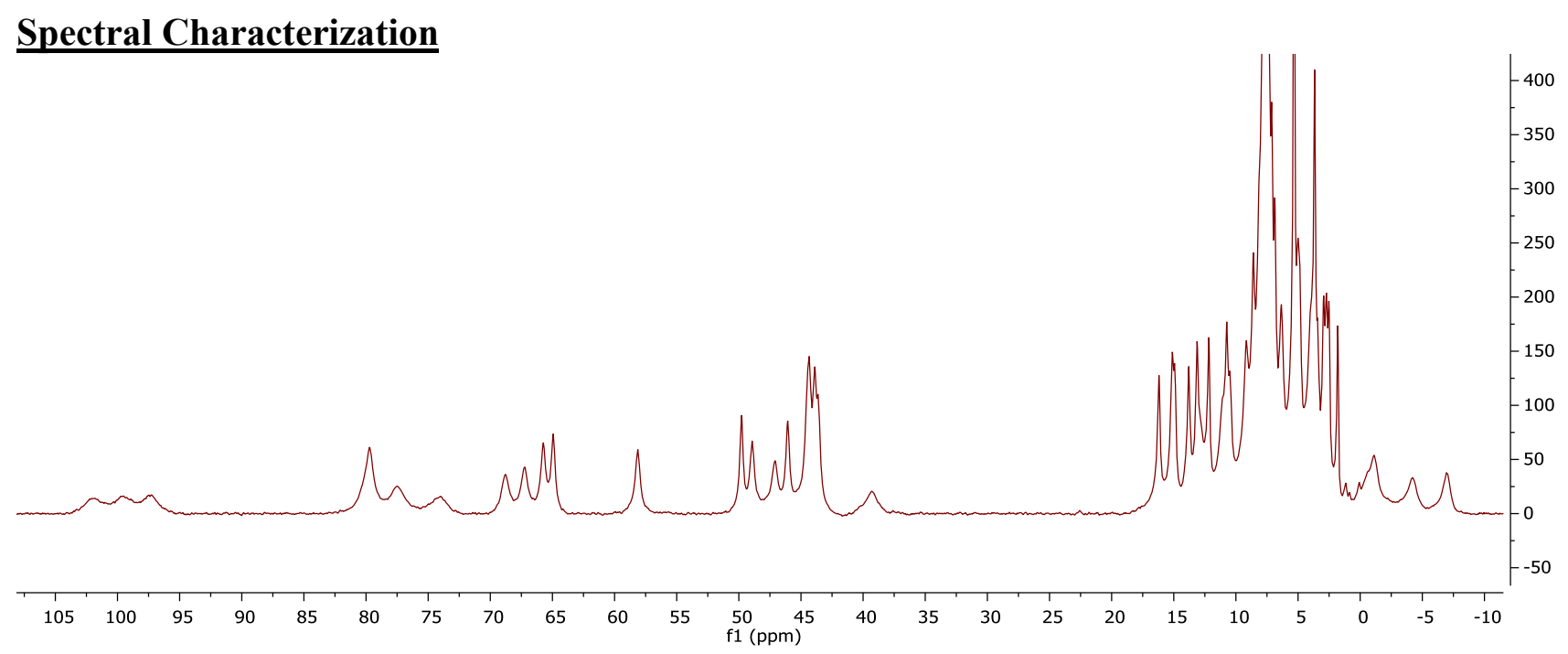

Figure S1. ${ }^{1} \mathrm{H}$ NMR $(300 \mathrm{MHz})$ of $\left[\mathrm{LFe}_{3} \mathrm{O}\left({ }^{\mathrm{pCF}} \mathrm{ArIm}-\mathrm{H}\right)_{3}\right][\mathrm{OTf}]_{3}(\mathbf{A})$ in $\mathrm{CD}_{2} \mathrm{Cl}_{2}$

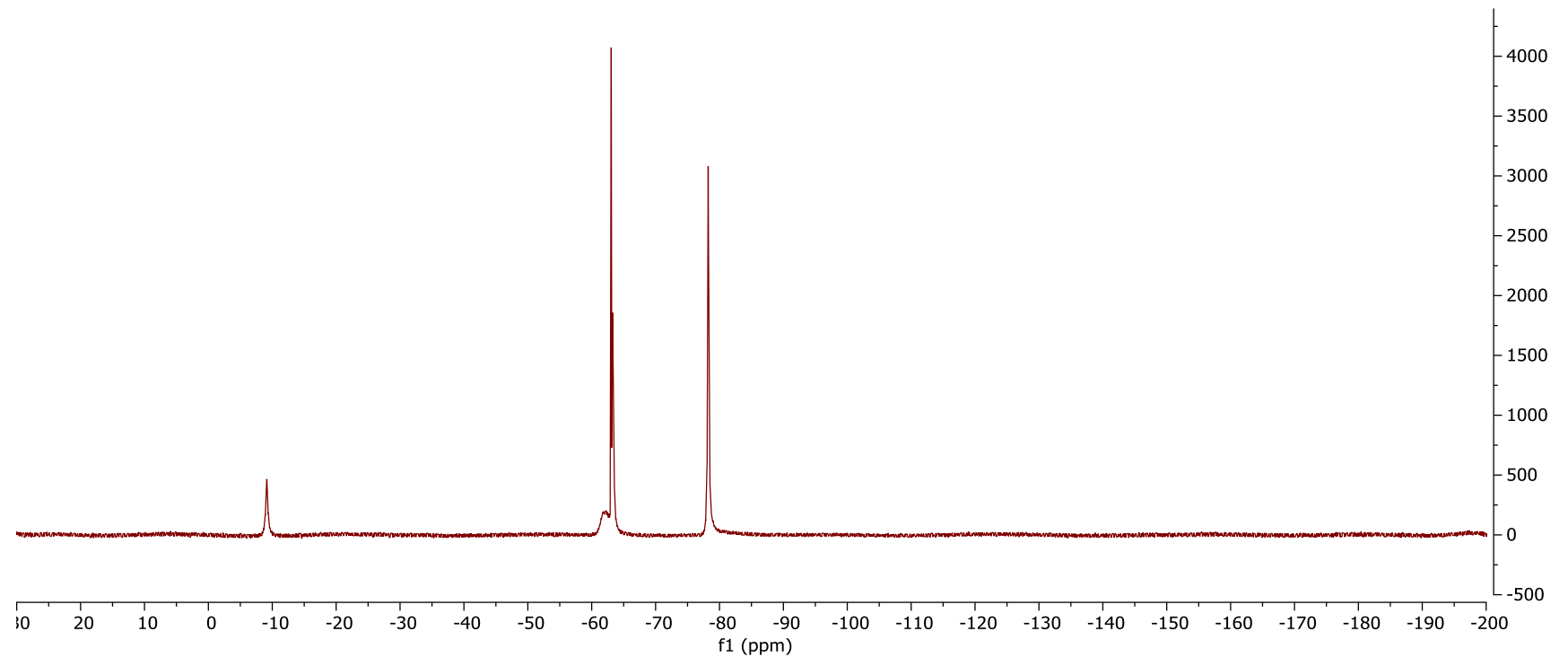

Figure S2. ${ }^{19} \mathrm{~F}$ NMR $(300 \mathrm{MHz})$ of $\left[\mathrm{LFe}_{3} \mathrm{O}\left({ }^{\mathrm{pCF} 3} \mathrm{ArIm}-\mathrm{H}\right)_{3}\right][\mathrm{OTf}]_{3}(\mathbf{A})$ in $\mathrm{CD}_{2} \mathrm{Cl}_{2}$ 


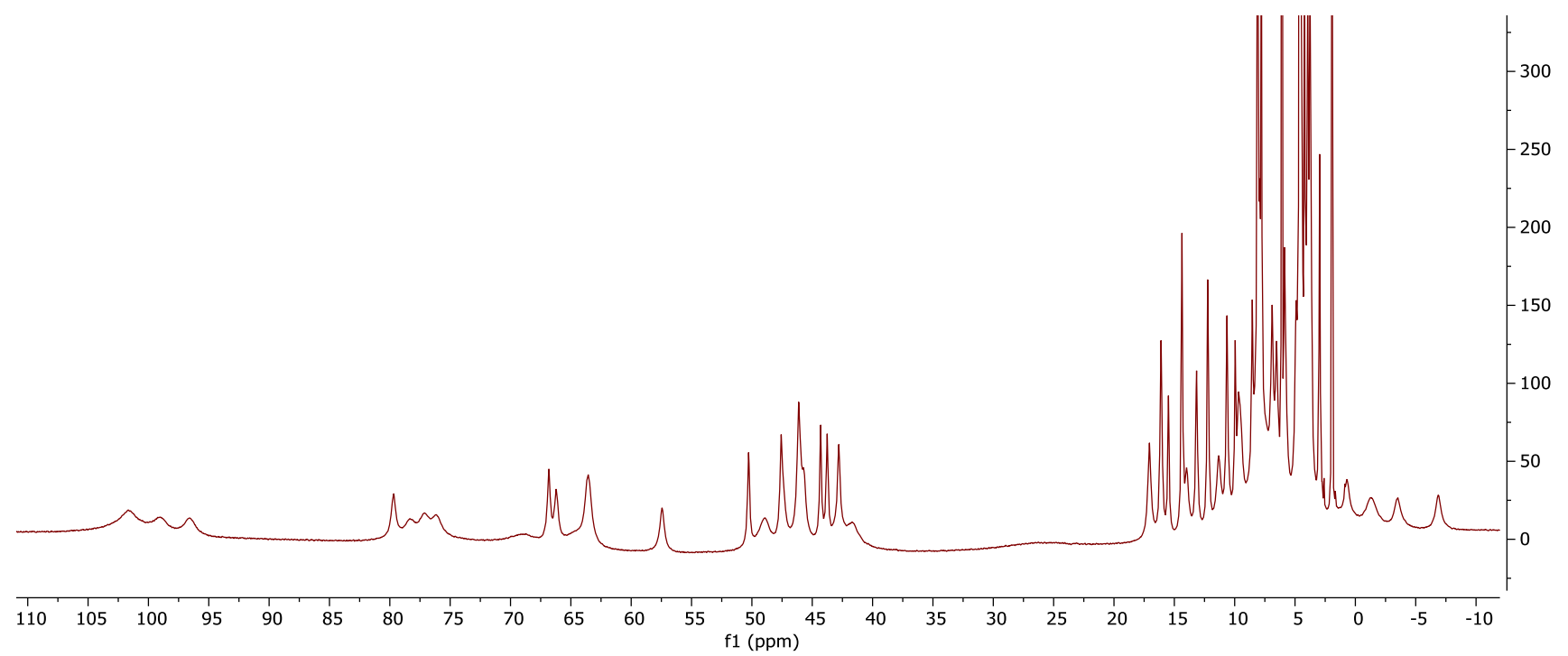

Figure S3. ${ }^{1} \mathrm{H}$ NMR $(300 \mathrm{MHz})$ of $\left[\mathrm{LFe}_{3} \mathrm{O}\left({ }^{\mathrm{pOMe}} \mathrm{ArIm}-\mathrm{H}\right)_{3}\right][\mathrm{OTf}]_{3}$ (B) in $\mathrm{CD}_{2} \mathrm{Cl}_{2}$

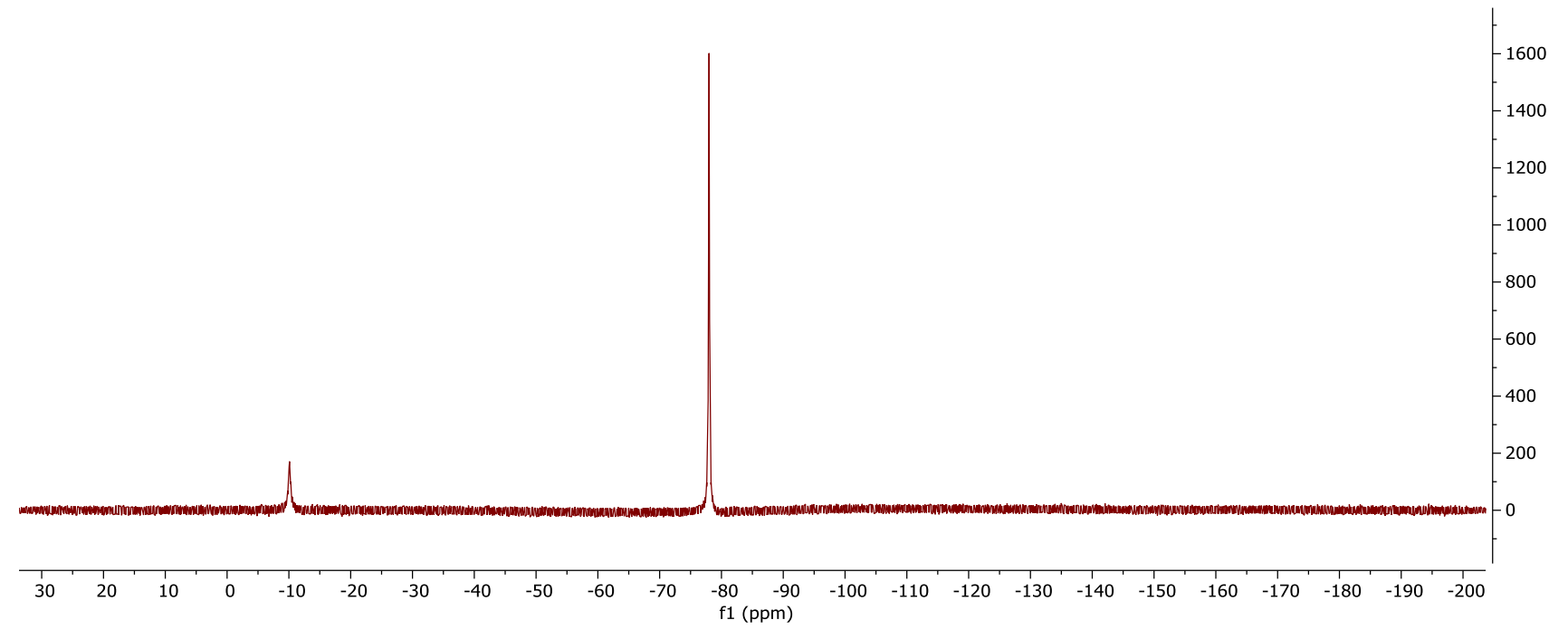

Figure S4. ${ }^{19} \mathrm{~F}$ NMR $(300 \mathrm{MHz})$ of $\left[\mathrm{LFe}_{3} \mathrm{O}\left({ }^{\mathrm{pOMe}} \mathrm{ArIm}-\mathrm{H}\right)_{3}\right][\mathrm{OTf}]_{3}(\mathbf{B})$ in $\mathrm{CD}_{2} \mathrm{Cl}_{2}$ 


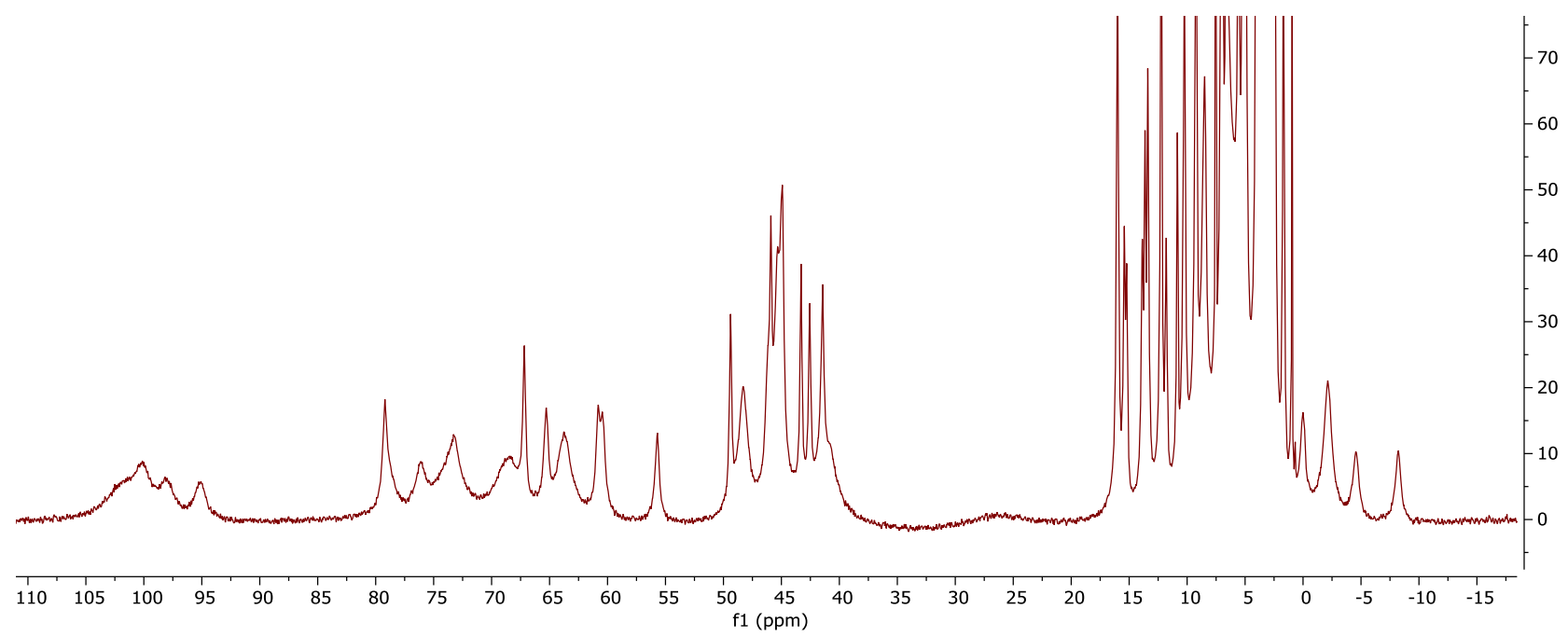

Figure S5. ${ }^{1} \mathrm{H} \mathrm{NMR}(300 \mathrm{MHz})$ of $\left[\mathrm{LFe}_{3} \mathrm{O}\left({ }^{\mathrm{pNMe} 2} \mathrm{ArIm}-\mathrm{H}\right)_{3}\right][\mathrm{OTf}]_{3}(\mathbf{C})$ in $\mathrm{CD}_{2} \mathrm{Cl}_{2}$

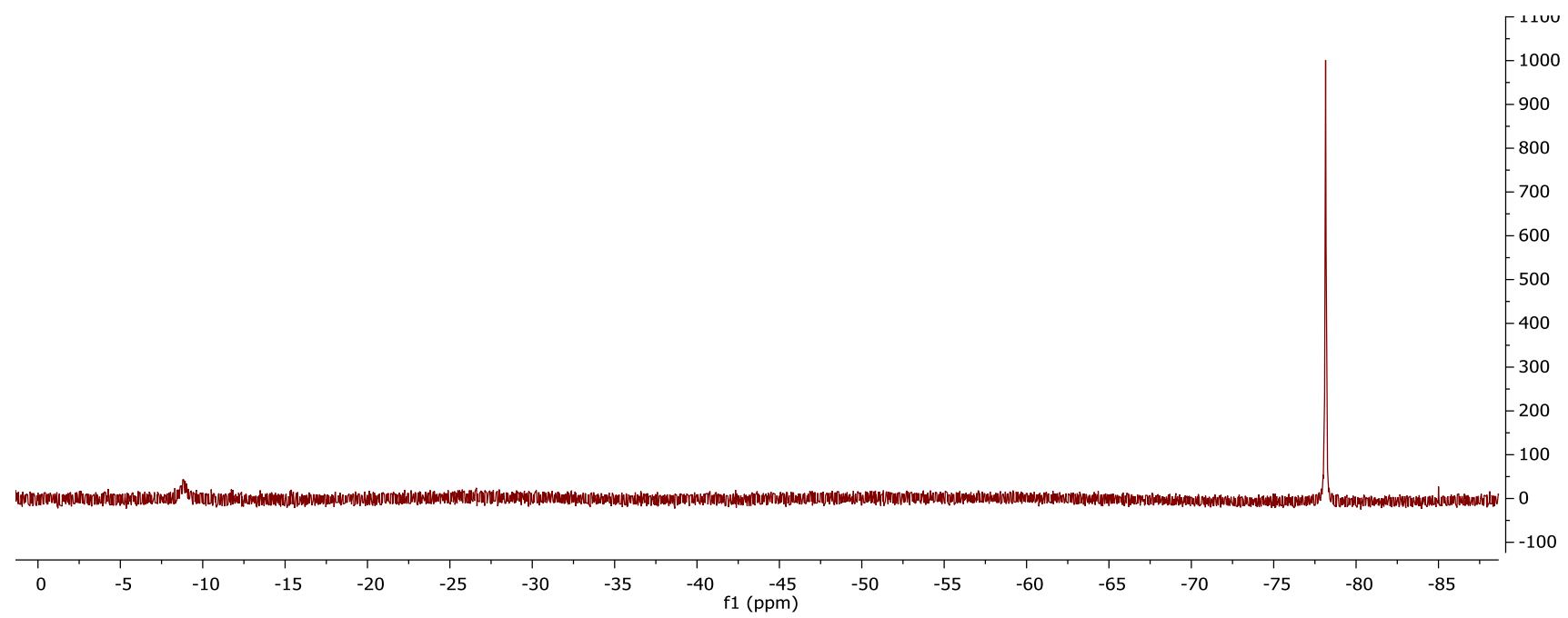

Figure S6. ${ }^{19} \mathrm{~F}$ NMR $(300 \mathrm{MHz})$ of $\left[\mathrm{LFe}_{3} \mathrm{O}\left({ }^{\mathrm{pNMe} 2} \mathrm{ArIm}-\mathrm{H}\right)_{3}\right][\mathrm{OTf}]_{3}(\mathbf{C})$ in $\mathrm{CD}_{2} \mathrm{Cl}_{2}$

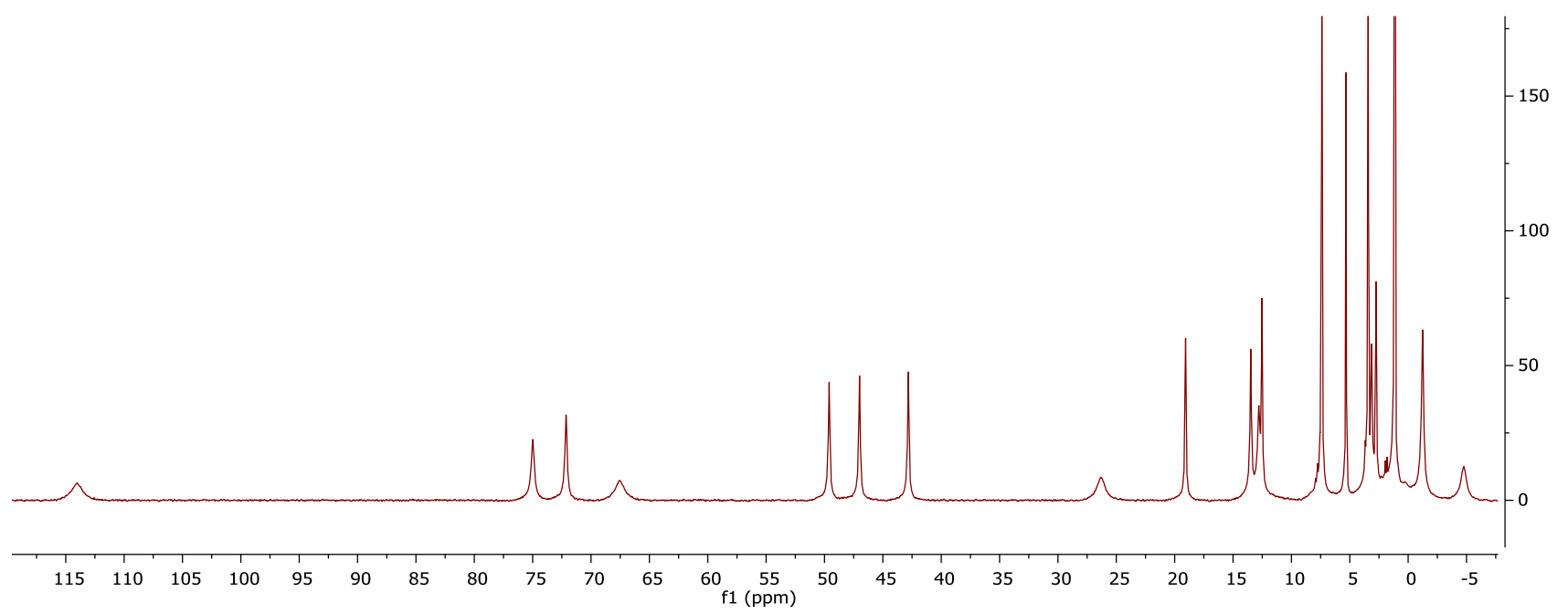

Figure S7. ${ }^{1} \mathrm{H}$ NMR $(300 \mathrm{MHz})$ of $\left[\mathrm{LFe}_{3} \mathrm{O}\left({ }^{\mathrm{pCF} 3} \mathrm{ArIm}\right){ }_{3} \mathrm{Fe}\right][\mathrm{OTf}]_{2}\left(\mathbf{1}^{\mathrm{CF}}\right)$ in $\mathrm{CD}_{2} \mathrm{Cl}_{2}$ 


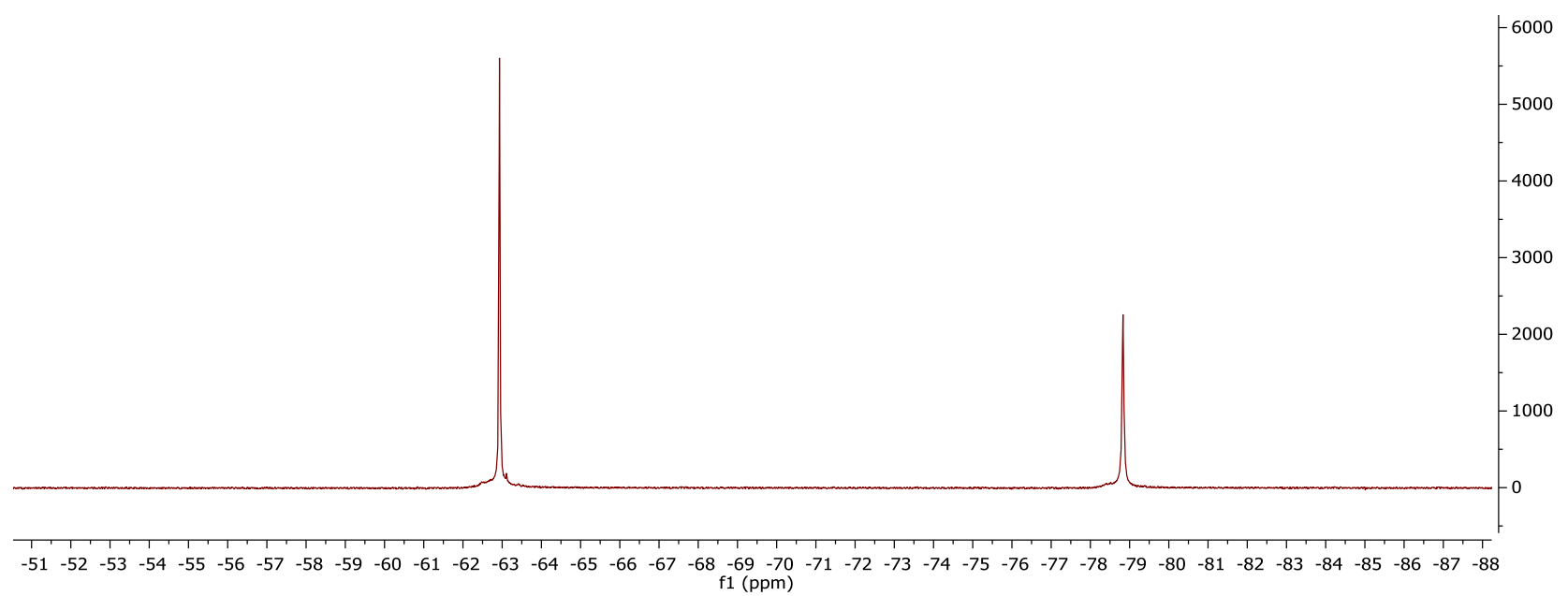

Figure S8. ${ }^{19} \mathrm{~F}$ NMR $(300 \mathrm{MHz})$ of $\left[\mathrm{LFe}_{3} \mathrm{O}\left({ }^{\mathrm{pCF} 3} \mathrm{ArIm}\right){ }_{3} \mathrm{Fe}\right][\mathrm{OTf}]_{2}\left(\mathbf{1}^{\mathbf{C F} 3}\right)$ in $\mathrm{CD}_{2} \mathrm{Cl}_{2}$

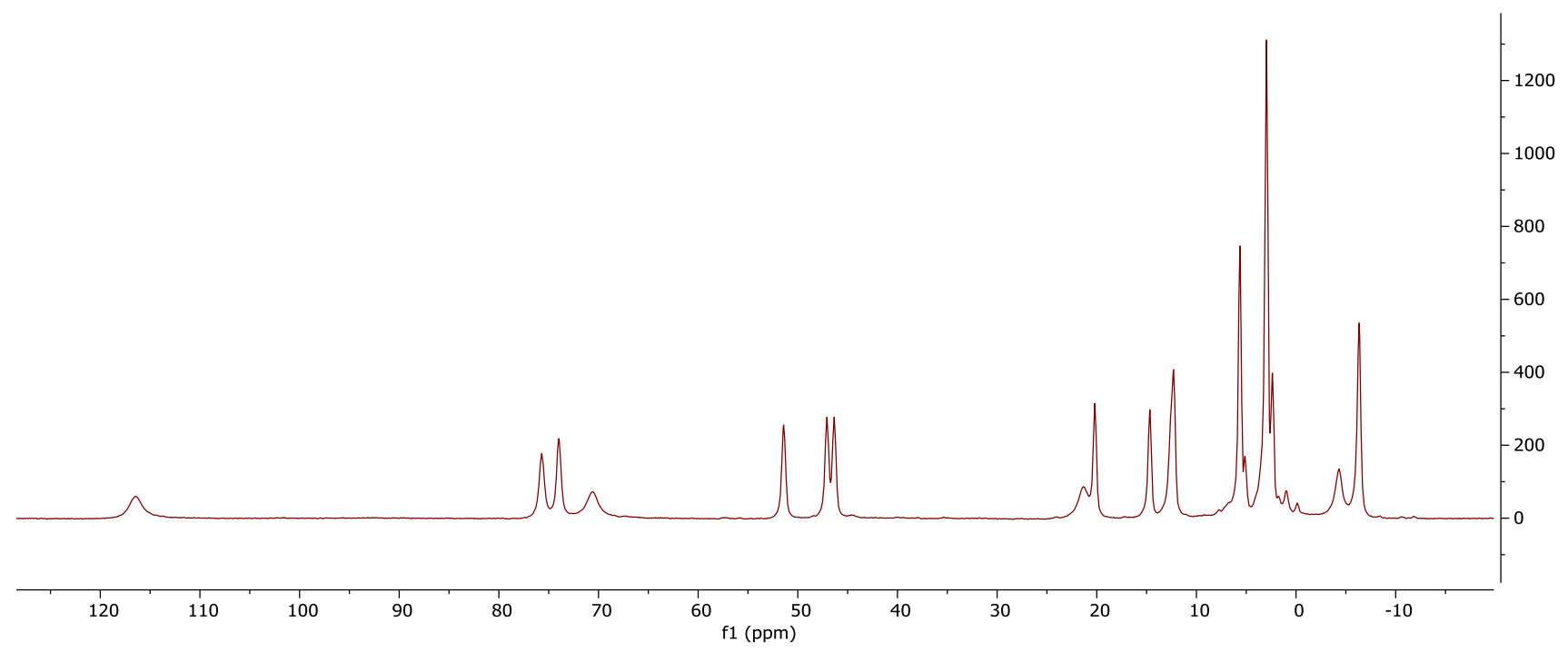

Figure S9. ${ }^{1} \mathrm{H}$ NMR $(300 \mathrm{MHz})$ of $\left[\mathrm{LFe}_{3} \mathrm{O}\left({ }^{\mathrm{pOMe}} \mathrm{ArIm}\right){ }_{3} \mathrm{Fe}\right][\mathrm{OTf}]_{2}\left(\mathbf{1}^{\mathbf{O M e}}\right)$ in $\mathrm{CD}_{2} \mathrm{Cl}_{2}$

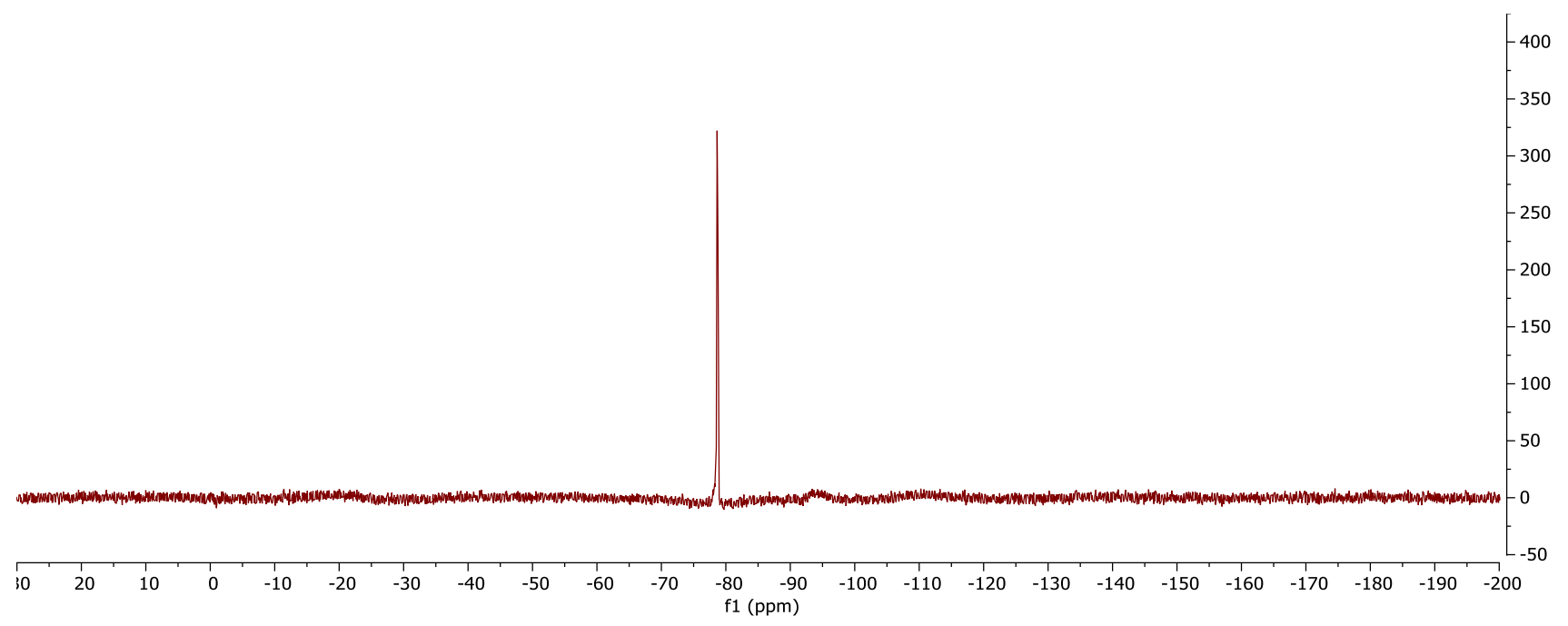

Figure S10. ${ }^{19} \mathrm{~F}$ NMR $(300 \mathrm{MHz})$ of $\left[\mathrm{LFe}_{3} \mathrm{O}\left({ }^{\mathrm{pOMe}} \mathrm{ArIm}\right){ }_{3} \mathrm{Fe}\right][\mathrm{OTf}]_{2}\left(\mathbf{1}^{\text {OMe }}\right)$ in $\mathrm{CD}_{2} \mathrm{Cl}_{2}$ 


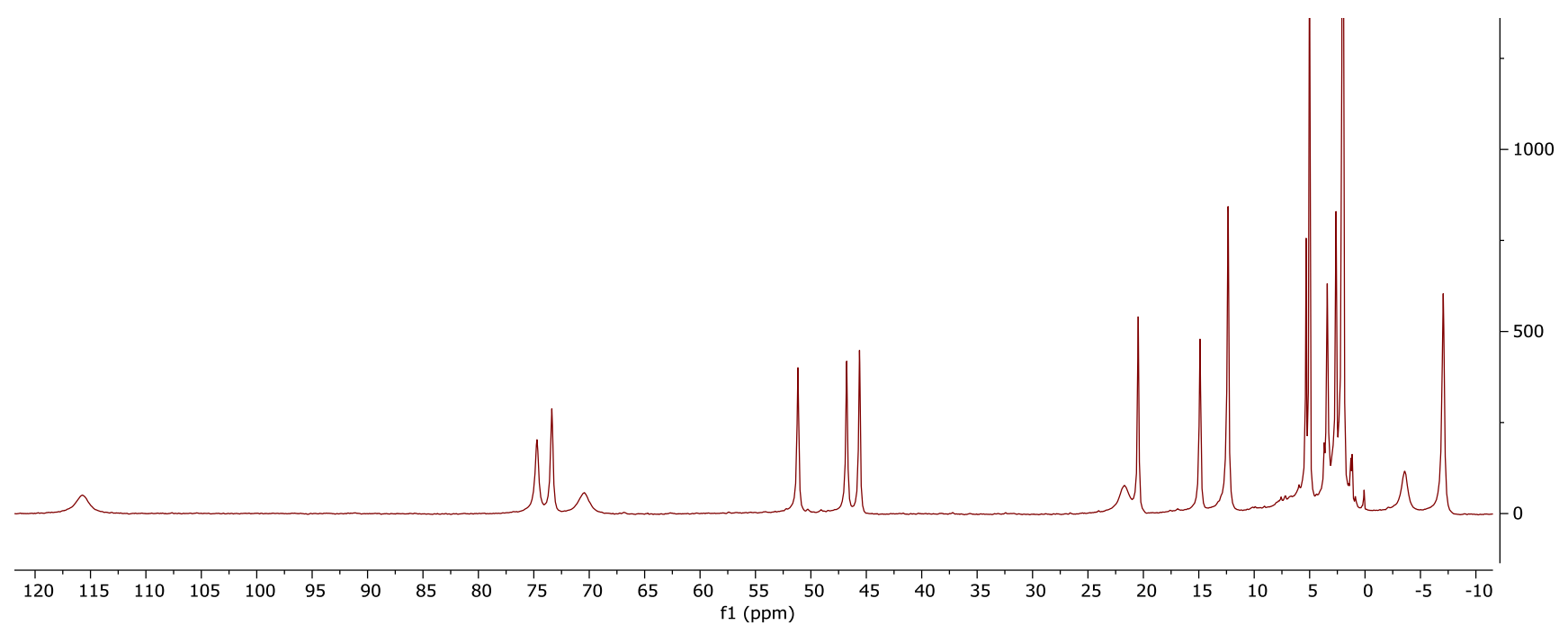

Figure S11. ${ }^{1} \mathrm{H}$ NMR $(300 \mathrm{MHz})$ of $\left[\mathrm{LFe}_{3} \mathrm{O}\left({ }^{\mathrm{pNMe} 2} \mathrm{ArIm}\right)_{3} \mathrm{Fe}\right][\mathrm{OTf}]_{2}\left(\mathbf{1}^{\mathrm{NMe}}\right)$ in $\mathrm{CD}_{2} \mathrm{Cl}_{2}$

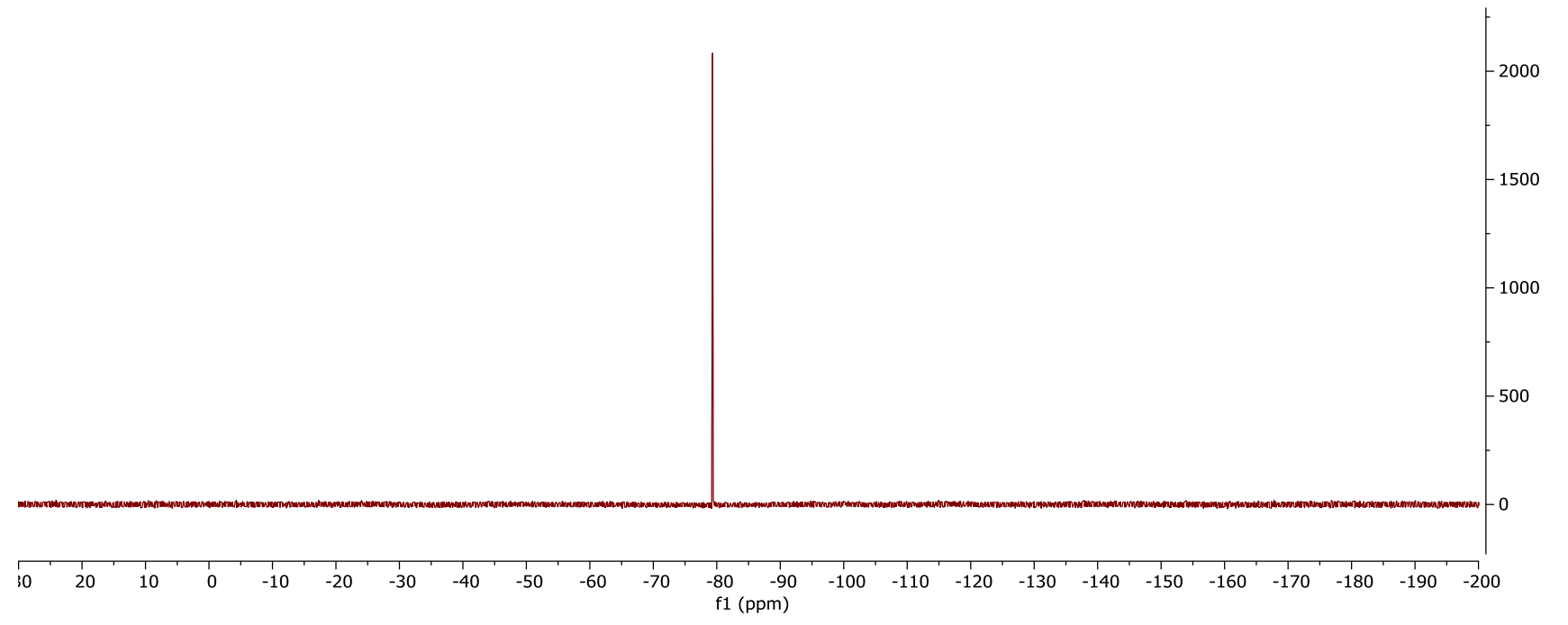

Figure S12. ${ }^{19} \mathrm{~F}$ NMR $(300 \mathrm{MHz})$ of $\left[\mathrm{LFe}_{3} \mathrm{O}\left({ }^{\mathrm{pNMe} 2} \mathrm{ArIm}\right){ }_{3} \mathrm{Fe}\right][\mathrm{OTf}]_{2}\left(\mathbf{1}^{\mathrm{NMe} 2}\right)$ in $\mathrm{CD}_{2} \mathrm{Cl}_{2}$ 


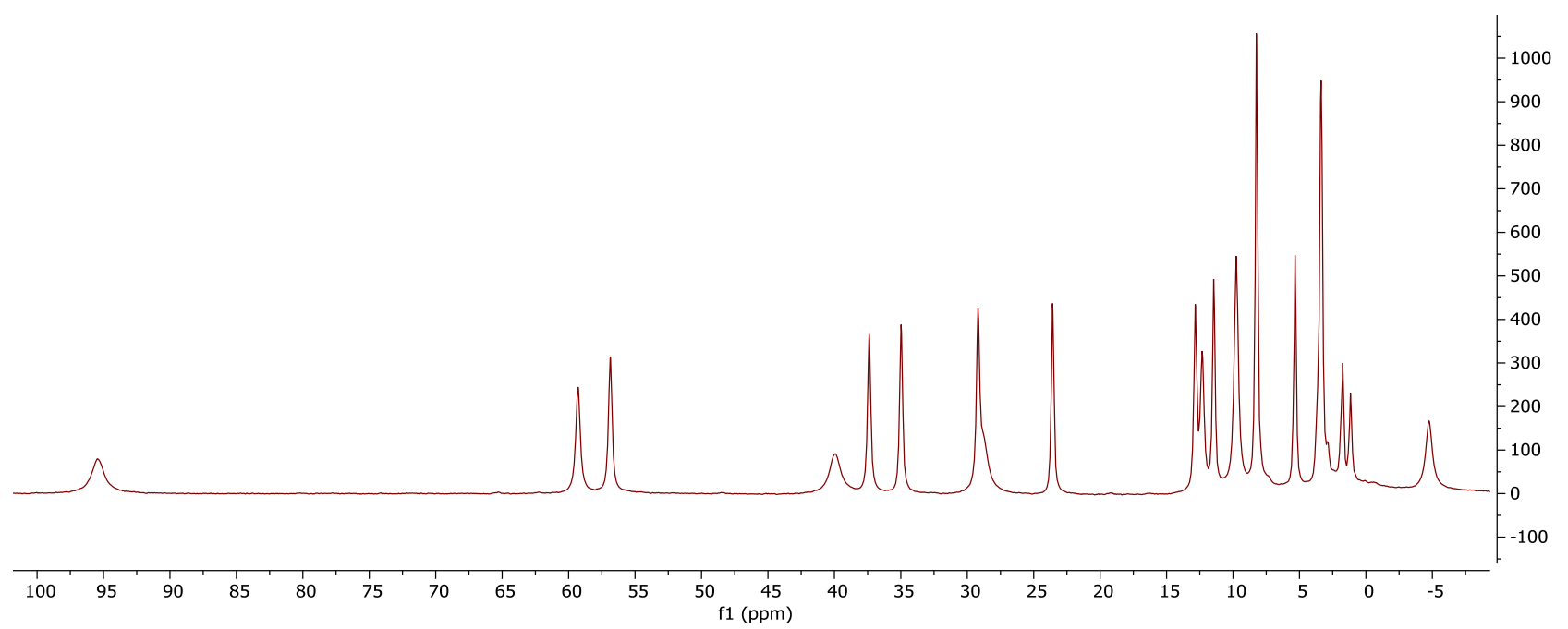

Figure S13. ${ }^{1} \mathrm{H} \mathrm{NMR}(300 \mathrm{MHz})$ of $\left[\mathrm{LFe}_{3} \mathrm{O}\left({ }^{\mathrm{pCF}} \mathrm{ArIm}\right){ }_{3} \mathrm{Fe}\right][\mathrm{OTf}]\left(\mathbf{2}^{\mathbf{C F} 3}\right)$ in $\mathrm{CD}_{2} \mathrm{Cl}_{2}$

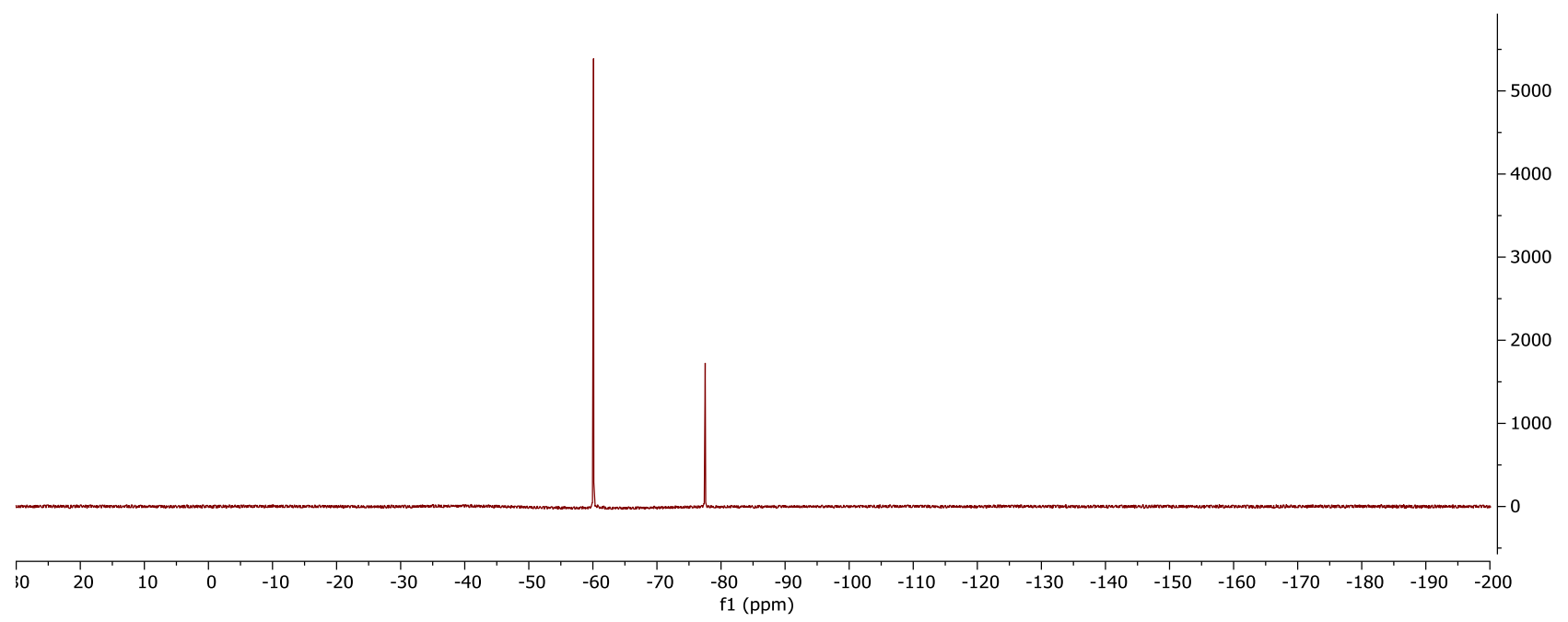

Figure S14. ${ }^{19} \mathrm{~F}$ NMR $(300 \mathrm{MHz})$ of $\left[\mathrm{LFe}_{3} \mathrm{O}\left({ }^{\mathrm{pCF} 3} \mathrm{ArIm}\right){ }_{3} \mathrm{Fe}\right][\mathrm{OTf}]\left(2^{\mathrm{CF} 3}\right)$ in $\mathrm{CD}_{2} \mathrm{Cl}_{2}$

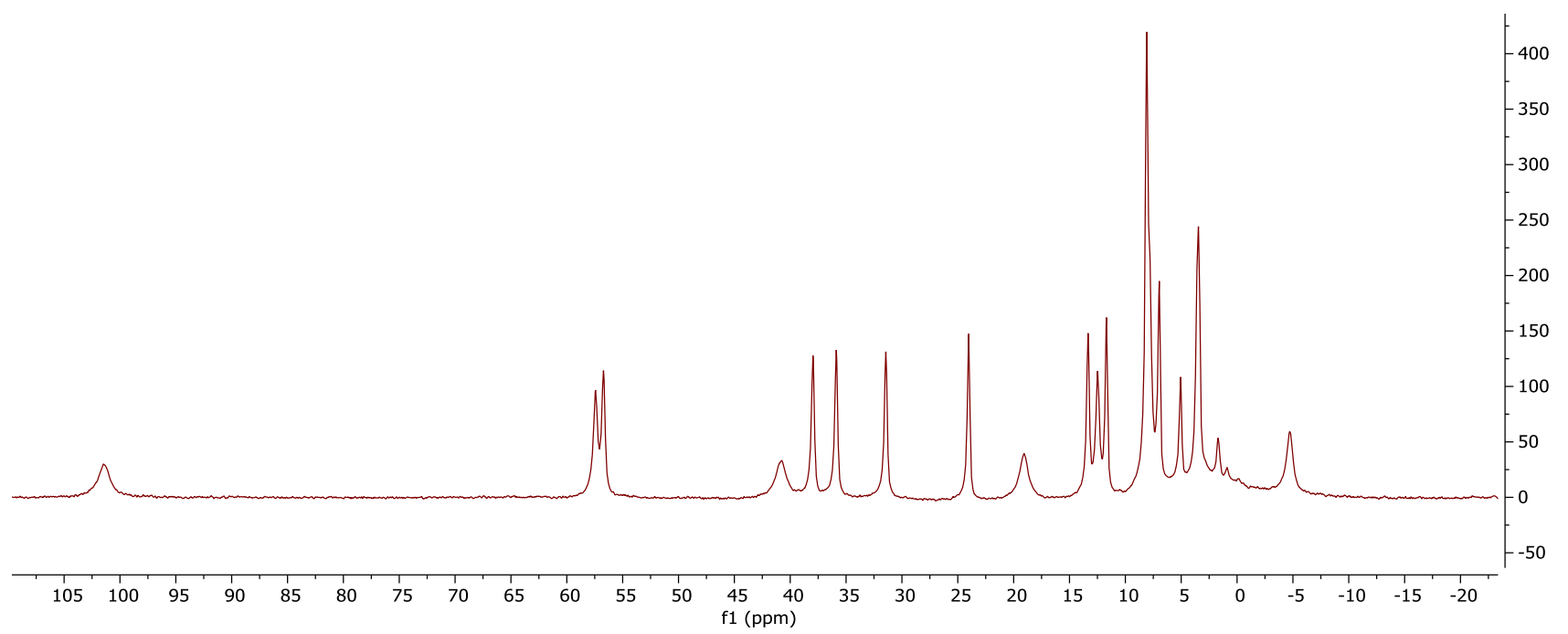


Figure S15. ${ }^{1} \mathrm{H}$ NMR $(300 \mathrm{MHz})$ of $\left[\mathrm{LFe}_{3} \mathrm{O}(\mathrm{PhIm})_{3} \mathrm{Fe}\right]\left[\mathrm{BF}_{4}\right]\left(2^{\mathrm{H}}\right)$ in $\mathrm{CD}_{2} \mathrm{Cl}_{2}$

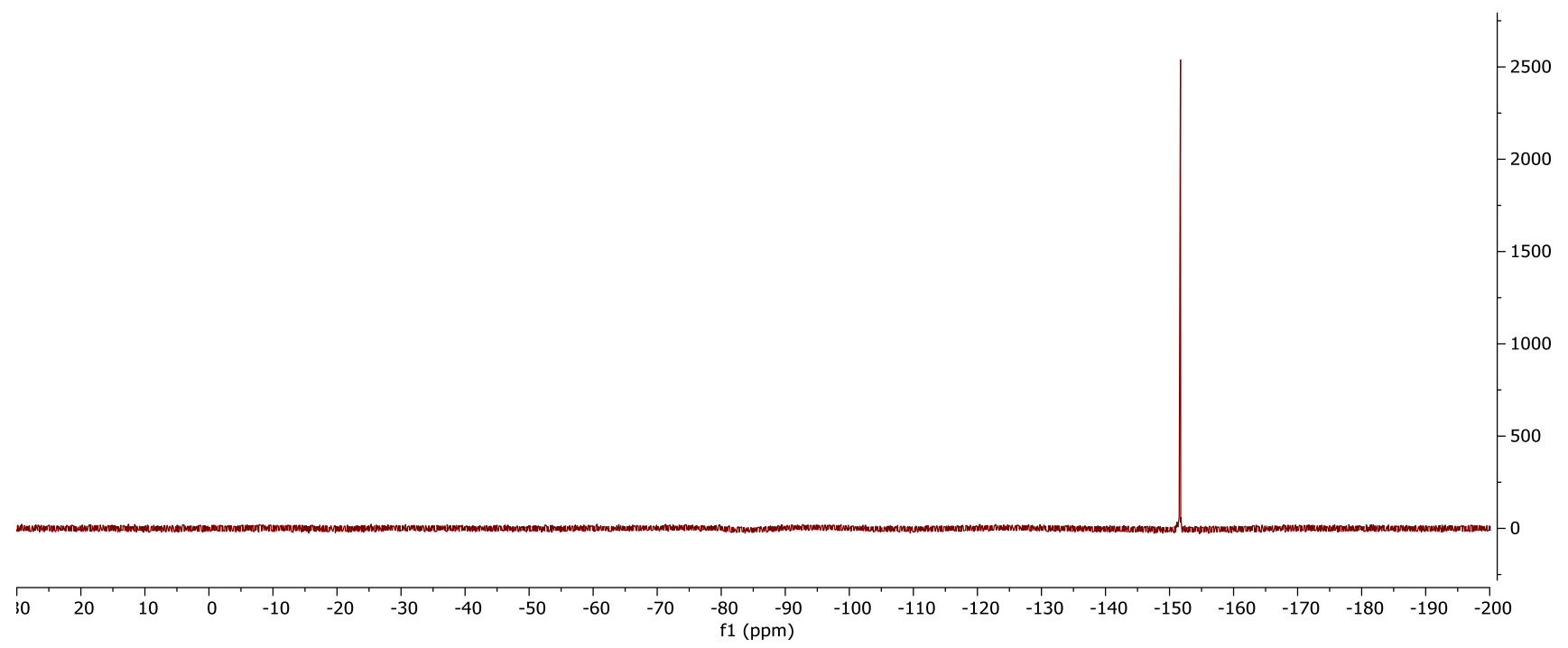

Figure S16. ${ }^{19} \mathrm{~F}$ NMR $(300 \mathrm{MHz})$ of $\left[\mathrm{LFe}_{3} \mathrm{O}(\mathrm{PhIm})_{3} \mathrm{Fe}\right]\left[\mathrm{BF}_{4}\right]\left(\mathbf{2}^{\mathbf{H}}\right)$ in $\mathrm{CD}_{2} \mathrm{Cl}_{2}$

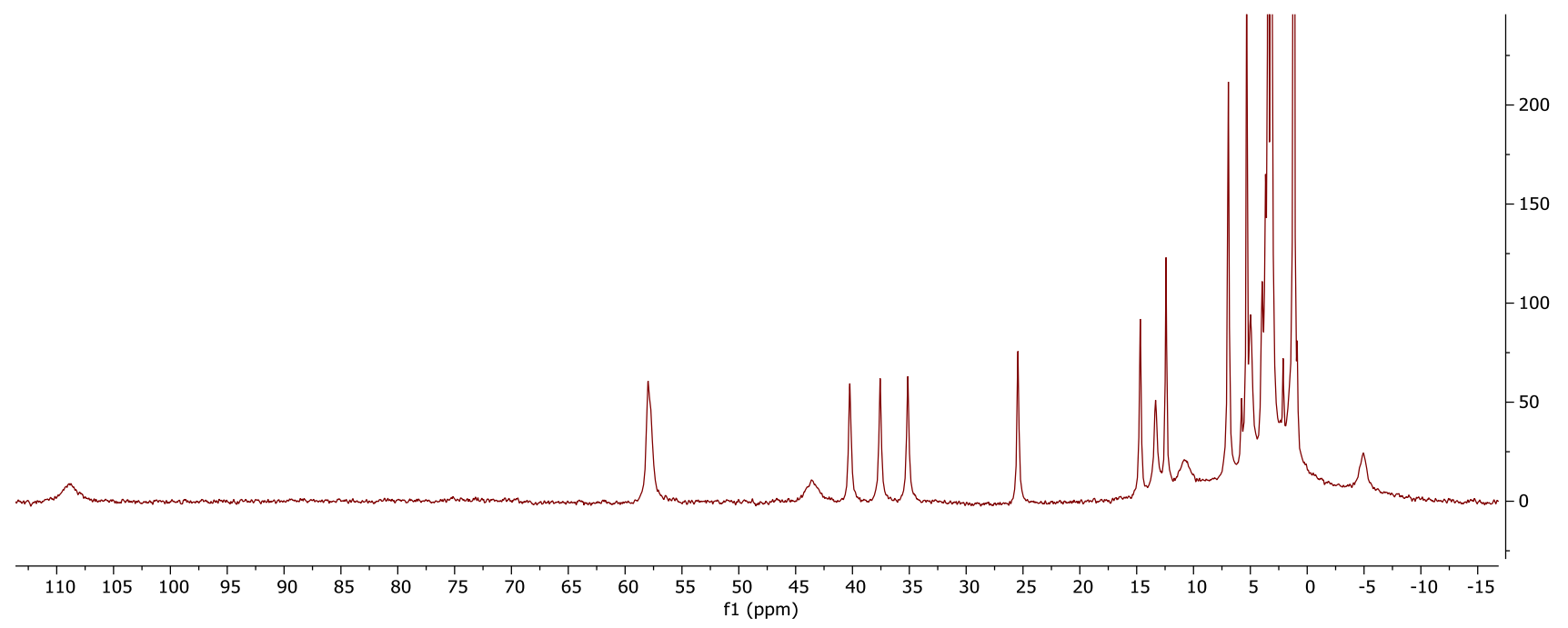

Figure S17. ${ }^{1} \mathrm{H}$ NMR $(300 \mathrm{MHz})$ of $\left[\mathrm{LFe}_{3} \mathrm{O}\left({ }^{\mathrm{pNMe} 2} \mathrm{ArIm}\right){ }_{3} \mathrm{Fe}\right][\mathrm{OTf}]\left(\mathbf{2}^{\text {NMe2}}-\mathbf{O T f}\right)$ in $\mathrm{CD}_{2} \mathrm{Cl}_{2}$ 


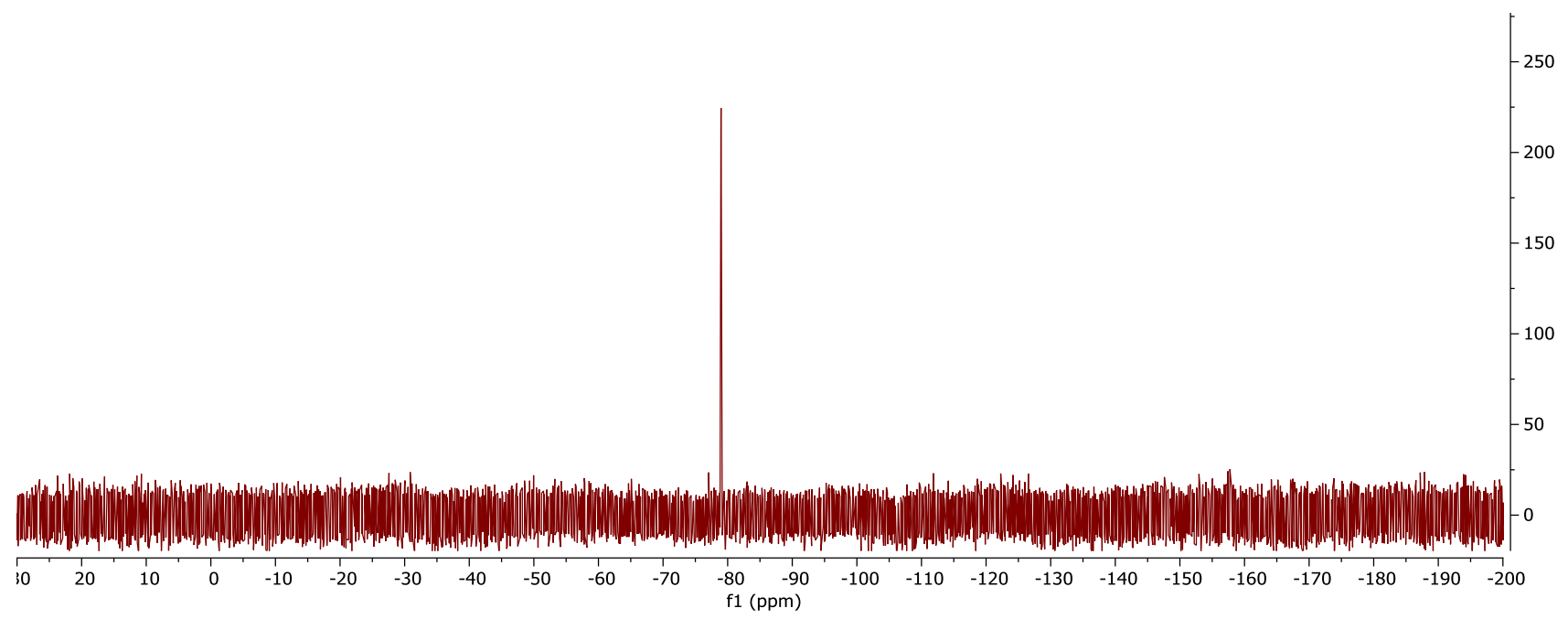

Figure S18. ${ }^{19} \mathrm{~F}$ NMR $(300 \mathrm{MHz})$ of $\left[\mathrm{LFe}_{3} \mathrm{O}\left({ }^{\mathrm{pNMe} 2} \mathrm{ArIm}\right){ }_{3} \mathrm{Fe}\right][\mathrm{OTf}]\left(\mathbf{2}^{\mathrm{NMe}}-\mathrm{OTf}\right)$ in $\mathrm{CD}_{2} \mathrm{Cl}_{2}$

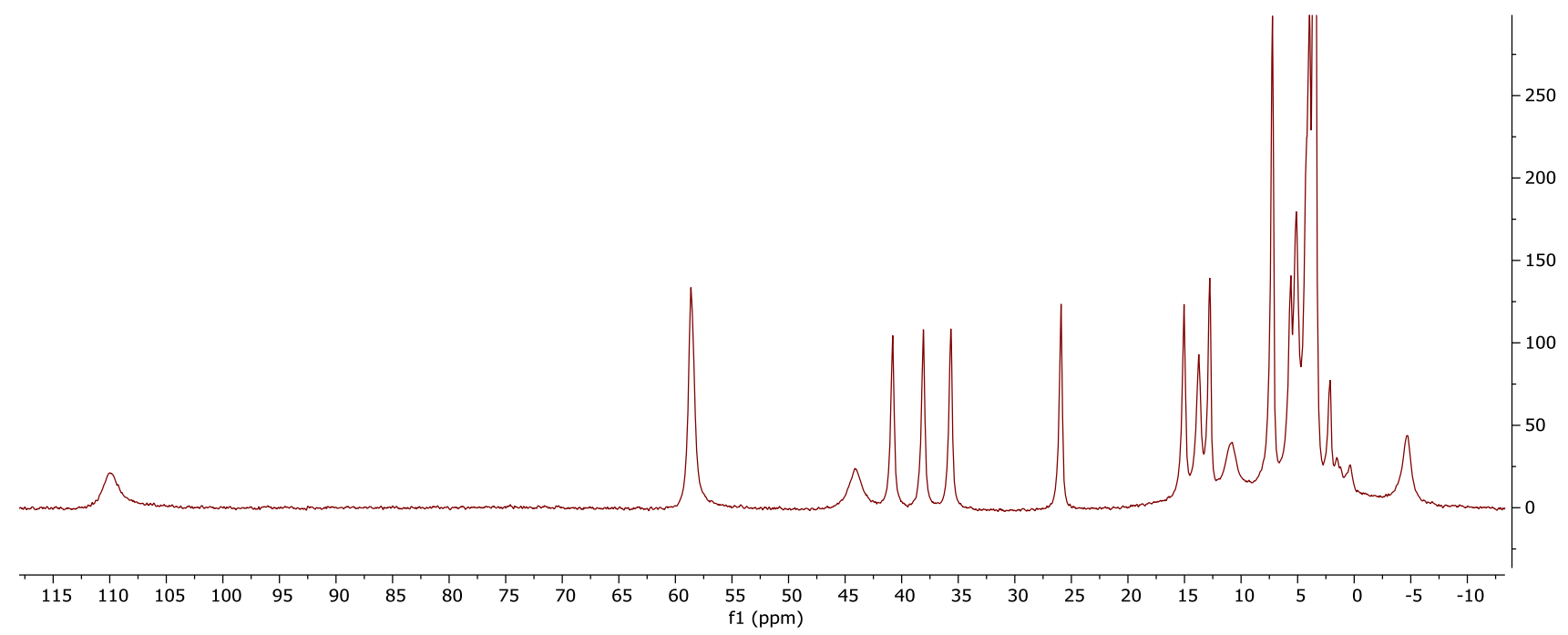

Figure S19. ${ }^{1} \mathrm{H}$ NMR $(300 \mathrm{MHz})$ of $\left[\mathrm{LFe}_{3} \mathrm{O}\left({ }^{\mathrm{pNMe} 2} \mathrm{ArIm}\right){ }_{3} \mathrm{Fe}\right]\left[\mathrm{BF}_{4}\right]\left(\mathbf{2}^{\mathbf{N M e}^{2}}-\mathbf{B F}_{4}\right)$ in $\mathrm{CD}_{2} \mathrm{Cl}_{2}$ 


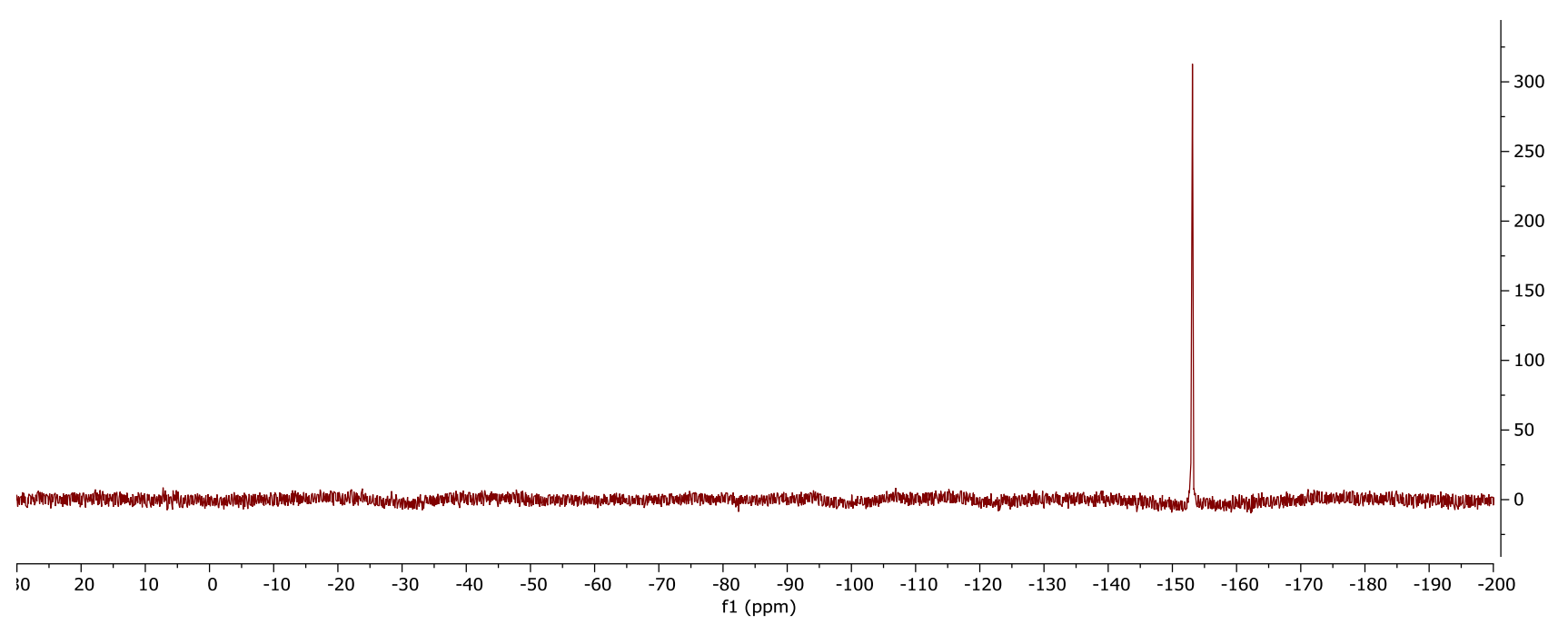

Figure S20. ${ }^{19} \mathrm{~F}$ NMR $(300 \mathrm{MHz})$ of $\left[\mathrm{LFe}_{3} \mathrm{O}\left({ }^{\mathrm{pNMe} 2} \mathrm{ArIm}\right){ }_{3} \mathrm{Fe}\right]\left[\mathrm{BF}_{4}\right]\left(\mathbf{2}^{\mathrm{NMe}^{2}}-\mathbf{B F}_{4}\right)$ in $\mathrm{CD}_{2} \mathrm{Cl}_{2}$

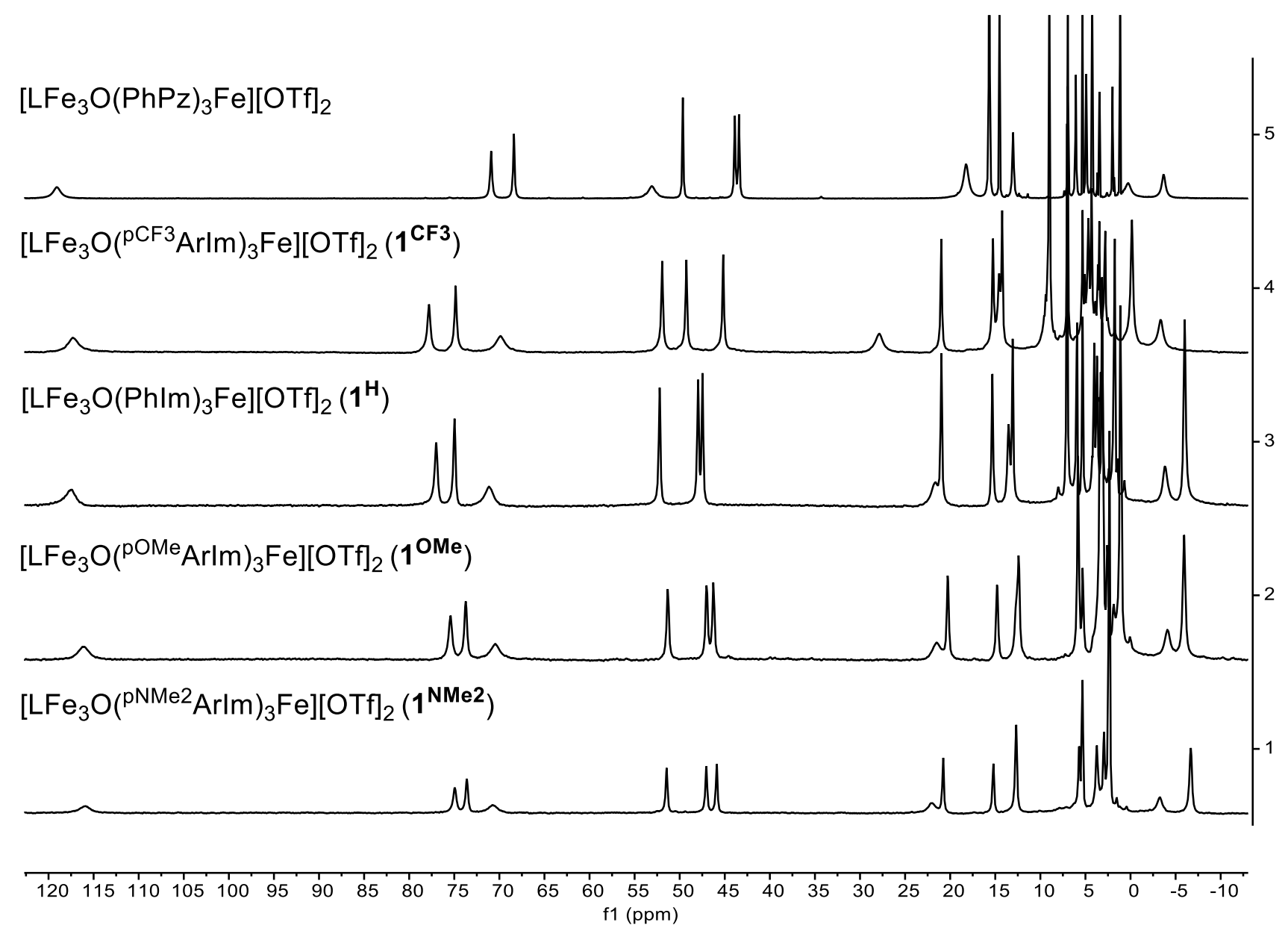

Figure S21. Comparison of ${ }^{1} \mathrm{H} \quad \mathrm{NMR} \quad(300 \mathrm{MHz})$ of $\left[\mathrm{LFe}_{3} \mathrm{O}(\mathrm{PhPz})_{3} \mathrm{Fe}\right][\mathrm{OTf}]_{2}$, $\left[\mathrm{LFe}_{3} \mathrm{O}\left({ }^{\mathrm{pCF}} \mathrm{ArIm}\right)_{3} \mathrm{Fe}\right][\mathrm{OTf}]_{2}\left(\mathbf{1}^{\mathbf{C F} 3}\right),\left[\mathrm{LFe}{ }_{3} \mathrm{O}(\mathrm{PhIm})_{3} \mathrm{Fe}\right][\mathrm{OTf}]_{2}\left(\mathbf{1}^{\mathbf{H}}\right),\left[\mathrm{LFe}_{3} \mathrm{O}\left({ }^{\text {pOMe }} \mathrm{ArIm}\right){ }_{3} \mathrm{Fe}\right][\mathrm{OTf}]_{2}$ $\left(\mathbf{1}^{\mathrm{OMe}}\right)$, and $\left[\mathrm{LFe}_{3} \mathrm{O}\left({ }^{\mathrm{pNMe} 2} \mathrm{ArIm}\right)_{3} \mathrm{Fe}\right][\mathrm{OTf}]_{2}\left(\mathbf{1}^{\mathrm{NMe} 2}\right)$ in $\mathrm{CD}_{2} \mathrm{Cl}_{2}$ 


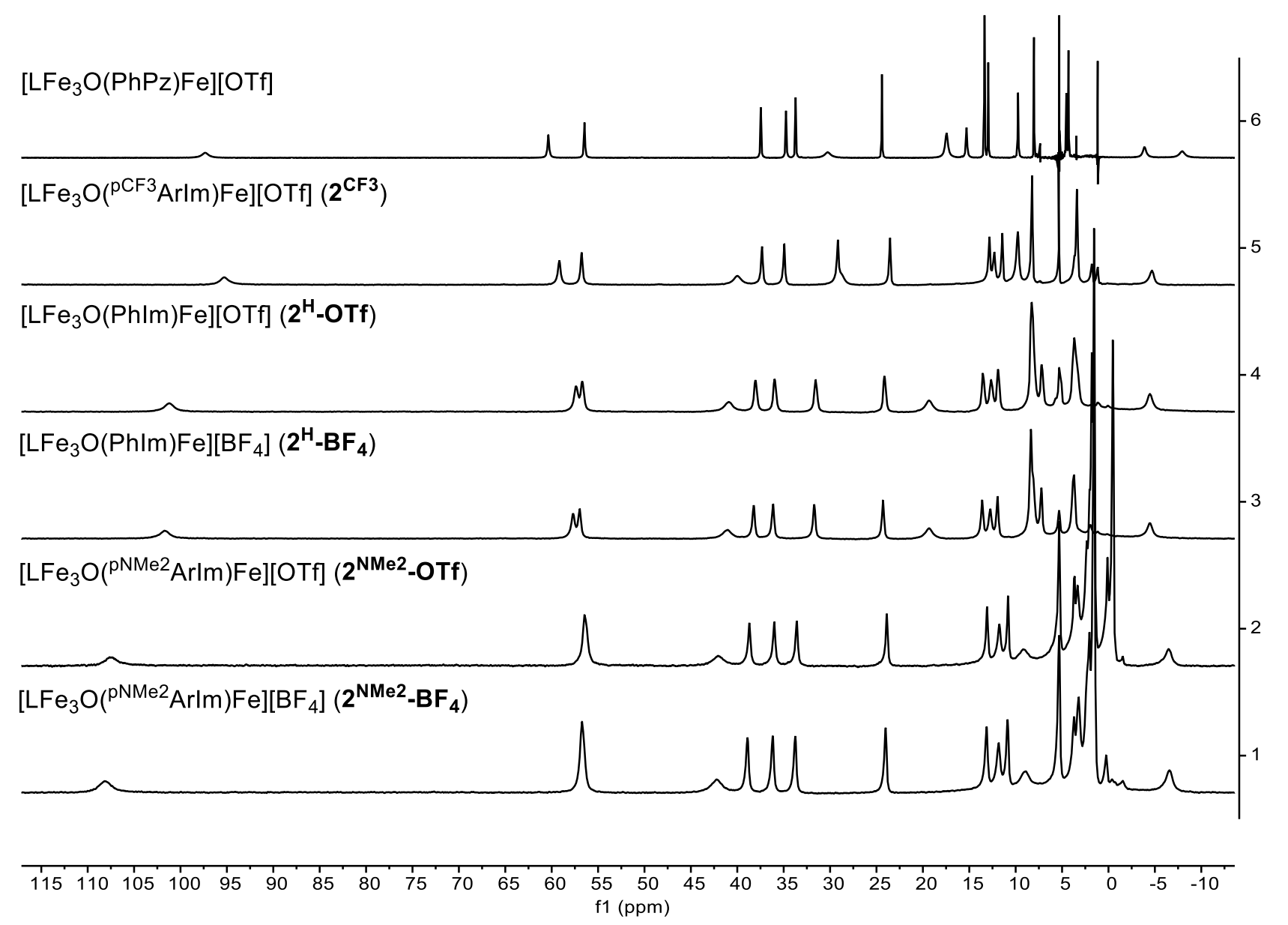

Figure S22. Comparison of ${ }^{1} \mathrm{H}$ NMR $(300 \mathrm{MHz})$ of $\left[\mathrm{LFe}_{3} \mathrm{O}(\mathrm{PhPz})_{3} \mathrm{Fe}\right][\mathrm{OTf}]$, $\left[\mathrm{LFe}_{3} \mathrm{O}\left({ }^{\mathrm{pCF}} \mathrm{ArIm}\right)_{3} \mathrm{Fe}\right][\mathrm{OTf}]\left(\mathbf{2}^{\mathbf{C F} 3}\right),\left[\mathrm{LFe}_{3} \mathrm{O}(\mathrm{PhIm})_{3} \mathrm{Fe}\right][\mathrm{OTf}]\left(\mathbf{2}^{\mathbf{H}}-\mathbf{O T f}\right),\left[\mathrm{LFe}_{3} \mathrm{O}(\mathrm{PhIm})_{3} \mathrm{Fe}\right]\left[\mathrm{BF}_{4}\right]$ $\left(\mathbf{2}^{\mathbf{H}}-\mathbf{B F}_{4}\right),\left[\mathrm{LFe}_{3} \mathrm{O}\left(\mathrm{pNMe}^{\mathrm{NM}} \mathrm{ArIm}\right)_{3} \mathrm{Fe}\right][\mathrm{OTf}]\left(\mathbf{2}^{\mathrm{NMe}} \mathbf{- O T f}\right)$, and $\left[\mathrm{LFe}_{3} \mathrm{O}\left(\mathrm{pNMe}^{\mathrm{NN}} \mathrm{ArIm}\right)_{3} \mathrm{Fe}\right]\left[\mathrm{BF}_{4}\right]\left(\mathbf{2}^{\mathrm{NMe}_{-}}\right.$ $\left.\mathbf{B F}_{4}\right)$ in $\mathrm{CD}_{2} \mathrm{Cl}_{2}$ 


\section{Variable Temperature IR Spectroscopy}

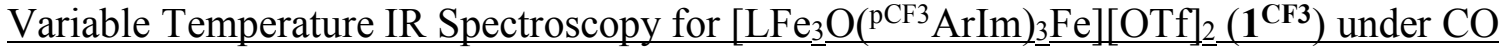

Dry dichloromethane $(11.5 \mathrm{~mL})$ was injected into a ReactIR cell under positive pressure of Ar. Background spectra were collected at $298 \mathrm{~K}, 273 \mathrm{~K}$ (ice bath) and $195 \mathrm{~K}$ (dry ice/acetone bath). Under counter flow of Ar, $2 \mathrm{~mL}$ of dichloromethane was syringed out of the ReactIR cell and replaced with a solution of $\left[\mathrm{LFe}_{3} \mathrm{O}\left({ }^{\mathrm{pCF}} \mathrm{ArIm}\right)_{3} \mathrm{Fe}\right][\mathrm{OTf}]_{2}\left(\mathbf{1}^{\mathrm{CF} 3}, 76.4 \mathrm{mg}\right)$ in dichloromethane (2 $\mathrm{mL})$. IR spectra of $\left[\mathrm{LFe}_{3} \mathrm{O}\left({ }^{\mathrm{pCF} 3} \mathrm{ArIm}\right)_{3} \mathrm{Fe}\right][\mathrm{OTf}]_{2}\left(\mathbf{1}^{\mathrm{CF} 3}\right)$ were collected at $298 \mathrm{~K}, 273 \mathrm{~K}$ (ice bath) and $195 \mathrm{~K}$ (dry ice/acetone) which revealed no vibrational features in the window of 1850-2200 $\mathrm{cm}^{-1}$. The ReactIR cell was removed from the probe under counter flow of $\mathrm{Ar}$ and sealed. The solution was degassed in the cell by three freeze-pump-thaw cycles and then exposed to $\mathrm{CO}$ at 195 $\mathrm{K}(\sim 1.5 \mathrm{~atm}$.). The ReactIR cell was stirred vigorously at $195 \mathrm{~K}$ for 15 minutes and then reattached to the probe under counter flow of Ar as quickly as possible. IR spectra collected with the cell maintained at $195 \mathrm{~K}$ under flow of Ar revealed a strong Fe-CO vibration at $1947 \mathrm{~cm}^{-1}$ assignable to $\left[\mathrm{LFe}_{3} \mathrm{O}\left({ }^{\mathrm{PCF} 3} \mathrm{ArIm}\right)_{3} \mathrm{Fe}(\mathrm{CO})\right][\mathrm{OTf}]_{2}\left(\mathbf{1}^{\mathrm{CF} 3}-\mathrm{CO}\right)$ and weaker features at $2015 \mathrm{~cm}^{-1}$ and $1961 \mathrm{~cm}^{-1}$ assignable to $\left[\mathrm{LFe}_{3} \mathrm{O}\left({ }^{\mathrm{PCF} 3} \mathrm{ArIm}\right)_{3} \mathrm{Fe}(\mathrm{CO})_{2}\right](\mathrm{OTf})_{2}\left(\mathbf{1}^{\mathbf{C F} 3}-(\mathbf{C O})_{2}\right){ }^{5}$ At $273 \mathrm{~K}$, only the signal from $\left[\mathrm{LFe}_{3} \mathrm{O}\left({ }^{\mathrm{pCF} 3} \mathrm{ArIm}\right)_{3} \mathrm{Fe}(\mathrm{CO})\right][\mathrm{OTf}]_{2}\left(\mathbf{1}^{\mathrm{CF}}-\mathrm{CO}\right)$ at $1947 \mathrm{~cm}^{-1}$ remained.

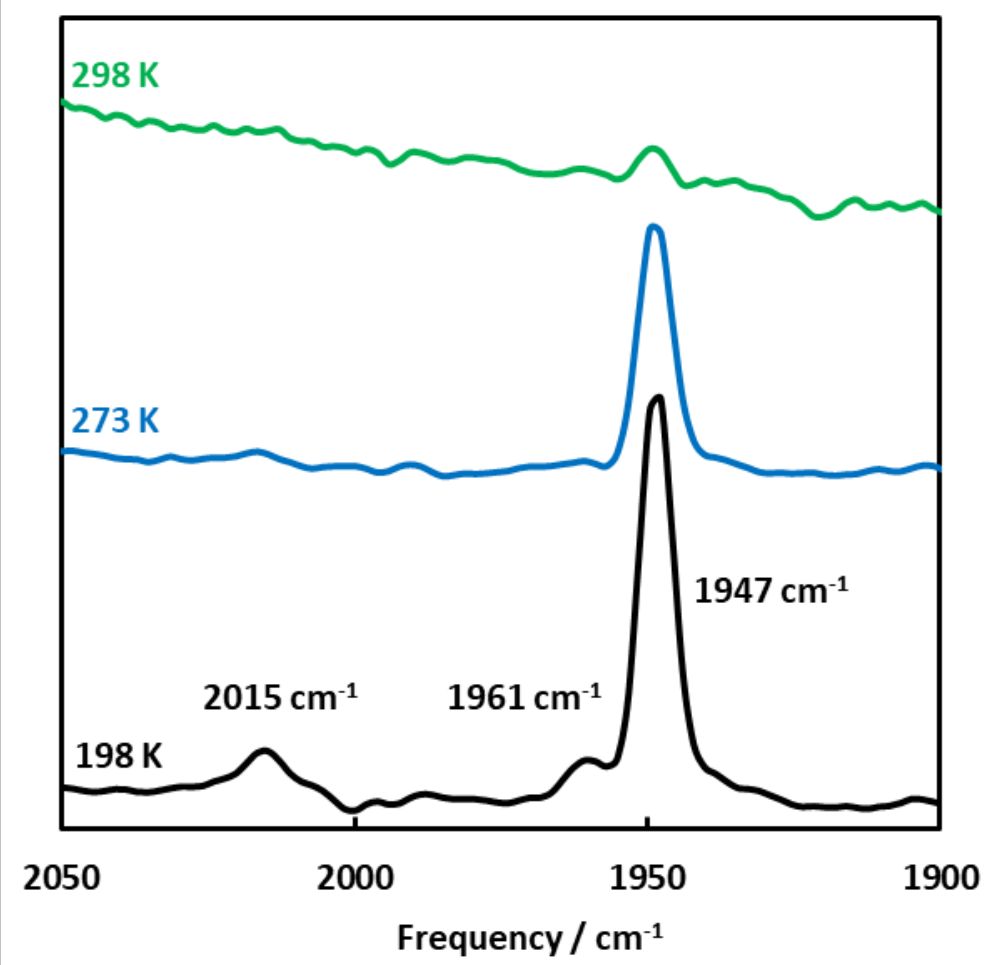

Figure S23. VT-IR (ReactIR) spectroscopy of $\left[\mathrm{LFe}_{3} \mathrm{O}\left({ }^{\text {(CF3 }} \mathrm{ArIm}\right)_{3} \mathrm{Fe}\right][\mathrm{OTf}]_{2}\left(\mathbf{1}^{\mathrm{CF} 3}\right.$, in $\left.\mathrm{CH}_{2} \mathrm{Cl}_{2}\right)$ starting at $195 \mathrm{~K}$ (black) in CO-saturated solution following an Ar purge. 
Variable Temperature IR Spectroscopy for $\left[\mathrm{LFe}_{\underline{3}} \mathrm{O}\left({ }^{\mathrm{pOMe}} \mathrm{ArIm}\right)_{\underline{3}} \underline{\mathrm{Fe}}\right][\mathrm{OTf}]_{\underline{2}}\left(\mathbf{1}^{\mathrm{OMe}}\right)$ under $\mathrm{CO}$

Dry dichloromethane $(11.5 \mathrm{~mL})$ was injected into a ReactIR cell under positive pressure of Ar. Background spectra were collected at $298 \mathrm{~K}, 273 \mathrm{~K}$ (ice bath) and $195 \mathrm{~K}$ (dry ice/acetone bath). Under counter flow of Ar, $2 \mathrm{~mL}$ of dichloromethane was syringed out of the ReactIR cell and replaced with a solution of $\left[\mathrm{LFe}_{3} \mathrm{O}\left({ }^{\mathrm{pOMe}} \mathrm{ArIm}\right)_{3} \mathrm{Fe}\right][\mathrm{OTf}]_{2}\left(1^{\mathrm{OMe}}, 65.0 \mathrm{mg}\right)$ in dichloromethane (2 $\mathrm{mL})$. IR spectra of $\left[\mathrm{LFe}_{3} \mathrm{O}\left({ }^{\mathrm{pOMe}} \mathrm{ArIm}\right){ }_{3} \mathrm{Fe}\right][\mathrm{OTf}]_{2}\left(\mathbf{1}^{\mathrm{OMe}}\right)$ were collected at $298 \mathrm{~K}, 273 \mathrm{~K}$ (ice bath) and $195 \mathrm{~K}$ (dry ice/acetone) which revealed no vibrational features in the window of 1850-2200 $\mathrm{cm}^{-1}$. The ReactIR cell was removed from the probe under counter flow of $\mathrm{Ar}$ and sealed. The solution was degassed in the cell by three freeze-pump-thaw cycles and then exposed to $\mathrm{CO}$ at 195 $\mathrm{K}(\sim 1.5 \mathrm{~atm}$.). The ReactIR cell was stirred vigorously at $195 \mathrm{~K}$ for 15 minutes and then reattached to the probe under counter flow of Ar as quickly as possible. IR spectra collected with the cell maintained at $195 \mathrm{~K}$ under flow of Ar revealed a strong Fe-CO vibration at $1942 \mathrm{~cm}^{-1}$ assignable to $\left[\mathrm{LFe}_{3} \mathrm{O}\left({ }^{\left(\mathrm{POMe}^{\circ}\right.} \mathrm{ArIm}\right)_{3} \mathrm{Fe}(\mathrm{CO})\right][\mathrm{OTf}]_{2}\left(\mathbf{1}^{\left.\mathrm{OMe}_{-} \mathrm{CO}\right)}\right.$ and weaker features at $2013 \mathrm{~cm}^{-1}$ and $1955 \mathrm{~cm}^{-1}$ assignable to $\left.\left[\mathrm{LFe}_{3} \mathrm{O}\left({ }^{\mathrm{pOMe}} \mathrm{ArIm}\right)_{3} \mathrm{Fe}(\mathrm{CO})_{2}\right](\mathrm{OTf})_{2}\left(\mathbf{1}^{\mathbf{O M e}_{-}}-\mathbf{C O}\right)_{2}\right)$.

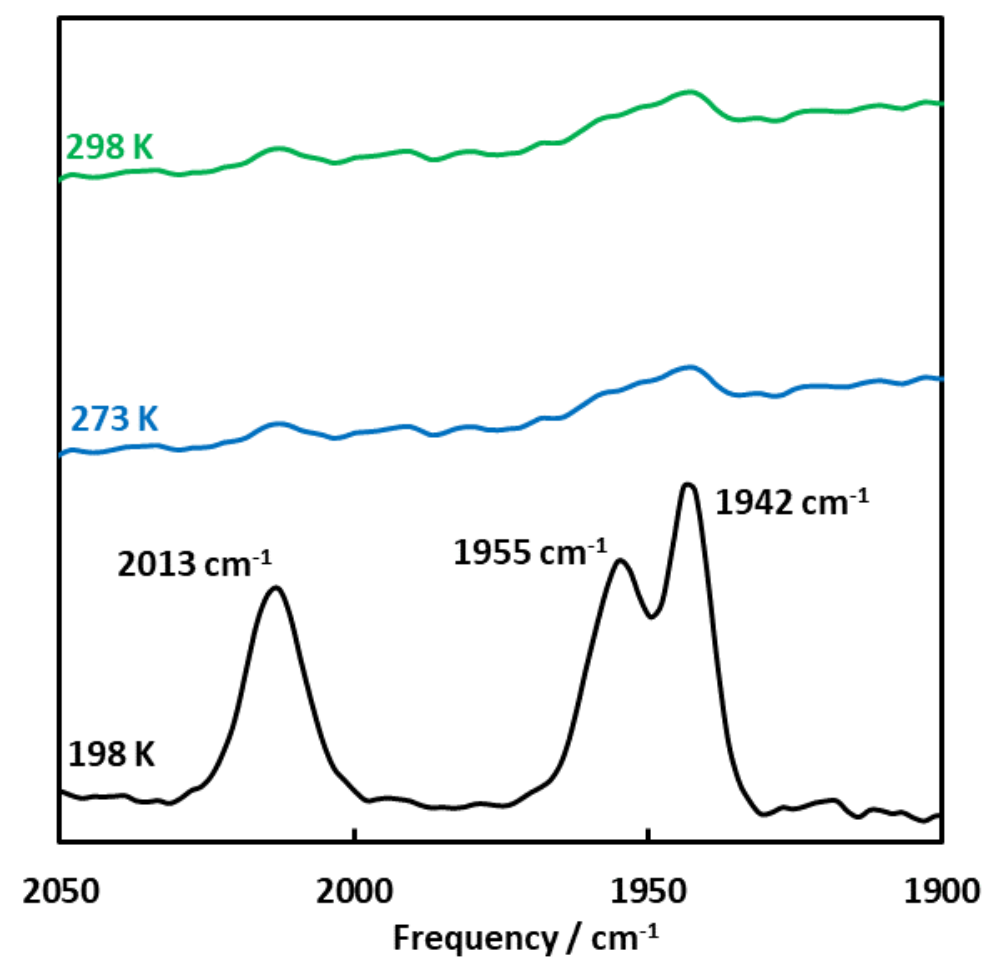

Figure S24. VT-IR (ReactIR) spectroscopy of [ $\left[\mathrm{LFe}_{3} \mathrm{O}\left({ }^{\mathrm{pOMe}} \mathrm{ArIm}\right){ }_{3} \mathrm{Fe}\right][\mathrm{OTf}]_{2}\left(\mathbf{1}^{\mathrm{OMe}}\right.$, in $\left.\mathrm{CH}_{2} \mathrm{Cl}_{2}\right)$ starting at $195 \mathrm{~K}$ (black) in CO-saturated solution following an Ar purge. 
Variable Temperature IR Spectroscopy for $\left[\mathrm{LFe}_{3} \underline{\mathrm{O}}\left({ }^{\mathrm{pNMe} 2} \mathrm{ArIm}\right) \underline{3} \underline{\mathrm{Fe}}\right][\mathrm{OTf}]_{2}\left(\mathbf{1}^{\mathrm{NMe} 2}\right)$ under $\mathrm{CO}$

Dry dichloromethane $(11.5 \mathrm{~mL})$ was injected into a ReactIR cell under positive pressure of Ar. Background spectra were collected at $298 \mathrm{~K}, 273 \mathrm{~K}$ (ice bath) and $195 \mathrm{~K}$ (dry ice/acetone bath). Under counter flow of $\mathrm{Ar}, 2 \mathrm{~mL}$ of dichloromethane was syringed out of the ReactIR cell and replaced with a solution of $\left[\mathrm{LFe}_{3} \mathrm{O}\left({ }^{\mathrm{pNMe} 2} \mathrm{ArIm}\right)_{3} \mathrm{Fe}\right][\mathrm{OTf}]_{2}\left(\mathbf{1}^{\mathrm{NMe} 2}, 66.3 \mathrm{mg}\right)$ in dichloromethane $(2$ $\mathrm{mL})$. IR spectra of $\left[\mathrm{LFe}_{3} \mathrm{O}\left({ }^{\mathrm{pNMe} 2} \mathrm{ArIm}\right)_{3} \mathrm{Fe}\right][\mathrm{OTf}]_{2}\left(\mathbf{1}^{\mathrm{NMe} 2}\right)$ were collected at $298 \mathrm{~K}, 273 \mathrm{~K}$ (ice bath) and $195 \mathrm{~K}$ (dry ice/acetone) which revealed no vibrational features in the window of 1850-2200 $\mathrm{cm}^{-1}$. The ReactIR cell was removed from the probe under counter flow of Ar and sealed. The solution was degassed in the cell by three freeze-pump-thaw cycles and then exposed to CO at 195 $\mathrm{K}(\sim 1.5 \mathrm{~atm}$.). The ReactIR cell was stirred vigorously at $195 \mathrm{~K}$ for 15 minutes and then reattached to the probe under counter flow of Ar as quickly as possible. IR spectra collected with the cell maintained at $195 \mathrm{~K}$ under flow of Ar revealed strong Fe-CO vibration features at $2013 \mathrm{~cm}^{-1}$ and $1957 \mathrm{~cm}^{-1}$ assignable to $\left.\left[\mathrm{LFe}_{3} \mathrm{O}\left({ }^{\mathrm{pNMe} 2} \mathrm{ArIm}\right)_{3} \mathrm{Fe}(\mathrm{CO})_{2}\right](\mathrm{OTf})_{2}\left(\mathbf{1}^{\mathrm{NMe}}-\mathbf{C O}\right)_{2}\right)$. After warming to 273 $\mathrm{K}$, no Fe-CO vibrational features were discernable.

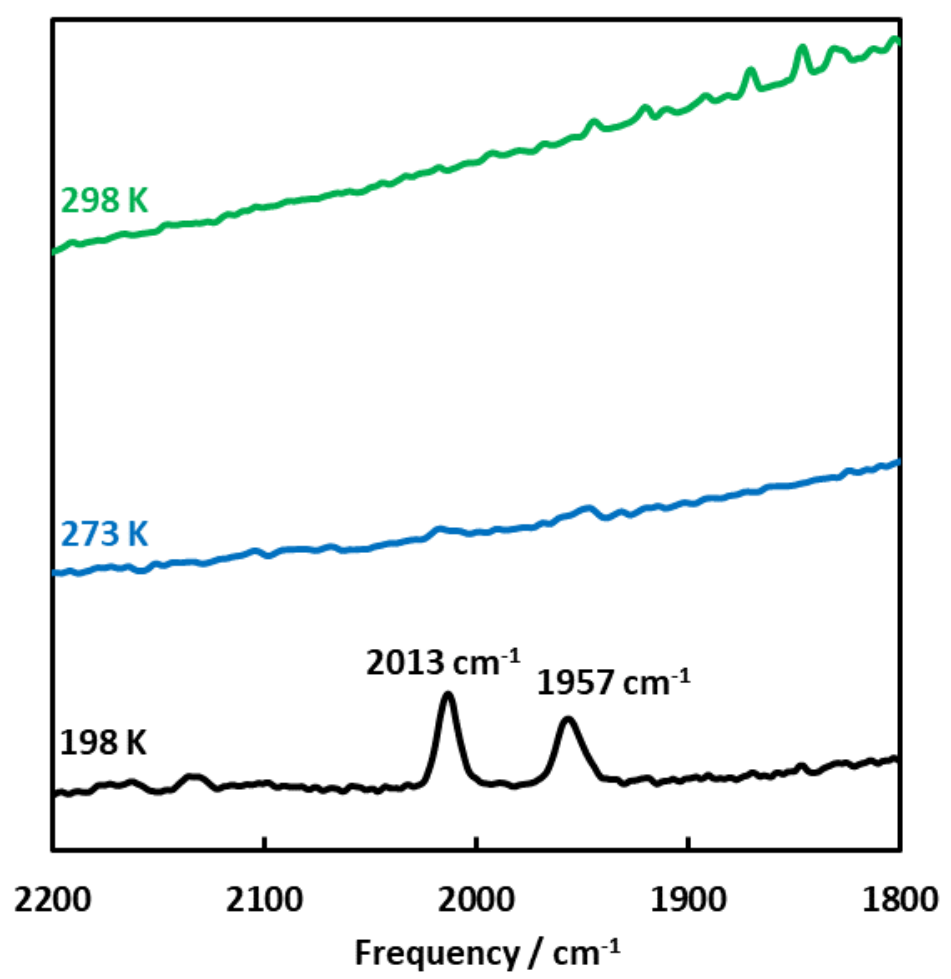

Figure S25. VT-IR (ReactIR) spectroscopy of $\left[\mathrm{LFe}_{3} \mathrm{O}\left({ }^{\mathrm{pNMe} 2} \mathrm{ArIm}\right)_{3} \mathrm{Fe}\right][\mathrm{OTf}]_{2}\left(\mathbf{1}^{\mathrm{NMe} 2}\right.$, in $\left.\mathrm{CH}_{2} \mathrm{Cl}_{2}\right)$ starting at $195 \mathrm{~K}$ (black) in CO-saturated solution following an Ar purge. 
Substituent Effect on $v(\mathrm{CO})$ :

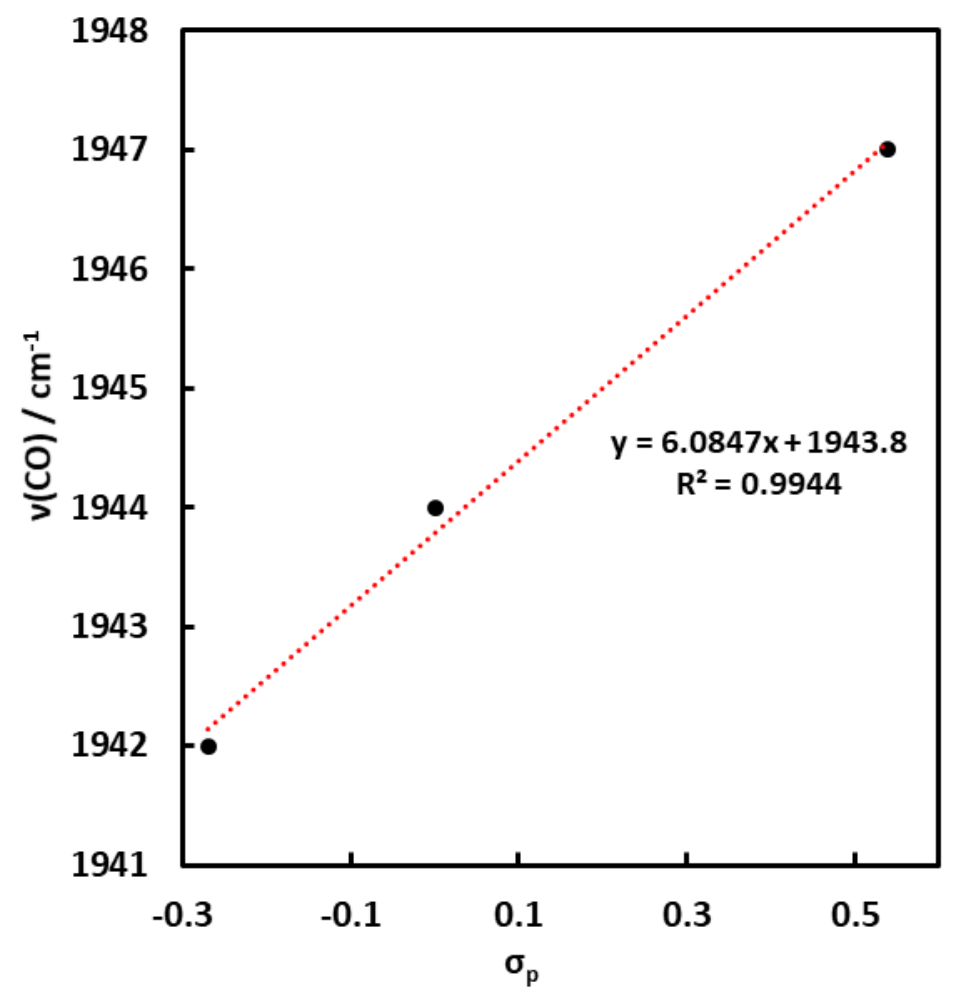

Figure S26. Correlation of $v(\mathrm{CO})$ values for $\left[\mathrm{LFe}_{3} \mathrm{O}\left({ }^{\mathrm{R}} \mathrm{ArIm}\right)_{3} \mathrm{Fe}(\mathrm{CO})\right][\mathrm{OTf}]_{2}$ with their Hammett substituent constants. 


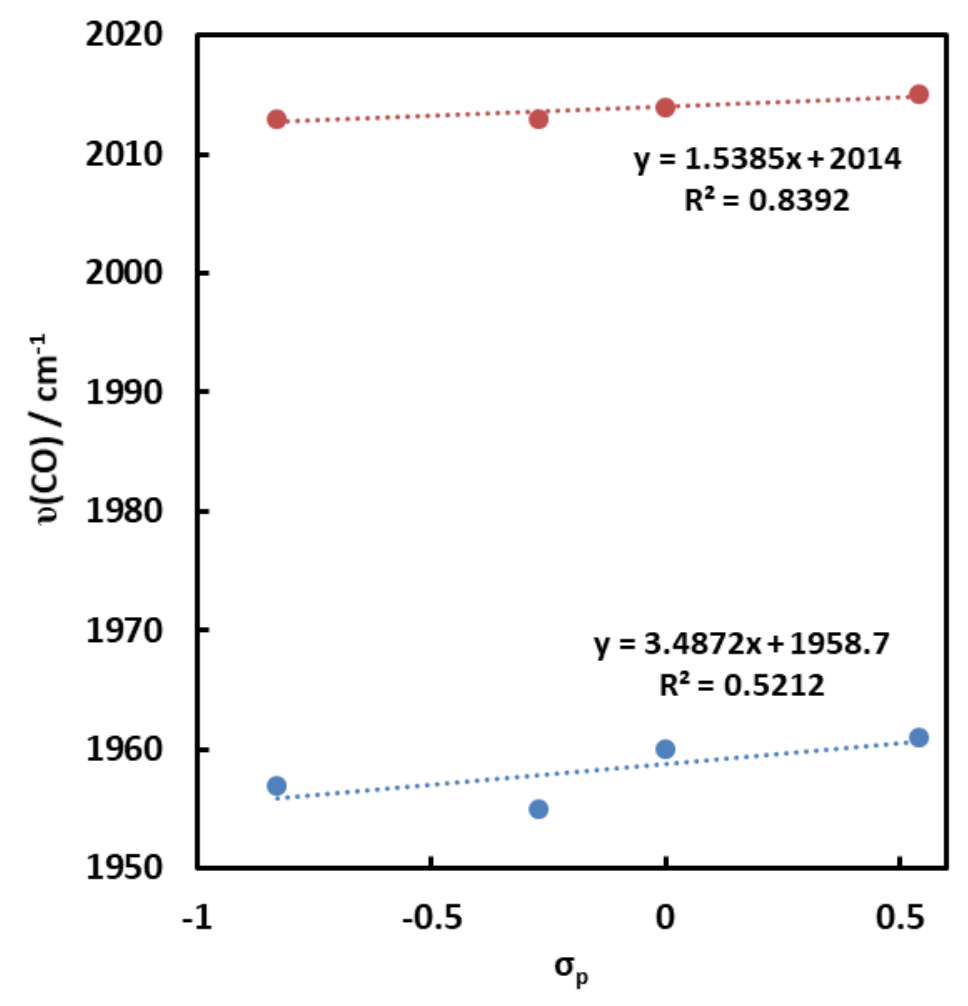

Figure S27. Correlation of $v(\mathrm{CO})$ values for $\left[\mathrm{LFe}_{3} \mathrm{O}\left({ }^{\mathrm{R}} \mathrm{ArIm}\right)_{3} \mathrm{Fe}(\mathrm{CO})_{2}\right][\mathrm{OTf}]_{2}$ with their Hammett substituent constants.

Table S1. Comparison of $v(\mathrm{CO})$ values for $\left[\mathrm{LFe}_{3} \mathrm{O}\left({ }^{\mathrm{R}} \mathrm{ArIm}\right)_{3} \mathrm{Fe}(\mathrm{CO})\right][\mathrm{OTf}]_{2}$ and $\left[\mathrm{LFe}_{3} \mathrm{O}\left({ }^{\mathrm{R}} \mathrm{ArIm}\right)_{3} \mathrm{Fe}\right][\mathrm{OTf}]_{2}$.

\begin{tabular}{c|c|c|c|c}
$\mathrm{v}(\mathrm{CO}) / \mathrm{cm}^{-1}$ & $\mathrm{R}=\mathrm{NMe}_{2}$ & $\mathrm{R}=\mathrm{OMe}$ & $\mathrm{R}=\mathrm{H}$ & $\mathrm{R}=\mathrm{CF}_{3}$ \\
\hline $\begin{array}{c}\text { Monocarbonyl } \\
\text { Dicarbonyl }\end{array}$ & --- & 1942 & 1944 & 1947 \\
$1957 / 2013$ & $1955 / 2013$ & $1960 / 2014$ & $1961 / 2015$
\end{tabular}




\section{Variable Temperature NMR Spectroscopy and Thermodynamic Measurements}

General Considerations: For the NMR experiments reported herein, conditions were selected such that at full conversion the pressure of $\mathrm{CO}$ gas in the headspace would remain near $1 \mathrm{~atm}$. The $\mathrm{J}$ Young NMR tubes employed had a sealed volume of $\sim 3 \mathrm{~mL}$. All experiments were conducted such that the volume of the analyte solution + internal reference solution accounted for $\sim 0.45 \mathrm{~mL}$, leaving a headspace volume of $2.65 \mathrm{~mL}$. The tubes were degassed by three freeze-pump-thaw cycles, with mixing between each cycle. Gas addition was made after equilibrating in a water bath held at $293 \mathrm{~K}$. Using PV $=\mathrm{nRT}$, the amount of $\mathrm{CO}$ in the headspace is $\sim 0.11 \mathrm{mmol}$, with $\sim 0.006$ mmol dissolved in solution at $293 \mathrm{~K}$. For $\sim 0.004 \mathrm{mmol}$ cluster delivered to the tube, full conversion consumes $0.008 \mathrm{mmol}$ of $\mathrm{CO}$ or $\sim 7 \%$ of the $\mathrm{CO}$ in the tube. After thorough mixing, spectra were then recorded at the listed temperatures with the sample equilibrated with spinning in the spectrometer for at least 10 minutes. As longer equilibration times did not influence the integrations, we assume herein that our method allows for sufficient diffusion of $\mathrm{CO}$ from the headspace to saturate the solution. We note that for most organic solvents, it appears the solubility of $\mathrm{CO}$ does not vary by more than $10-15 \%$ even over temperature ranges as large as $100 \mathrm{~K}$. All changes were fully reversible.

Thermodynamics of $\mathrm{CO}$ Binding to $\left[\mathrm{LFe}_{3} \mathrm{O}\left({ }^{\mathrm{PCF} 3} \mathrm{ArIm}\right)_{3} \mathrm{Fe}\right][\mathrm{OTf}]_{2}\left(1^{\mathrm{CF} 3}\right)$ in dichloromethane- $d_{2}$ A stock solution of $\left[\mathrm{LFe}_{3} \mathrm{O}\left({ }^{\mathrm{pCF} 3} \mathrm{ArIm}\right)_{3} \mathrm{Fe}\right][\mathrm{OTf}]_{2}\left(1^{\mathrm{CF} 3}\right)$ was prepared by dissolving $10.4 \mathrm{mg}$ of $\left[\mathrm{LFe}_{3} \mathrm{O}\left({ }^{\mathrm{PCF}} \mathrm{ArIm}\right)_{3} \mathrm{Fe}\right][\mathrm{OTf}]_{2}\left(\mathbf{1}^{\mathrm{CF} 3}\right)$ in $0.60 \mathrm{~mL}$ dry $\mathrm{CD}_{2} \mathrm{Cl}_{2}$. A stock solution of $\left[\mathrm{Fc}^{*}\right][\mathrm{OTf}]$ was prepared by dissolving $8.8 \mathrm{mg}$ in $0.92 \mathrm{~mL} \mathrm{CD}_{2} \mathrm{Cl}_{2}$. A $0.05 \mathrm{~mL}$ aliquot of the [ $\left.\mathrm{Fc}^{*}\right]$ [OTf] stock solution was transferred to a capillary and flame sealed. An aliquot $(0.35 \mathrm{~mL})$ of the $\left[\mathrm{LFe}_{3} \mathrm{O}\left({ }^{(\mathrm{PCF} 3} \mathrm{ArIm}\right)_{3} \mathrm{Fe}\right][\mathrm{OTf}]_{2}\left(\mathbf{1}^{\mathrm{CF} 3}\right)$ stock solution and the sealed $\left[\mathrm{Fc}^{*}\right][\mathrm{OTf}]$ capillary were transferred to a J. Young tube. After recording the ${ }^{1} \mathrm{H}-\mathrm{NMR}$ spectrum in the absence of $\mathrm{CO}$, the solution was degassed by three freeze-pump-thaw cycles and then CO $(1 \mathrm{~atm}$.) was admitted at $293 \mathrm{~K}$ and spectra were then recorded between $203-308 \mathrm{~K}$. Separately, the VT- ${ }^{1} \mathrm{H}$ NMR spectrum of $\left[\mathrm{LFe}_{3} \mathrm{O}\left({ }^{\mathrm{PCF}} \mathrm{ArIm}\right)_{3} \mathrm{Fe}\right][\mathrm{OTf}]_{2}\left(\mathbf{1}^{\mathrm{CF} 3}\right)$ was measured under $\mathrm{N}_{2}$.

For the formation of $\mathbf{1}^{\mathrm{CF}}-\mathbf{C O}$ :

$$
\begin{gathered}
K_{\mathrm{p}, 1}=\left[\mathbf{1}^{\mathrm{CF} 3}-\mathrm{CO}\right] /\left[\mathbf{1}^{\mathrm{CF} 3}\right]^{*} \mathrm{P}_{\mathrm{CO}} \\
{\left[\mathbf{1}^{\mathrm{CF} 3}-\mathrm{CO}\right]=\left[\mathbf{1}^{\mathrm{CF}}\right]_{\text {initial }}-\left[\mathbf{1}^{\mathrm{CF} 3}\right]_{\text {equilibrium }}-\left[\mathbf{1}^{\mathrm{CF} 3}-(\mathrm{CO})_{2}\right]_{\text {equilibrium }}}
\end{gathered}
$$

The value of $\left[\mathbf{1}^{\mathbf{C F} 3}\right]_{\text {equilibrium }}$ is determined according to:

$$
\left[\mathbf{1}^{\mathrm{CF} 3}\right]_{\text {equilibrium }}=\left(\mathrm{I}_{\mathrm{with}} \mathrm{CO} / \mathrm{I}_{\mathrm{noCO}}\right) *\left[\mathbf{1}^{\mathrm{CF} 3}\right]_{\text {initial }}
$$

Where $\mathrm{I}_{\text {withCo }}$ and $\mathrm{I}_{\text {noco }}$ are the integrals of ${ }^{1} \mathrm{H}-\mathrm{NMR}$ feature for $\mathbf{1}^{\mathbf{C F} 3}$ which starts at $26.35 \mathrm{ppm}$ at $298 \mathrm{~K}$ in the presence or absence of $\mathrm{CO}$, respectively, all relative to [ $\left.\mathrm{Fc}^{*}\right][\mathrm{OTf}]$ internal standard.

The value of $\left[\mathbf{1}^{\mathrm{CF} 3}-(\mathbf{C O})_{2}\right]_{\text {equilibrium }}$ is determined according to:

$$
\left[1^{\mathrm{CF} 3}-(\mathrm{CO})_{2}\right]_{\text {equilibrium }}=\left(\mathrm{I}_{\mathrm{T}} / \mathrm{I}_{203 \mathrm{~K}}\right) *\left[\mathbf{1}^{\mathrm{CF} 3}\right]_{\text {initial }}
$$

Where $\mathrm{I}_{203 \mathrm{~K}}$ is the integral of the ${ }^{1} \mathrm{H}-\mathrm{NMR}$ feature for $\mathbf{1}^{\mathbf{C F} 3}-(\mathbf{C O})_{2}$, relative to $\left[\mathrm{Fc}^{*}\right][\mathrm{OTf}]$ internal standard, which starts at $84.59 \mathrm{ppm}$ at $288 \mathrm{~K}$ and it is assumed that $100 \%$ of $\mathbf{1}^{\mathrm{CF} 3}$ has converted to 
$\left.\mathbf{1}^{\mathbf{C F} 3}-\mathbf{C O O}\right)_{2}$ by $203 \mathrm{~K}$. $\mathrm{I}_{\mathrm{T}}$ is the integral relative to $\left[\mathrm{Fc}^{*}\right][\mathrm{OTf}]$ of this feature at the given temperature.

Van’t Hoff analysis:

$$
\ln \left(K_{\mathrm{p}, 1}\right)=-\Delta H / \mathrm{RT}+\Delta S / \mathrm{R}
$$

Best Fit Line: $\ln \left(K_{\mathrm{p}, 1}\right)=-31.2(+/-0.8)+9311(+/-216) * 1 / \mathrm{T}$

Yields:

$$
\begin{gathered}
\Delta H=-18.5(4) \mathrm{kcal} \mathrm{mol}^{-1} \\
\Delta S=-62(2) \mathrm{cal} \mathrm{mol}^{-1} \mathrm{~K}^{-1} \\
K_{\mathrm{p}, 1}(278 \mathrm{~K})=9.3 \mathrm{~atm}^{-1}
\end{gathered}
$$

For the formation of $\mathbf{1}^{\mathbf{C F}}-(\mathbf{C O})_{2}$ :

$$
\begin{gathered}
K_{\mathrm{p}, 2}=\left[\mathbf{1}^{\mathbf{C F} 3}-(\mathbf{C O})_{2}\right] /\left[\mathbf{1}^{\mathbf{C F} 3}-\mathbf{C O}\right]^{*} \mathrm{P}_{\mathrm{CO}} \\
\text { Where }\left[\mathbf{1}^{\mathbf{C F 3}}-\mathbf{C O}\right]=\left[\mathbf{1}^{\mathbf{C F 3}}-(\mathbf{C O})_{2}\right]_{\text {initial }}-\left[\mathbf{1}^{\mathbf{C F} 3}-(\mathbf{C O})_{2}\right]_{\text {equilibrium }}-\left[\mathbf{1}^{\mathbf{C F} 3}\right]_{\text {equilibrium }}
\end{gathered}
$$

Van't Hoff analysis:

$$
\ln \left(K_{\mathrm{p}, 2}\right)=-\Delta H / \mathrm{RT}+\Delta S / \mathrm{R}
$$

Best Fit Line: $\ln \left(K_{\mathrm{p}, 2}\right)=-15.6(+/-0.3)+3740(+/-74) * 1 / \mathrm{T}$

Yields: $\quad \Delta H=-7.4(1) \mathrm{kcal} \mathrm{mol}^{-1}$

$$
\begin{gathered}
\Delta S=-31.3(6) \mathrm{cal} \mathrm{mol}^{-1} \mathrm{~K}^{-1} \\
K_{\mathrm{p}, 2}(278 \mathrm{~K})=0.10 \mathrm{~atm}^{-1}
\end{gathered}
$$

298 K

278 K
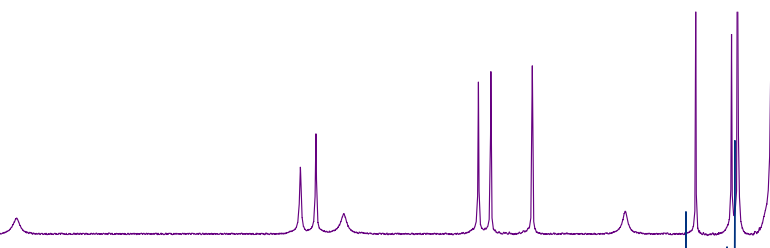

$258 \mathrm{~K}$

$238 \mathrm{~K}$
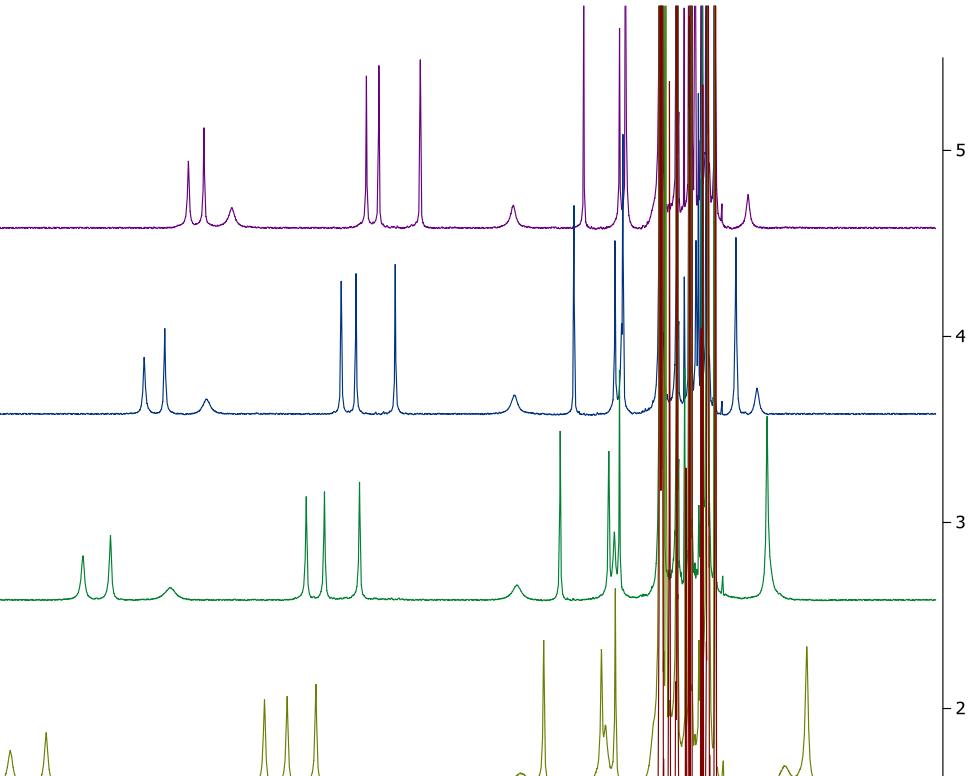

$218 \mathrm{~K}$

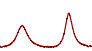

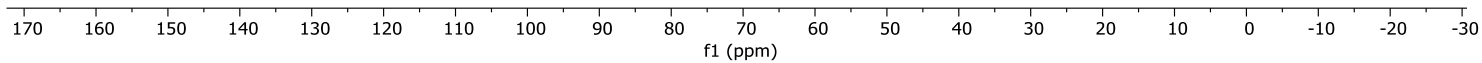

Figure S28. VT- ${ }^{1} \mathrm{H}$ NMR $(400 \mathrm{MHz})$ of $\left[\mathrm{LFe}_{3} \mathrm{O}\left({ }^{\mathrm{pCF} 3} \mathrm{ArIm}\right)_{3} \mathrm{Fe}\right][\mathrm{OTf}]_{2}\left(\mathbf{1}^{\mathrm{CF} 3}\right)$ in $\mathrm{CD}_{2} \mathrm{Cl}_{2}$ under $\mathrm{N}_{2}$ between $298 \mathrm{~K}$ (top) and $218 \mathrm{~K}$ (bottom) in $20 \mathrm{~K}$ intervals. 


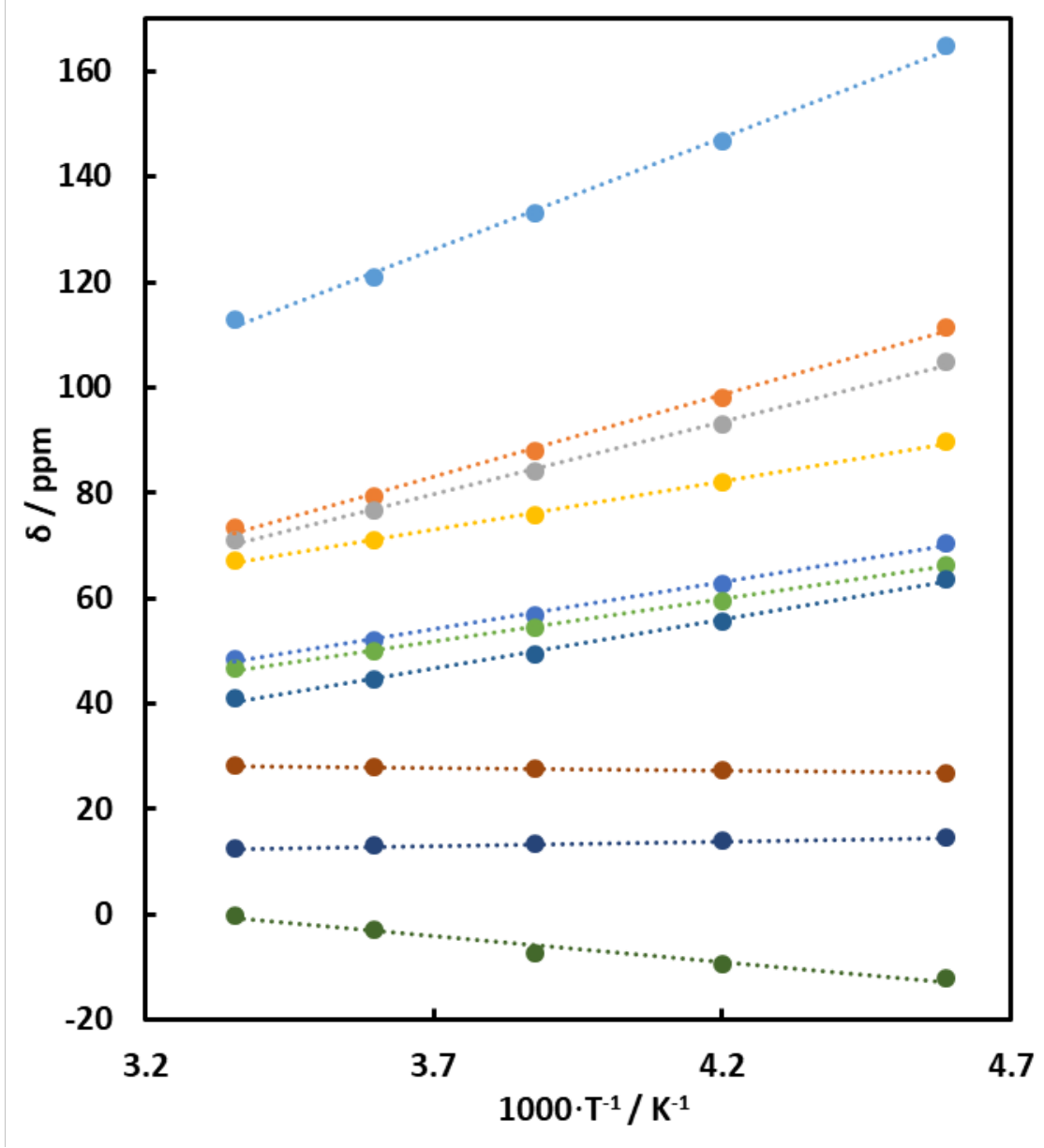

Figure S29. Curie plot showing the linear dependence (vs. the inverse temperature) of the ${ }^{1} \mathrm{H}$ chemical shift of selected protons (well resolved resonances) in $\left[\mathrm{LFe}_{3} \mathrm{O}\left({ }^{\mathrm{pCF} 3} \mathrm{ArIm}\right)_{3} \mathrm{Fe}\right][\mathrm{OTf}]_{2}$ $\left(\mathbf{1}^{\mathbf{C F 3}}\right)$ between 218 and $298 \mathrm{~K}$. The dashed lines are a guide to the eye. 

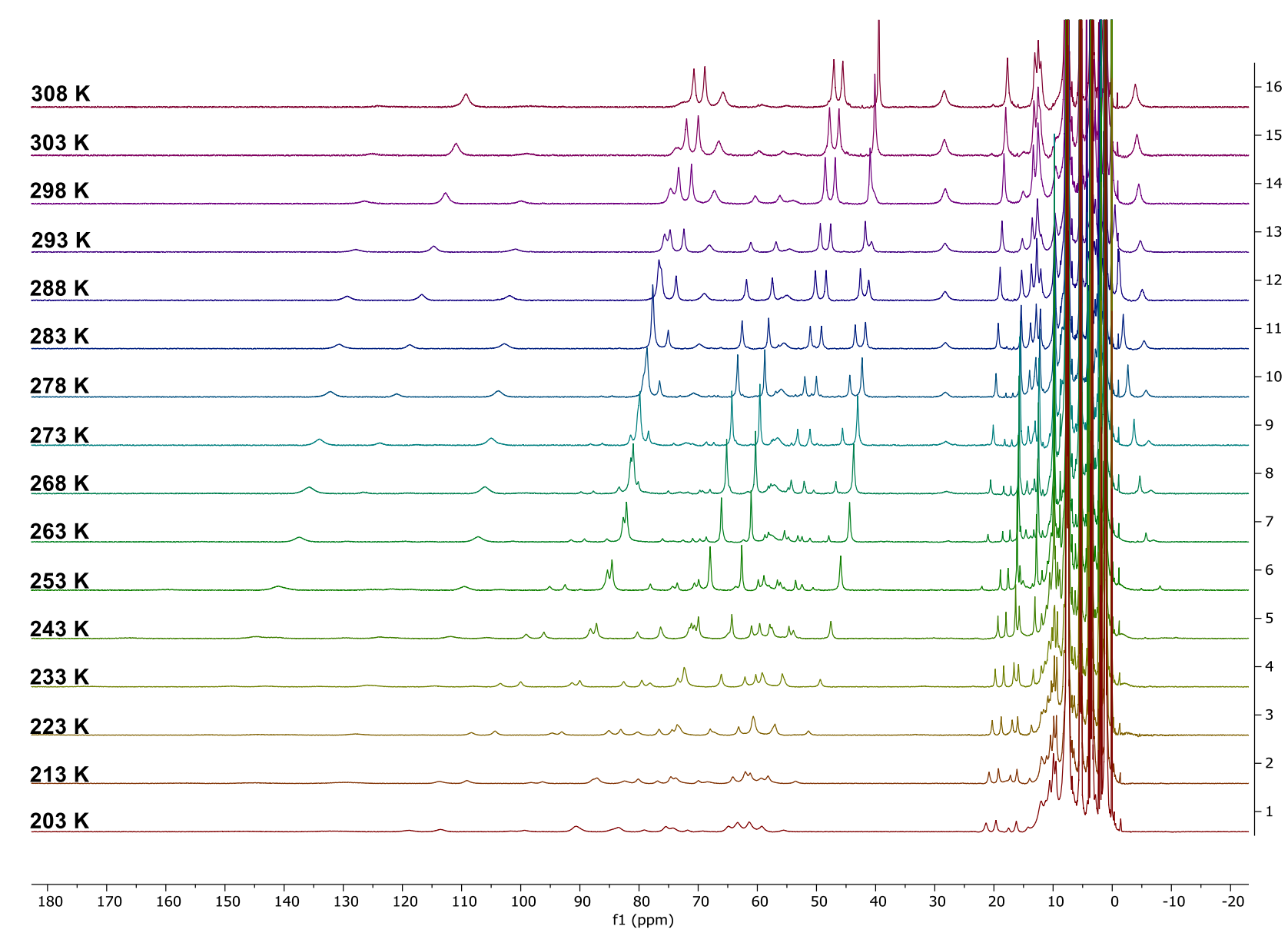

Figure S30. VT- ${ }^{1} \mathrm{H}$ NMR $(400 \mathrm{MHz})$ of $\left[\mathrm{LFe}_{3} \mathrm{O}\left({ }^{\mathrm{pCF}}{ }^{\mathrm{ArIm}}\right)_{3} \mathrm{Fe}\right][\mathrm{OTf}]_{2}\left(\mathbf{1}^{\mathrm{CF} 3}\right)$ in $\mathrm{CD}_{2} \mathrm{Cl}_{2}$ under CO (1 atm.) between $308 \mathrm{~K}$ (top) and $203 \mathrm{~K}$ (bottom). 


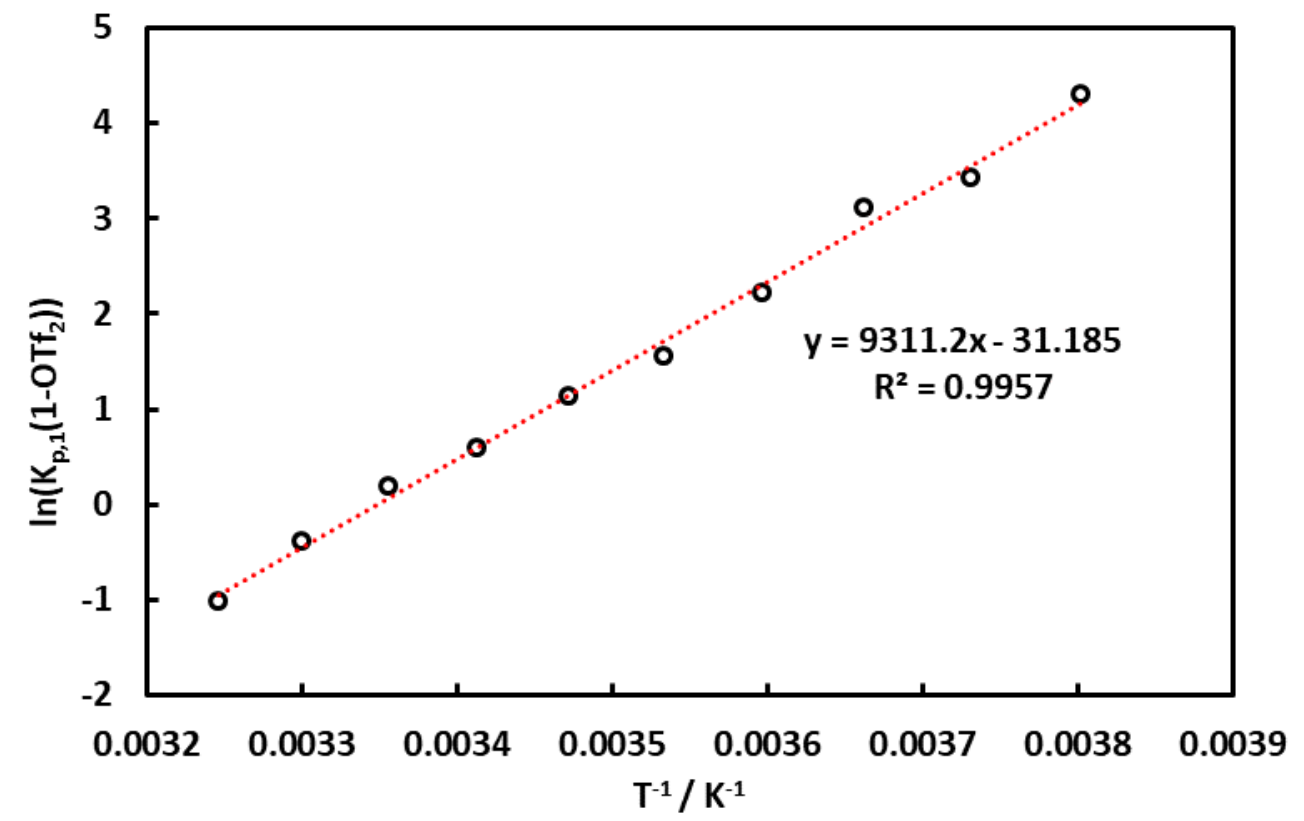

Figure S31. Van't Hoff plot for the formation of $\mathbf{1}^{\mathrm{CF}_{3}} \mathbf{C O}$ in dichloromethane- $d_{2}$ between 263$308 \mathrm{~K}$.

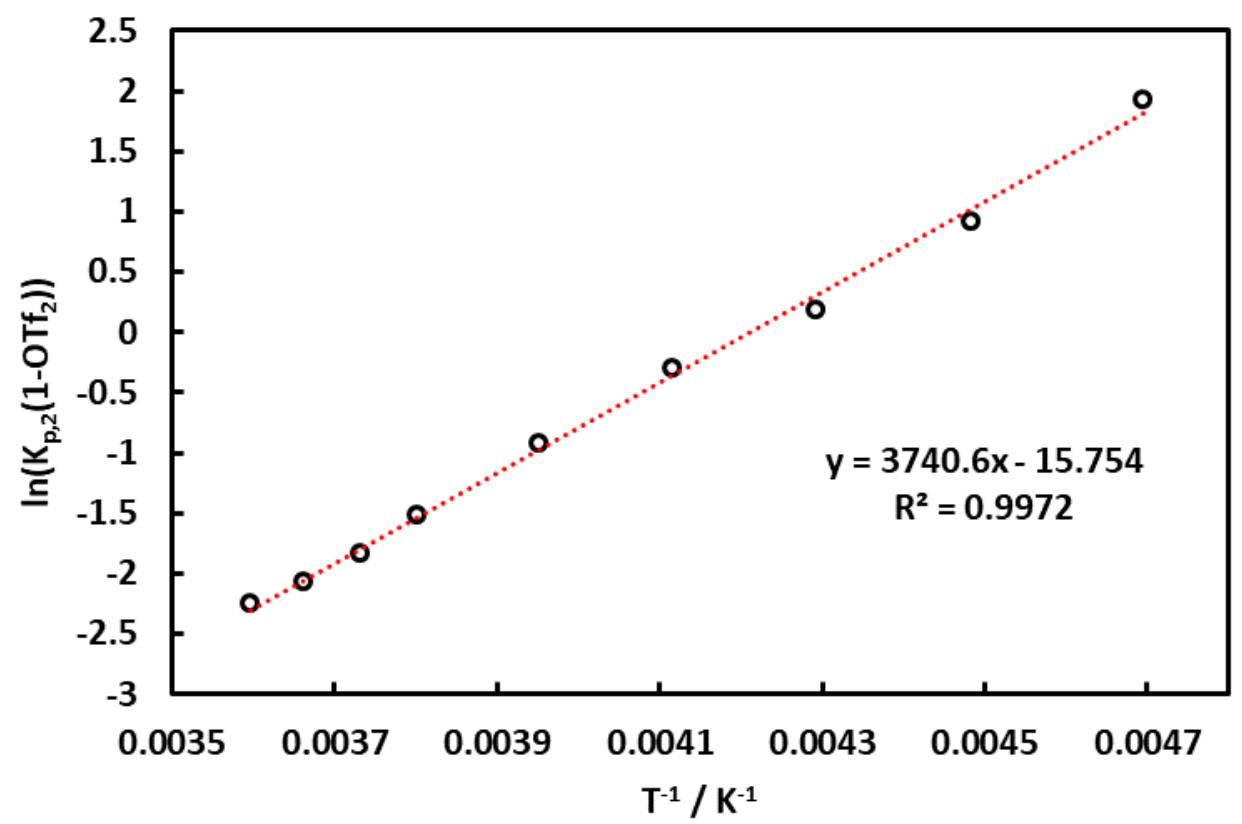

Figure S32. Van't Hoff plot for the formation of $\mathbf{1}^{\mathrm{CF}_{3}}-(\mathbf{C O})_{2}$ in dichloromethane- $d_{2}$ between $213-278 \mathrm{~K}$. 
Thermodynamics of $\mathrm{CO}$ Binding to $\left[\mathrm{LFe}_{3} \mathrm{O}\left({ }^{\mathrm{pOMe}} \mathrm{ArIm}\right)_{3} \mathrm{Fe}\right][\mathrm{OTf}]_{2}\left(1^{\mathrm{OMe}}\right)$ in dichloromethane- $d_{2}$ A stock solution of $\left[\mathrm{LFe}_{3} \mathrm{O}\left({ }^{\mathrm{pOMe}} \mathrm{ArIm}\right)_{3} \mathrm{Fe}\right][\mathrm{OTf}]_{2}\left(\mathbf{1}^{\mathrm{OMe}}\right)$ was prepared by dissolving $8.4 \mathrm{mg}$ of $\left[\mathrm{LFe}_{3} \mathrm{O}\left({ }^{\mathrm{POMe}} \mathrm{ArIm}\right)_{3} \mathrm{Fe}\right][\mathrm{OTf}]_{2}\left(\mathbf{1}^{\mathrm{OMe}}\right)$ in $0.50 \mathrm{~mL}$ dry $\mathrm{CD}_{2} \mathrm{Cl}_{2}$. A stock solution of $\left[\mathrm{Fc}^{*}\right][\mathrm{OTf}]$ was prepared by dissolving $11.7 \mathrm{mg}$ in $1.20 \mathrm{~mL} \mathrm{CD}_{2} \mathrm{Cl}_{2}$. A $0.05 \mathrm{~mL}$ aliquot of the [ $\left.\mathrm{Fc}^{*}\right]$ [OTf] stock solution was transferred to a capillary and flame sealed. An aliquot $(0.35 \mathrm{~mL})$ of the

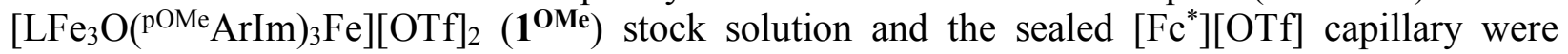
transferred to a J. Young tube. After recording the ${ }^{1} \mathrm{H}-\mathrm{NMR}$ spectrum in the absence of $\mathrm{CO}$, the solution was degassed by three freeze-pump-thaw cycles and then CO (1 atm.) was admitted at $293 \mathrm{~K}$ and spectra were then recorded between $213-298 \mathrm{~K}$. Separately, the VT- ${ }^{1} \mathrm{H}$ NMR spectrum of $\left[\mathrm{LFe}_{3} \mathrm{O}\left({ }^{\left(\mathrm{pOMe}^{2}\right.} \mathrm{ArIm}\right)_{3} \mathrm{Fe}\right][\mathrm{OTf}]_{2}\left(\mathbf{1}^{\mathrm{OMe}}\right)$ was measured under $\mathrm{N}_{2}$.

For the formation of $\mathbf{1}^{\mathrm{OMe}}-\mathbf{C O}$ :

$$
\begin{gathered}
K_{\mathrm{p}, 1}=\left[\mathbf{1}^{\mathrm{OMe}}-\mathrm{CO}\right] /\left[\mathbf{1}^{\mathrm{OMe}}\right]^{* \mathrm{P}_{\mathrm{CO}}} \\
{\left[\mathbf{1}^{\mathrm{OMe}}-\mathrm{CO}\right]=\left[\mathbf{1}^{\mathrm{OMe}}\right]_{\text {initial }}-\left[\mathbf{1}^{\mathrm{OMe}}\right]_{\text {equilibrium }}-\left[\mathbf{1}^{\text {OMe }}-(\mathrm{CO})_{2}\right]_{\text {equilibrium }}}
\end{gathered}
$$

The value of $\left[\mathbf{1}^{\text {OMe }}\right]_{\text {equilibrium }}$ is determined according to:

$$
\left[1^{\text {OMe }}\right]_{\text {equilibrium }}=\left(\mathrm{I}_{\text {withCO }} / \mathrm{I}_{\mathrm{noCO}}\right)^{*}\left[1^{\mathrm{OMe}}\right]_{\text {initial }}
$$

Where $\mathrm{I}_{\text {withCo }}$ and $\mathrm{I}_{\text {noCO }}$ are the integrals of ${ }^{1} \mathrm{H}-\mathrm{NMR}$ feature for $\mathbf{1}^{\mathrm{OMe}}$ which starts at $-6.76 \mathrm{ppm}$ at $288 \mathrm{~K}$ in the presence or absence of $\mathrm{CO}$, respectively, all relative to [ $\left.\mathrm{Fc}^{*}\right][\mathrm{OTf}]$ internal standard.

The value of $\left[\mathbf{1}^{\mathrm{OMe}}-(\mathbf{C O})_{2}\right]_{\text {equilibrium }}$ is determined according to:

$$
\left[1^{\mathrm{OMe}}-(\mathrm{CO})_{2}\right]_{\text {equilibrium }}=\left(\mathrm{I}_{\mathrm{T}} / \mathrm{I}_{223 \mathrm{~K}}\right) *\left[\mathbf{1}^{\mathrm{OMe}}\right]_{\text {initial }}
$$

Where $\mathrm{I}_{223 \mathrm{~K}}$ is the integral of the ${ }^{1} \mathrm{H}-\mathrm{NMR}$ feature for $\mathbf{1}^{\mathbf{O M e}}-(\mathbf{C O})_{2}$, relative to $\left[\mathrm{Fc}^{*}\right][\mathrm{OTf}]$ internal standard, which starts at $86.32 \mathrm{ppm}$ at $288 \mathrm{~K}$ and it is assumed that $100 \%$ of $\mathbf{1}^{\text {OMe }}$ has converted to $\mathbf{1}^{\mathbf{O M e}}-(\mathbf{C O})_{2}$ by $223 \mathrm{~K}$. $\mathrm{I}_{\mathrm{T}}$ is the integral relative to $\left[\mathrm{Fc}^{*}\right][\mathrm{OTf}]$ of this feature at the given temperature.

Van't Hoff analysis: $\quad \ln \left(K_{\mathrm{p}, 1}\right)=-\Delta H / \mathrm{RT}+\Delta S / \mathrm{R}$

Best Fit Line: $\ln \left(K_{\mathrm{p}, 1}\right)=-21.1(+/-0.4)+5349(+/-93) * 1 / \mathrm{T}$

Yields: $\quad \Delta H=-10.6(2) \mathrm{kcal} \mathrm{mol}^{-1}$

$\Delta S=-42(1) \mathrm{cal} \mathrm{mol}^{-1} \mathrm{~K}^{-1}$

$K_{\mathrm{p}, 1}(278 \mathrm{~K})=0.17 \mathrm{~atm}^{-1}$

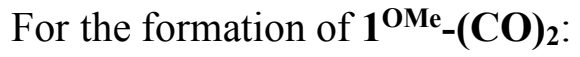

$$
\begin{gathered}
K_{\mathrm{p}, 2}=\left[1^{\text {OMe }}-(\mathbf{C O})_{2}\right] /\left[1^{\text {OMe }}-\mathrm{CO}\right]^{*} \mathrm{P}_{\mathrm{CO}} \\
\text { Where }\left[\mathbf{1}^{\text {OMe }}-\mathbf{C O}\right]=\left[\mathbf{1}^{\text {OMe }}-(\mathbf{C O})_{2}\right]_{\text {initial }}-\left[\mathbf{1}^{\text {OMe }}-(\mathbf{C O})_{2}\right]_{\text {equilibrium }}-\left[\mathbf{1}^{\text {OMe }}\right]_{\text {equilibrium }}
\end{gathered}
$$

Van't Hoff analysis:

$$
\ln \left(K_{\mathrm{p}, 2}\right)=-\Delta H / \mathrm{RT}+\Delta S / \mathrm{R}
$$

Best Fit Line: $\ln \left(K_{\mathrm{p}, 2}\right)=-17.5(+/-0.7)+4696(+/-171) * 1 / \mathrm{T}$

Yields: $\quad \Delta H=-9.3(3) \mathrm{kcal} \mathrm{mol}^{-1}$

$\Delta S=-35(1) \mathrm{cal} \mathrm{mol}^{-1} \mathrm{~K}^{-1}$

$$
K_{\mathrm{p}, 2}(278 \mathrm{~K})=0.49 \mathrm{~atm}^{-1}
$$




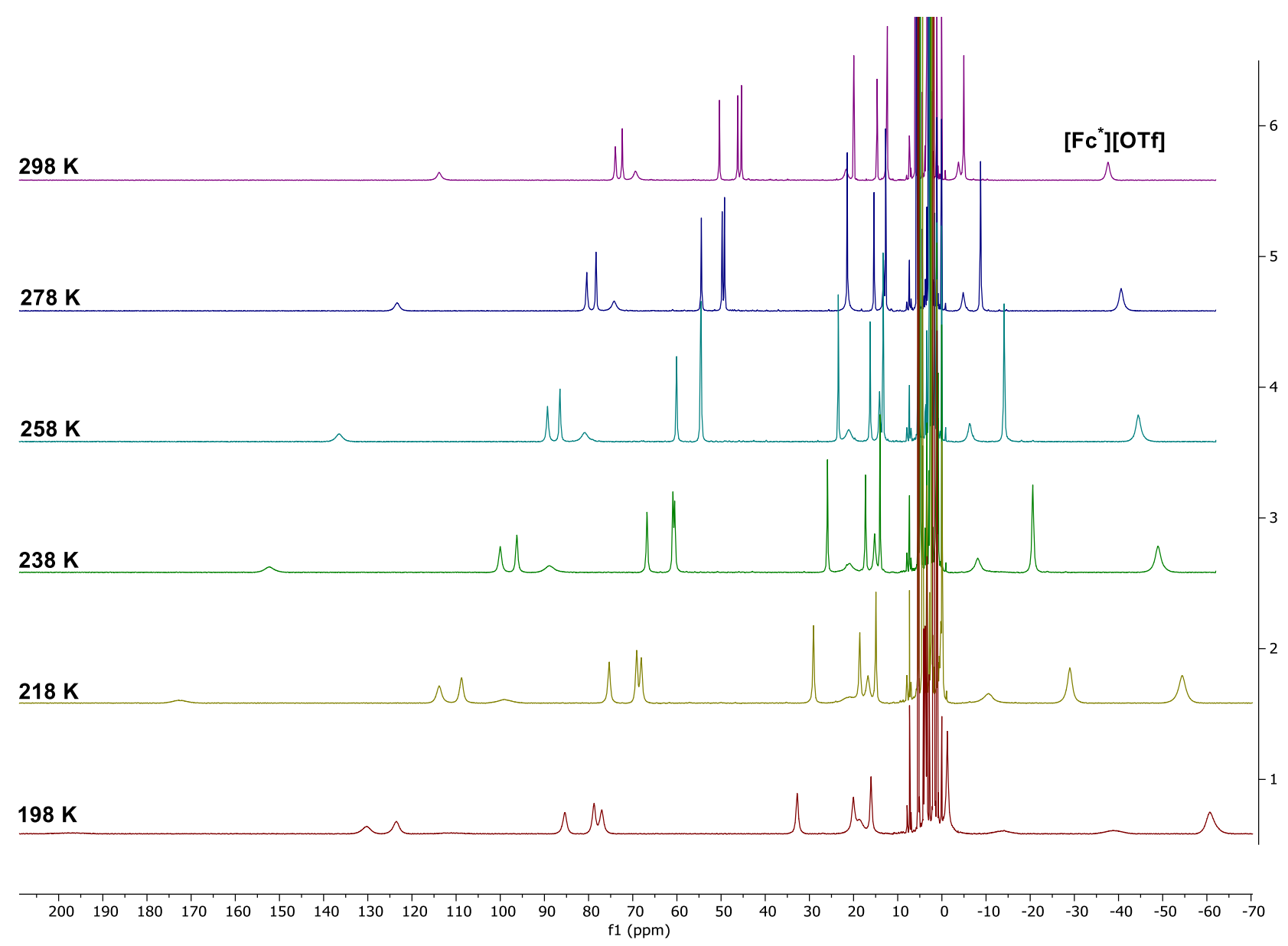

Figure S33. VT- ${ }^{1} \mathrm{H}$ NMR $(400 \mathrm{MHz})$ of $\left[\mathrm{LFe}_{3} \mathrm{O}\left({ }^{\mathrm{pOMe}} \mathrm{ArIm}\right){ }_{3} \mathrm{Fe}\right][\mathrm{OTf}]_{2}\left(\mathbf{1}^{\mathrm{OMe}}\right)$ in $\mathrm{CD}_{2} \mathrm{Cl}_{2}$ under $\mathrm{N}_{2}$ between $298 \mathrm{~K}$ (top) and $198 \mathrm{~K}$ (bottom) in $20 \mathrm{~K}$ intervals. 


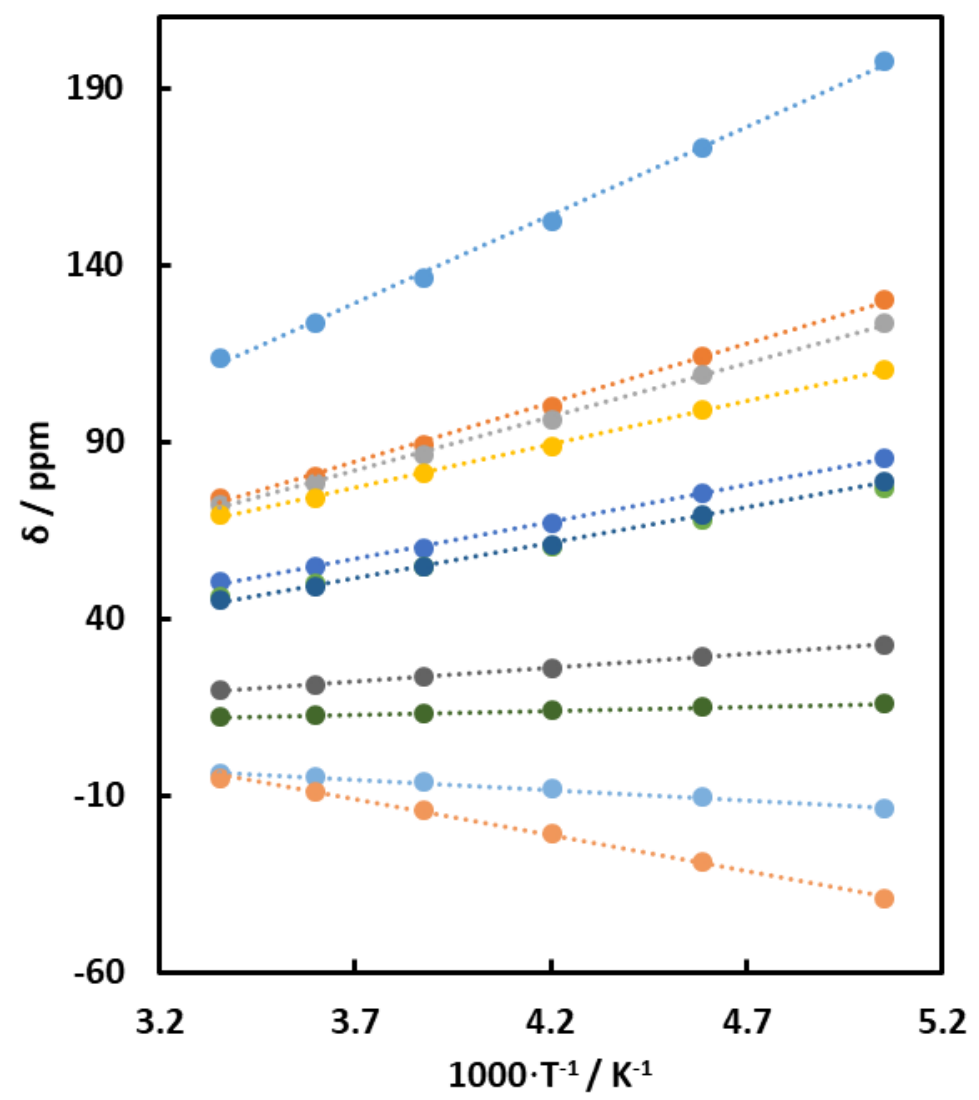

Figure S34. Curie plot showing the linear dependence (vs. the inverse temperature) of the ${ }^{1} \mathrm{H}$ chemical shift of selected protons (well resolved resonances) in $\left[\mathrm{LFe}_{3} \mathrm{O}\left({ }^{\mathrm{pOMe}} \mathrm{ArIm}\right)_{3} \mathrm{Fe}\right][\mathrm{OTf}]_{2}$ $\left(\mathbf{1}^{\mathbf{O M e}}\right)$ between 198 and $298 \mathrm{~K}$. The dashed lines are a guide to the eye. 


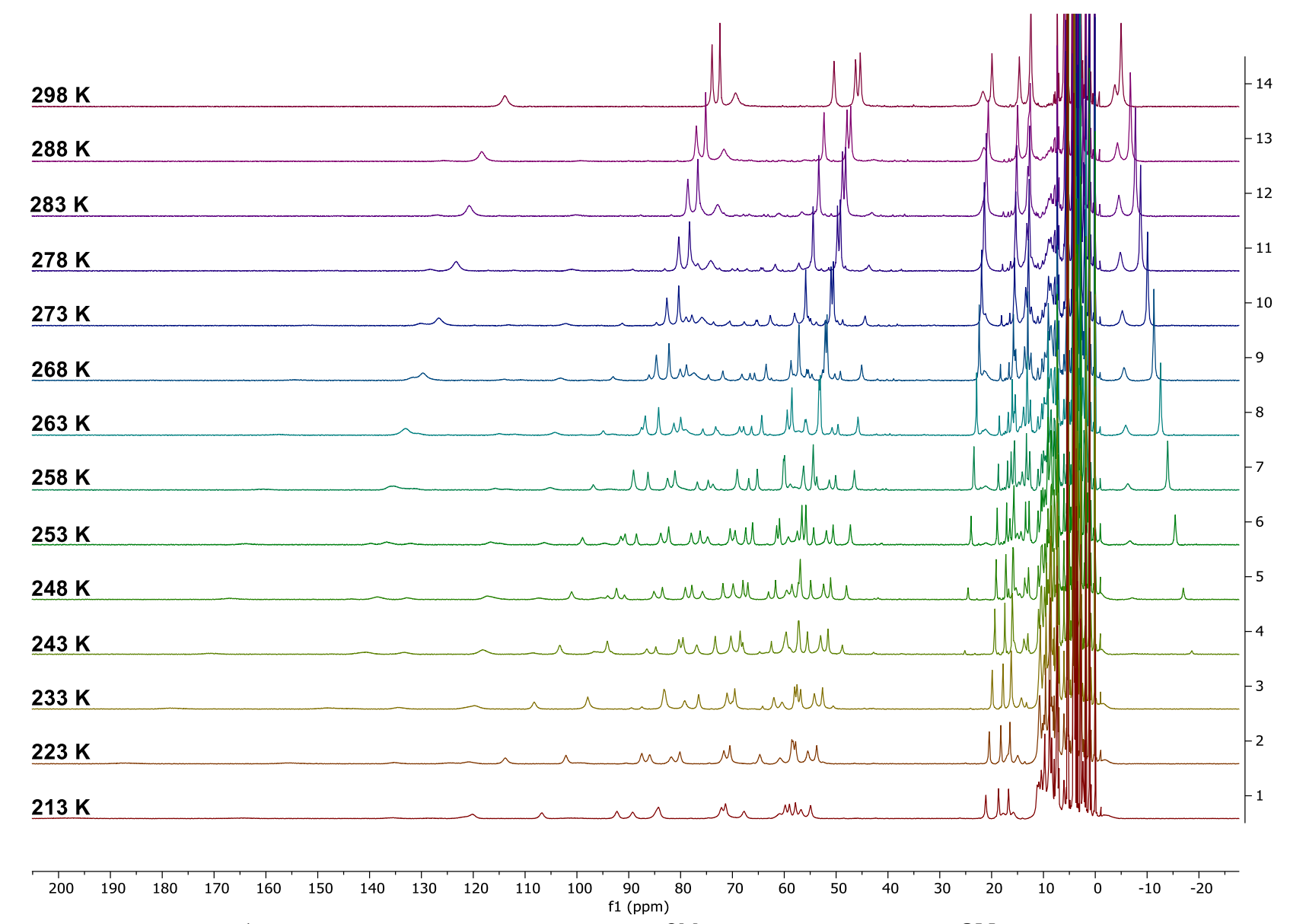

Figure S35. VT- ${ }^{1} \mathrm{H}$ NMR $(400 \mathrm{MHz})$ of $\left[\mathrm{LFe}_{3} \mathrm{O}\left({ }^{\mathrm{pOMe}} \mathrm{ArIm}\right)_{3} \mathrm{Fe}\right][\mathrm{OTf}]_{2}\left(\mathbf{1}^{\mathrm{OMe}}\right)$ in $\mathrm{CD}_{2} \mathrm{Cl}_{2}$ under CO (1 atm.) between $298 \mathrm{~K}$ (top) and $213 \mathrm{~K}$ (bottom). 


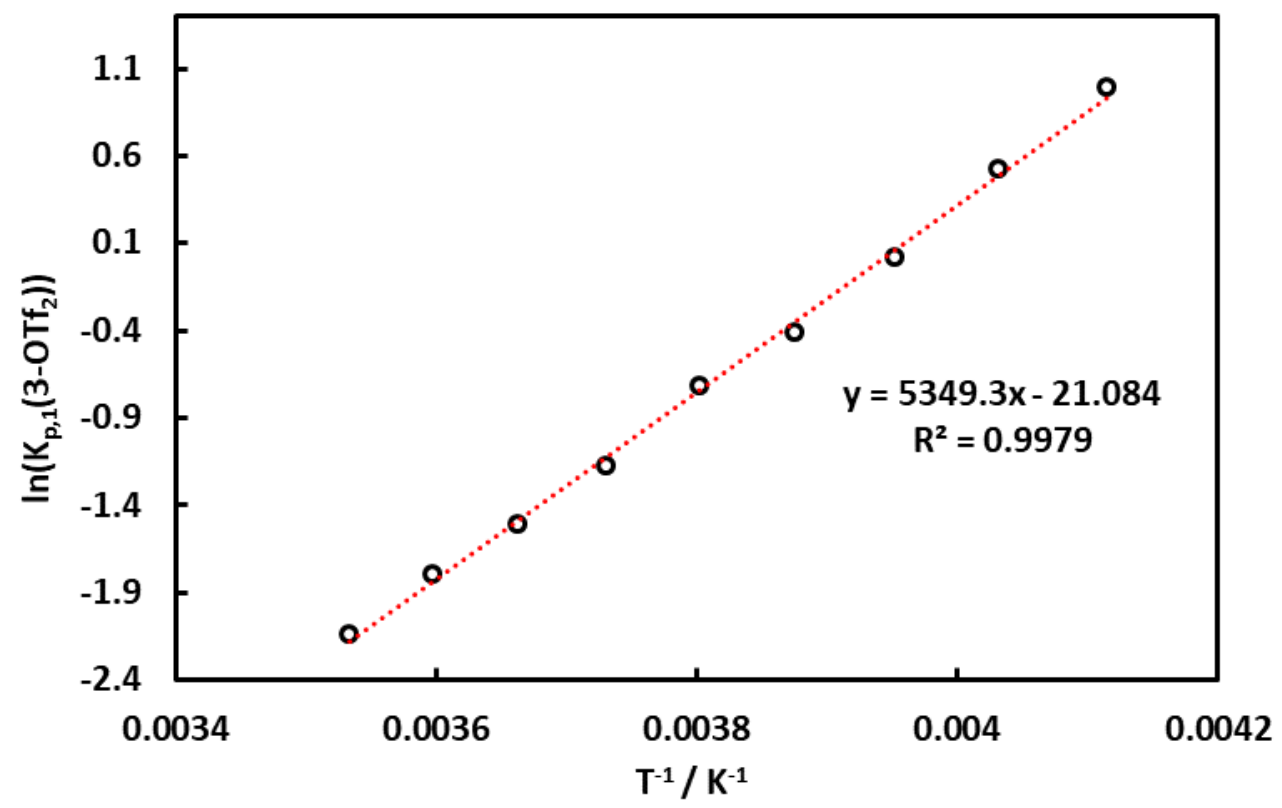

Figure S36. Van't Hoff plot for the formation of $\mathbf{1}^{\mathrm{OMe}}-\mathbf{C O}$ in dichloromethane- $d_{2}$ between 243$283 \mathrm{~K}$.

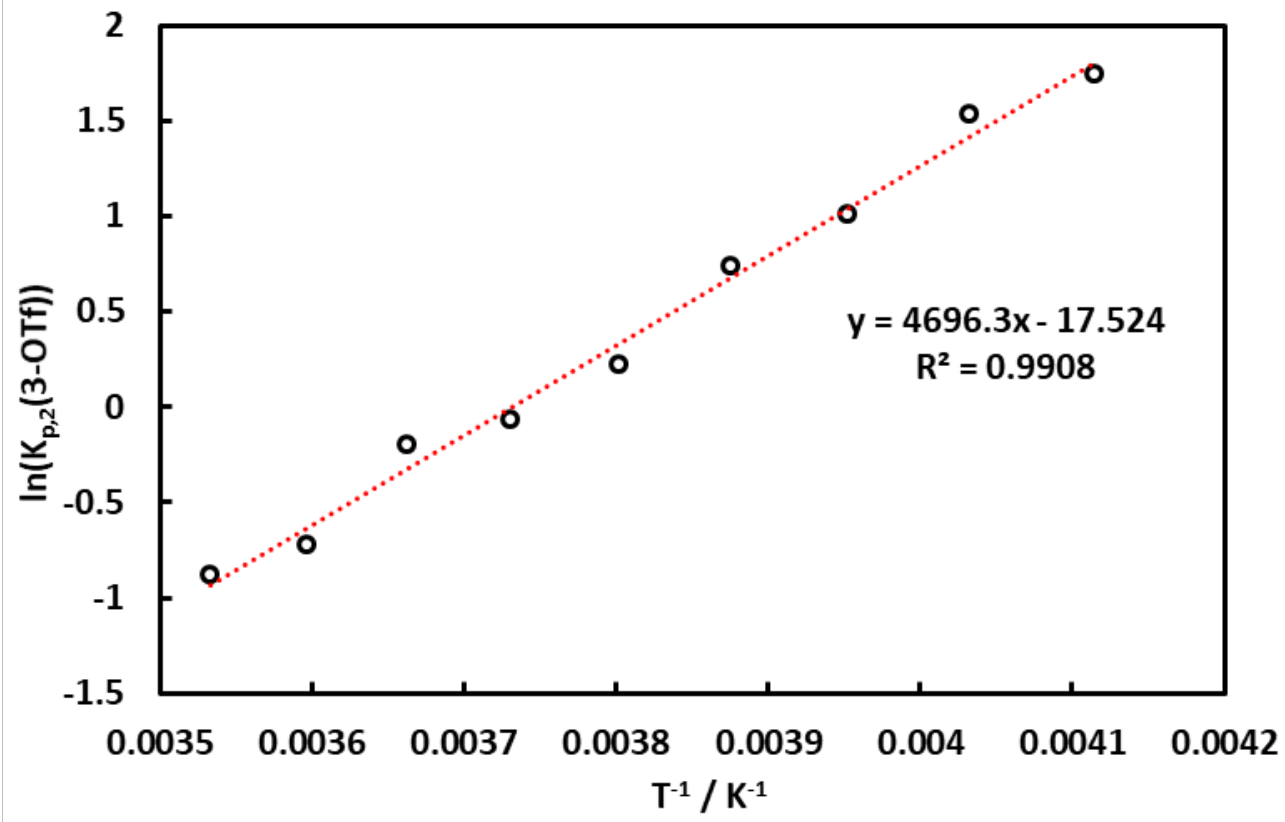

Figure S37. Van't Hoff plot for the formation of $\mathbf{1}^{\mathbf{O M e}}-(\mathbf{C O})_{2}$ in dichloromethane- $d_{2}$ between 243-283 K. 
Thermodynamics of CO Binding to $\left[\mathrm{LFe}_{3} \mathrm{O}\left(\mathrm{PNMe}^{\mathrm{NN}} \mathrm{ArIm}\right)_{3} \mathrm{Fe}\right][\mathrm{OTf}]_{2}\left(\mathbf{1}^{\mathrm{NMe} 2}\right)$ in dichloromethane- $d_{2}$ A stock solution of $\left[\mathrm{LFe}_{3} \mathrm{O}\left({ }^{\left({ }^{\mathrm{NMe}} 2\right.} \mathrm{ArIm}\right)_{3} \mathrm{Fe}\right][\mathrm{OTf}]_{2}\left(\mathbf{1}^{\mathrm{NMe} 2}\right)$ was prepared by dissolving $8.4 \mathrm{mg}$ of $\left[\mathrm{LFe}_{3} \mathrm{O}\left({ }^{\left(\mathrm{PNMe}^{2}\right.} \mathrm{ArIm}\right)_{3} \mathrm{Fe}\right][\mathrm{OTf}]_{2}\left(\mathbf{1}^{\mathrm{NMe} 2}\right)$ in $0.50 \mathrm{~mL}$ dry $\mathrm{CD}_{2} \mathrm{Cl}_{2}$. A stock solution of [ $\left[\mathrm{Fc}^{*}\right][\mathrm{OTf}]$ was prepared by dissolving $8.8 \mathrm{mg}$ in $1.00 \mathrm{~mL} \mathrm{CD}_{2} \mathrm{Cl}_{2}$. A $0.05 \mathrm{~mL}$ aliquot of the [ $\left.\mathrm{Fc}^{*}\right]$ [OTf] stock solution was transferred to a capillary and flame sealed. An aliquot $(0.35 \mathrm{~mL})$ of the $\left[\mathrm{LFe}_{3} \mathrm{O}\left(\mathrm{PNMe}^{\mathrm{NN}} \mathrm{ArIm}\right)_{3} \mathrm{Fe}\right][\mathrm{OTf}]_{2}\left(\mathbf{1}^{\mathrm{NMe2}}\right)$ stock solution and the sealed $\left[\mathrm{Fc}^{*}\right][\mathrm{OTf}]$ capillary were transferred to a J. Young tube. After recording the ${ }^{1} \mathrm{H}-\mathrm{NMR}$ spectrum in the absence of $\mathrm{CO}$, the solution was degassed by three freeze-pump-thaw cycles and then CO (1 atm.) was admitted at $293 \mathrm{~K}$ and spectra were then recorded between $223-298 \mathrm{~K}$. Separately, the VT- ${ }^{1} \mathrm{H}$ NMR spectrum of $\left[\mathrm{LFe}_{3} \mathrm{O}\left({ }^{\mathrm{pNMe} 2} \mathrm{ArIm}\right)_{3} \mathrm{Fe}\right][\mathrm{OTf}]_{2}\left(\mathbf{1}^{\mathrm{NMe}}\right)$ was measured under $\mathrm{N}_{2}$.

For the formation of $\mathbf{1}^{\mathrm{NMe} 2}-(\mathrm{CO})_{2}$ :

$$
\begin{gathered}
K_{\mathrm{p}}=\left[\mathbf{1}^{\mathrm{NMe} 2}-(\mathrm{CO})_{2}\right] /\left[\mathbf{1}^{\mathrm{NMe} 2}\right]^{* \mathrm{P}_{\mathrm{CO}}} \\
{\left[\mathbf{1}^{\mathrm{NMe} 2}-(\mathrm{CO})_{2}\right]=\left[\mathbf{1}^{\mathrm{NMe} 2}\right]_{\text {initial }}-\left[\mathbf{1}^{\mathrm{NMe} 2}\right]_{\text {equilibrium }}}
\end{gathered}
$$

The value of $\left[\mathbf{1}^{\mathrm{NMe} 2}\right]_{\text {equilibrium }}$ is determined according to:

$$
\left[\mathbf{1}^{\mathrm{NMe} 2}\right]_{\text {equilibrium }}=\left(\mathrm{I}_{\text {withCo }} / \mathrm{I}_{\mathrm{noCO}}\right) *\left[\mathbf{1}^{\mathrm{NMe} 2}\right]_{\text {initial }}
$$

Where $I_{\text {withCo }}$ and $\mathrm{I}_{\mathrm{noCO}}$ are the integrals of ${ }^{1} \mathrm{H}-\mathrm{NMR}$ feature for $\mathbf{1}^{\mathrm{NMe} 2}$ which starts at $-7.05 \mathrm{ppm}$ at $298 \mathrm{~K}$ in the presence or absence of $\mathrm{CO}$, respectively, all relative to [ $\left.\mathrm{Fc}^{*}\right][\mathrm{OTf}]$ internal standard.

Van't Hoff analysis: $\quad \ln \left(K_{\mathrm{p}}\right)=-\Delta H / \mathrm{RT}+\Delta S / \mathrm{R}$

Best Fit Line: $\ln \left(K_{\mathrm{p}}\right)=-44.3(+/-1.8)+11710(+/-462)^{*} 1 / \mathrm{T}$

Yields: $\quad \Delta H=-23.2(9) \mathrm{kcal} \mathrm{mol}^{-1}$

$\Delta S=-88(4) \mathrm{cal} \mathrm{mol}^{-1} \mathrm{~K}^{-1}$

$K_{\mathrm{p}}(278 \mathrm{~K})=0.13 \mathrm{~atm}^{-1}$ 


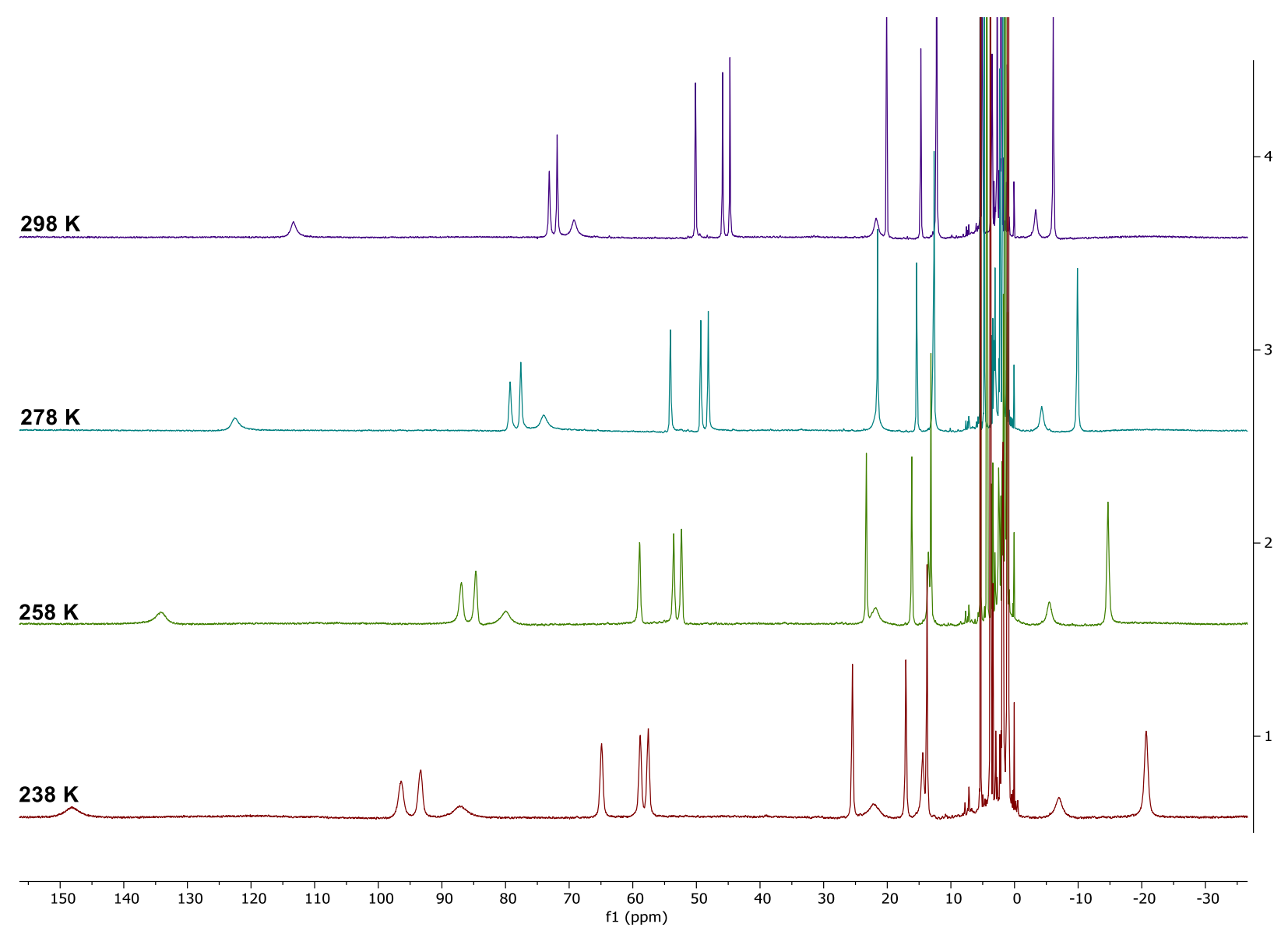

Figure S38. VT- ${ }^{1} \mathrm{H}$ NMR $(400 \mathrm{MHz})$ of $\left[\mathrm{LFe}_{3} \mathrm{O}\left({ }^{\mathrm{pNMe} 2} \mathrm{ArIm}\right){ }_{3} \mathrm{Fe}\right][\mathrm{OTf}]_{2}\left(\mathbf{1}^{\mathrm{NMe} 2}\right)$ in $\mathrm{CD}_{2} \mathrm{Cl}_{2}$ under $\mathrm{N}_{2}$ between $298 \mathrm{~K}$ (top) and $238 \mathrm{~K}$ (bottom) in $20 \mathrm{~K}$ intervals. 


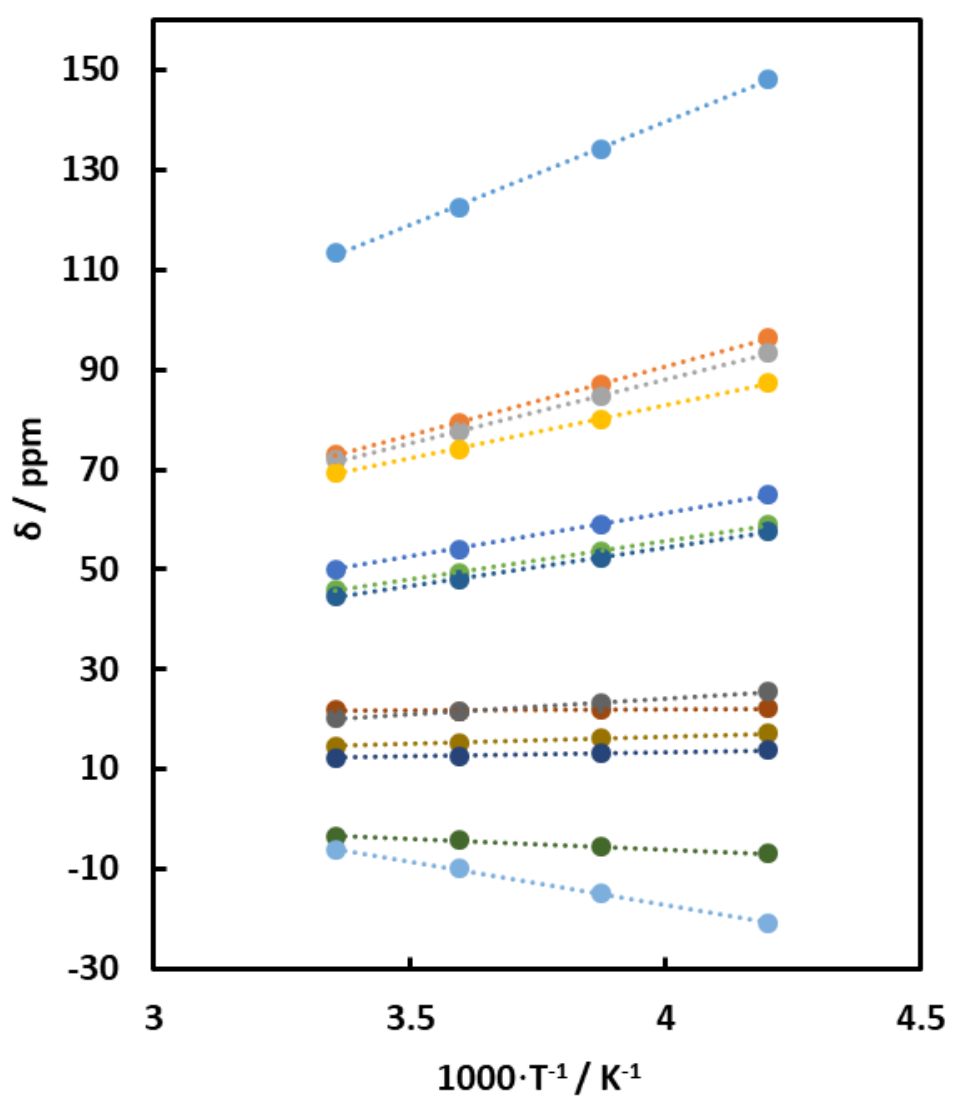

Figure S39. Curie plot showing the linear dependence (vs. the inverse temperature) of the ${ }^{1} \mathrm{H}$ chemical shift of selected protons (well resolved resonances) in $\left[\mathrm{LFe}_{3} \mathrm{O}\left({ }^{\mathrm{pNMe} 2} \mathrm{ArIm}\right)_{3} \mathrm{Fe}\right][\mathrm{OTf}]_{2}$ $\left(\mathbf{1}^{\mathrm{NMe} 2}\right)$ between 238 and $298 \mathrm{~K}$. The dashed lines are a guide to the eye. 


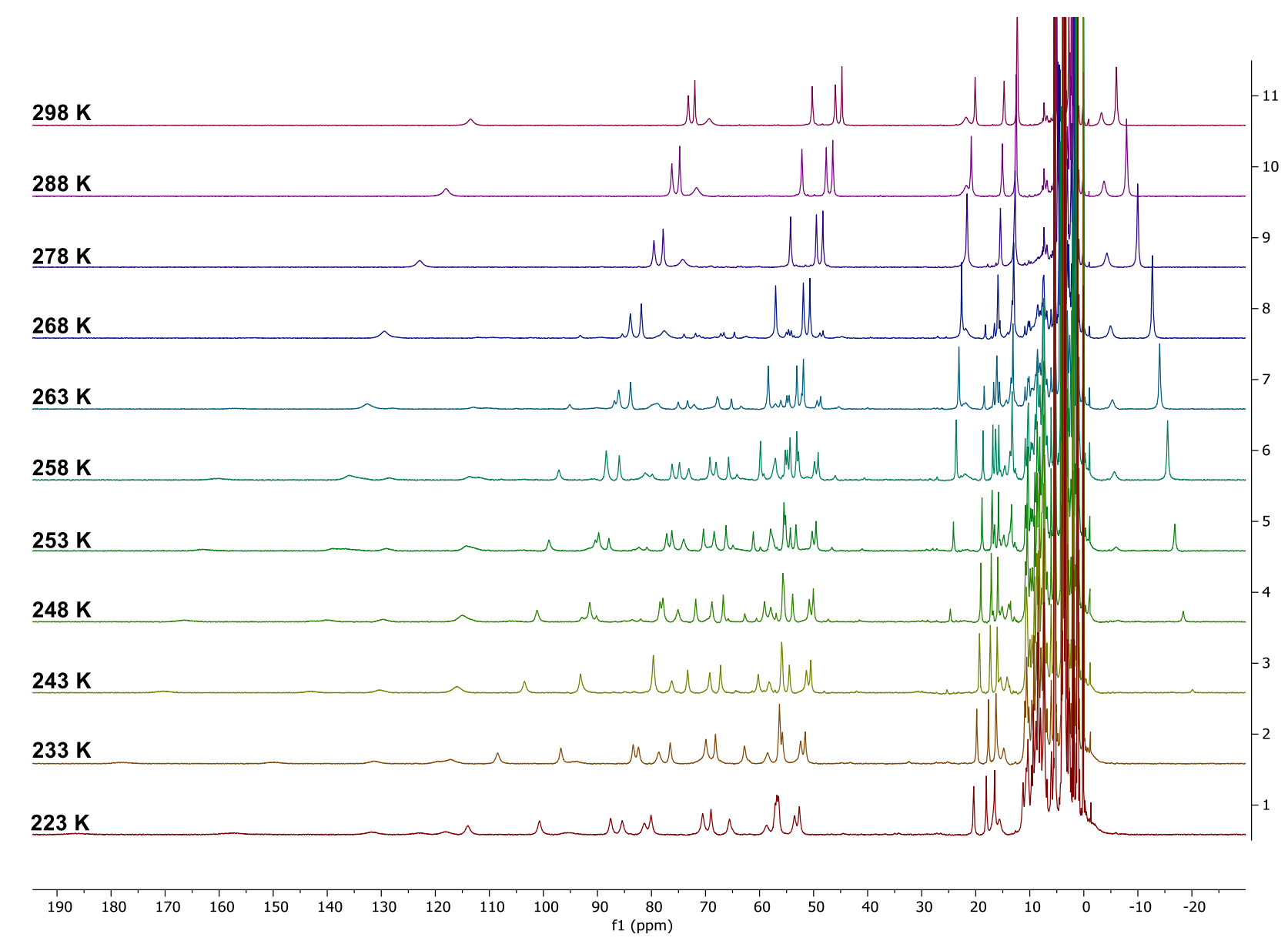

Figure S40. VT- ${ }^{1} \mathrm{H}$ NMR $(400 \mathrm{MHz})$ of $\left[\mathrm{LFe}_{3} \mathrm{O}\left({ }^{\mathrm{pNMe} 2} \mathrm{ArIm}\right){ }_{3} \mathrm{Fe}\right][\mathrm{OTf}]_{2}\left(\mathbf{1}^{\mathrm{NMe} 2}\right)$ in $\mathrm{CD}_{2} \mathrm{Cl}_{2}$ under CO (1 atm.) between $298 \mathrm{~K}$ (top) and $223 \mathrm{~K}$ (bottom). 


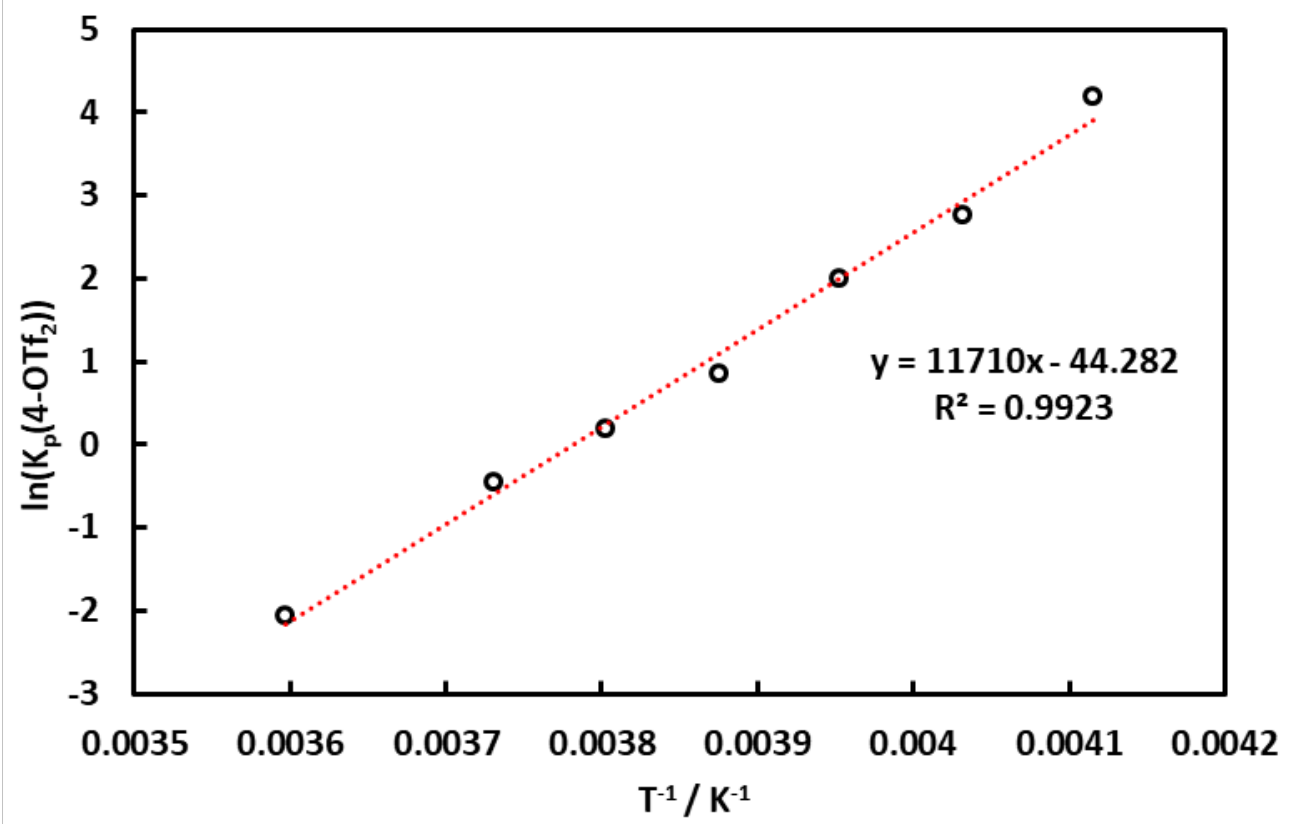

Figure S41. Van't Hoff plot for the formation of $\mathbf{1}^{\mathrm{NMe} 2}-(\mathbf{C O})_{2}$ in dichloromethane- $d_{2}$ between 243-278 K. 


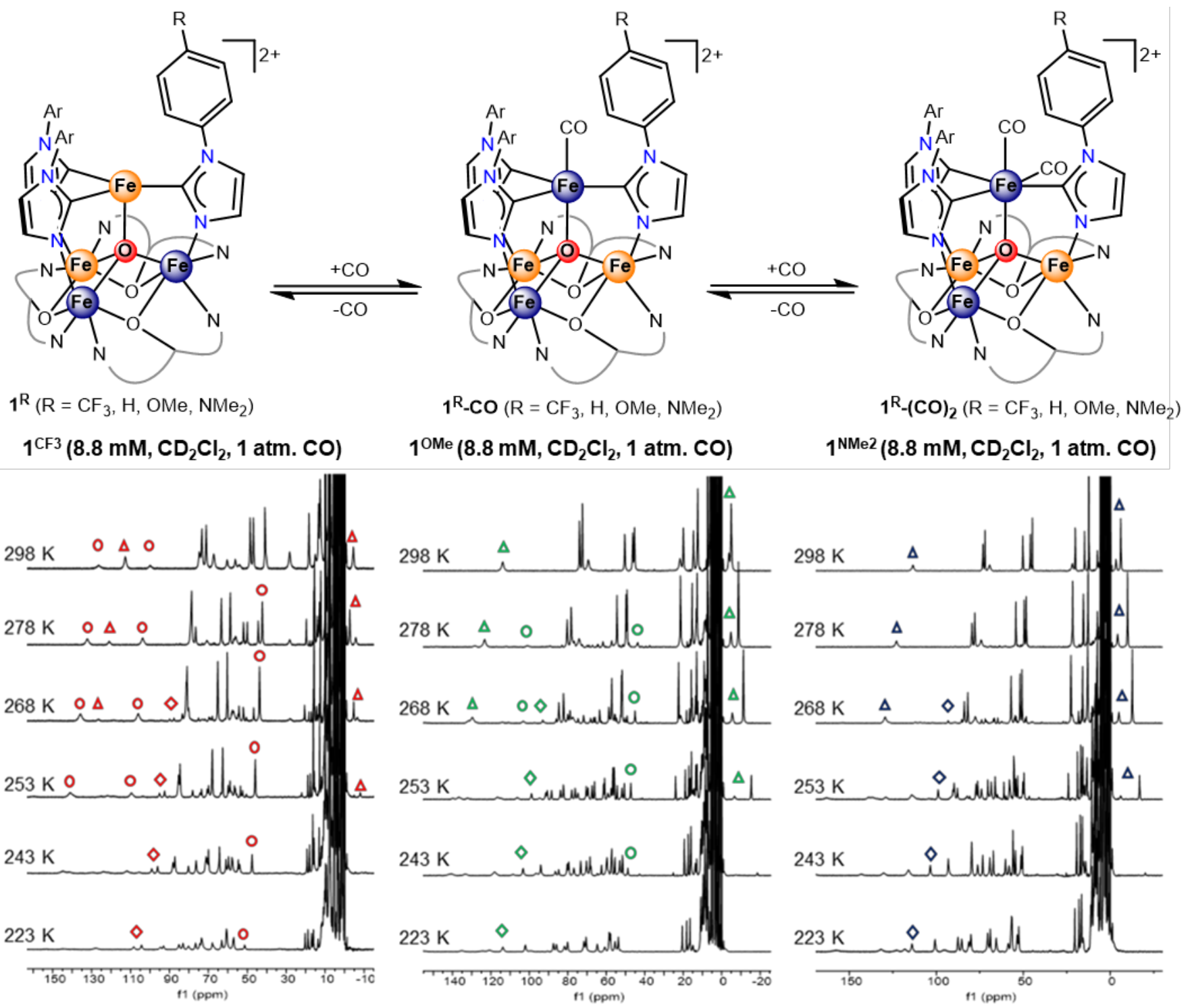

Figure S42. Variable temperature ${ }^{1} \mathrm{H}-\mathrm{NMR}$ spectroscopy illustrates the influence of ligand modifications on the affinity of $\mathbf{1}^{\mathbf{R}}\left(\mathrm{R}=\mathrm{CF}_{3}, \mathrm{H}, \mathrm{OMe}, \mathrm{NMe}_{2}\right)$ for binding one vs. two molecules of CO. Diagnostic spectral features: $\mathbf{1}^{\mathrm{R}}$ (triangles), $\mathbf{1}^{\mathrm{R}}-\mathbf{C O}$ (circles), $\left.\mathbf{1}^{\mathrm{R}}-\mathbf{C} \mathbf{C O}\right)_{2}$ (diamonds). 
Electrochemistry. The difference in $E_{1 / 2}$ values of adjacent electrochemical features $\left(\Delta E_{1 / 2}\right)$ is commonly referenced as a measure of the thermodynamic stabilization of mixed valence compounds that arises from electronic coupling. ${ }^{15}$ From this perspective, the large $\Delta E_{1 / 2}$ values (0.89-0.94 mV) observed for $\mathbf{1}^{\mathbf{R}}\left(\mathrm{R}=\mathrm{CF}_{3}, \mathrm{H}, \mathrm{OMe}, \mathrm{NMe}_{2}\right)$ in dichloromethane/0.1 $\mathrm{M}$ $\left[n \operatorname{Pr}_{4} \mathrm{~N}\right]\left[\mathrm{BAr}_{24}{ }_{24}\right]$ suggest extensive metal-metal interactions, seemingly incongruent with the valence localized description inferred from structural analysis and Mössbauer spectroscopy. Indeed, the comproportionation constants $\left(K_{\mathrm{c}}\right.$, where $\left.\Delta G_{\mathrm{c}}=-R T \ln K_{\mathrm{c}}=-n F \Delta E_{1 / 2}\right)$ for $\mathbf{1}^{\mathbf{R}}\left(\mathrm{R}=\mathrm{CF}_{3}\right.$, $\mathrm{H}, \mathrm{OMe}, \mathrm{NMe}_{2}$ ) are on the order of $10^{15}$, significantly larger than the commonly accepted limit $\left(K_{\mathrm{c}}>10^{7}\right)$ for a fully delocalized (class III) system. However, resonance stabilization of mixed valence compounds is only one factor that contributes to the magnitude of $\Delta E_{1 / 2}$ and, thus, $K_{\mathrm{c}}{ }^{16}$ Changes in solvent, electrolyte composition and/or the presence of ion-pairing can shift $\Delta E_{1 / 2}$ as much as $640 \mathrm{mV},{ }^{17-18}$ corresponding to variations in $K_{\mathrm{c}}$ of 10 orders of magnitude. To determine whether electrostatic contributions to $\Delta E_{1 / 2}$ for $\mathbf{1}^{\mathbf{R}}\left(\mathrm{R}=\mathrm{CF}_{3}, \mathrm{H}, \mathrm{OMe}, \mathrm{NMe}_{2}\right)$ are significant, cyclic voltammograms of $\mathbf{1}^{\mathrm{H}}$ in different solvents (dichloromethane, tetrahydrofuran, or acetone) and with different electrolyte compositions $\left(\left[n \mathrm{Pr}_{4} \mathrm{~N}\right]\left[\mathrm{BAr}_{24}\right], \mathrm{Na}\left[\mathrm{BAr}^{\mathrm{F}}{ }_{24}\right]\right.$, or $\left.\left[n \mathrm{Bu}_{4} \mathrm{~N}\right]\left[\mathrm{PF}_{6}\right]\right)$ can be compared. The resulting $\Delta E_{1 / 2}$ values are in fact dependent on the solvent and electrolyte used, with a minimum of $0.69 \mathrm{mV}\left(K_{\mathrm{c}} \sim 10^{11}\right)$ in acetone/0.1 $\mathrm{M}\left[n \mathrm{Bu}_{4} \mathrm{~N}\right]\left[\mathrm{PF}_{6}\right]$ (see Supporting Information of Ref. 5) and a maximum of $0.94 \mathrm{mV}\left(K_{\mathrm{c}} \sim 10^{15}\right)$ in dichloromethane/0.1 M $\left[n \operatorname{Pr}_{4} \mathrm{~N}\right]\left[\mathrm{BAr}_{24}{ }_{24}\right.$ (data reported herein). As such, the resonance contribution to $K_{\mathrm{c}}$ cannot be determined electrochemically and the extent of valence (de)localization is best determined by alternative methods.

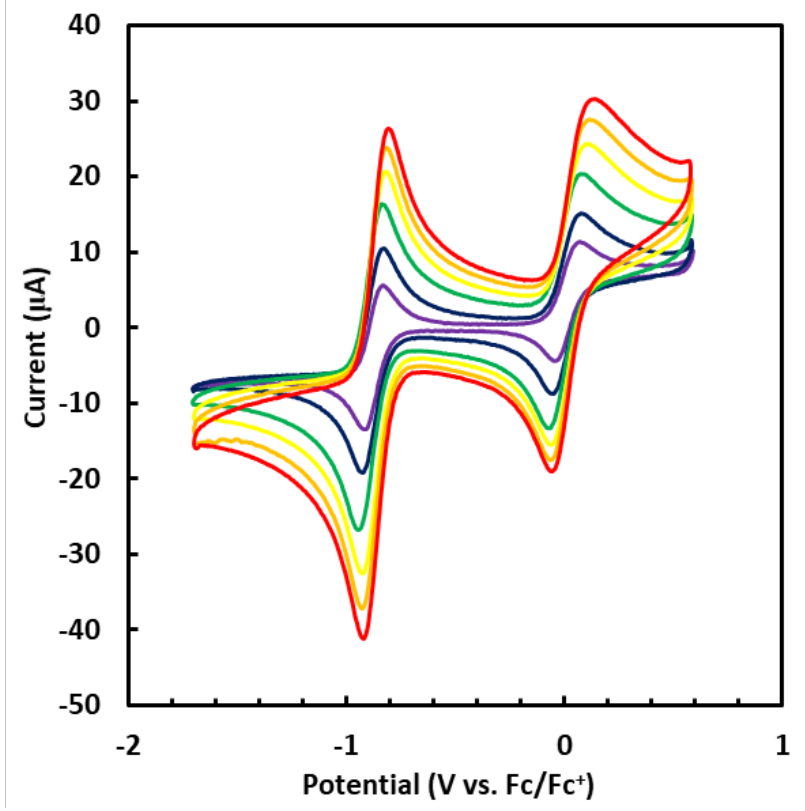

Figure S43. Scan rate dependence of the $\mathrm{CV}$ of $\left[\mathrm{LFe}_{3} \mathrm{O}\left({ }^{\mathrm{PCF} 3} \mathrm{ArIm}\right)_{3} \mathrm{Fe}\right][\mathrm{OTf}]_{2}\left(\mathbf{1}^{\mathrm{CF} 3}\right)$ in dichloromethane (0.1 M $\left.\left[n \mathrm{Pr}_{4} \mathrm{~N}\right]\left[\mathrm{BAr}^{\mathrm{F}}{ }_{24}\right]\right)$. 


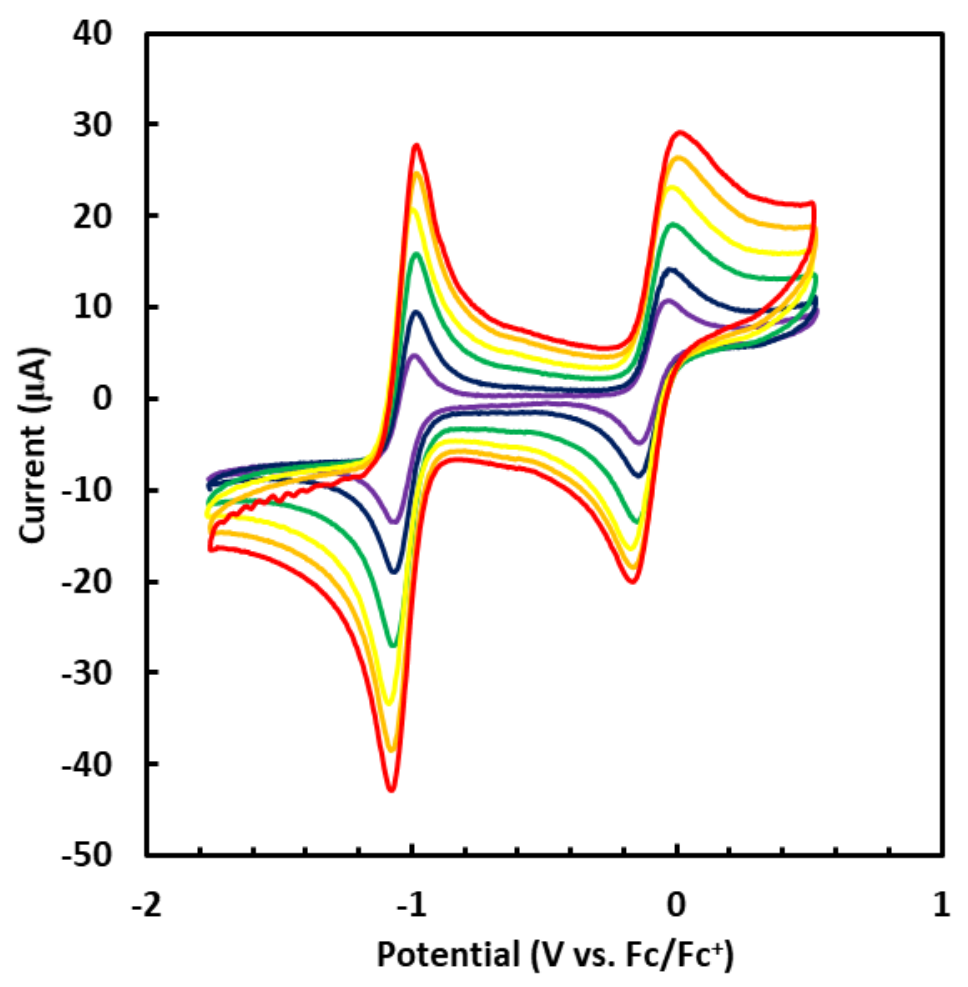

Figure S44. Scan rate dependence of the $\mathrm{CV}$ of $\left[\mathrm{LFe}_{3} \mathrm{O}(\mathrm{PhIm})_{3} \mathrm{Fe}\right][\mathrm{OTf}]_{2}\left(\mathbf{1}^{\mathbf{H}}\right)$ in dichloromethane $\left(0.1 \mathrm{M}\left[n \operatorname{Pr}_{4} \mathrm{~N}\right]\left[\mathrm{BAr}_{24}^{\mathrm{F}}\right]\right)$. 


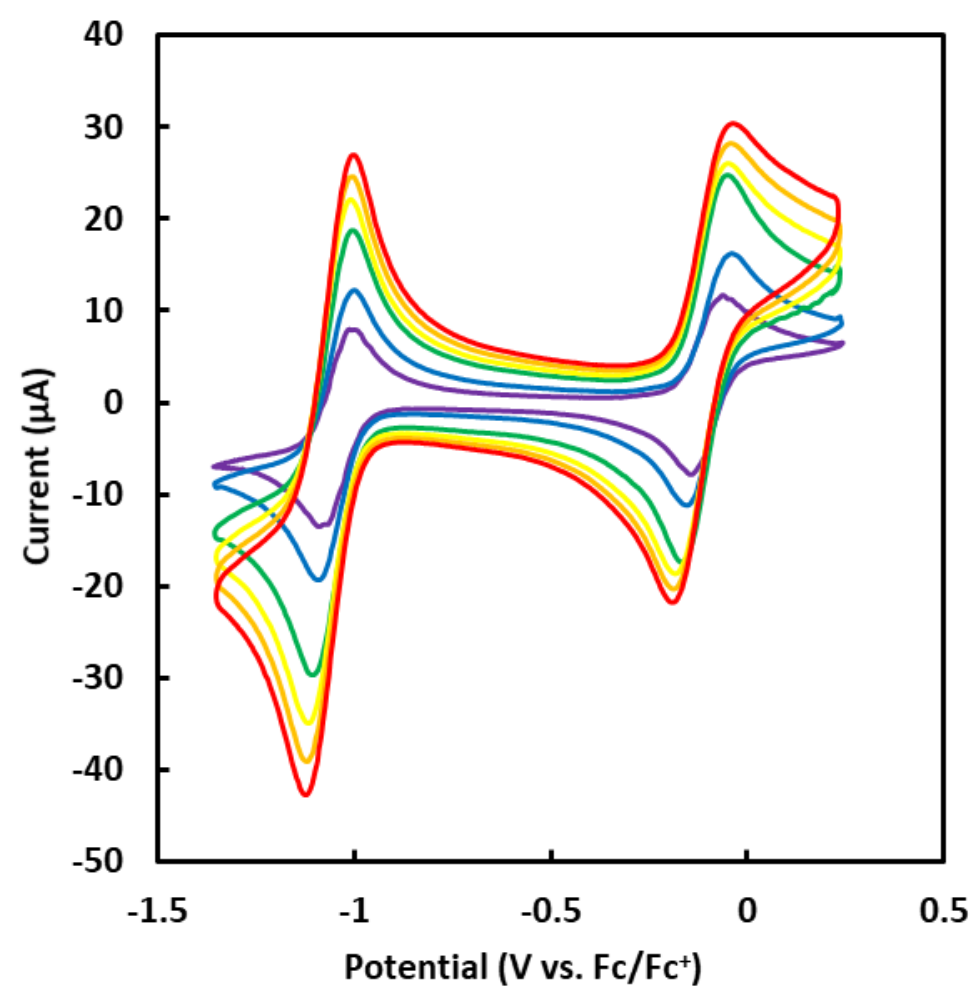

Figure S45. Scan rate dependence of the $\mathrm{CV}$ of $\left[\mathrm{LFe}_{3} \mathrm{O}\left({ }^{\mathrm{pOMe}} \mathrm{ArIm}\right)_{3} \mathrm{Fe}\right][\mathrm{OTf}]_{2}\left(\mathbf{1}^{\mathrm{OMe}}\right)$ in dichloromethane (0.1 $\left.\mathrm{M}\left[n \mathrm{Pr}_{4} \mathrm{~N}\right]\left[\mathrm{BAr}^{\mathrm{F}} 24\right]\right)$. 


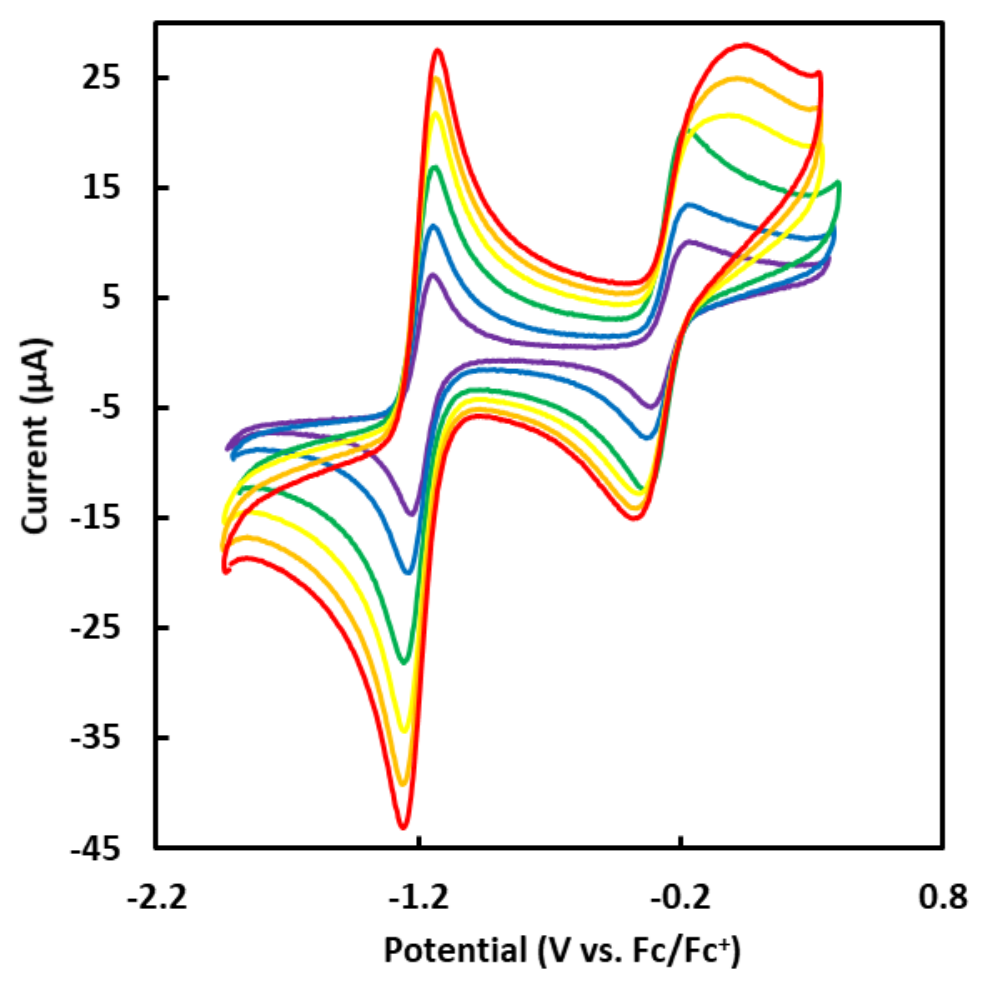

Figure S46. Scan rate dependence of the $\mathrm{CV}$ of $\left[\mathrm{LFe}_{3} \mathrm{O}\left({ }^{\mathrm{pNMe} 2} \mathrm{ArIm}\right)_{3} \mathrm{Fe}\right][\mathrm{OTf}]_{2}\left(\mathbf{1}^{\mathrm{NMe} 2}\right)$ in dichloromethane (0.1 $\left.\mathrm{M}\left[n \mathrm{Pr}_{4} \mathrm{~N}\right]\left[\mathrm{BAr}^{\mathrm{F}} 24\right]\right)$. 


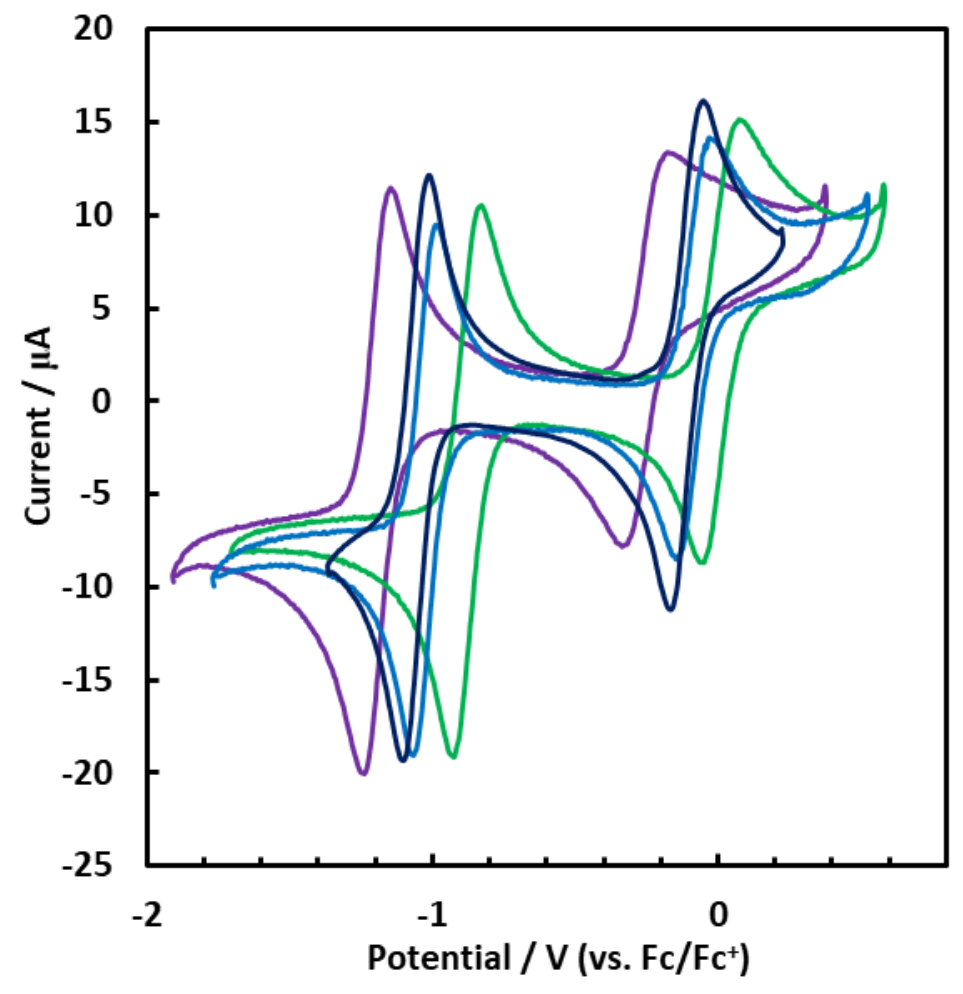

Figure S47. Comparison of $\mathrm{CV}$ data for $\left[\mathrm{LFe}_{3} \mathrm{O}\left({ }^{\mathrm{R}} \mathrm{ArIm}\right)_{3} \mathrm{Fe}\right][\mathrm{OTf}]_{2}\left(\mathbf{1}^{\mathbf{R}}\right)$ in dichloromethane $(0.1$ $\mathrm{M}\left[n \mathrm{Pr}_{4} \mathrm{~N}\right]\left[\mathrm{BAr}^{\mathrm{F}}{ }_{24}\right], 100 \mathrm{mV}$ scan rate) 


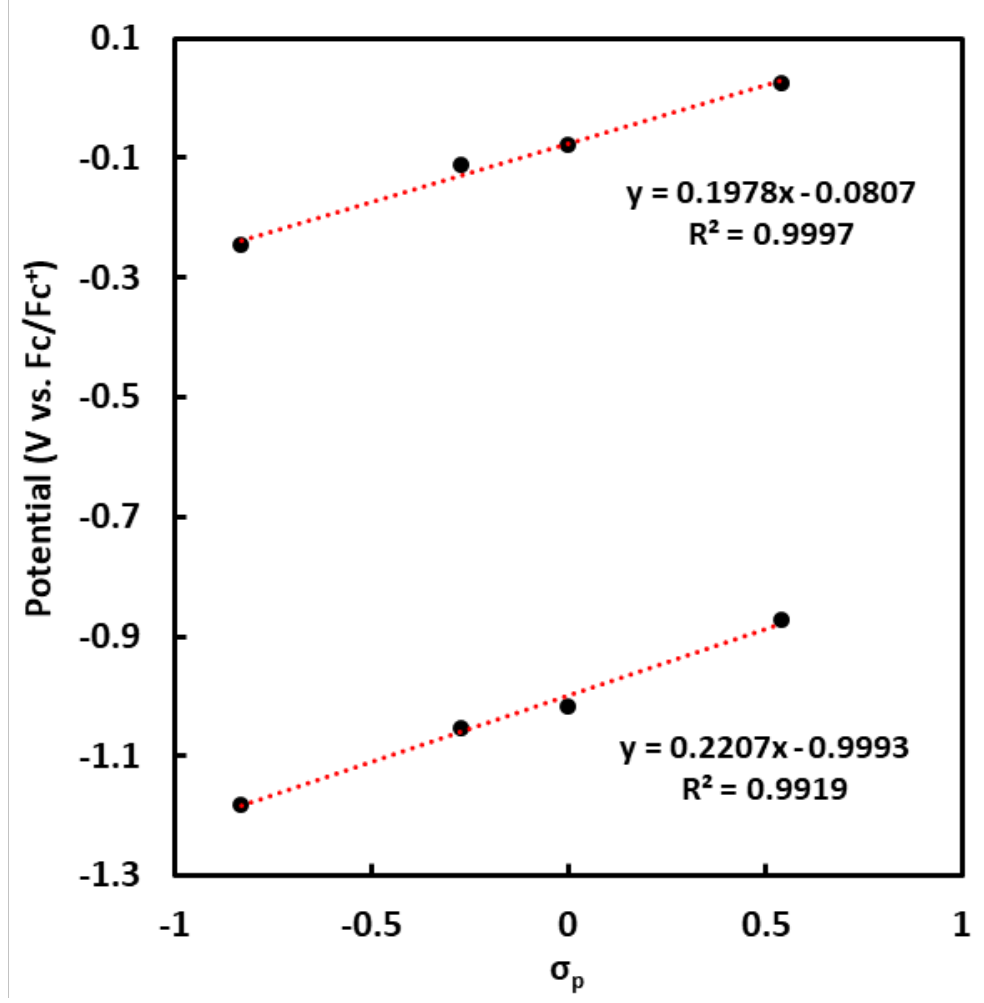

Figure S48. Correlation of $\mathrm{E}_{1 / 2}$ values for $\left[\mathrm{LFe}_{3} \mathrm{O}\left({ }^{\mathrm{R}} \mathrm{ArIm}\right)_{3} \mathrm{Fe}(\mathrm{CO})\right][\mathrm{OTf}]_{2}\left(\mathbf{1}^{\mathbf{R}}\right)$ with their Hammett substituent constants.

Table S2. Comparison of $\mathrm{E}_{1 / 2}$ values for $\left[\mathrm{LFe}_{3} \mathrm{O}\left({ }^{\mathrm{R}} \mathrm{ArIm}\right)_{3} \mathrm{Fe}\right][\mathrm{OTf}]_{2}\left(\mathbf{1}^{\mathbf{R}}\right)$ in dichloromethane $(0.1$ $\left.\mathrm{M}\left[n \mathrm{Bu}_{4} \mathrm{~N}\right]\left[\mathrm{BAr}^{\mathrm{F}}{ }_{24}\right]\right)$

\begin{tabular}{c|c|c|c|c} 
Redox Couple $\left(\mathrm{Vvs} . \mathrm{Fc} / \mathrm{Fc}^{+}\right)$ & $\mathrm{R}=\mathrm{NMe}_{2}$ & $\mathrm{R}=\mathrm{OMe}$ & $\mathrm{R}=\mathrm{H}$ & $\mathrm{R}=\mathrm{CF}_{3}$ \\
\hline $3+/ 2+$ & -0.25 & -0.11 & -0.08 & 0.02 \\
$2+/ 1+$ & -1.18 & -1.05 & -1.02 & -0.87 \\
$\Delta E$ & 0.93 & 0.94 & 0.94 & 0.89 \\
$K_{c}$ & $5.4 \mathrm{E}+15$ & $7.9 \mathrm{E}+15$ & $7.9 \mathrm{E}+15$ & $1.1 \mathrm{E}+15$
\end{tabular}




\section{Magnetic Measurements}

General Simulation Details. For mixed valent $\mathrm{Fe}(\mathrm{II}) / \mathrm{Fe}(\mathrm{III})$ pairs, the exchange coupling interaction is a superposition of superexchange $(J)$ and double exchange $(B)$ interactions. ${ }^{19-20}$ For the clusters under study here, a complete description of the magnetic properties would require determination of up to 10 exchange parameters ( $6 \mathrm{~J}$ values and up to $4 \mathrm{~B}$ values). However, these parameters cannot be uniquely defined from the experimental susceptibility data. Alternatively, the experimental data can be simulated by employing effective exchange coupling constants $\left(J_{\text {eff }}\right)$ which include contributions from both superexchange and double exchange, reducing the number of unknowns to 6 . Moreover, based on the pseudosymmetry observed in the solid state structure (related to the symmetry of the distribution of redox states), further contraints can be imposed on the values of these effective exchange coupling constants which greatly enhance the uniqueness of the obtained fits. While magnetostructural correlations for iron clusters with nuclearity $\geq 3$ are largely limited to the all-ferric redox state, ${ }^{21-30}$ which is not complicated by the presence of double exchange or anisotropic interactions arising from inequivalent population of the d-orbital manifold, the effective exchange coupling constants obtained herein are qualitatively reasonable. The presence of weak exchange coupling within the triiron core $\left(\left|J_{\text {eff }}\right| \leq 12 \mathrm{~cm}^{-1}\right)$ is consistent with previous magnetic studies $\mathrm{LFe}_{3}(\mathrm{OAc})_{3}{ }^{31}$ and oxo/alkoxo bridged diiron systems. ${ }^{21,32-35}$ Complexes featuring pyrazolate bridged $\mathrm{Fe}^{\mathrm{III}}{ }_{3}\left(\mu_{3}-\mathrm{O}\right)$ cores exhibit antiferromagnetic exchange couplings of $J$ $\sim-30$ to $-40 \mathrm{~cm}^{-1},{ }^{24,27,36}$ with the larger $|J|$ values reported herein attributed to the short Fe4-O1 distance and enhanced covalency within the Fe4-imidazolate-Fe(1/2/3) units (see DFT computations in Ref. 5). Moreover, the exchange coupling constants derived from simulations of the susceptibility data reported herein generally follow the trend that $|J|\left(\mathrm{Fe}^{\mathrm{III}}-\mathrm{Fe}^{\mathrm{III}}\right)>|J|\left(\mathrm{Fe}^{\mathrm{II}}-\mathrm{Fe}^{\mathrm{III}}\right)$ $>|J|\left(\mathrm{Fe}^{\mathrm{II}}-\mathrm{Fe}^{\mathrm{II}}\right)$, which we attribute to elongation of the $\mathrm{Fe}-\mathrm{O} 1$ distances upon reduction and the effect of double exchange in the mixed valence pairs. Numerical subscripts were chosen to be consistent with atom labels in the crystal structures.

\section{Simulation Details for $\quad\left[\mathrm{LFe}_{3} \mathrm{O}\left({ }^{\mathrm{PCF}} \mathrm{ArIm}\right)_{3} \mathrm{Fe}\right][\mathrm{OTf}]_{2} \quad{\left(1^{\mathrm{CF} 3}\right) \quad \text { and }}$} $\left[\mathrm{LFe}_{3} \mathrm{O}\left({ }^{\mathbf{p N M}^{\mathrm{NM}}} \mathrm{ArIm}\right)_{3} \mathbf{F e}\right][\mathrm{OTf}]_{2} \quad\left(\mathbf{1}^{\mathrm{NMe}}\right)$ : Variable temperature magnetic susceptibility data obtained between $1.8 \mathrm{~K}$ and $300 \mathrm{~K}$ at $0.1 \mathrm{~T}$ suggest that this is indeed the case. The values of $\chi_{M} \mathrm{~T}$ at $300 \mathrm{~K}\left(\mathbf{1}^{\mathbf{C F 3}}: 6.96 \mathrm{~cm}^{3} \mathrm{~K} \mathrm{~mol}^{-1}, \mathbf{1}^{\mathrm{NMe} 2}: 6.25 \mathrm{~cm}^{3} \mathrm{~K} \mathrm{~mol}^{-1}\right)$ deviate significantly from the spinonly value $\left(14.75 \mathrm{~cm}^{3} \mathrm{~K} \mathrm{~mol}^{-1}\right)$ anticipated for uncoupled $\mathrm{Fe}^{\mathrm{II}}(S=2)$ and $\mathrm{Fe}^{\mathrm{III}}(S=5 / 2)$ centers, indicating the presence of antiferromagnetic coupling. However, $\chi_{M} \mathrm{~T}$ increases gradually as the temperature is lowered, eventually reaching a plateau $\left(\mathbf{1}^{\mathbf{C F} 3}: \sim 8.8 \mathrm{~cm}^{3} \mathrm{~K} \mathrm{~mol}^{-1}, \mathbf{1}^{\text {NMe2}}\right.$ : $\sim 9.3 \mathrm{~cm}^{3} \mathrm{~K}$ $\left.\mathrm{mol}^{-1}\right)$ near the expected spin-only value for an isolated $S=4$ center $\left(10 \mathrm{~cm}^{3} \mathrm{~K} \mathrm{~mol}{ }^{-1}\right)$. The qualitative differences in the $\chi_{M} T$ curves, namely the higher moment at $300 \mathrm{~K}$ for $\mathbf{1}^{\mathbf{C F} 3}$, its more gradual rise, and its smaller low temperature plateau value, suggest that the antiferromagnetic interaction of the apical $\mathrm{Fe}^{\mathrm{III}}$ with $\mathrm{Fe} 1 / \mathrm{Fe} 2 / \mathrm{Fe} 3$ is weaker in $\mathbf{1}^{\mathbf{C F 3}}$ compared to $\mathbf{1}^{\mathbf{N M e} 2}$. A similar observation was made by Jackson and Nocera, who showed that electron donating parasubstituents enhance the antiferromagnetic coupling of $\mathrm{V}^{\mathrm{IV}}$ centers in layered vanadyl phosphonates. ${ }^{37}$ Simulations of the experimental data for $\mathbf{1}^{\mathbf{C F} 3}$ and $\mathbf{1}^{\mathbf{N M e} 2}$ according to the spin Hamiltonian $H=\sum\left\{D\left(S_{z, i}{ }^{2}-1 / 3\left(S_{i}\left(S_{i}+1\right)+g \mu_{B} S_{i} \cdot H\right)\right\}-2 J_{i j}\left(S_{i} \cdot S_{j}\right)\right.$ reflect this trend, most notably in the value of the apical Fe ${ }^{\mathrm{III}}$-core Fe $\mathrm{FII}^{\mathrm{III}}$ exchange coupling constant $\left(\mathbf{1}^{\mathrm{CF}}: J_{24}=-32.2 \mathrm{~cm}^{-1} ; \mathbf{1}^{\mathrm{NMe}}\right.$ : $J_{24}=-69.4 \mathrm{~cm}^{-1}$ ). Consistent with the assignment of Fe4 in $\mathbf{1}^{\mathrm{CF} 3}$ as $\mathrm{Fe}^{\mathrm{III}}$, the coupling of the apical iron center with the core iron centers is much stronger than the coupling between the iron centers in the triiron core. While a satisfactory fit to the low temperature susceptibility data required 
inclusion of single ion zero-field splitting, the relative magnitude of the exchange coupling constants $\left(\left|J_{\text {core-core }}\right|<<\left|J_{\text {apical-core }}\right|\right)$ obtained were not significantly affected. Based on these parameters, strong antiferromagnetic interactions of the apical $\mathrm{Fe}^{\mathrm{III}}(\mathrm{Fe} 4)$ with each of the metal centers of the triiron core results in ferromagnetic alignment of the spins on $\mathrm{Fe} 1 / \mathrm{Fe} 2 / \mathrm{Fe} 3$ at low temperatures, affording an $S=4$ ground state.

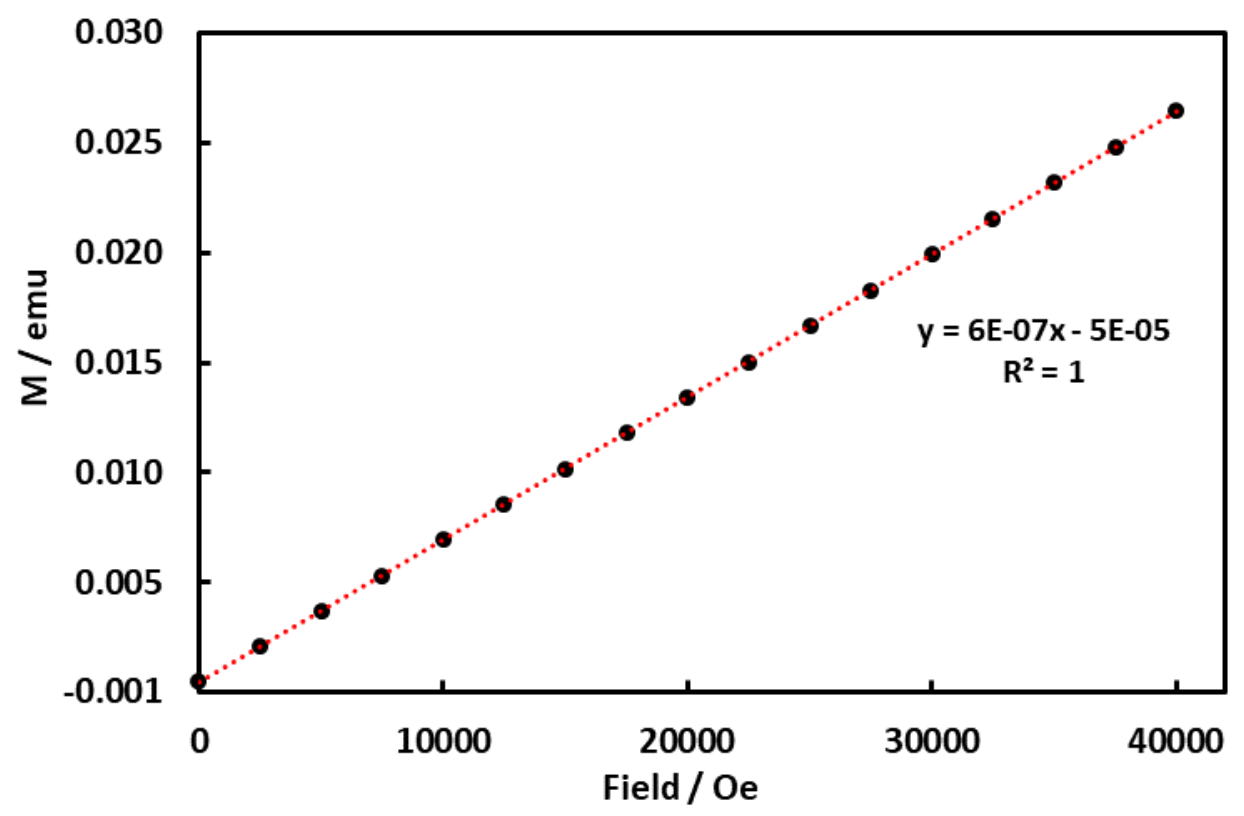

Figure S49. Magnetization data collected at $100 \mathrm{~K}$ from 0 to $4 \mathrm{~T}$ for $\left[\mathrm{LFe}_{3} \mathrm{O}\left({ }^{\mathrm{pCF}} \mathrm{ArIm}\right)_{3} \mathrm{Fe}\right][\mathrm{OTf}]_{2}\left(\mathbf{1}^{\mathbf{C F} 3}\right)$ to confirm the absence of ferromagnetic impurities.

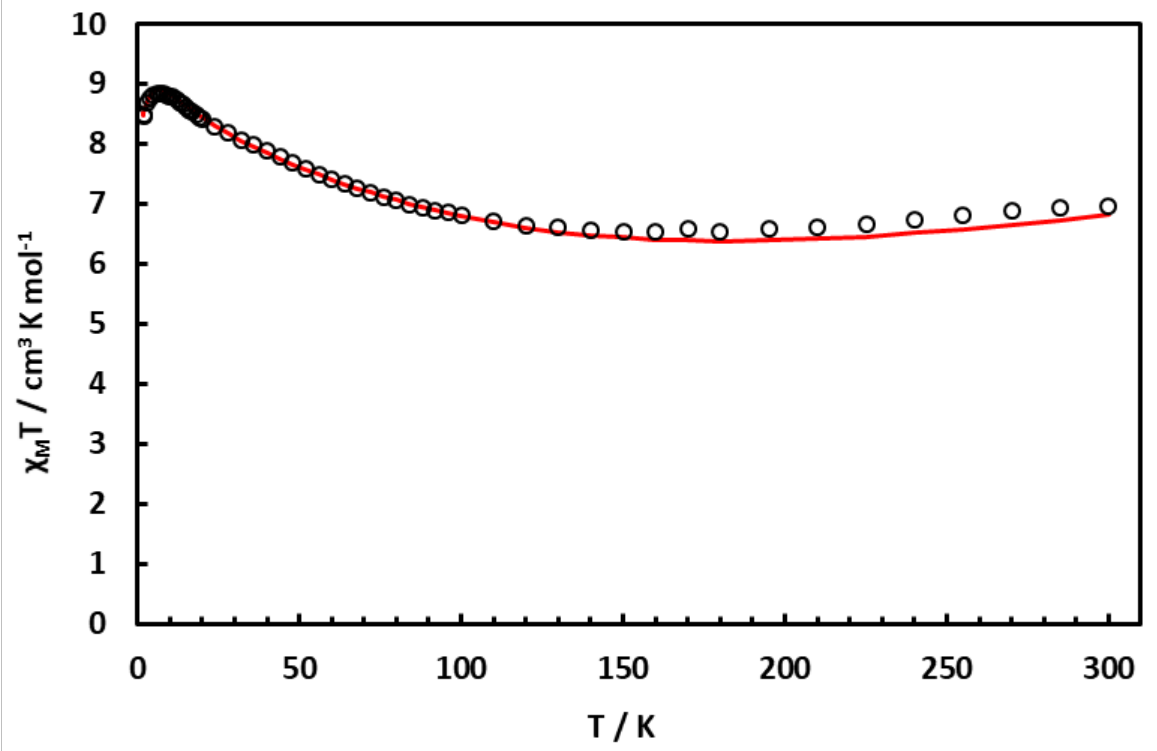

Figure S50. Direct current variable temperature magnetic susceptibility measurements for $\left[\mathrm{LFe}_{3} \mathrm{O}\left({ }^{\mathrm{pCF}} \mathrm{ArIm}\right)_{3} \mathrm{Fe}\right][\mathrm{OTf}]_{2}\left(\mathbf{1}^{\mathbf{C F} 3}\right)$ collected between 1.8 and $300 \mathrm{~K}$ with a $0.1 \mathrm{~T}$ field after diamagnetic correction (black circles). Full Fit parameters: $S_{1}=S_{3}=2, S_{2}=S_{4}=5 / 2 ; g_{1}=g_{2}=$ $g_{3}=g_{4}=2.00 ;\left|D_{1}\right|=\left|D_{3}\right|=0.77 \mathrm{~cm}^{-1},\left|D_{2}\right|=1.99 \mathrm{~cm}^{-1},\left|D_{4}\right|=1.96 \mathrm{~cm}^{-1} ; J_{14}=J_{34}=-22.7 \mathrm{~cm}^{-1}, J_{24}$ $=-32.2 \mathrm{~cm}^{-1}, J_{12}=J_{23}=-0.1 \mathrm{~cm}^{-1}, J_{13}=-13.5 \mathrm{~cm}^{-1}$. 


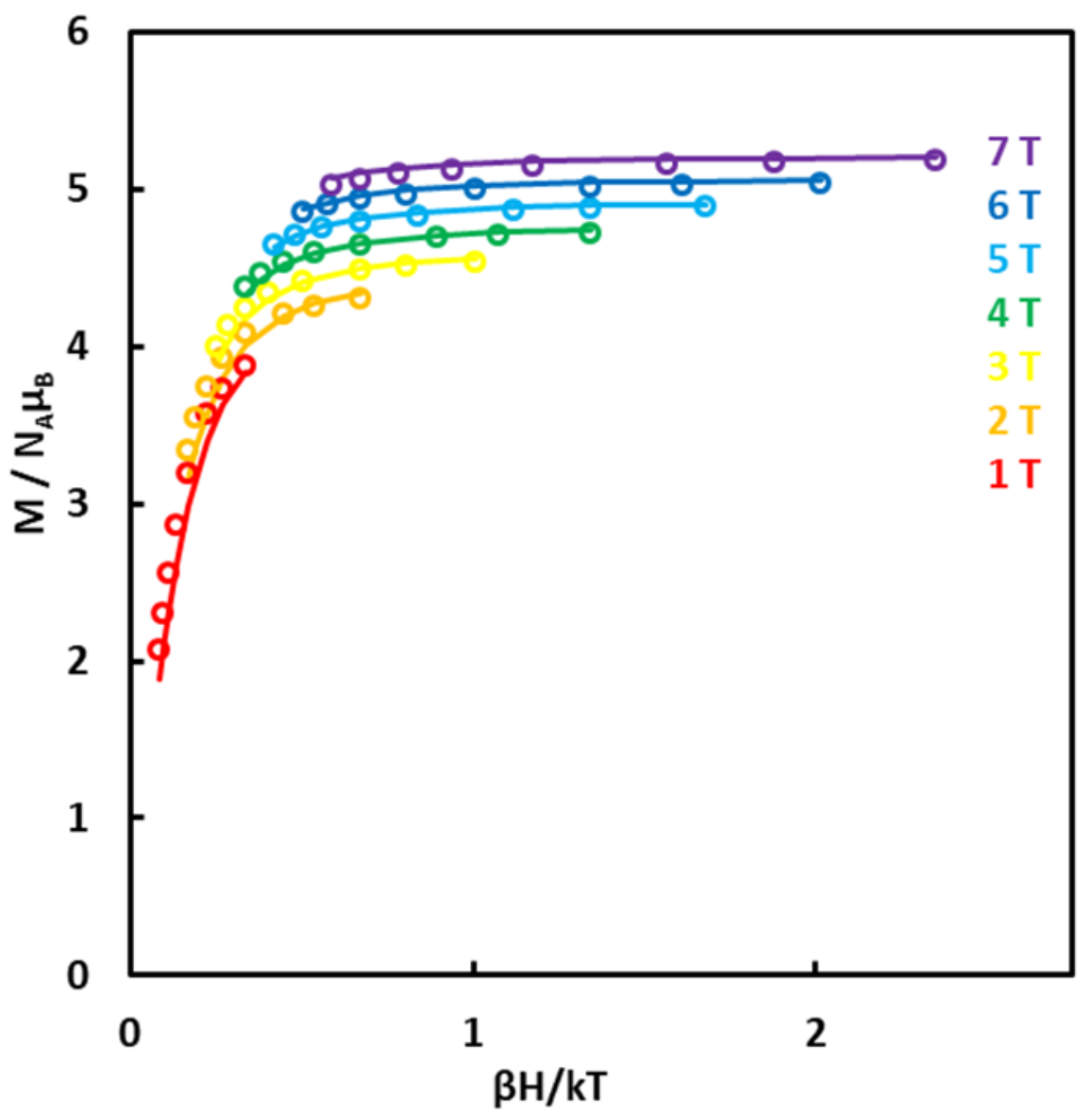

Figure S51. Reduced magnetization data for $\left[\mathrm{LFe}_{3} \mathrm{O}\left({ }^{\mathrm{pCF} 3} \mathrm{ArIm}\right)_{3} \mathrm{Fe}\right][\mathrm{OTf}]_{2}\left(\mathbf{1}^{\mathrm{CF} 3}\right)$ collected between 1.8 and $8 \mathrm{~K}$ at field between 1 and $7 \mathrm{~T}$ (colored circles). Simulation according to the system spin Hamiltonian $H=D S_{z}{ }^{2}+E\left(S_{x}{ }^{2}+S_{y}{ }^{2}\right)+g \mu_{B} \mathbf{S} \cdot \mathbf{H}$ with $\mathbf{S}=4, g=2.00, D=-4.10 \mathrm{~cm}^{-1}$, $|E / D|=0.195$. 


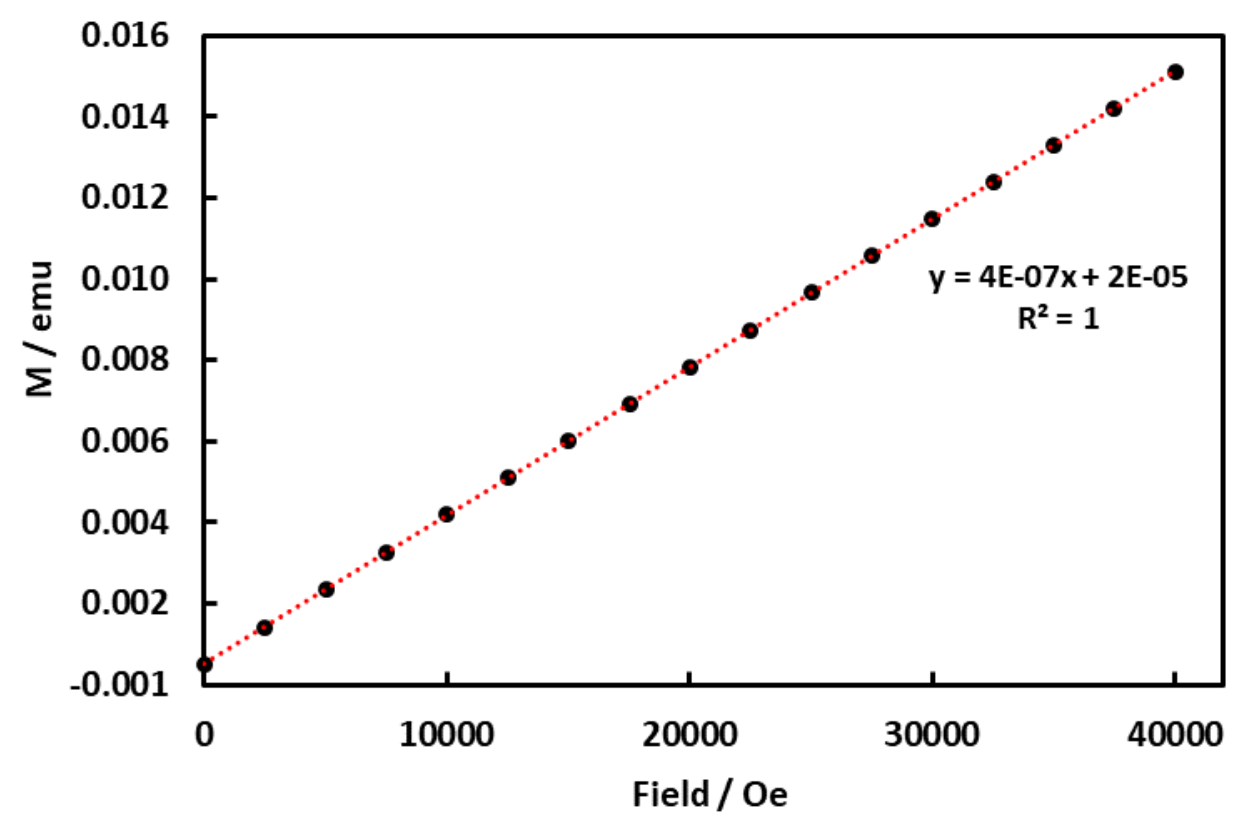

Figure S52. Magnetization data collected at $100 \mathrm{~K}$ from 0 to $4 \mathrm{~T}$ for $\left[\mathrm{LFe}_{3} \mathrm{O}\left({ }^{\mathrm{pNMe} 2} \mathrm{ArIm}\right)_{3} \mathrm{Fe}\right][\mathrm{OTf}]_{2}\left(\mathbf{1}^{\mathrm{NMe} 2}\right)$ to confirm the absence of ferromagnetic impurities.

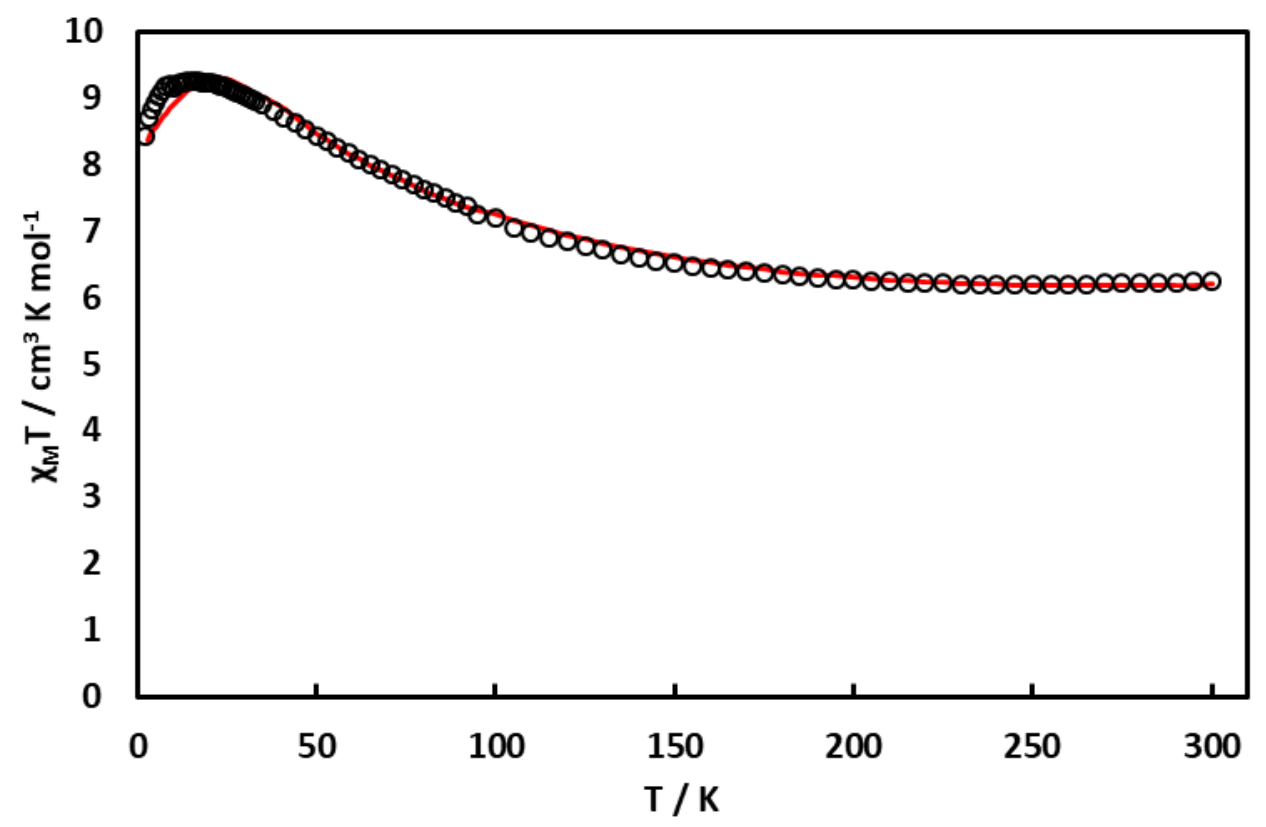

Figure S53. Direct current variable temperature magnetic susceptibility measurements for $\left[\mathrm{LFe}_{3} \mathrm{O}\left({ }^{\mathrm{pNMe} 2} \mathrm{ArIm}\right)_{3} \mathrm{Fe}\right][\mathrm{OTf}]_{2}\left(\mathbf{1}^{\mathrm{NMe} 2}\right)$ collected between 1.8 and $300 \mathrm{~K}$ with a $0.1 \mathrm{~T}$ field after diamagnetic correction (black circles). Best fit parameters including zero-field splitting effects: $S_{1}=S_{3}=2, S_{2}=S_{4}=5 / 2 ; g_{1}=g_{2}=g_{3}=g_{4}=2.00 ;\left|D_{1}\right|=\left|D_{3}\right|=5.8 \mathrm{~cm}^{-1},\left|D_{2}\right|=0 \mathrm{~cm}^{-1},\left|D_{4}\right|=0.8$ $\mathrm{cm}^{-1} ; J_{14}=J_{34}=-26.1 \mathrm{~cm}^{-1}, J_{24}=-69.4 \mathrm{~cm}^{-1}, J_{12}=J_{23}=-4.5 \mathrm{~cm}^{-1}, J_{13}=-10 \mathrm{~cm}^{-1}$. 


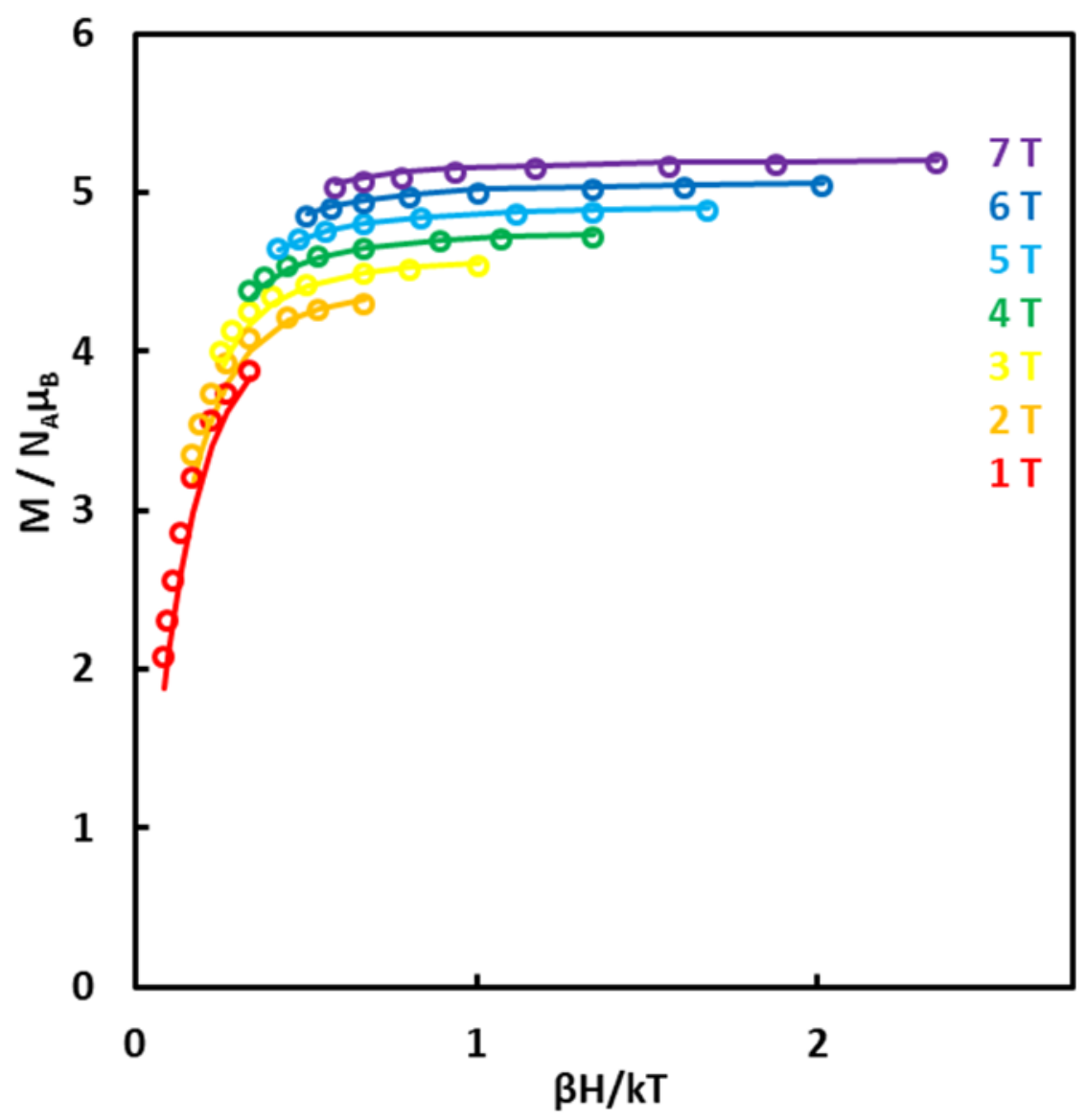

Figure S54. Reduced magnetization data for $\left[\mathrm{LFe}_{3} \mathrm{O}\left({ }^{\left(\mathrm{pNMe}^{2}\right.} \mathrm{ArIm}\right)_{3} \mathrm{Fe}\right][\mathrm{OTf}]_{2}\left(\mathbf{1}^{\mathrm{NMe} 2}\right)$ collected between 1.8 and $8 \mathrm{~K}$ at field between 1 and $7 \mathrm{~T}$ (colored circles). Simulation according to the system spin Hamiltonian $H=D S_{z}{ }^{2}+E\left(S_{x}{ }^{2}+S_{y}{ }^{2}\right)+g \mu_{B} \mathbf{S} \cdot \mathbf{H}$ with $\mathbf{S}=4, g=2.00, D=-3.176 \mathrm{~cm}^{-}$ $1,|E / D|=0.251$.

Simulation Details for $\left[\mathrm{LFe}_{3} \mathrm{O}\left({ }^{\mathrm{pCF}} \mathrm{ArIm}\right)_{3} \mathrm{Fe}\right][\mathrm{OTf}]\left(2^{\mathrm{CF} 3}\right)$ and $\left[\mathrm{LFe}_{3} \mathrm{O}(\mathrm{PhIm})_{3} \mathrm{Fe}\right]\left[\mathrm{BF}_{4}\right]\left(2^{\mathrm{H}}\right)$ : the molar susceptibilities of $2^{\mathrm{CF} 3}$ and $\mathbf{2}^{\mathrm{H}}$ decrease monotonically with temperature, reaching values of $3.16 \mathrm{~cm}^{3} \mathrm{~K} \mathrm{~mol}^{-1}$ and $1.81 \mathrm{~cm}^{3} \mathrm{~K} \mathrm{~mol}^{-1}$, respectively, at $1.8 \mathrm{~K}$. No plateau is observed in the $\chi_{\mathrm{M}} \mathrm{T}$ values down to $1.8-5 \mathrm{~K}$, suggests that neither $2^{\mathbf{C F} 3}$ nor $\mathbf{2}^{\mathbf{H}}$ possess a well-isolated spin ground state. Simulations of the experimental data reveal significantly smaller $J_{14}=J_{34}$ coupling constants for $2^{\mathrm{CF} 3}$ and $\mathbf{2}^{\mathrm{H}}\left(-2.1 \mathrm{~cm}^{-1}\right.$ and $-5 \mathrm{~cm}^{-1}$, respectively) compared to $\mathbf{1}^{\mathrm{NMe} 2}\left(-29 \mathrm{~cm}^{-1}\right)$. While the intracore exchange coupling remains weak $\left(J_{12}=J_{23}=-2.3 \mathrm{~cm}^{-1}, J_{13}=-0.6 \mathrm{~cm}^{-1}\right.$ for $2^{\text {CF3 }} ; J_{12}=J_{23}$ $=-4.8 \mathrm{~cm}^{-1}, J_{13}=-1.3 \mathrm{~cm}^{-1}$ for $2^{\mathrm{H}}$ ), the smaller values of $J_{14}=J_{34}$ are no longer large enough to spin frustrate the triiron core. As a result, the calculated energy level diagrams for $\mathbf{2}^{\mathbf{C F 3}}$ and $\mathbf{2}^{\mathbf{H}}$ indicate multiple low lying excited states with energies as low as c.a. $0.3 \mathrm{~cm}^{-1}$ and $0.6 \mathrm{~cm}^{-1}$, respectively (equivalent temperatures $0.4 \mathrm{~K}$ and $0.9 \mathrm{~K}$ ). This is in stark contrast to $2^{\mathbf{N M e} 2}$ for which the first excited sextet state is predicted at c.a. $120 \mathrm{~cm}^{-1}$ (equivalent temperature $173 \mathrm{~K}$ ).

The significantly smaller magnetization saturation values of $2^{\mathbf{C F} 3}$ and $\mathbf{2}^{\mathbf{H}}\left(3.5 \mu_{\mathrm{B}}\right.$ and $4.1 \mu_{\mathrm{B}}$, respectively) at $1.8 \mathrm{~K}$ and $7 \mathrm{~T}$ suggest a spin ground state distinct from that of $\mathbf{2}^{\mathbf{N M e} 2}$. However, attempts to simulate the experimental data according to the Hamiltonian $H=D S_{z}{ }^{2}+E\left(S_{x}{ }^{2}+S_{y}{ }^{2}\right)$ 
$+g \mu_{B} \mathbf{S} \cdot \mathbf{H}$ did not afford reasonable simulations assuming $S=3 / 2,5 / 2$, or 7/2 (Supplementary Figs. 58-60 and 64-65). Application of this spin Hamiltonian to multimetallic assemblies is predicated on the presence of a well-isolated, pure spin ground state and, thus, strong exchange coupling. ${ }^{38}$ The absence of limiting values of $\chi_{\mathrm{M}} \mathrm{T}$ for $2^{\mathbf{C F} 3}$ and $\mathbf{2}^{\mathbf{H}}$ suggests the presence of low lying excited states which are accessible even at these low temperatures, consistent with simulations. Moreover, strong magnetic anisotropy, indicated by the non-superimposable isofield curves, mixes low-lying levels of different spin, such that $\mathbf{2}^{\mathbf{C F} 3}$ and $\mathbf{2}^{\mathbf{H}}$ no longer possess pure spin ground states. ${ }^{39-42}$ The absence of significant zero-field splitting in $2^{\mathbf{N M e} 2}$, which differs from $2^{\mathbf{C F 3}}$ and $\mathbf{2}^{\mathbf{H}}$ primarily in its electronic distribution, suggests that this magnetic anisotropy may be related to the oxidation state of the apical metal site. Indeed, a series of mononuclear, trigonal pyramidal $\mathrm{Fe}^{\mathrm{II}}$ complexes supported by a tris(pyrrolide)amine ligand have been reported with axial zero-field splitting parameters $|D|$ as large as $48 \mathrm{~cm}^{-1} \cdot{ }^{43}$ While the degeneracy of the (xz,yz) orbital set is lifted by a Jahn-Teller distortion of the Fe4- $\mathrm{C}_{\mathrm{Im}}$ bond lengths (Table 1), thereby quenching the orbital moment, the presence of low-lying orbital excited states results in significant single-ion zero-field splitting at Fe4, ${ }^{44}$ which contributes to the strong magnetic anisotropy of $\mathbf{2}^{\mathbf{C F} 3}$ and $\mathbf{2}^{\mathbf{H}}$.

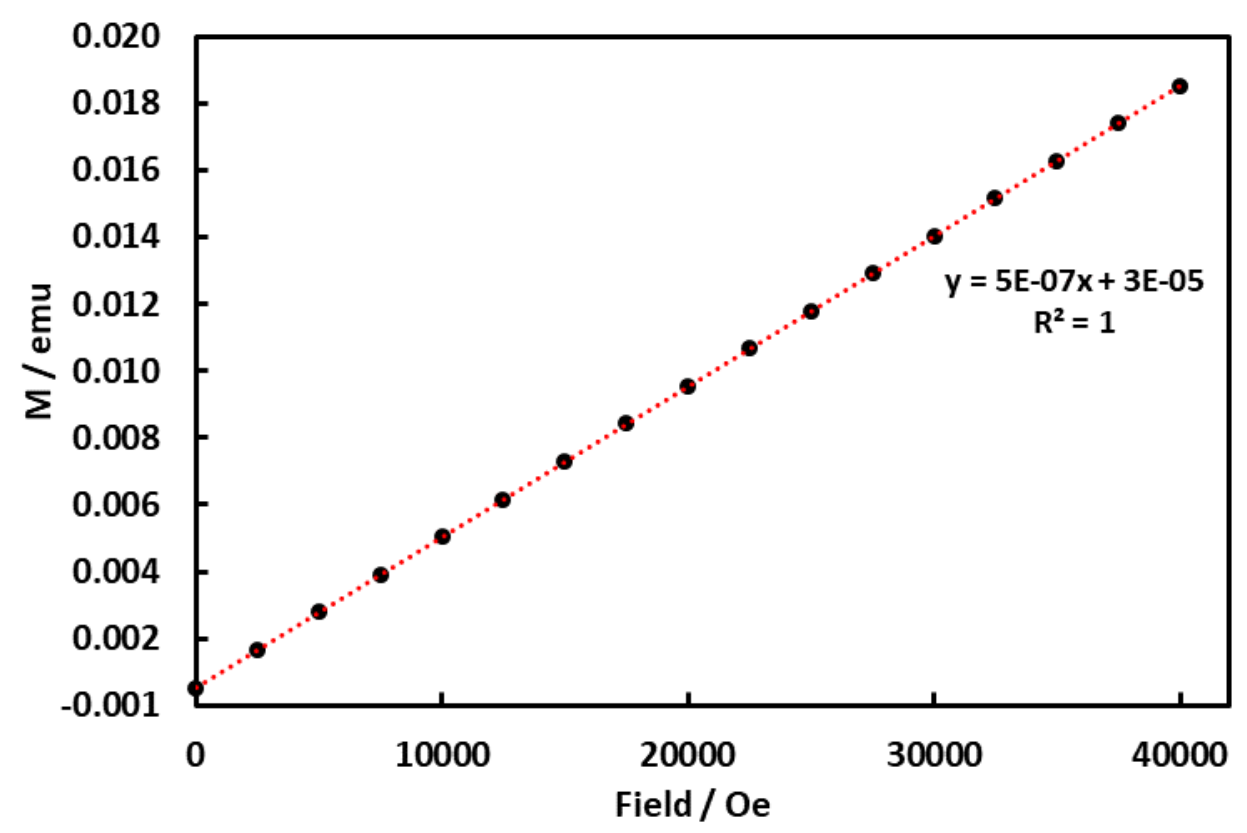

Figure S55. Magnetization data collected at $100 \mathrm{~K}$ from 0 to $4 \mathrm{~T}$ for $\left[\mathrm{LFe}_{3} \mathrm{O}\left({ }^{\mathrm{pCF} 3} \mathrm{ArIm}\right)_{3} \mathrm{Fe}\right][\mathrm{OTf}]$ $\left(2^{\mathbf{C F 3}}\right)$ to confirm the absence of ferromagnetic impurities. 


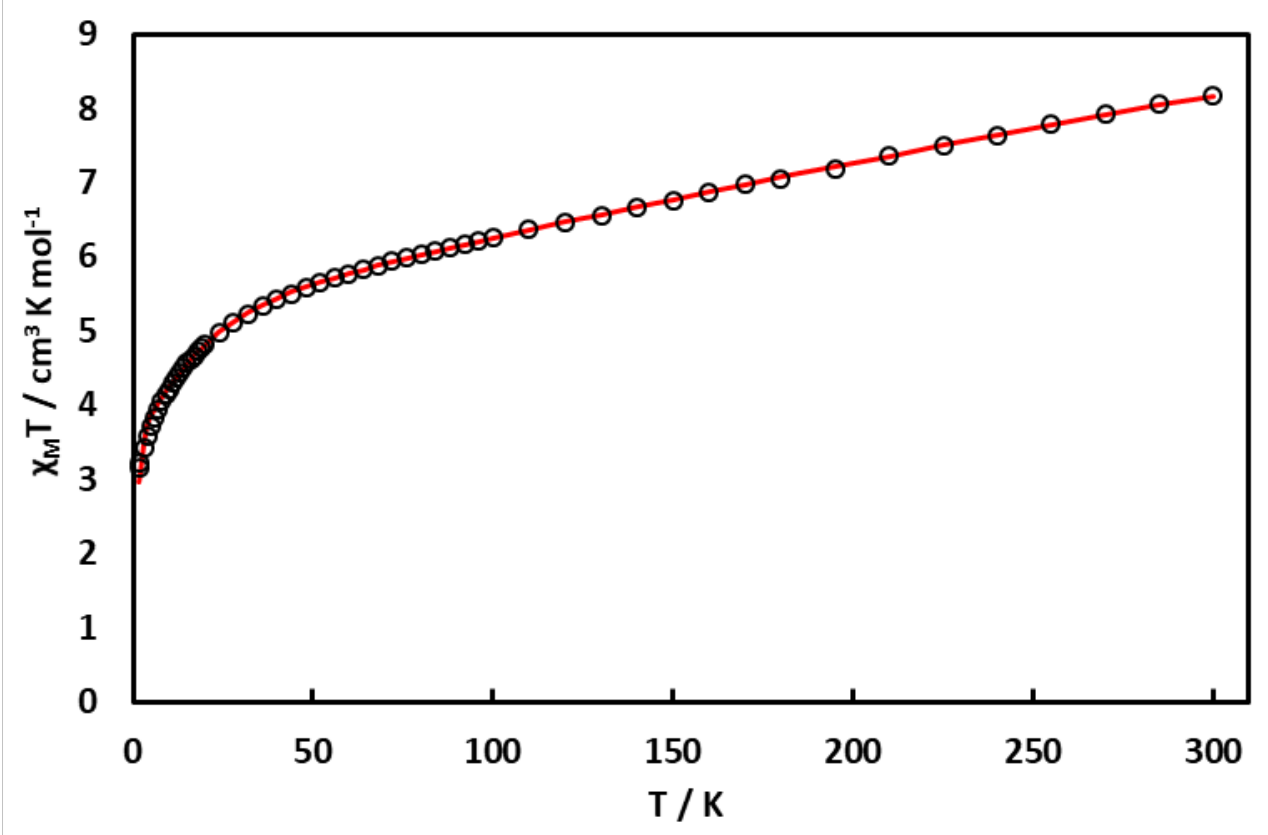

Figure S56. Direct current variable temperature magnetic susceptibility measurements for $\left[\mathrm{LFe}_{3} \mathrm{O}\left({ }^{\mathrm{pCF3}} \mathrm{ArIm}\right)_{3} \mathrm{Fe}\right][\mathrm{OTf}]\left(2^{\mathrm{CF} 3}\right)$ collected between 1.8 and $300 \mathrm{~K}$ with a $0.1 \mathrm{~T}$ field after diamagnetic correction (black circles). Full Fit parameters: $S_{1}=S_{3}=S_{4}=2, S_{2}=5 / 2 ; g_{1}=g_{2}=g_{3}$ $=g_{4}=2.00 ; J_{14}=J_{34}=-2.1 \mathrm{~cm}^{-1}, J_{24}=-37 \mathrm{~cm}^{-1}, J_{12}=J_{23}=-2.3 \mathrm{~cm}^{-1}, J_{13}=-0.6 \mathrm{~cm}^{-1}$.

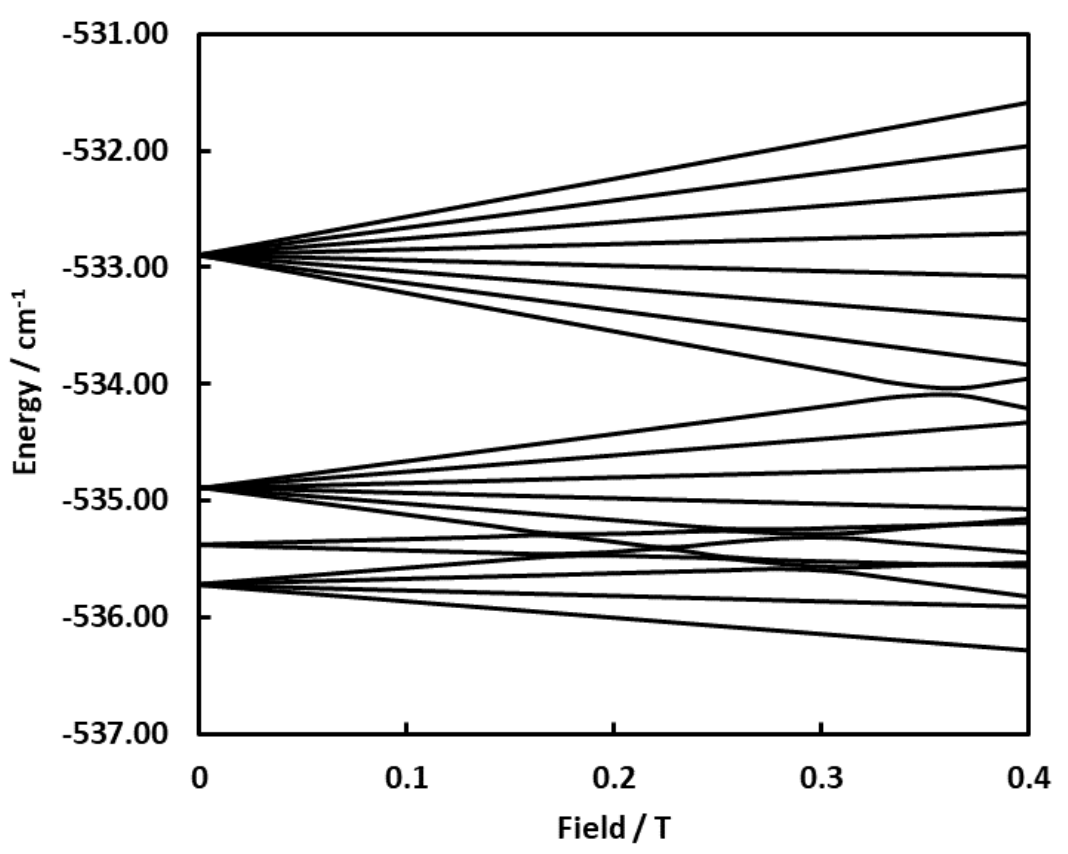

Figure S57. Calculated Zeeman diagram for $\left[\mathrm{LFe}_{3} \mathrm{O}\left({ }^{\mathrm{pCF} 3} \mathrm{ArIm}\right)_{3} \mathrm{Fe}\right][\mathrm{OTf}]\left(\mathbf{2}^{\mathrm{CF} 3}\right)$ using parameters derived from simulations of magnetic susceptibility data. The calculated energy level diagram indicates excited state doublet, sextet and octet separated by only c.a. $0.3 \mathrm{~cm}^{-1}, 0.8 \mathrm{~cm}^{-1}$ and $2.8 \mathrm{~cm}^{-1}$ from the quartet ground state. 


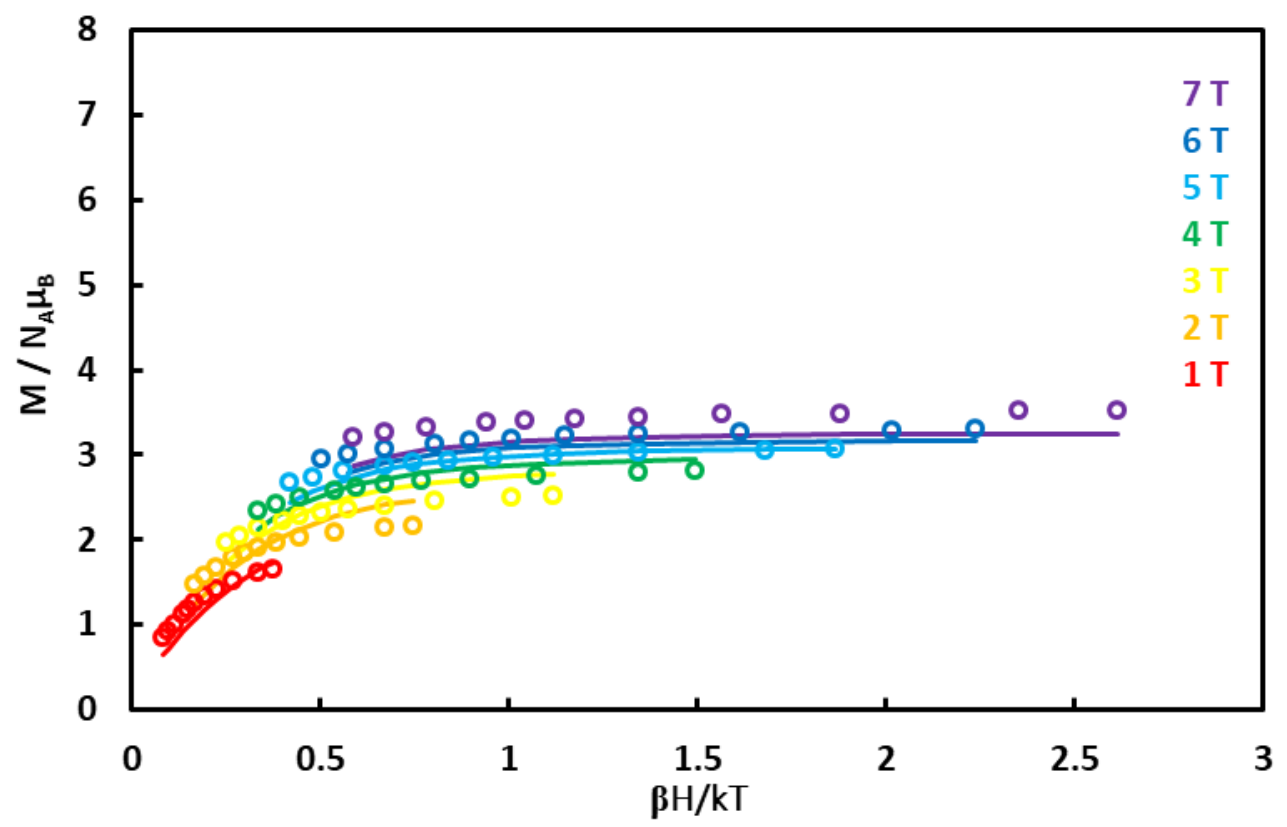

Figure S58. Reduced magnetization data for $\left[\mathrm{LFe}_{3} \mathrm{O}\left({ }^{\mathrm{pCF}} \mathrm{ArIm}\right)_{3} \mathrm{Fe}\right][\mathrm{OTf}]_{2}\left(2^{\mathbf{C F} 3}\right)$ collected between 1.8 and $8 \mathrm{~K}$ at field between 1 and $7 \mathrm{~T}$ (colored circles). Attempted simulation according to the system spin Hamiltonian $H=D S_{z}^{2}+E\left(S_{x}^{2}+S_{y}{ }^{2}\right)+g \mu_{B} \mathbf{S} \cdot \mathbf{H}$ with $S=7 / 2, g=$ $1.33, D=5.7 \mathrm{~cm}^{-1},|E / D|=0$.

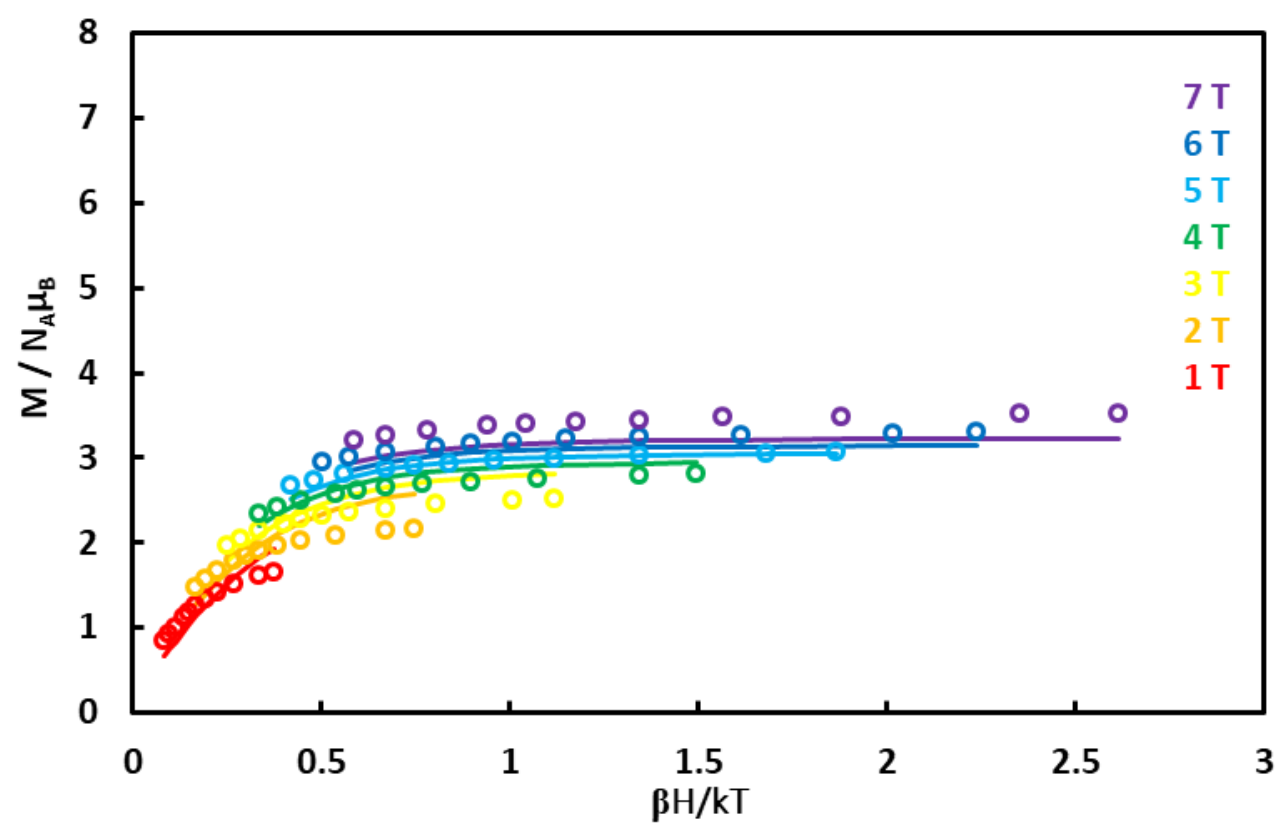

Figure S59. Reduced magnetization data for $\left[\mathrm{LFe}_{3} \mathrm{O}\left({ }^{\mathrm{pCF} 3} \mathrm{ArIm}\right)_{3} \mathrm{Fe}\right][\mathrm{OTf}]_{2}\left(\mathbf{2}^{\mathrm{CF} 3}\right)$ collected between 1.8 and $8 \mathrm{~K}$ at field between 1 and $7 \mathrm{~T}$ (colored circles). Attempted simulation according to the system spin Hamiltonian $H=D S_{z}{ }^{2}+E\left(S_{x}{ }^{2}+S_{y}{ }^{2}\right)+g \mu_{B} \mathbf{S} \cdot \mathbf{H}$ with $S=5 / 2, g=$ $2.00, D=14.8 \mathrm{~cm}^{-1},|E / D|=0$. 


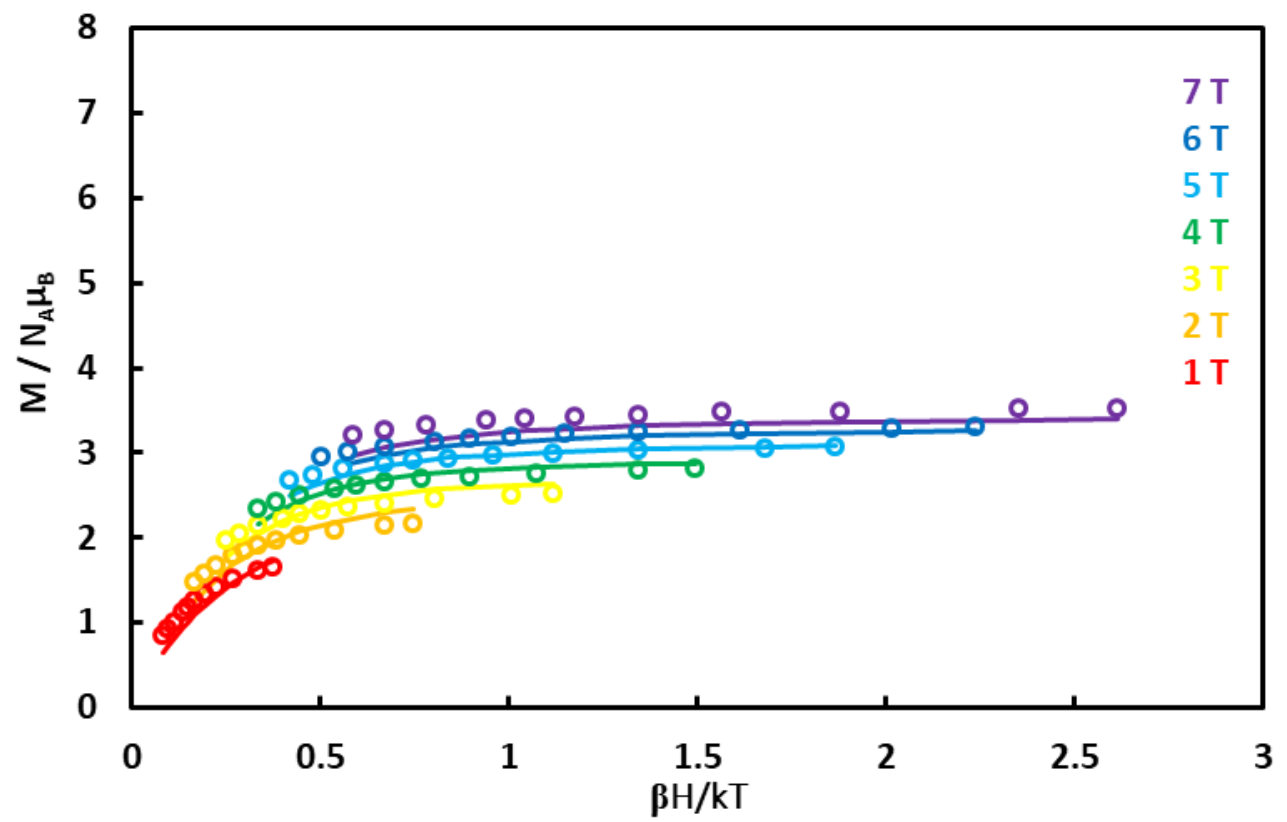

Figure S60. Reduced magnetization data for $\left[\mathrm{LFe}_{3} \mathrm{O}\left({ }^{\mathrm{pCF} 3} \mathrm{ArIm}\right)_{3} \mathrm{Fe}\right][\mathrm{OTf}]_{2}\left(2^{\mathrm{CF} 3}\right)$ collected between 1.8 and $8 \mathrm{~K}$ at field between 1 and $7 \mathrm{~T}$ (colored circles). Attempted simulation according to the system spin Hamiltonian $H=D S_{z}^{2}+E\left(S_{x}{ }^{2}+S_{y}{ }^{2}\right)+g \mu_{B} \mathbf{S} \cdot \mathbf{H}$ with $S=3 / 2, g=$ 2.67, $D=-6.4 \mathrm{~cm}^{-1},|E / D|=0$.

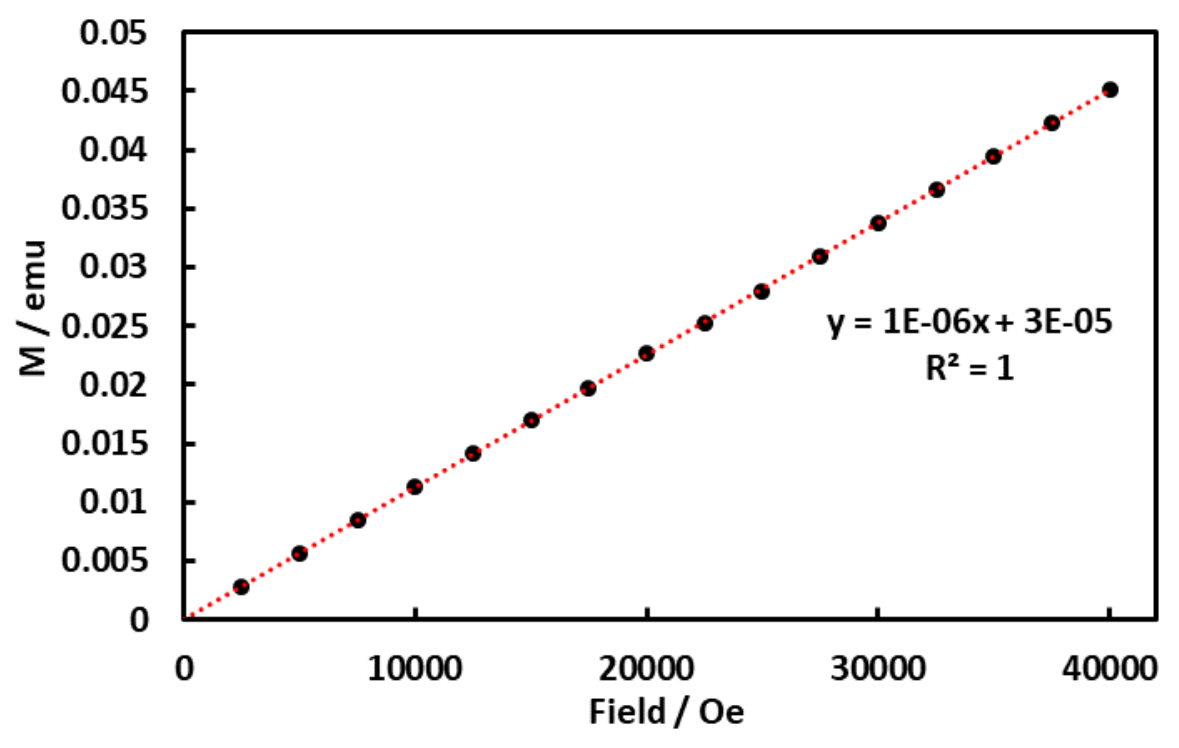

Figure S61. Magnetization data collected at $100 \mathrm{~K}$ from 0 to $4 \mathrm{~T}$ for $\left[\mathrm{LFe}_{3} \mathrm{O}(\mathrm{PhIm})_{3} \mathrm{Fe}\right][\mathrm{OTf}]$ $\left(2^{\mathrm{H}}\right)$ to confirm the absence of ferromagnetic impurities. 


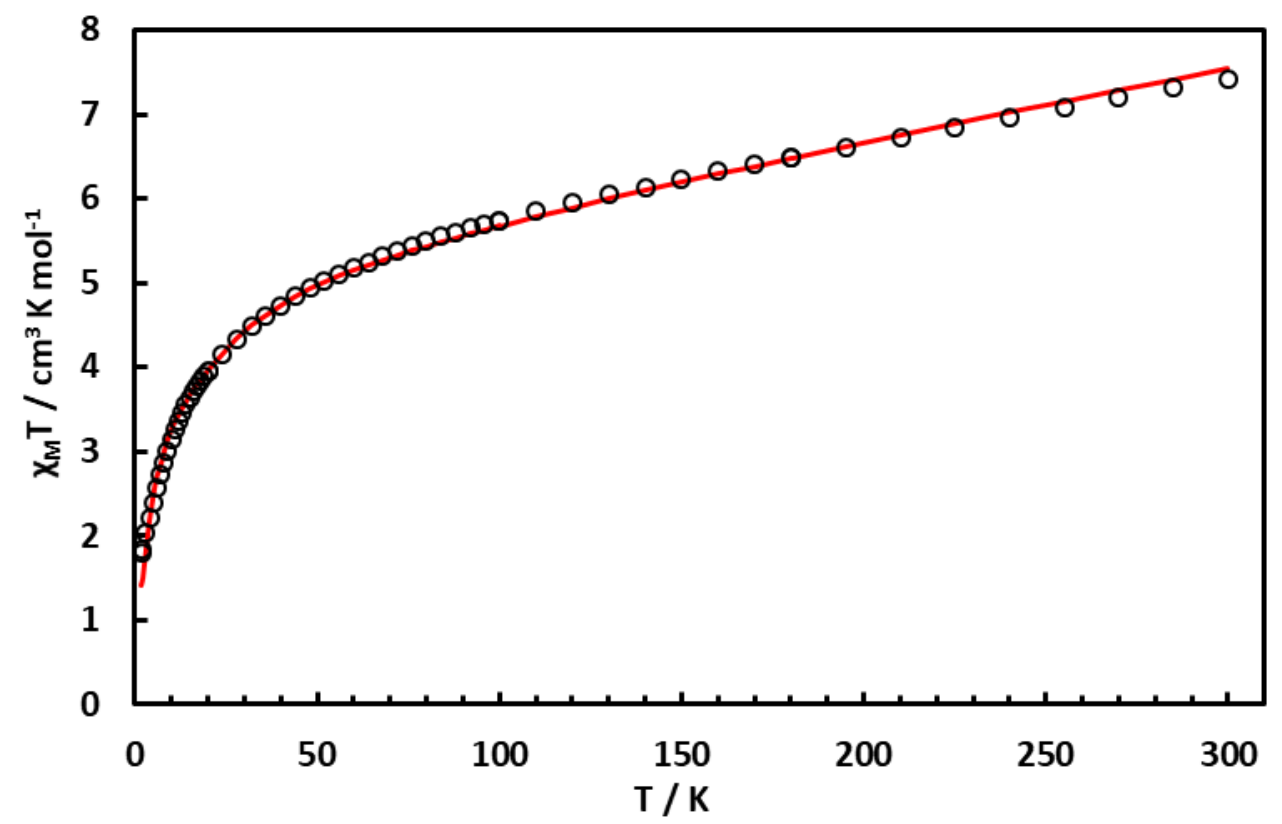

Figure S62. Direct current variable temperature magnetic susceptibility measurements for $\left[\mathrm{LFe}_{3} \mathrm{O}(\mathrm{PhIm})_{3} \mathrm{Fe}\right]\left[\mathrm{BF}_{4}\right]\left(\mathbf{2}^{\mathrm{H}}\right)$ collected between 1.8 and $300 \mathrm{~K}$ with a $0.1 \mathrm{~T}$ field after diamagnetic correction (black circles). Full Fit parameters: $S_{1}=S_{3}=S_{4}=2, S_{2}=5 / 2 ; g_{1}=g_{2}=g_{3}$ $=g_{4}=2.00 ; J_{14}=J_{34}=-5.0 \mathrm{~cm}^{-1}, J_{24}=-40 \mathrm{~cm}^{-1}, J_{12}=J_{23}=-4.8 \mathrm{~cm}^{-1}, J_{13}=-1.3 \mathrm{~cm}^{-1}$.

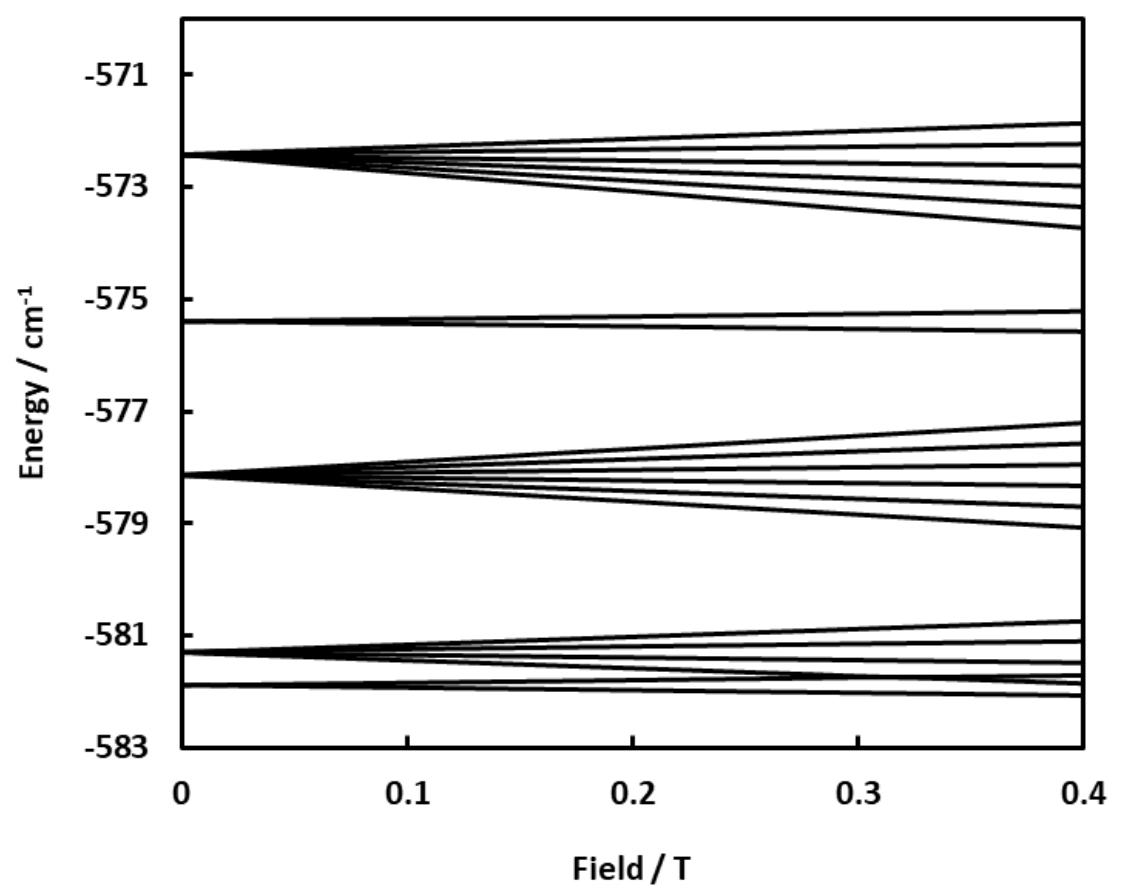

Figure S63. Calculated Zeeman diagram for $\left[\mathrm{LFe}{ }_{3} \mathrm{O}(\mathrm{PhIm})_{3} \mathrm{Fe}\right][\mathrm{OTf}]\left(\mathbf{2}^{\mathbf{H}}\right)$ using parameters derived from simulations of magnetic susceptibility data. The calculated energy level diagram indicates excited state quartet, sextet, doublet and sextet separated by only c.a. $0.6 \mathrm{~cm}^{-1}, 3.7 \mathrm{~cm}^{-1}$, $6.5 \mathrm{~cm}^{-1}$ and $9.5 \mathrm{~cm}^{-1}$ from the doublet ground state. 


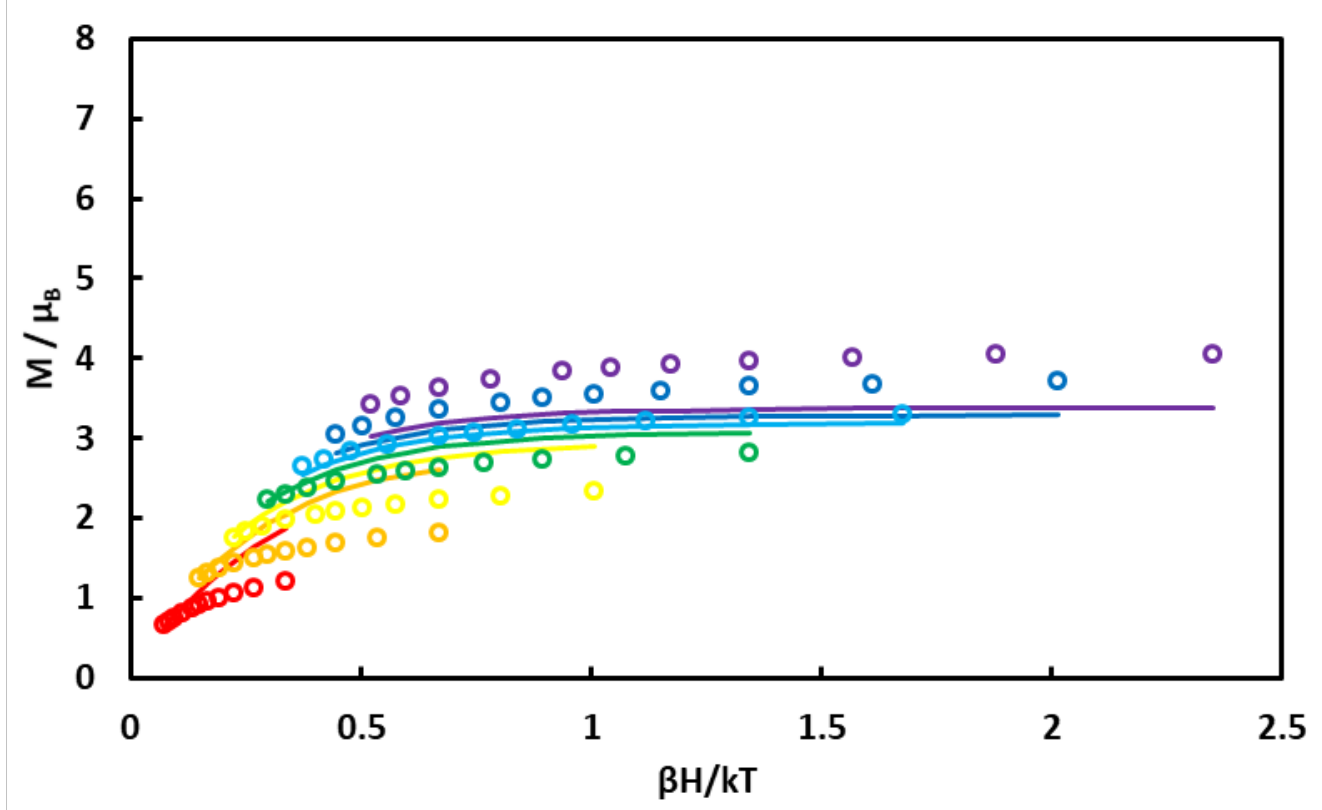

Figure S64. Reduced magnetization data for $\left[\mathrm{LFe}{ }_{3} \mathrm{O}(\mathrm{PhIm})_{3} \mathrm{Fe}\right][\mathrm{OTf}]_{2}\left(\mathbf{2}^{\mathbf{H}}\right)$ collected between 2 and $9 \mathrm{~K}$ at field between 1 and $7 \mathrm{~T}$ (colored circles). Attempted simulation according to the system spin Hamiltonian $H=D S_{z}{ }^{2}+E\left(S_{x}{ }^{2}+S_{y}{ }^{2}\right)+g \mu_{B} \mathbf{S} \cdot \mathbf{H}$ with $S=5 / 2, g=2.00, D=11.1 \mathrm{~cm}^{-}$ ${ }^{1},|E / D|=0$.

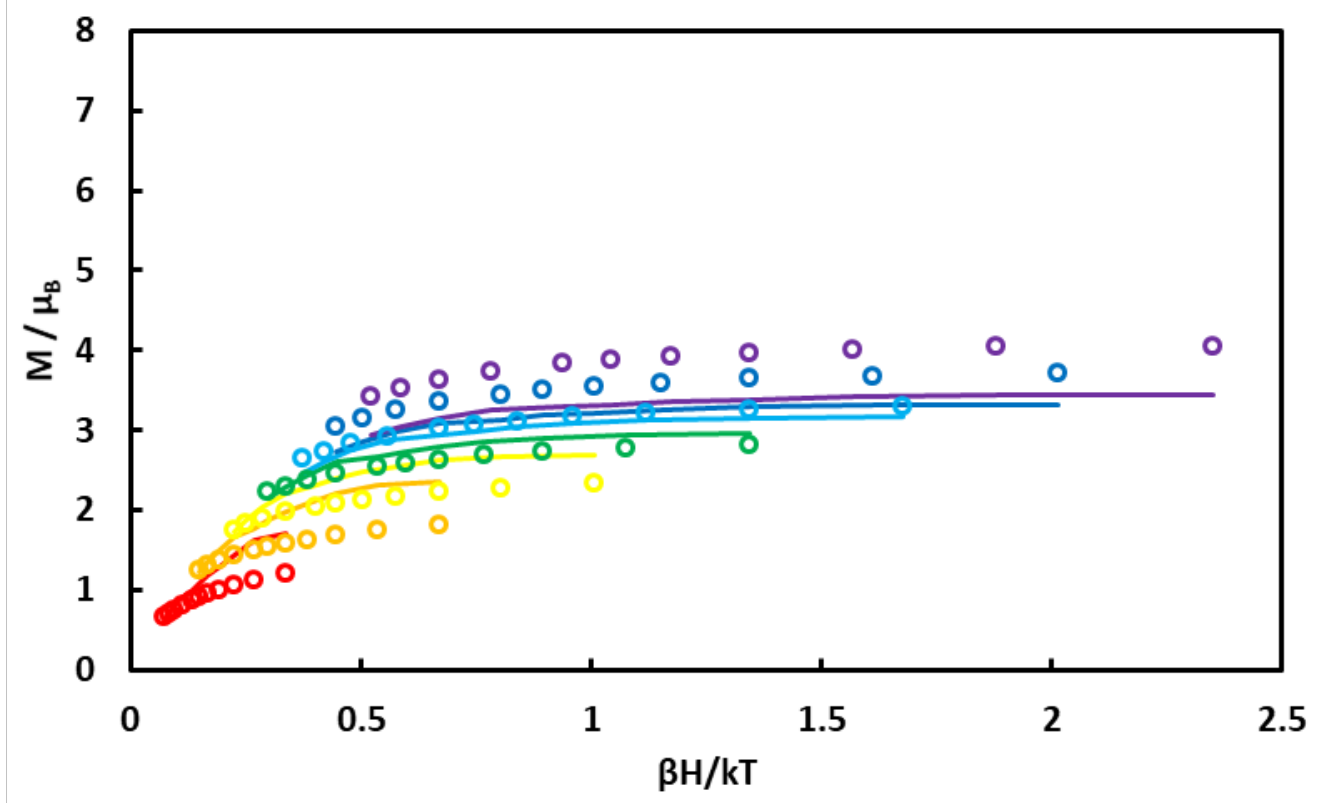

Figure S65. Reduced magnetization data for $\left[\mathrm{LFe} \mathrm{O}_{3} \mathrm{O}(\mathrm{PhIm})_{3} \mathrm{Fe}\right][\mathrm{OTf}]_{2}\left(2^{\mathbf{H}}\right)$ collected between 2 and $9 \mathrm{~K}$ at field between 1 and $7 \mathrm{~T}$ (colored circles). Attempted simulation according to the system spin Hamiltonian $H=D S_{z}{ }^{2}+E\left(S_{x}{ }^{2}+S_{y}{ }^{2}\right)+g \mu_{B} \mathbf{S} \cdot \mathbf{H}$ with $S=3 / 2, g=2.57, D=-4.9 \mathrm{~cm}^{-}$ ${ }^{1},|E / D|=0$. 
Simulation Details for $\left[\mathrm{LFe}_{3} \mathrm{O}\left(\mathrm{P}^{\mathrm{NMe}} \mathbf{A r I m}\right)_{3} \mathbf{F e}\right][\mathrm{OTf}]\left(2^{\mathrm{NMe}}\right)$ : The value of $\chi_{\mathrm{MT}} \mathrm{T}$ for $2^{\mathrm{NMe} 2}$ at 300 $\mathrm{K}\left(6.35 \mathrm{~cm}^{3} \mathrm{~K} \mathrm{~mol}^{-1}\right)$ deviates significantly from the spin-only value $\left(13.38 \mathrm{~cm}^{3} \mathrm{~K} \mathrm{~mol}^{-1}\right)$ anticipated for uncoupled $\mathrm{Fe}^{\mathrm{II}}(S=2)$ and $\mathrm{Fe}^{\mathrm{III}}(S=5 / 2)$ centers, indicating the presence of antiferromagnetic coupling. However, $\chi_{\mathrm{M}} \mathrm{T}$ increases gradually as the temperature is lowered, eventually reaching a plateau $\left(7.87 \mathrm{~cm}^{3} \mathrm{~K} \mathrm{~mol}^{-1}\right)$ between $10-40 \mathrm{~K}$ corresponding to the expected spin-only value for an isolated $S=7 / 2$ center $(g=2.00)$. The near-ideal Curie behavior observed between $10-40 \mathrm{~K}$ suggests that excited states with $S \neq 7 / 2$ are not thermally accessible. An exchange coupling model $\left(J_{14}=J_{34} ; J_{12}=J_{23}\right.$, numerical subscripts chosen to be consistent with atom labels in the crystal structures) based on the pseudo- $\mathrm{C}_{\mathrm{s}}$ symmetry of the $\left[\mathrm{Fe}_{3}\left(\mu_{4}-\mathrm{O}\right) \mathrm{Fe}\right]$ core was employed to simulate the experimental data according to the spin Hamiltonian $H=-2 J_{i j}\left(S_{i} \cdot S_{j}\right)$. The effective exchange coupling constants obtained from these simulations $\left(J_{14}=J_{34}=-29 \mathrm{~cm}^{-1}\right.$, $J_{24}=-40 \mathrm{~cm}^{-1}, J_{12}=J_{23}=-3.4 \mathrm{~cm}^{-1}, J_{13}=-0.8 \mathrm{~cm}^{-1}$ ) reveal that the $S=7 / 2$ ground state originates from spin frustration of the triiron core due to strong antiferromagnetic interactions of $\mathrm{Fe} 1 / \mathrm{Fe} 2 / \mathrm{Fe} 3$ with the apical $\mathrm{Fe}^{\mathrm{III}}$ center. The larger value of $J_{24}$ (compared to $J_{14}=J_{34}$ ) is consistent with the shorter Fe2-O1 distance observed in the solid state structure. Consistent with the $S=7 / 2$ ground state inferred from magnetic susceptibility measurements, magnetization saturation for $2^{\text {NMe2 }}$ occurs at $6.6 \mu_{\mathrm{B}}$ at $1.8 \mathrm{~K}$ and $7 \mathrm{~T}$, near the expected $\mathrm{M}=g S$ limit for $g=2.00$. Simulations according to the system spin Hamiltonian $H=D S_{z}{ }^{2}+E\left(S_{x}{ }^{2}+S_{y}{ }^{2}\right)+g \mu_{B} \mathbf{S} \cdot \mathbf{H}$ best reproduce the experimental data assuming $S=7 / 2$ with $g=1.92, D=-0.21 \mathrm{~cm}^{-1}$, and $|E / D|=0$, though fits with $g=2.00, D$ $=+0.65$ are also reasonable. The small axial magnetic anisotropy $\left(|D|<1 \mathrm{~cm}^{-1}\right)$ inferred from these simulations is consistent with the observation of nearly superimposable isofield curves.

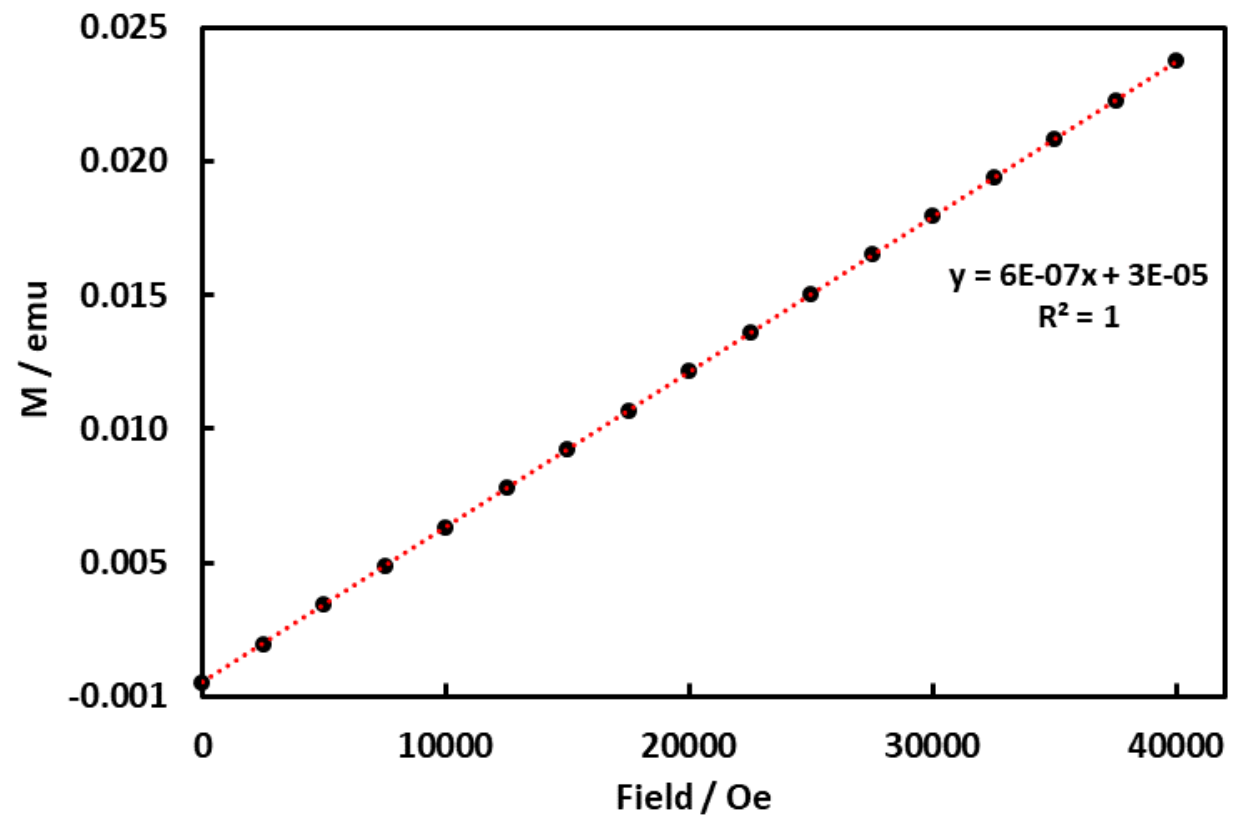

Figure S66. Magnetization data collected at $100 \mathrm{~K}$ from 0 to $4 \mathrm{~T}$ for $\left[\mathrm{LFe}_{3} \mathrm{O}\left({ }^{\mathrm{pNMe} 2} \mathrm{ArIm}\right)_{3} \mathrm{Fe}\right][\mathrm{OTf}]\left(2^{\mathrm{NMe}}\right)$ to confirm the absence of ferromagnetic impurities. 


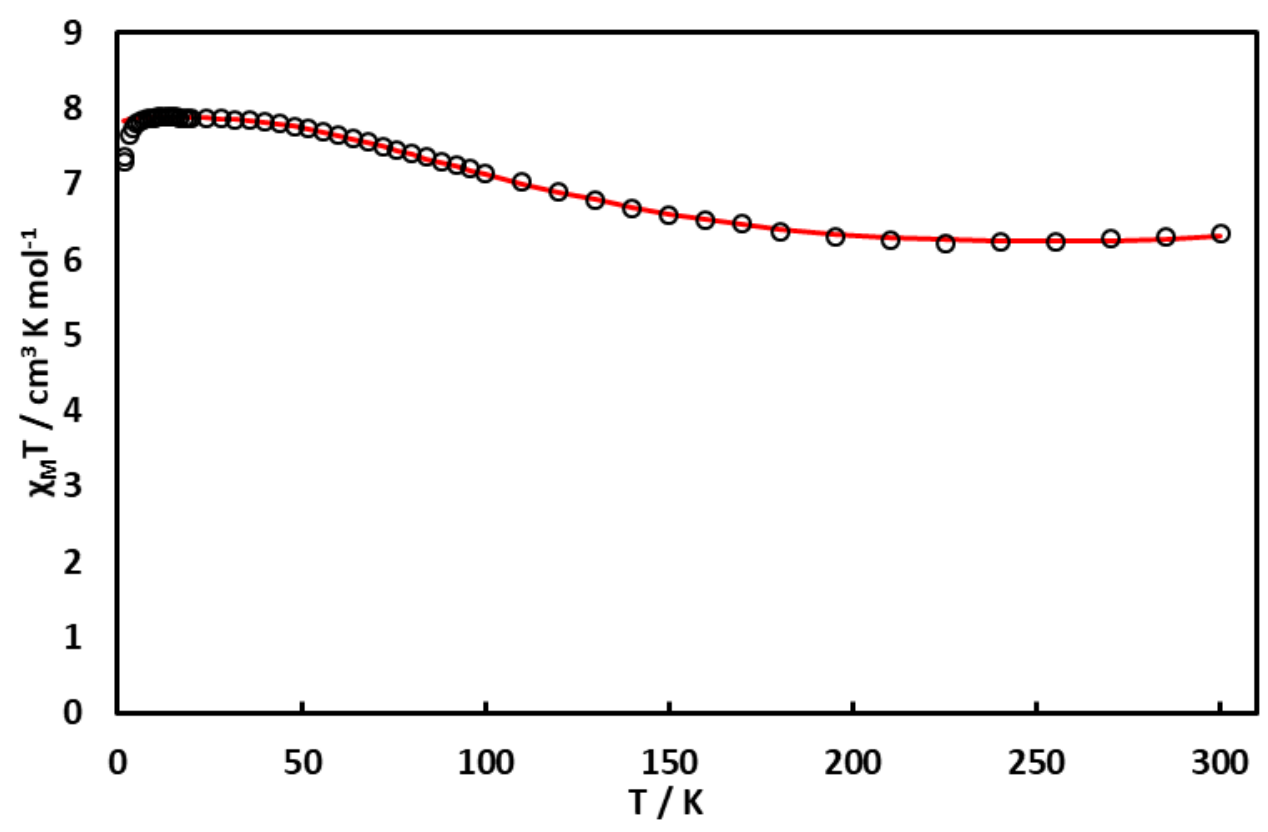

Figure S67. Direct current variable temperature magnetic susceptibility measurements for $\left[\mathrm{LFe}_{3} \mathrm{O}\left({ }^{\mathrm{pNMe} 2} \mathrm{ArIm}\right)_{3} \mathrm{Fe}\right][\mathrm{OTf}]\left(2^{\mathrm{NMe} 2}\right)$ collected between 1.8 and $300 \mathrm{~K}$ with a $0.1 \mathrm{~T}$ field after diamagnetic correction (black circles). Best fit parameters: $S_{1}=S_{2}=S_{3}=2, S_{4}=5 / 2 ; g_{1}=g_{2}=g_{3}$ $=g_{4}=2.00 ; J_{14}=J_{34}=-29 \mathrm{~cm}^{-1}, J_{24}=-40 \mathrm{~cm}^{-1}, J_{12}=J_{23}=-3.4 \mathrm{~cm}^{-1}, J_{13}=-0.8 \mathrm{~cm}^{-1}$.

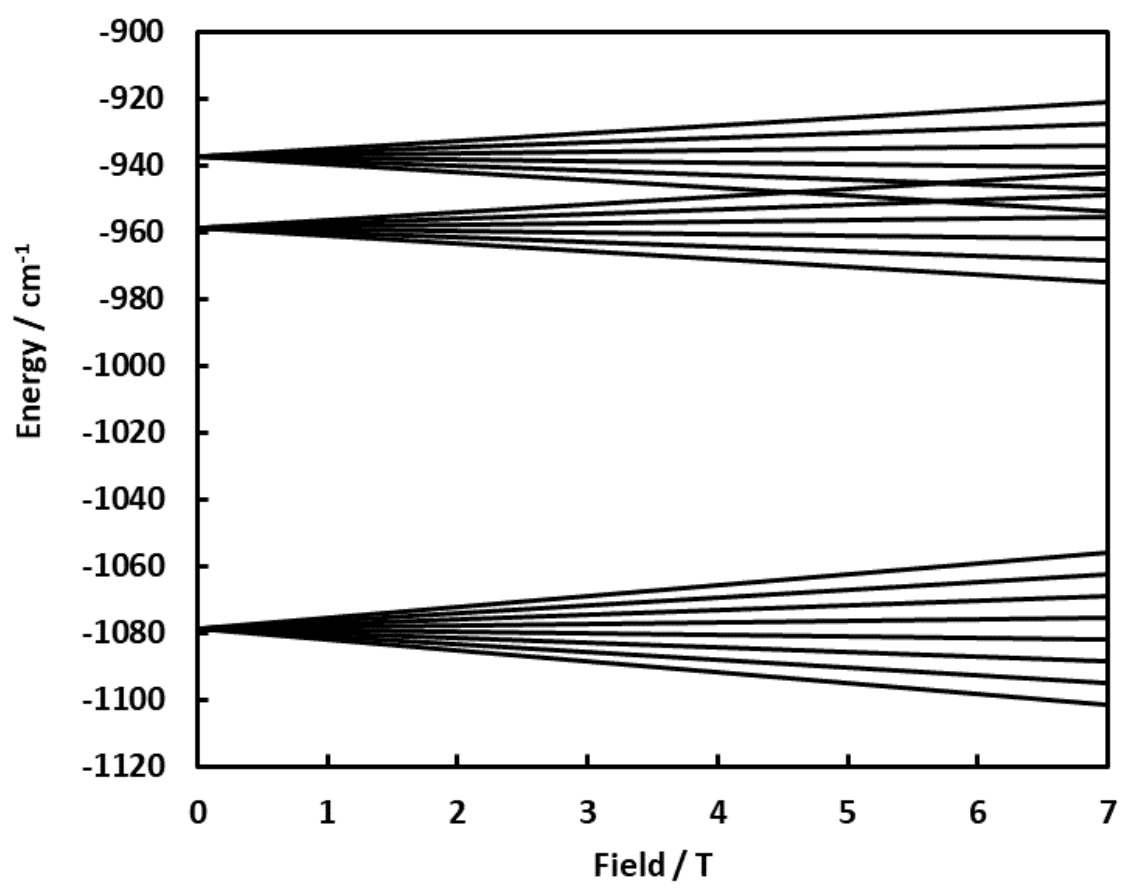

Figure S68. Calculated Zeeman diagram for $\left[\mathrm{LFe}_{3} \mathrm{O}\left(\mathrm{PNMe}^{\mathrm{NM}} \mathrm{ArIm}\right)_{3} \mathrm{Fe}\right][\mathrm{OTf}]\left(\mathbf{2}^{\mathrm{NMe} 2}\right)$ using parameters derived from simulations of magnetic susceptibility data. The calculated energy level diagram indicates a sextet excited state at c.a. $120 \mathrm{~cm}^{-1}$ (equivalent temperature $173 \mathrm{~K}$ ) higher in energy than the $S=7 / 2$ ground state. 


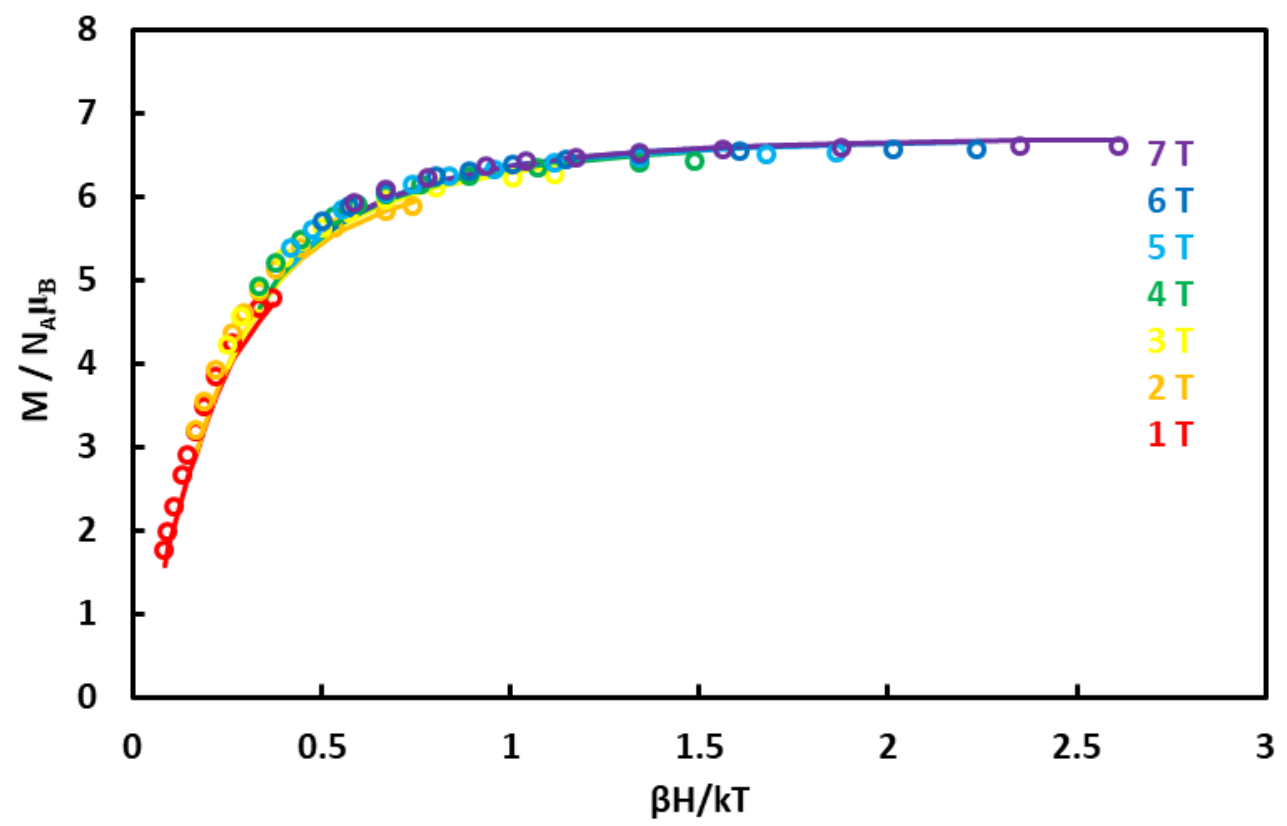

Figure S69. Reduced magnetization data for $\left[\mathrm{LFe}_{3} \mathrm{O}\left({ }^{\mathrm{pNMe} 2} \mathrm{ArIm}\right){ }_{3} \mathrm{Fe}\right][\mathrm{OTf}]\left(2^{\mathrm{NMe}}\right)$ collected between 1.8 and $8 \mathrm{~K}$ at field between 1 and $7 \mathrm{~T}$ (colored circles). Simulation according to the system spin Hamiltonian $H=D S_{z}{ }^{2}+E\left(S_{x}{ }^{2}+S_{y}{ }^{2}\right)+g \mu_{B} \mathbf{S} \cdot \mathbf{H}$ with $S=7 / 2, g=1.92, D=-0.21$ $\mathrm{cm}^{-1},|E / D|=0$.

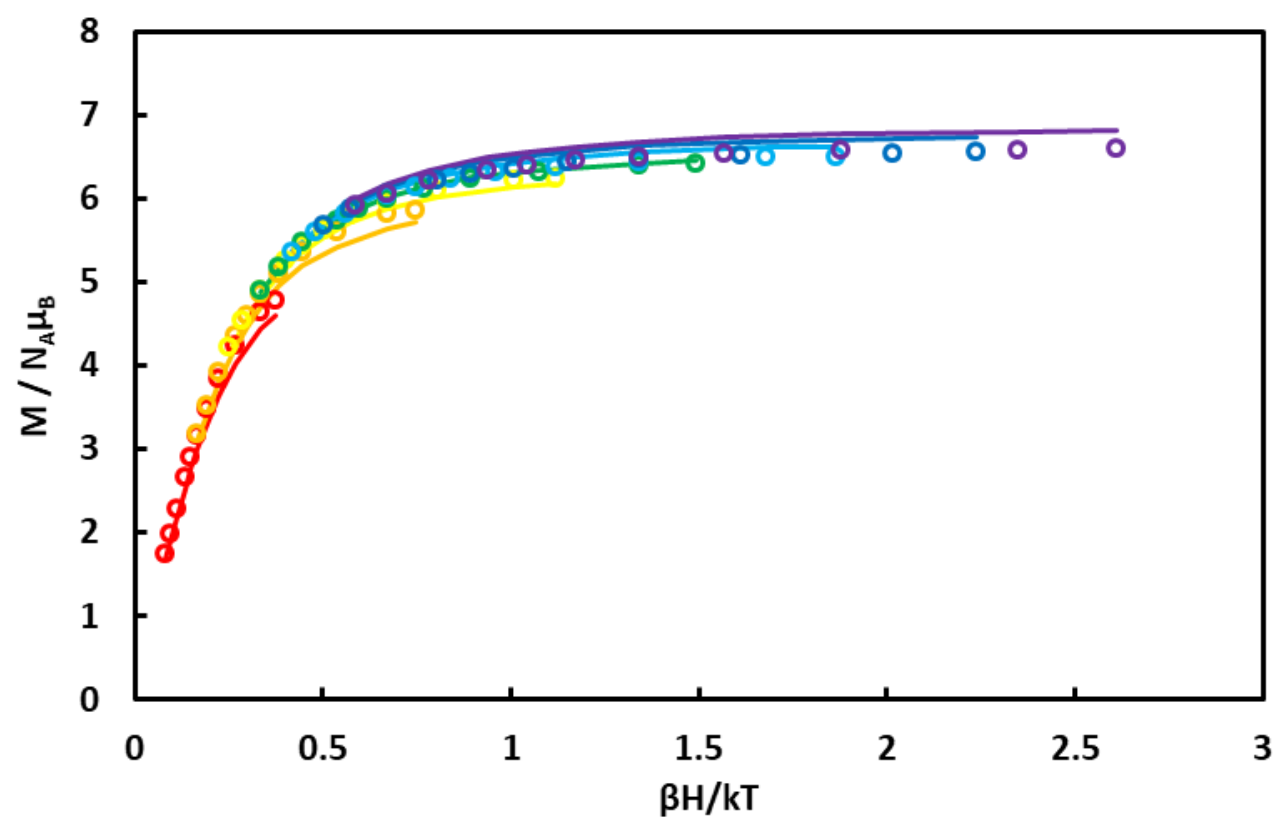

Figure S70. Reduced magnetization data for $\left[\mathrm{LFe}_{3} \mathrm{O}\left({ }^{\mathrm{pNMe} 2} \mathrm{ArIm}\right)_{3} \mathrm{Fe}\right][\mathrm{OTf}]\left(\mathbf{2}^{\mathrm{NMe} 2}\right)$ collected between 1.8 and $8 \mathrm{~K}$ at field between 1 and $7 \mathrm{~T}$ (colored circles). Simulation according to the system spin Hamiltonian $H=D S_{z}{ }^{2}+E\left(S_{x}{ }^{2}+S_{y}{ }^{2}\right)+g \mu_{B} \mathbf{S} \cdot \mathbf{H}$ with $S=7 / 2, g=2.00, D=0.65 \mathrm{~cm}^{-}$ ${ }^{1},|E / D|=0$. 


\section{EPR Spectroscopy}

Details for $\left[\mathrm{LFe}_{3} \mathrm{O}\left({ }^{\mathrm{pCF}} \mathrm{ArIm}\right)_{3} \mathrm{Fe}\right][\mathrm{OTf}]_{2}\left(1^{\mathrm{CF} 3}\right)$ and $\left[\mathrm{LFe}_{3} \mathrm{O}\left({ }^{\mathrm{pNMe} 2} \mathrm{ArIm}\right)_{3} \mathrm{Fe}\right][\mathrm{OTf}]_{2}\left(1^{\mathrm{NMe} 2}\right)$ : Integer spin EPR signals may be observed when electronic levels of a spin multiplet are separated in zero field by an energy $\Delta<\mathrm{h} v\left(0.3 \mathrm{~cm}^{-1}\right.$ at $\mathrm{X}$-band). The EPR spectra of $\left[\mathrm{LFe}_{3} \mathrm{O}\left({ }^{\mathrm{pCF}} \mathrm{ArIm}\right)_{3} \mathrm{Fe}\right][\mathrm{OTf}]_{2}\left(\mathbf{1}^{\mathrm{CF} 3}\right)$ and $\left[\mathrm{LFe}_{3} \mathrm{O}\left({ }^{\mathrm{pNMe} 2} \mathrm{ArIm}\right)_{3} \mathrm{Fe}\right][\mathrm{OTf}]_{2}\left(\mathbf{1}^{\mathrm{NMe} 2}\right)$, collected in parallel mode at $4.5 \mathrm{~K}$ in a propionitrile/butryonitrile (4:5) glass, exhibit a feature at $\mathrm{g} \sim 17.2$. These features have maximum intensity at low temperature and cannot be observed in perpendicular mode, demonstrating that they originate from the ground doublet of an integer spin system. As line broadening in the EPR spectra of integer spin systems are dominated by strain in the zero field splitting parameters $D$ and $E$ (and thus $\Delta$ ), the narrow linewidth of the $\mathrm{g} \sim 17.2$ feature is consistent with this ground doublet being nearly degenerate ${ }^{45-49}$ For an EPR transition within the $M_{s}=+/-4$ doublet of an $S=4$ spin system, the resonance field position depends on both the zero field splitting and the Zeeman interaction according to $(\mathrm{h} v)^{2}=\Delta^{2}+\left(\mathrm{g} \mu_{\mathrm{B}} \mathrm{H}\right)^{2} .{ }^{50} \mathrm{~A}$ nearly identical feature was previously observed in the parallel mode EPR spectrum of $\left[\mathrm{LFe}_{3} \mathrm{O}(\mathrm{PhIm})_{3} \mathrm{Fe}\right][\mathrm{OTf}]_{2}\left(\mathbf{1}^{\mathbf{H}}\right)$ which was shown to have an $S=4$ ground state with $D<0$ by a host of spectroscopic techniques. ${ }^{5}$

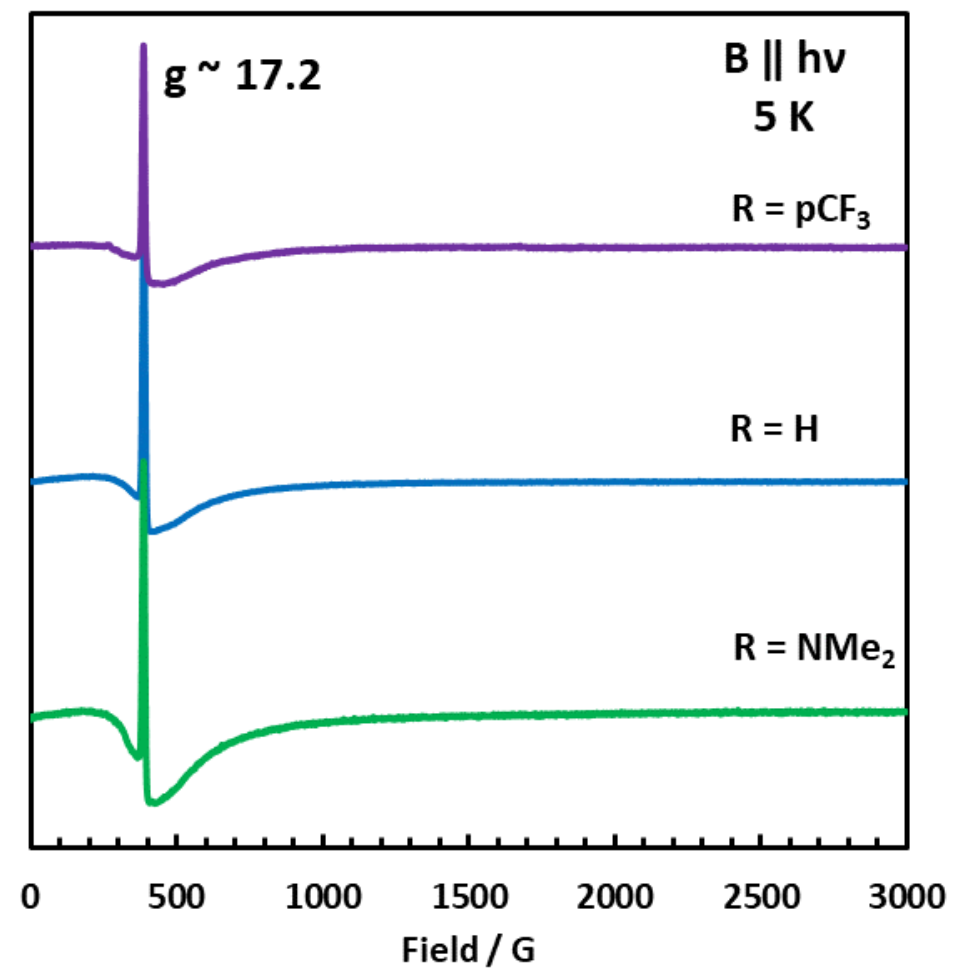

Figure S71. Parallel-mode EPR Spectra of $\left[\mathrm{LFe}_{3} \mathrm{O}\left({ }^{\mathrm{pCF}} \mathrm{ArIm}\right)_{3} \mathrm{Fe}\right][\mathrm{OTf}]_{2}\left(\mathbf{1}^{\mathrm{CF} 3}\right.$, purple), $\left[\mathrm{LFe}_{3} \mathrm{O}(\mathrm{PhIm})_{3} \mathrm{Fe}\right][\mathrm{OTf}]_{2}\left(\mathbf{1}^{\mathbf{H}}\right.$, blue $)$ and $\left[\mathrm{LFe}_{3} \mathrm{O}\left({ }^{\left(\mathrm{pNMe}^{2}\right.} \mathrm{ArIm}\right)_{3} \mathrm{Fe}\right][\mathrm{OTf}]_{2}\left(\mathbf{1}^{\mathrm{NMe} 2}\right.$, green $)$ at $4.5 \mathrm{~K}$ in a propionitrile/butryonitrile (4:5) glass. 


\section{Mössbauer Spectroscopy}

General Mössbauer Simulation Details. All spectra were simulated by four pairs of symmetric quadrupole doublets with equal populations and Lorentzian lineshapes, and refined to a minimum by the method of least squares optimization (a total of 13 fitting parameters per spectrum). For all spectra, the observed resonances spanned the region from $-1-3 \mathrm{~mm} / \mathrm{s}$. Any resonances appearing above $2 \mathrm{~mm} / \mathrm{s}$ indicate the presence of high spin Fe(II) centers and must correspond to species with isomer shifts $\sim 1 \mathrm{~mm} / \mathrm{s}$, given the range of observed resonances. Details regarding the fitting of individual spectra are given below. In short, the Mössbauer data were modeled to be consistent with our previously reported triiron-oxo/hydroxyl clusters, ${ }^{51}$ and our previously reported tetranuclear iron clusters. ${ }^{52}$ Overall, the observed Mössbauer parameters for the irons in the trimetallic core are in-line with those of other six-coordinate $\mathrm{Fe}^{\mathrm{II}} / \mathrm{Fe}^{\mathrm{III}}$ centers bearing $\mathrm{N}$ - and $\mathrm{O}$ donor atoms. ${ }^{35,53-57}$

Simulation Details for $\left[\mathrm{LFe}_{3} \mathrm{O}\left({ }^{\mathrm{pCF} 3} \mathrm{ArIm}\right)_{3} \mathrm{Fe}\right][\mathrm{OTf}]_{2}\left(1^{\mathrm{CF} 3}\right)$ : The zero-field Mössbauer spectrum $(80 \mathrm{~K})$ of $\mathbf{1}^{\mathbf{C F} 3}$ is nearly identical to that reported for $\mathbf{1}^{\mathbf{H}}$, indicating a common electronic structure in both clusters. Based on their characteristic Mössbauer parameters, the asymmetric Lorentzian feature near $3 \mathrm{~mm} / \mathrm{s}$ suggests the presence of at least high spin, six-coordinate ferrous centers. Moreover, the sharp resonances near $0.25 \mathrm{~mm} / \mathrm{s}$ and $0.70 \mathrm{~mm} / \mathrm{s}$ suggest the presence of two Fe ${ }^{\mathrm{III}}$ centers with distinct isomer shifts and/or quadrupole splittings. Indeed, simulation of the experimental spectrum assuming three distinct iron subsites in a 2:1:1 ratio results in two reasonable models, both of which afford Mössbauer parameters for one subsite $\left(\delta \sim 1 \mathrm{~mm} / \mathrm{s},\left|\Delta E_{\mathrm{Q}}\right|\right.$ $\sim 3 \mathrm{~mm} / \mathrm{s}, 50 \%$ total iron) indicative of two high spin, six-coordinate $\mathrm{Fe}^{\mathrm{II}}$ centers in the basal triiron core. Depending on how the resonances near 0.25 and $0.70 \mathrm{~mm} / \mathrm{s}$ are modelled, the isomer shift of one of the subsites $(\delta=0.36-0.50 \mathrm{~mm} / \mathrm{s}, 25 \%$ total iron) is consistent with the presence of one sixcoordinate, high spin $\mathrm{Fe}^{\mathrm{III}}$ center in an $\mathrm{O} / \mathrm{N}$ rich ligand environment. ${ }^{35,53-57}$ The quadrupole doublet of the remaining subsite has a significantly lower isomer shift $(\delta=0.03-0.25 \mathrm{~mm} / \mathrm{s})$. Sixcoordinate ferric iron complexes are not known to exhibit isomer shifts in this range, suggesting either a low-spin assignment for the remaining $\mathrm{Fe}^{\mathrm{III}}$ center or a lower coordinate, highly covalent ligand field. SQUID magnetometry and EPR spectroscopy indicate an $S=4$ ground state for $\mathbf{1}^{\mathbf{C F} 3}$, which rules out the presence of low- or intermediate-spin ferric centers. Hence, the final model, obtained after splitting the quadrupole doublet for the core $\mathrm{Fe}^{\mathrm{II}}$ subsite into two and allowing each to refine independently, affords an isomer shift of $0.19 \mathrm{~mm} / \mathrm{s}\left(\left|\Delta E_{\mathrm{Q}}\right|=1.24 \mathrm{~mm} / \mathrm{s}\right.$ for the apical ferric site of $\mathbf{1}^{\mathbf{C F} 3}$, in line with values reported for high spin, four coordinate $\mathrm{Fe}^{\mathrm{III}}$ centers. ${ }^{58-63}$ 


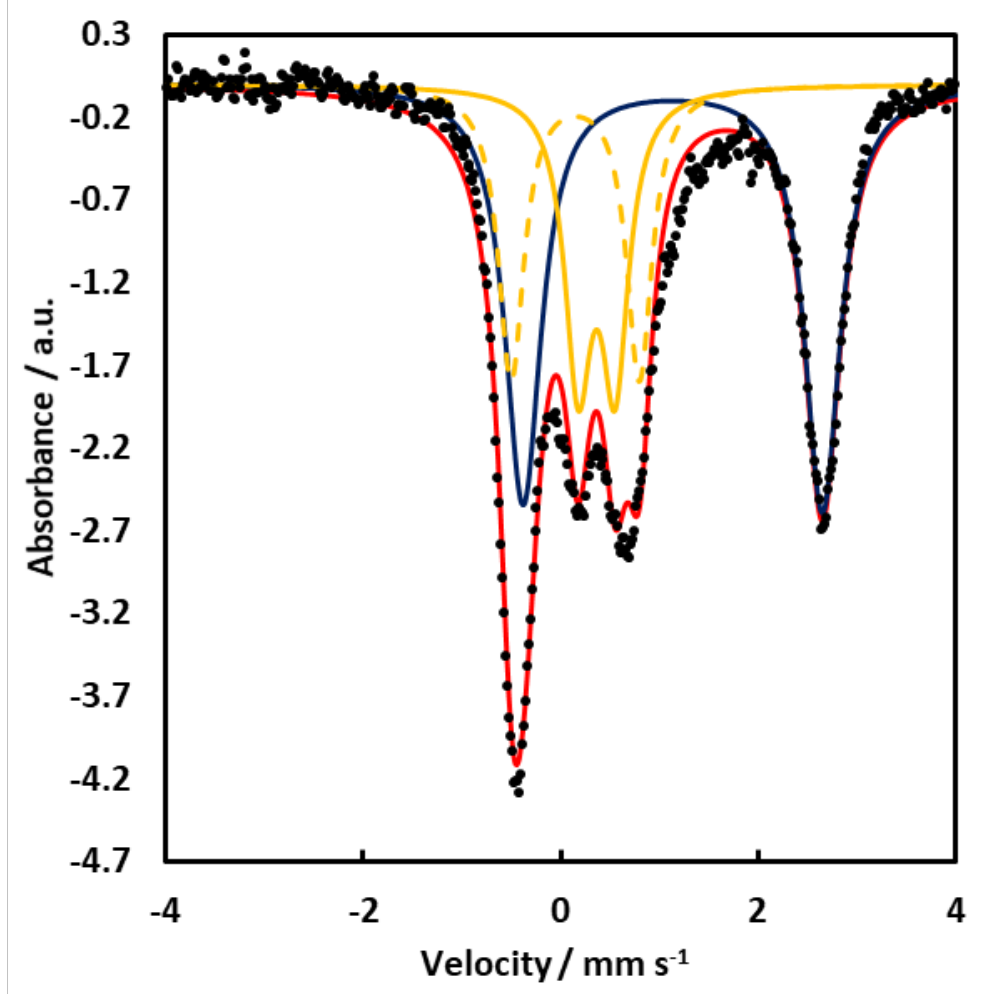

Figure S72. Zero field ${ }^{57} \mathrm{Fe}$ Mössbauer spectra $(80 \mathrm{~K})$ of $\left[\mathrm{LFe}_{3} \mathrm{O}\left({ }^{\mathrm{pCF}} \mathrm{ArIm}\right)_{3} \mathrm{Fe}\right][\mathrm{OTf}]_{2}\left(\mathbf{1}^{\mathrm{CF} 3}\right.$, microcrystalline material, black dots). The simulation assuming three distinct subsites is shown in red, with parameters: (i): $\delta=1.14 \mathrm{~mm} / \mathrm{s},\left|\Delta \mathrm{E}_{\mathrm{Q}}\right|=3.04 \mathrm{~mm} / \mathrm{s}$ (solid blue trace, $50 \%$ ); (ii): $\delta=0.36$ $\mathrm{mm} / \mathrm{s},\left|\Delta \mathrm{E}_{\mathrm{Q}}\right|=0.37 \mathrm{~mm} / \mathrm{s}$ (solid orange trace, $25 \%$ ); (iii): $\delta=0.15 \mathrm{~mm} / \mathrm{s},\left|\Delta \mathrm{E}_{\mathrm{Q}}\right|=1.30 \mathrm{~mm} / \mathrm{s}$ (dashed orange trace, $25 \%$ ). 


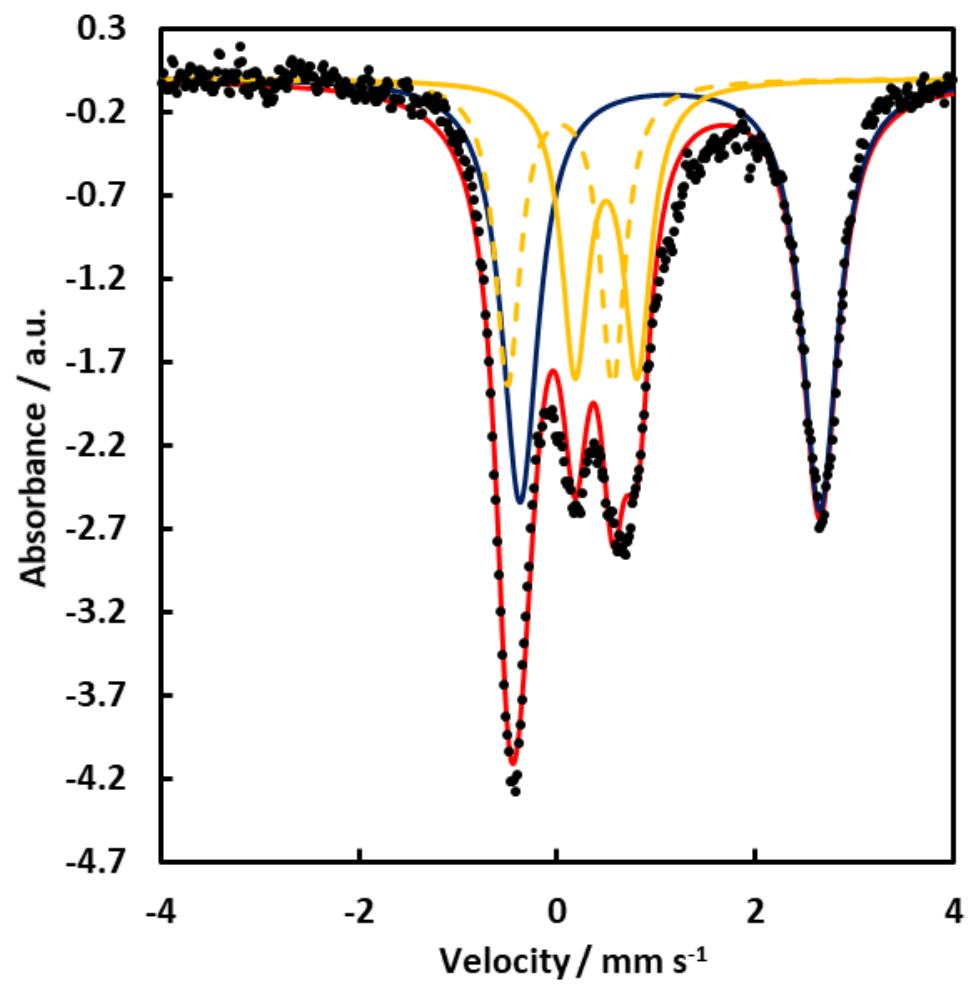

Figure S73. Zero field ${ }^{57} \mathrm{Fe}$ Mössbauer spectra $(80 \mathrm{~K})$ of $\left[\mathrm{LFe}_{3} \mathrm{O}\left({ }^{\mathrm{PCF}} \mathrm{ArIm}\right)_{3} \mathrm{Fe}\right][\mathrm{OTf}]_{2}\left(\mathbf{1}^{\mathrm{CF} 3}\right.$, microcrystalline material, black dots). The simulation assuming three distinct subsites is shown in red, with parameters: (i): $\delta=1.14 \mathrm{~mm} / \mathrm{s},\left|\Delta \mathrm{E}_{\mathrm{Q}}\right|=3.03 \mathrm{~mm} / \mathrm{s}$ (solid blue trace, $50 \%$ ); (ii): $\delta=0.50$ $\mathrm{mm} / \mathrm{s},\left|\Delta \mathrm{E}_{\mathrm{Q}}\right|=0.63 \mathrm{~mm} / \mathrm{s}$ (solid orange trace, $25 \%$ ); (iii): $\delta=0.03 \mathrm{~mm} / \mathrm{s},\left|\Delta \mathrm{E}_{\mathrm{Q}}\right|=1.06 \mathrm{~mm} / \mathrm{s}$ (dashed orange trace, $25 \%$ ). 


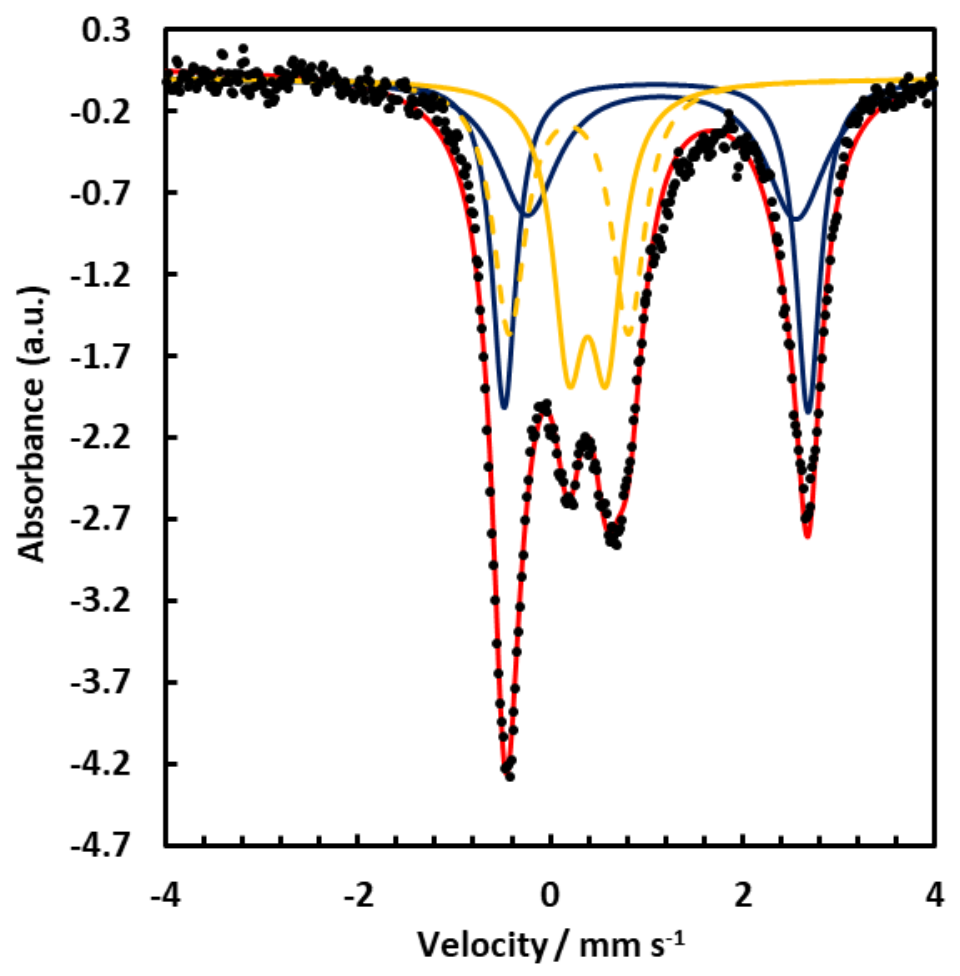

Figure S74. Zero field ${ }^{57} \mathrm{Fe}$ Mössbauer spectra $(80 \mathrm{~K})$ of $\left[\mathrm{LFe}_{3} \mathrm{O}\left({ }^{\mathrm{pCF} 3} \mathrm{ArIm}\right)_{3} \mathrm{Fe}\right][\mathrm{OTf}]_{2}\left(\mathbf{1}^{\text {CF3 }}\right.$, microcrystalline material, black dots). The simulation assuming four distinct subsites is shown in red, with parameters: (i): $\delta=1.10 \mathrm{~mm} / \mathrm{s},\left|\Delta \mathrm{E}_{\mathrm{Q}}\right|=3.17 \mathrm{~mm} / \mathrm{s}$ (solid blue trace, $25 \%$ ); (ii): $\delta=1.16$ $\mathrm{mm} / \mathrm{s},\left|\Delta \mathrm{E}_{\mathrm{Q}}\right|=2.80 \mathrm{~mm} / \mathrm{s}$ (solid blue trace, $25 \%$ ); (iii): $\delta=0.39 \mathrm{~mm} / \mathrm{s},\left|\Delta \mathrm{E}_{\mathrm{Q}}\right|=0.39 \mathrm{~mm} / \mathrm{s}$ (solid orange trace, $25 \%$ ); (iv): $\delta=0.19 \mathrm{~mm} / \mathrm{s},\left|\Delta \mathrm{E}_{\mathrm{Q}}\right|=1.24 \mathrm{~mm} / \mathrm{s}$ (dashed orange trace, $25 \%$ ). 
Simulation Details for $\left[\mathrm{LFe}_{3} \mathrm{O}\left({ }^{\mathrm{pNMe} 2} \mathrm{ArIm}\right)_{3} \mathrm{Fe}\right][\mathrm{OTf}]_{2}\left(\mathbf{1}^{\mathrm{NMe} 2}\right)$ : The Mössbauer spectrum of $\mathbf{1}^{\mathrm{NMe} 2}$ is nearly identical (albeit substantially broader) to that reported previously for $\left[\mathrm{LFe}_{3} \mathrm{O}(\mathrm{PhIm})_{3} \mathrm{Fe}\right][\mathrm{OTf}]_{2}\left(\mathbf{1}^{\mathbf{N M e}}\right)$ and was fit similarly.

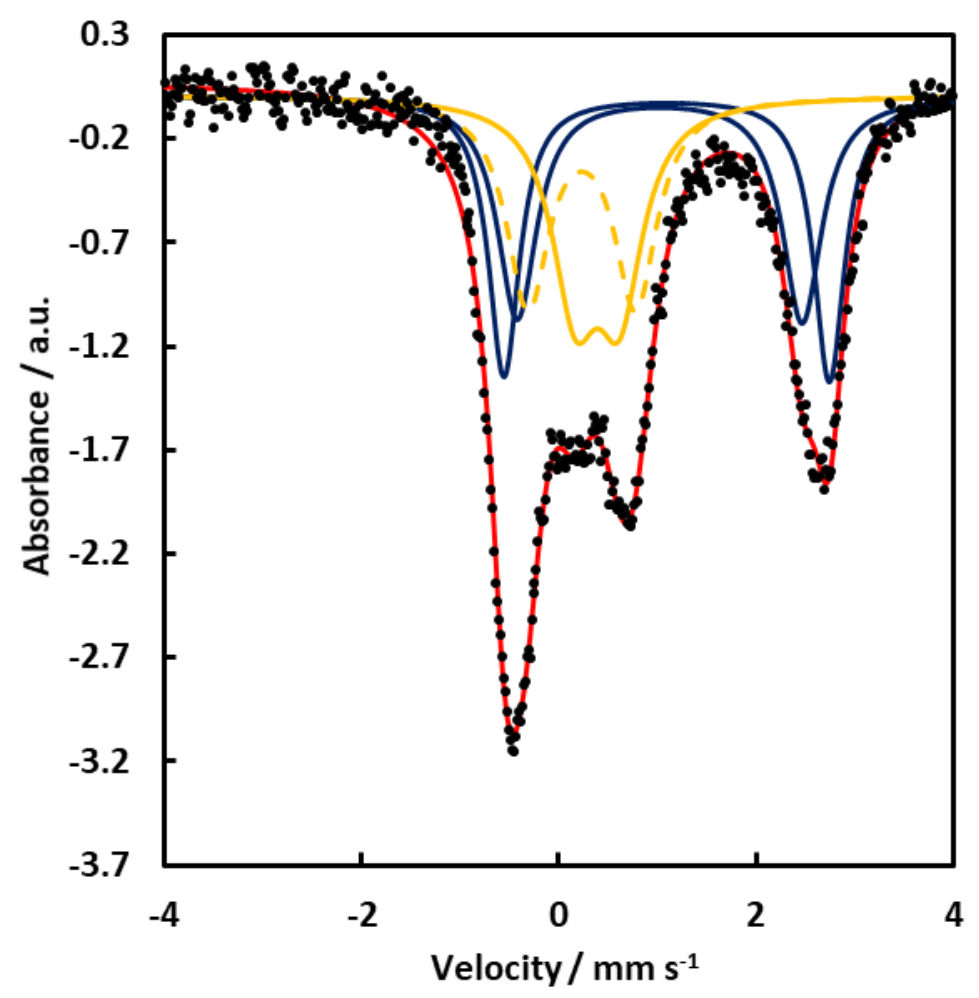

Figure S75. Zero field ${ }^{57} \mathrm{Fe}$ Mössbauer spectra $(80 \mathrm{~K})$ of $\left[\mathrm{LFe}_{3} \mathrm{O}\left({ }^{\mathrm{pNMe} 2} \mathrm{ArIm}\right)_{3} \mathrm{Fe}\right][\mathrm{OTf}]_{2}\left(\mathbf{1}^{\mathrm{NMe} 2}\right.$, microcrystalline material, black dots). The simulation assuming four distinct subsites is shown in red, with parameters: (i): $\delta=1.02 \mathrm{~mm} / \mathrm{s},\left|\Delta \mathrm{E}_{\mathrm{Q}}\right|=2.89 \mathrm{~mm} / \mathrm{s}$ (solid blue trace, $25 \%$ ); (ii): $\delta=1.09$ $\mathrm{mm} / \mathrm{s},\left|\Delta \mathrm{E}_{\mathrm{Q}}\right|=3.30 \mathrm{~mm} / \mathrm{s}$ (solid blue trace, $25 \%$ ); (iii): $\delta=0.39 \mathrm{~mm} / \mathrm{s},\left|\Delta \mathrm{E}_{\mathrm{Q}}\right|=0.45 \mathrm{~mm} / \mathrm{s}$ (solid orange trace, $25 \%$ ); (iv): $\delta=0.22 \mathrm{~mm} / \mathrm{s},\left|\Delta \mathrm{E}_{\mathrm{Q}}\right|=1.10 \mathrm{~mm} / \mathrm{s}$ (dashed orange trace, $25 \%$ ).

Simulation Details for $\left.\left[\mathrm{LFe}_{3} \mathrm{O}\left({ }^{\mathrm{pCF} 3} \mathrm{ArIm}\right)\right)_{3} \mathrm{Fe}\right][\mathrm{OTf}]\left(2^{\mathrm{CF} 3}\right)$ : The Mössbauer spectrum of $2^{\mathrm{CF} 3}(80$ K) features only three well-resolved resonances, albeit with discernable shoulders near the Lorentzian features around $-0.5 \mathrm{~mm} / \mathrm{s}$ and $3 \mathrm{~mm} / \mathrm{s}$, respectively. A satisfactory simulation of the experimental spectrum requires at least three distinct iron subsites which, based on the relative intensity of the resonance near $3 \mathrm{~mm} / \mathrm{s}$, occur in a 2:1:1 ratio. Two reasonable simulations were obtained, both of which afford Mössbauer parameters for one subsite (50\% total iron) which are consistent with the presence of two high spin, six-coordinate $\mathrm{Fe}^{\mathrm{II}}$ centers $\left(\delta \sim 1.1 \mathrm{~mm} / \mathrm{s},\left|\Delta E_{\mathrm{Q}}\right| \sim\right.$ $3.2 \mathrm{~mm} / \mathrm{s}$ ) within the triiron core. ${ }^{5,52,64-67}$ The relative intensity of the sharp resonance near $1 \mathrm{~mm} / \mathrm{s}$ indicates the presence of one ferric ion whose isomer shift and quadrupole splitting depend on how the Lorentzian feature near $-0.5 \mathrm{~mm} / \mathrm{s}$ is modelled, with $\delta$ bounded between $0.34-0.47 \mathrm{~mm} / \mathrm{s}$. Isomer shifts in this range are common for high spin, six-coordinate ferric centers in $\mathrm{O} / \mathrm{N}$ rich ligand environments, ${ }^{35,54-56,68}$ suggesting a $\left[\mathrm{Fe}^{\mathrm{II}}{ }_{2} \mathrm{Fe}^{\mathrm{III}}\right]$ redox level for the triiron core identical to that inferred from the solid state structure. The shoulder observed to the left of the Lorentzian feature around $3 \mathrm{~mm} / \mathrm{s}$ is attributed a third ferrous site with a lower isomer shift $(\delta \sim 0.8 \mathrm{~mm} / \mathrm{s})$ and lower quadrupole splitting $\left(\left|\Delta E_{\mathrm{Q}}\right| \sim 2.7 \mathrm{~mm} / \mathrm{s}\right)$. A similar shoulder is observed in the Mössbauer 
spectra of $2^{\mathbf{H} 5}$ and $\left[\mathrm{LFe}_{3} \mathrm{O}(\mathrm{PhPz})_{3} \mathrm{Fe}\right][\mathrm{OTf}]^{52}$ and has been assigned to a resonance of the apical $\mathrm{Fe}^{\mathrm{II}}$ center. The favored simulation of the Mössbauer spectrum of $\mathbf{2}^{\mathrm{H}}$ was originally selected based on the similarity of the Mössbauer parameters obtained for apical $\mathrm{Fe}^{\mathrm{II}}$ center of $\mathbf{2}^{\mathbf{H}}(\delta=0.89 \mathrm{~mm} / \mathrm{s})$ compared to $\left[\mathrm{LFe}_{3} \mathrm{O}(\mathrm{PhPz})_{3} \mathrm{Fe}\right][\mathrm{OTf}](\delta=0.95 \mathrm{~mm} / \mathrm{s})$ and an equivalent fit can be obtained for $2^{\text {CF3 }}$. However, due to its softer (C rich) ligand environment, a smaller isomer shift is anticipated for the apical ferrous site of $\mathbf{2}^{\mathbf{C F} 3}$ and $\mathbf{2}^{\mathbf{H}}$ compared to $\left[\mathrm{LFe}_{3} \mathrm{O}(\mathrm{PhPz})_{3} \mathrm{Fe}\right][\mathrm{OTf}]{ }^{58}$ Indeed, fourcoordinate, high spin $\mathrm{Fe}^{\mathrm{II}}$ centers supported by multidentate $N$-heterocyclic carbene ligand scaffolds are reported to have isomer shifts of $\sim 0.70 \mathrm{~mm} / \mathrm{s} .{ }^{69-70}$ A similar value $(\delta=0.68 \mathrm{~mm} / \mathrm{s})$ was observed for the apical $\mathrm{Fe}^{\mathrm{II}}$ center of $\left[\mathrm{LFe}_{3} \mathrm{O}(\mathrm{PhIm})_{3} \mathrm{Fe}\right]$, whose spectrum is not complicated by the presence of ferric iron signals. ${ }^{5}$ With these considerations in mind, the final model, obtained after splitting the quadrupole doublet for the core $\mathrm{Fe}(\mathrm{II})$ subsite into two and allowing each to refine independently, affords an isomer shift of $0.73 \mathrm{~mm} / \mathrm{s}\left(\left|\Delta E_{\mathrm{Q}}\right| \sim 2.76 \mathrm{~mm} / \mathrm{s}\right)$ for the trigonal pyramidal ferrous site of $\mathbf{2}^{\mathrm{CF} 3}$. A similar fit can be obtained for $\mathbf{2}^{\mathrm{H}}$ and is presented here as well.

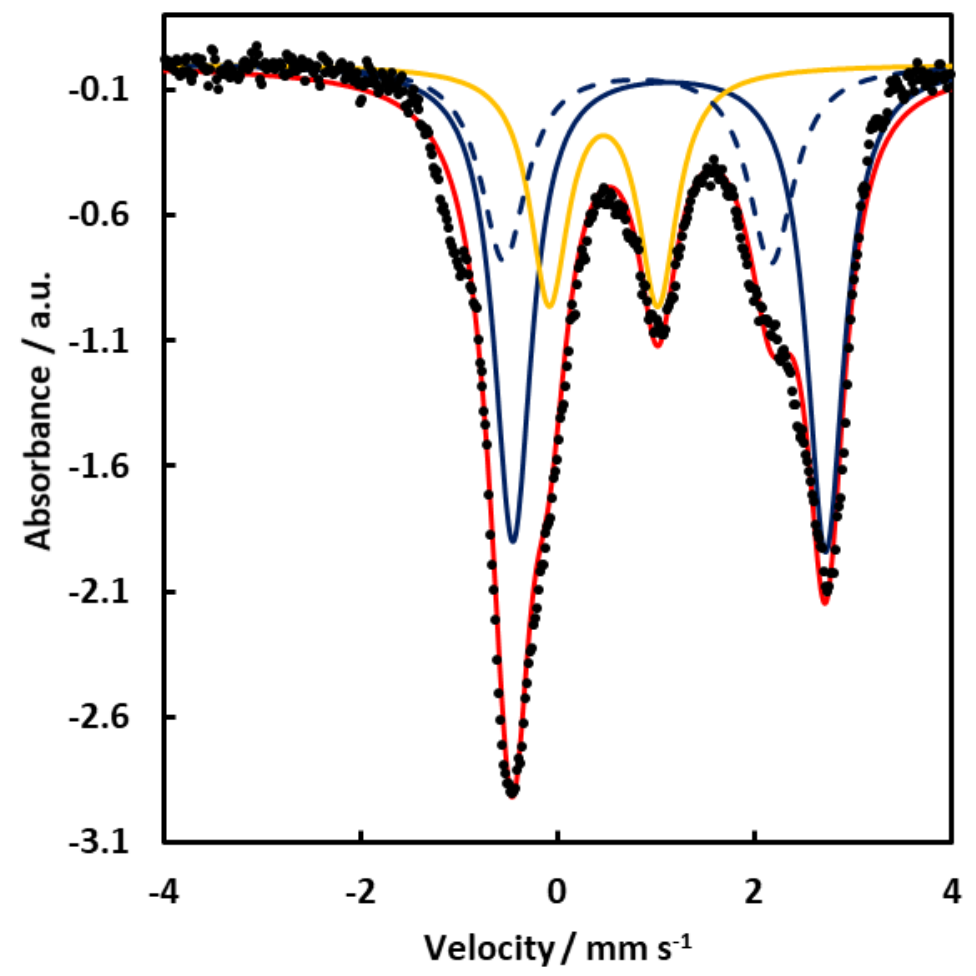

Figure S76. Zero field ${ }^{57} \mathrm{Fe}$ Mössbauer spectra $(80 \mathrm{~K})$ of $\left[\mathrm{LFe}_{3} \mathrm{O}\left({ }^{\mathrm{pCF}} \mathrm{ArIm}\right)_{3} \mathrm{Fe}\right][\mathrm{OTf}]\left(2^{\mathrm{CF} 3}\right.$, microcrystalline material, black dots). The simulation assuming three distinct subsites is shown in red, with parameters: (i): $\delta=1.14 \mathrm{~mm} / \mathrm{s},\left|\Delta \mathrm{E}_{\mathrm{Q}}\right|=3.17 \mathrm{~mm} / \mathrm{s}$ (solid blue trace, $50 \%$ ); (ii): $\delta=0.47$ $\mathrm{mm} / \mathrm{s},\left|\Delta \mathrm{E}_{\mathrm{Q}}\right|=1.10 \mathrm{~mm} / \mathrm{s}$ (solid orange trace, $25 \%$ ); (iii): $\delta=0.81 \mathrm{~mm} / \mathrm{s},\left|\Delta \mathrm{E}_{\mathrm{Q}}\right|=2.71 \mathrm{~mm} / \mathrm{s}$ (dashed blue trace, $25 \%$ ). 


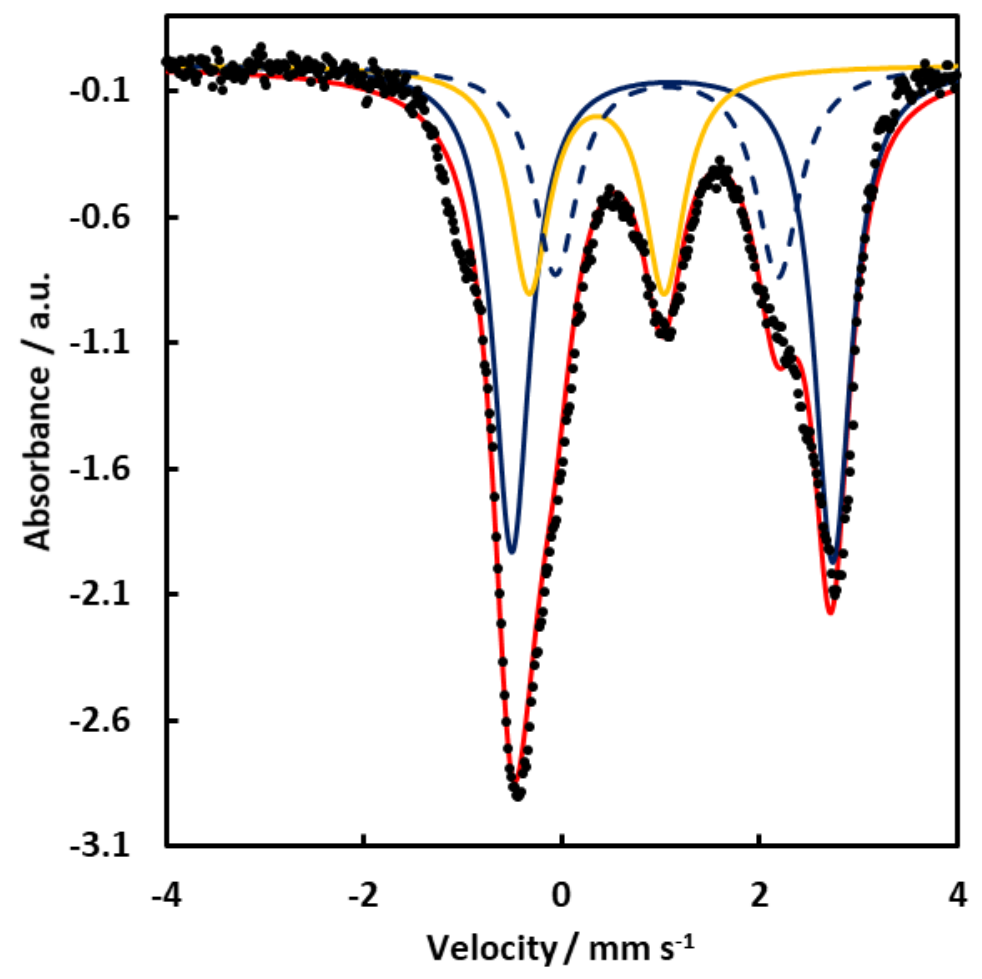

Figure S77. Zero field ${ }^{57} \mathrm{Fe}$ Mössbauer spectra $(80 \mathrm{~K})$ of $\left[\mathrm{LFe}_{3} \mathrm{O}\left({ }^{\mathrm{pCF} 3} \mathrm{ArIm}\right){ }_{3} \mathrm{Fe}\right][\mathrm{OTf}]\left(\mathbf{2}^{\mathrm{CF} 3}\right.$, microcrystalline material, black dots). The simulation assuming three distinct subsites is shown in red, with parameters: (i): $\delta=1.10 \mathrm{~mm} / \mathrm{s},\left|\Delta \mathrm{E}_{\mathrm{Q}}\right|=3.25 \mathrm{~mm} / \mathrm{s}$ (solid blue trace, $50 \%$ ); (ii): $\delta=$ $0.34 \mathrm{~mm} / \mathrm{s},\left|\Delta \mathrm{E}_{\mathrm{Q}}\right|=1.37 \mathrm{~mm} / \mathrm{s}$ (solid orange trace, $25 \%$ ); (iii): $\delta=1.05 \mathrm{~mm} / \mathrm{s},\left|\Delta \mathrm{E}_{\mathrm{Q}}\right|=2.25 \mathrm{~mm} / \mathrm{s}$ (dashed blue trace, 25\%). 


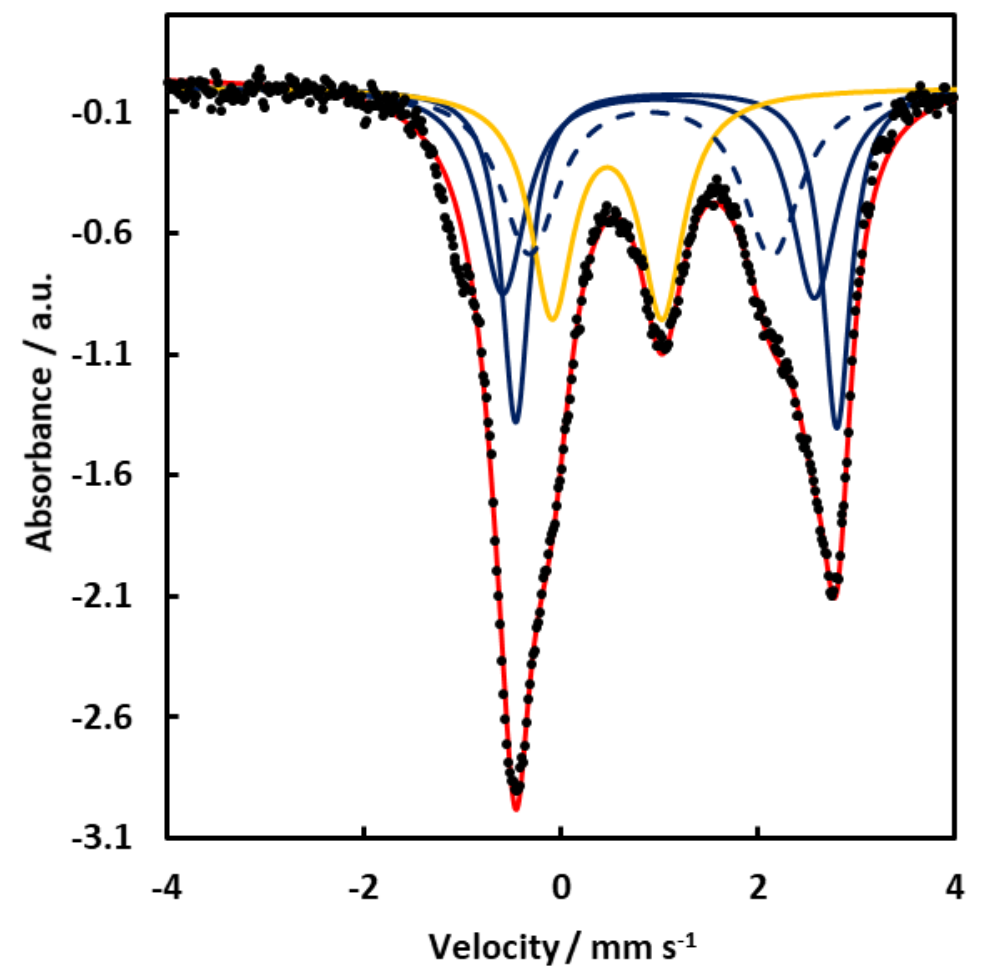

Figure S78. Zero field ${ }^{57} \mathrm{Fe}$ Mössbauer spectra $(80 \mathrm{~K})$ of $\left[\mathrm{LFe}_{3} \mathrm{O}\left({ }^{\mathrm{pCF}} \mathrm{ArIm}\right){ }_{3} \mathrm{Fe}\right][\mathrm{OTf}]\left(\mathbf{2}^{\mathrm{CF} 3}\right.$, microcrystalline material, black dots). The simulation assuming four distinct subsites is shown in red, with parameters: (i): $\delta=0.99 \mathrm{~mm} / \mathrm{s},\left|\Delta \mathrm{E}_{\mathrm{Q}}\right|=3.17 \mathrm{~mm} / \mathrm{s}$ (solid blue trace, $25 \%$ ); (ii): $\delta=1.17$ $\mathrm{mm} / \mathrm{s},\left|\Delta \mathrm{E}_{\mathrm{Q}}\right|=3.26 \mathrm{~mm} / \mathrm{s}$ (solid blue trace, $25 \%$ ); (iii): $\delta=0.46 \mathrm{~mm} / \mathrm{s},\left|\Delta \mathrm{E}_{\mathrm{Q}}\right|=1.12 \mathrm{~mm} / \mathrm{s}$ (solid orange trace, $25 \%$ ); (iv): $\delta=0.90 \mathrm{~mm} / \mathrm{s},\left|\Delta \mathrm{E}_{\mathrm{Q}}\right|=2.46 \mathrm{~mm} / \mathrm{s}$ (dashed blue trace, $25 \%$ ). 


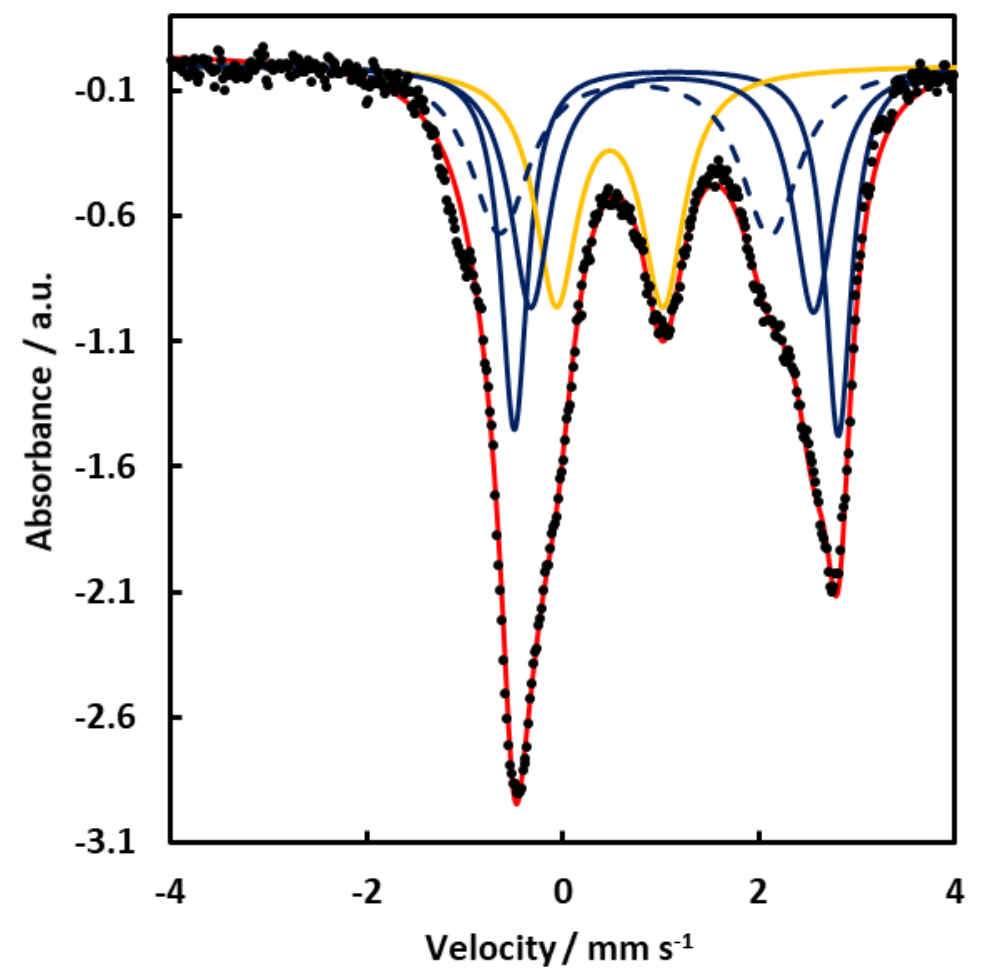

Figure S79. Zero field ${ }^{57} \mathrm{Fe}$ Mössbauer spectra $(80 \mathrm{~K})$ of $\left[\mathrm{LFe}_{3} \mathrm{O}\left({ }^{\mathrm{pCF}} \mathrm{ArIm}\right){ }_{3} \mathrm{Fe}\right][\mathrm{OTf}]\left(\mathbf{2}^{\mathbf{C F 3}}\right.$, microcrystalline material, black dots). The simulation assuming four distinct subsites is shown in red, with parameters: (i): $\delta=1.11 \mathrm{~mm} / \mathrm{s},\left|\Delta \mathrm{E}_{\mathrm{Q}}\right|=2.88 \mathrm{~mm} / \mathrm{s}$ (solid blue trace, $25 \%$ ); (ii): $\delta=1.15$ $\mathrm{mm} / \mathrm{s},\left|\Delta \mathrm{E}_{\mathrm{Q}}\right|=3.31 \mathrm{~mm} / \mathrm{s}$ (solid blue trace, $25 \%$ ); (iii): $\delta=0.47 \mathrm{~mm} / \mathrm{s},\left|\Delta \mathrm{E}_{\mathrm{Q}}\right|=1.09 \mathrm{~mm} / \mathrm{s}$ (solid orange trace, $25 \%$ ); (iv): $\delta=0.73 \mathrm{~mm} / \mathrm{s},\left|\Delta \mathrm{E}_{\mathrm{Q}}\right|=2.76 \mathrm{~mm} / \mathrm{s}$ (dashed blue trace, $25 \%$ ). 


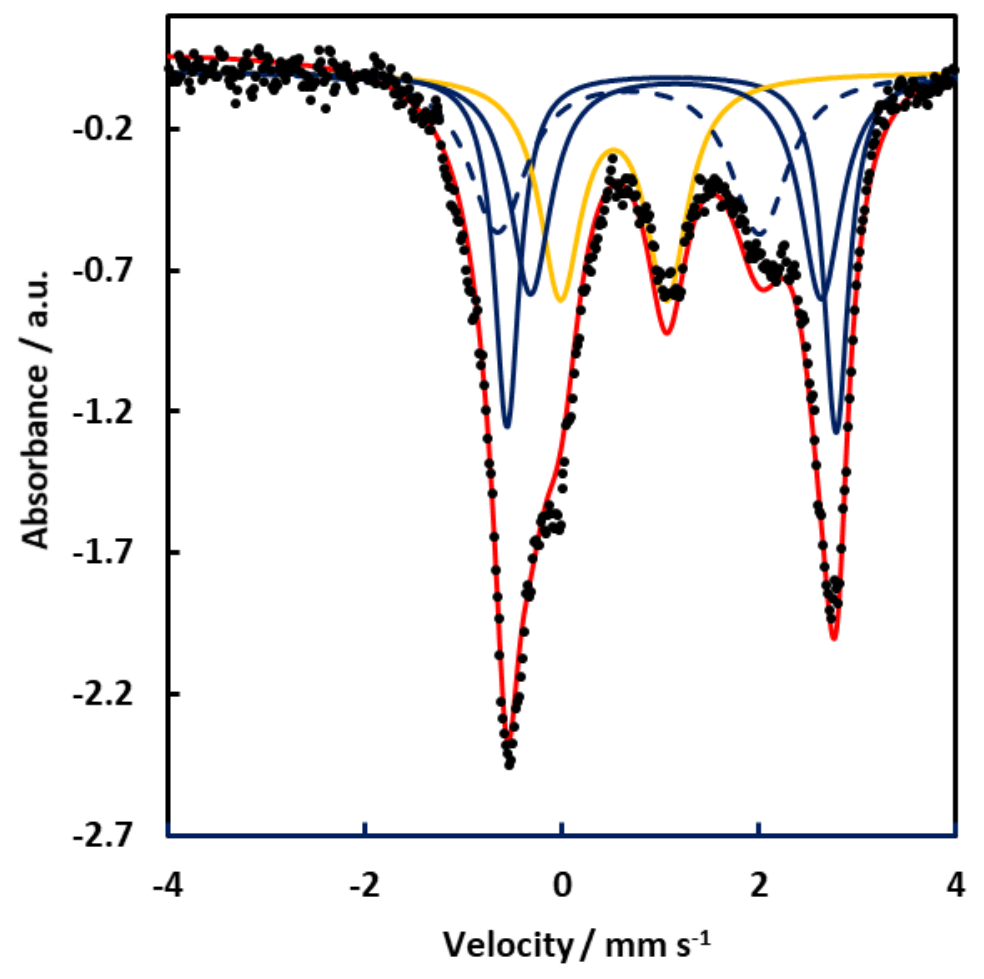

Figure S80. Zero field ${ }^{57} \mathrm{Fe}$ Mössbauer spectra $(80 \mathrm{~K})$ of $\left[\mathrm{LFe}_{3} \mathrm{O}(\mathrm{PhIm})_{3} \mathrm{Fe}\right][\mathrm{OTf}]\left(\mathbf{2}^{\mathbf{H}}\right.$, microcrystalline material, black dots). The simulation assuming four distinct subsites is shown in red, with parameters: (i): $\delta=1.12 \mathrm{~mm} / \mathrm{s},\left|\Delta \mathrm{E}_{\mathrm{Q}}\right|=3.34 \mathrm{~mm} / \mathrm{s}$ (solid blue trace, $25 \%$ ); (ii): $\delta=1.17$ $\mathrm{mm} / \mathrm{s},\left|\Delta \mathrm{E}_{\mathrm{Q}}\right|=2.95 \mathrm{~mm} / \mathrm{s}$ (solid blue trace, $25 \%$ ); (iii): $\delta=0.53 \mathrm{~mm} / \mathrm{s},\left|\Delta \mathrm{E}_{\mathrm{Q}}\right|=1.08 \mathrm{~mm} / \mathrm{s}$ (solid orange trace, $25 \%$ ); (iv): $\delta=0.68 \mathrm{~mm} / \mathrm{s},\left|\Delta \mathrm{E}_{\mathrm{Q}}\right|=2.66 \mathrm{~mm} / \mathrm{s}$ (dashed blue trace, $25 \%$ ).

Simulation Details for $\left[\mathrm{LFe}_{3} \mathrm{O}\left({ }^{\left({ }^{N M e}\right.} \mathrm{ArIm}\right)_{3} \mathrm{Fe}\right][\mathrm{OTf}]\left(2^{\mathrm{NMe}}\right)$ : In contrast to the qualitatively similar spectra obtained for $\mathbf{2}^{\mathbf{C F} 3}$ and $\mathbf{2}^{\mathbf{H}}$, the distinct Mössbauer spectrum of $\mathbf{2}^{\mathrm{NMe}}$ indicates a change in the electronic structure. The spectrum features only two well resolved resonances, with a broad shoulder to the right of the Lorentzian feature near $-0.5 \mathrm{~mm} / \mathrm{s}$. Most notably, the sharp resonance near $1 \mathrm{~mm} / \mathrm{s}$ observed in the spectra of $\mathbf{2}^{\mathbf{C F} 3}, \mathbf{2}^{\mathbf{H}}$, and $\left[\mathrm{LFe}{ }_{3} \mathrm{O}(\mathrm{PhPz})_{3} \mathrm{Fe}\right][\mathrm{OTf}]$ is absent. Only a sharp, nearly isotropic signal is observed at $0.11 \mathrm{~mm} / \mathrm{s}$, indicating a significantly lower isomer shift for the ferric subsite of $2^{\mathrm{NMe} 2}$. Six-coordinate, high spin Fe $\mathrm{e}^{\mathrm{III}}$ complexes are not known to exhibit isomer shifts lower than $\sim 0.35 \mathrm{~mm} / \mathrm{s}$. As such, the quadrupole doublet for the ferric subsite does not originate from within the triiron core, indicating instead an $\mathrm{Fe}^{\mathrm{III}}$ assignment for the apical metal center consistent with the solid state structure of $\mathbf{2}^{\mathrm{NMe}}$. Indeed, isomer shifts of $\sim 0.20 \mathrm{~mm} / \mathrm{s}$ are commonly observed for four-coordinate, high spin ferric iron complexes in soft ligand environments. ${ }^{59}$ This assignment infers a $\left[\mathrm{Fe}_{3}{ }_{3}\right]$ redox level for the triion core, which is supported spectral simulations which afford Mössbauer parameters of the remaining subsite $(\delta=$ $1.1 \mathrm{~mm} / \mathrm{s},\left|\Delta E_{\mathrm{Q}}\right|=3.23 \mathrm{~mm} / \mathrm{s}, 75 \%$ total iron) consistent with the presence of three six-coordinate, high spin ferrous centers in $\mathbf{2}^{\mathrm{NMe}}$. 


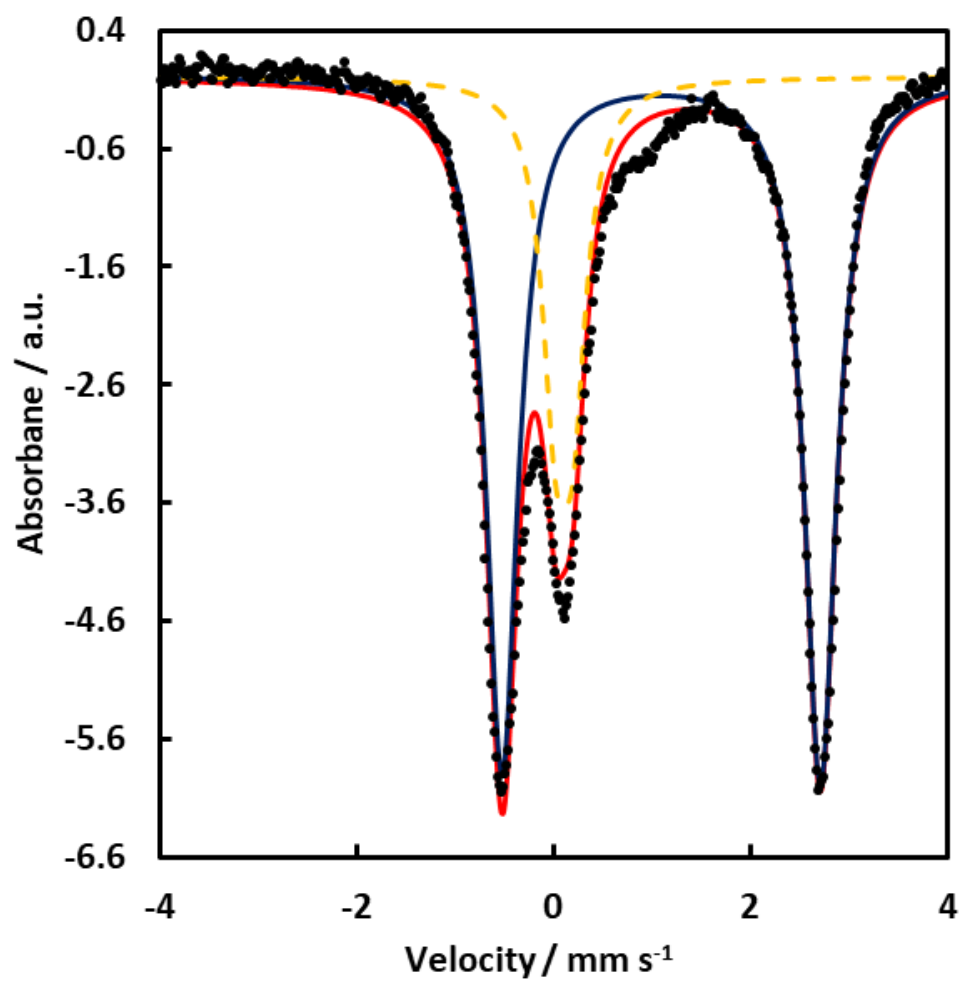

Figure S81. Zero field ${ }^{57} \mathrm{Fe}$ Mössbauer spectra $(80 \mathrm{~K})$ of $\left[\mathrm{LFe}_{3} \mathrm{O}\left({ }^{\mathrm{pNMe} 2} \mathrm{ArIm}\right){ }_{3} \mathrm{Fe}\right][\mathrm{OTf}]\left(\mathbf{2}^{\mathrm{NMe}}\right.$, microcrystalline material, black dots). The simulation assuming two distinct subsites is shown in red, with parameters: (i): $\delta=1.10 \mathrm{~mm} / \mathrm{s},\left|\Delta \mathrm{E}_{\mathrm{Q}}\right|=3.23 \mathrm{~mm} / \mathrm{s}$ (solid blue trace, $75 \%$ ); (ii): $\delta=0.11$ $\mathrm{mm} / \mathrm{s},\left|\Delta \mathrm{E}_{\mathrm{Q}}\right|=0.18 \mathrm{~mm} / \mathrm{s}$ (dashed orange trace, $25 \%$ ). 


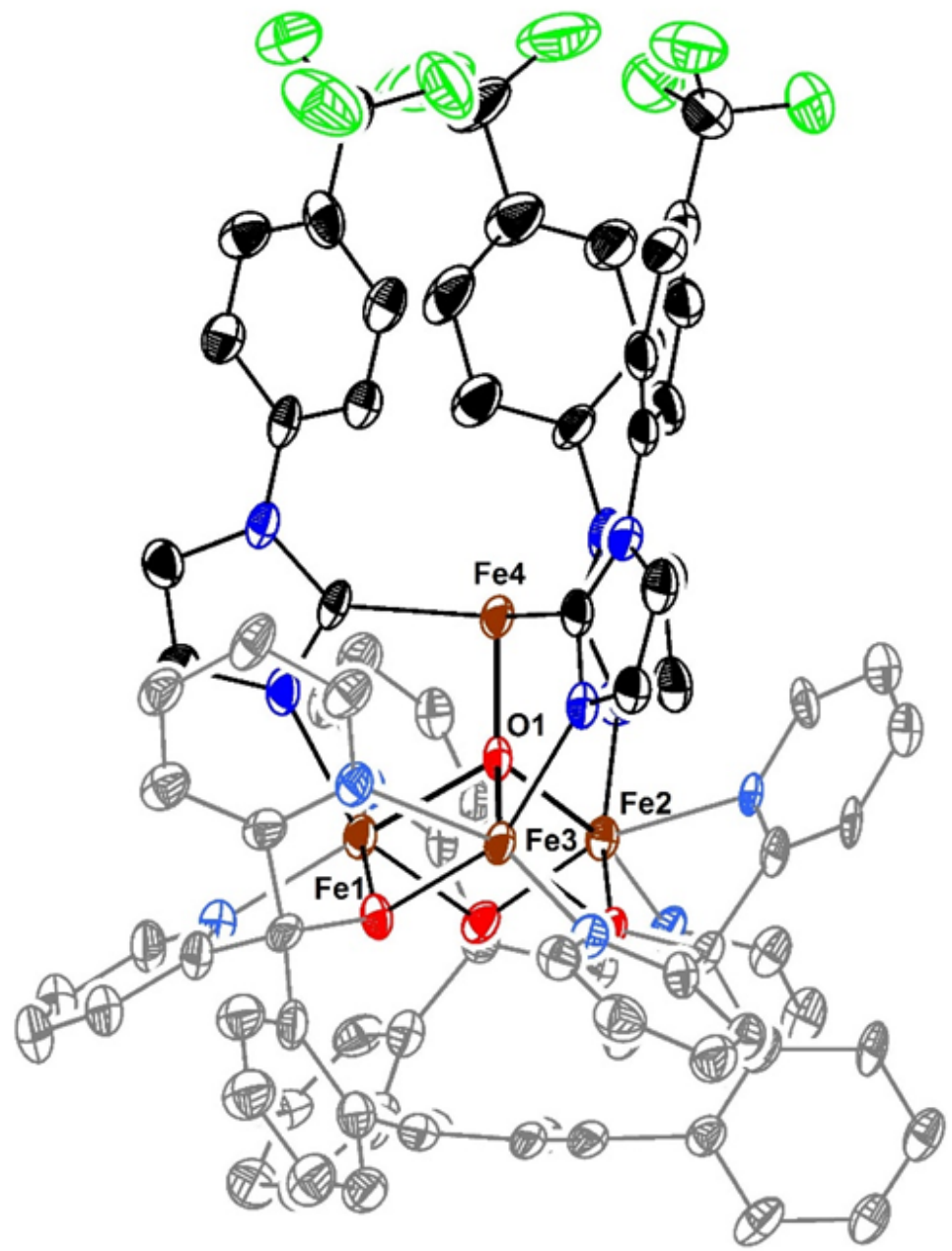

Figure S82. Crystal structure of $\left[\mathrm{LFe}_{3} \mathrm{O}\left({ }^{\mathrm{pCF}} \mathrm{ArIm}\right)_{3} \mathrm{Fe}\right][\mathrm{OTf}]_{2}\left(\mathbf{1}^{\mathrm{CF} 3}\right)$. Ellipsoids are shown at the $50 \%$ probability level. Hydrogen atoms and co-crystallized solvent molecules are not shown for clarity.

Special Refinement Details for $\left[\mathrm{LFe}_{3} \mathrm{O}\left({ }^{\mathrm{pCF} 3} \mathrm{ArIm}\right)_{3} \mathrm{Fe}\right][\mathrm{OTf}]_{2}$. Compound $\mathbf{1}^{\mathrm{CF} 3}$ crystallizes in the monoclinic space group $P 2{ }_{1}$ with two molecules in the asymmetric unit along with three molecules of co-crystallized diethyl ether. One molecule has disorder in one of the trifluoromethyl substituents. The diffraction data is not of sufficient quality for a discussion of bond lengths. However, it is enough to positively identify $\mathbf{1}^{\mathbf{C F 3}}$ as $\left[\mathrm{LFe}_{3} \mathrm{O}\left({ }^{\mathrm{pCF} 3} \mathrm{ArIm}\right)_{3} \mathrm{Fe}\right][\mathrm{OTf}]_{2}$. 


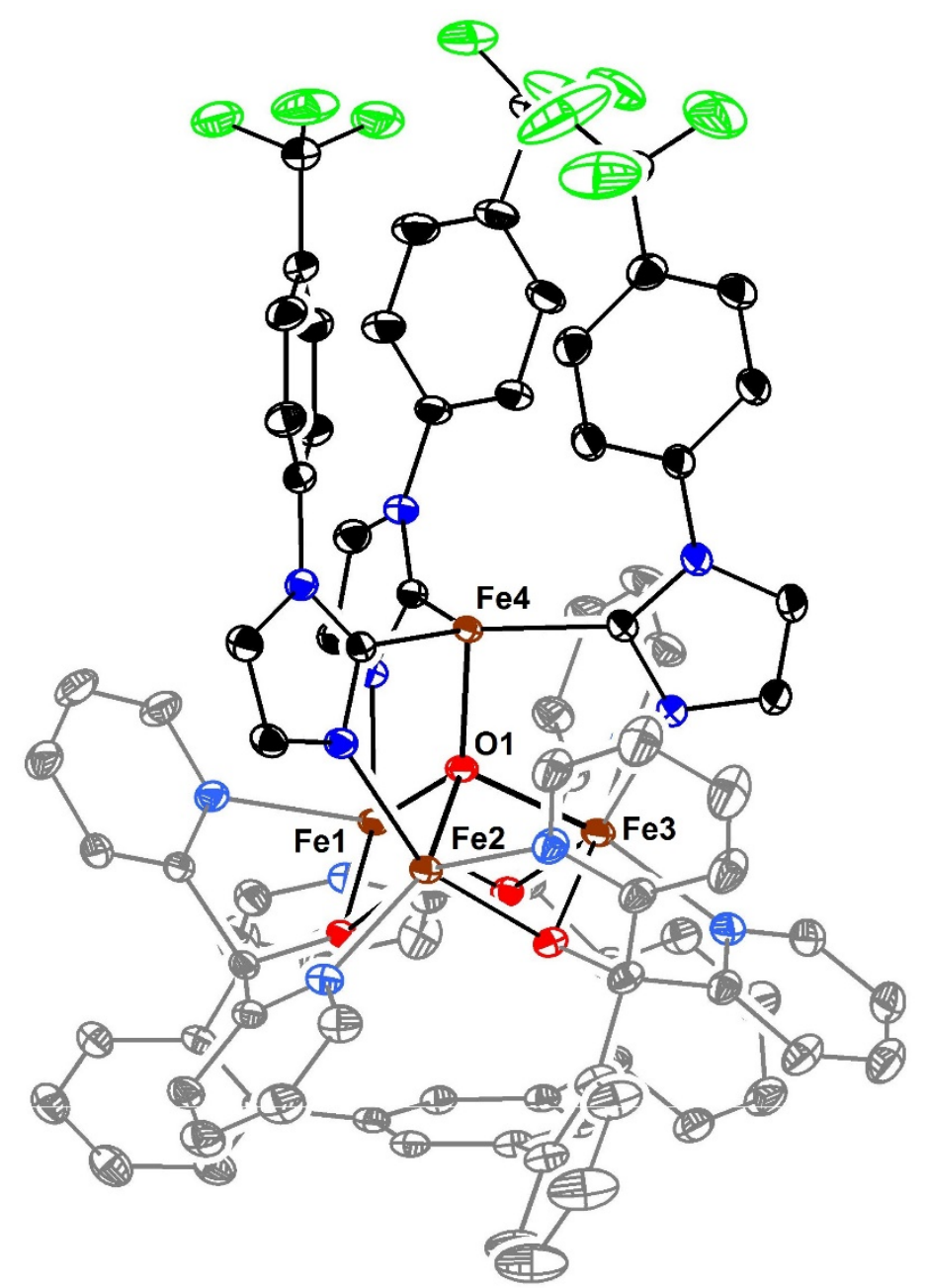

Figure S83. Crystal structure of $\left[\mathrm{LFe}_{3} \mathrm{O}\left({ }^{\mathrm{pCF} 3} \mathrm{ArIm}\right)_{3} \mathrm{Fe}\right][\mathrm{OTf}]\left(\mathbf{2}^{\mathbf{C F} 3}\right)$. Ellipsoids are shown at the $50 \%$ probability level. Hydrogen atoms and co-crystallized solvent molecules are not shown for clarity.

Special Refinement Details for [ $\left.\mathrm{LFe}_{3} \mathrm{O}\left({ }^{\mathrm{pCF}} \mathrm{ArIm}\right){ }_{3} \mathrm{Fe}\right][\mathrm{OTf}]$. Compound $2^{\mathrm{CF} 3}$ crystallizes in the monoclinic space group $P 2_{1} / \mathrm{c}$ with one molecule in the asymmetric unit along co-crystallized diethyl ether and acetonitrile. The co-crystallized acetonitrile molecule is located near a special position (inversion center) and was modelled with the aid of a similarity restraint on the 1,2 distances and enhanced rigid bond restraints on all components of the disorder. Additionally, the triflate counterion is disordered over two positions with occupancies of $63 \%$ and $37 \%$ and was modelled with the help of similarity restraints on the 1,2 distances and enhanced rigid bond restraints on all components of the disorder. 


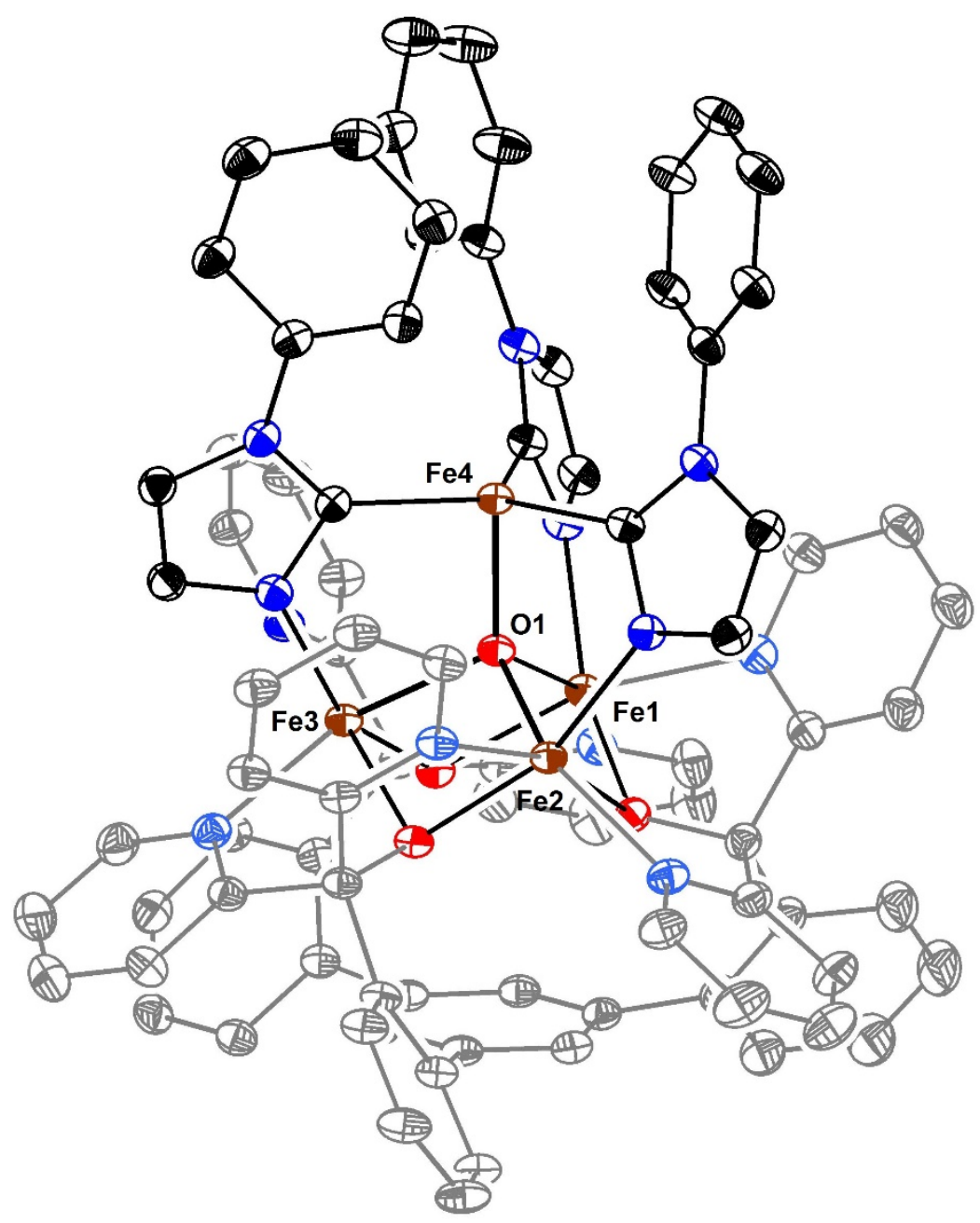

Figure S84. Crystal structure of $\left[\mathrm{LFe}_{3} \mathrm{O}(\mathrm{PhIm})_{3} \mathrm{Fe}\right]\left[\mathrm{BF}_{4}\right]\left(\mathbf{2}^{\mathbf{H}}\right)$. Ellipsoids are shown at the 50\% probability level. Hydrogen atoms and co-crystallized solvent molecules are not shown for clarity. Special Refinement Details for $\left[\mathrm{LFe}_{3} \mathrm{O}(\mathrm{PhIm})_{3} \mathrm{Fe}\right]\left[\mathrm{BF}_{4}\right]$. Compound $2^{\mathrm{H}}$ crystallizes in the monoclinic space group $\mathrm{C} 2 / \mathrm{c}$ with one molecule in the asymmetric unit along co-crystallized diethyl ether. One molecule of diethyl ether is disordered near a special position and was modelled isotropically with the aid of enhanced rigid bond restraints on all components of the disorder. Additionally, the tetrafluoroborate anion is disordered and was modelled with the help of similarity restraints on the 1,2 distances and enhanced rigid bond restraints on all components of the disorder. 


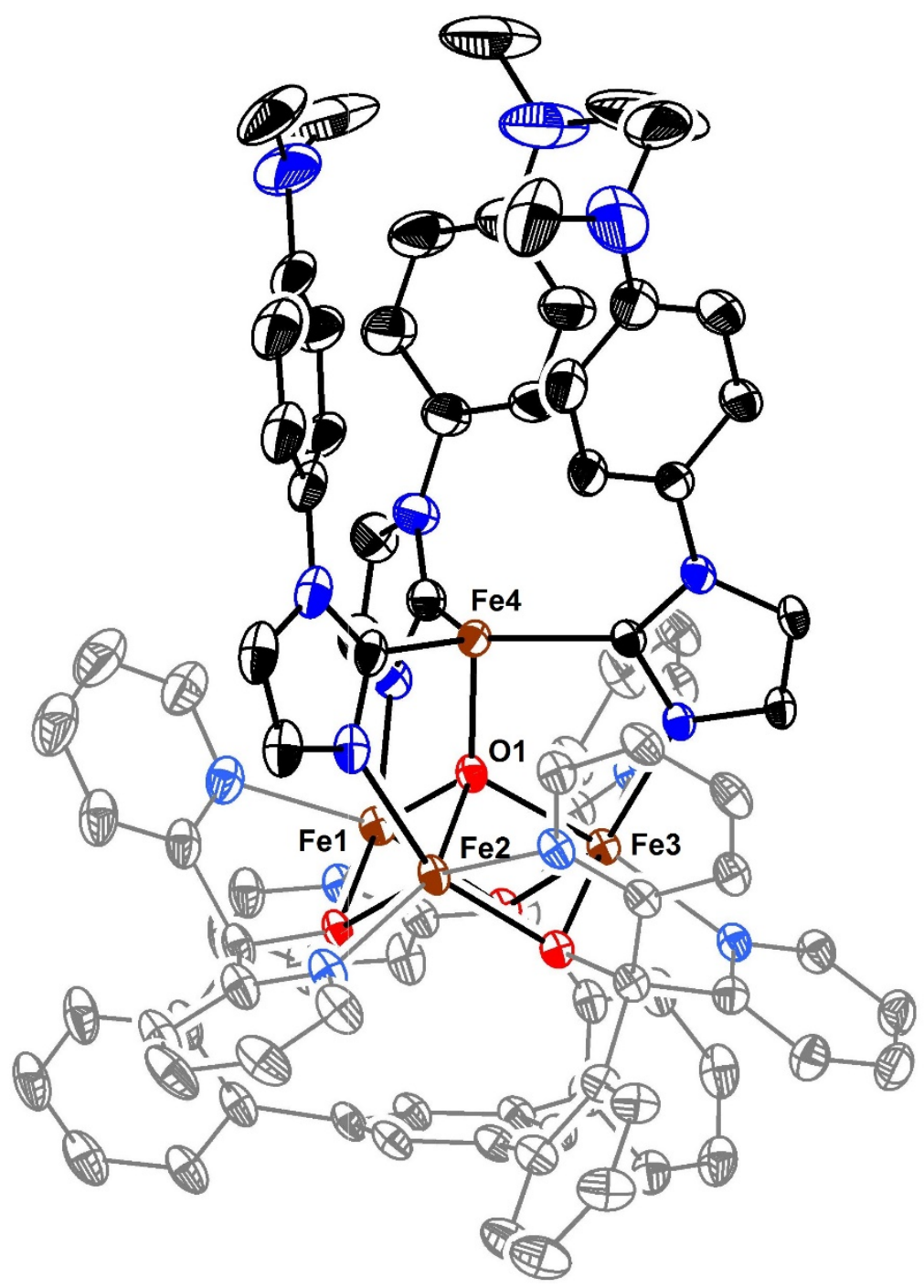

Figure S85. Crystal structure of $\left[\mathrm{LFe}_{3} \mathrm{O}\left({ }^{\mathrm{pNMe} 2} \mathrm{ArIm}\right)_{3} \mathrm{Fe}\right]\left[\mathrm{BF}_{4}\right]\left(\mathbf{2}^{\mathrm{NMe} 2}\right)$. Ellipsoids are shown at the $50 \%$ probability level. Hydrogen atoms and co-crystallized solvent molecules are not shown for clarity.

Special Refinement Details for $\left[\mathrm{LFe}_{3} \mathrm{O}\left({ }^{\mathrm{NNMe} 2} \mathrm{ArIm}\right)_{3} \mathrm{Fe}\right]\left[\mathrm{BF}_{4}\right]$. Compound $2^{\mathrm{NMe} 2}$ crystallizes in the triclinic space group P-1 with one molecule in the asymmetric unit. Additionally, the tetrafluoroborate anion is significantly disordered and was modelled isotropically. There is additional solvent disorder which could not be satisfactorily modelled and was masked in Olex 2 . The volume of the solvent accessible void space was found to be $897.0 \AA^{3}$ in which $179.4 \mathrm{e}^{-}$were located. 
$\underline{\text { X-ray Absorption Data: }}$

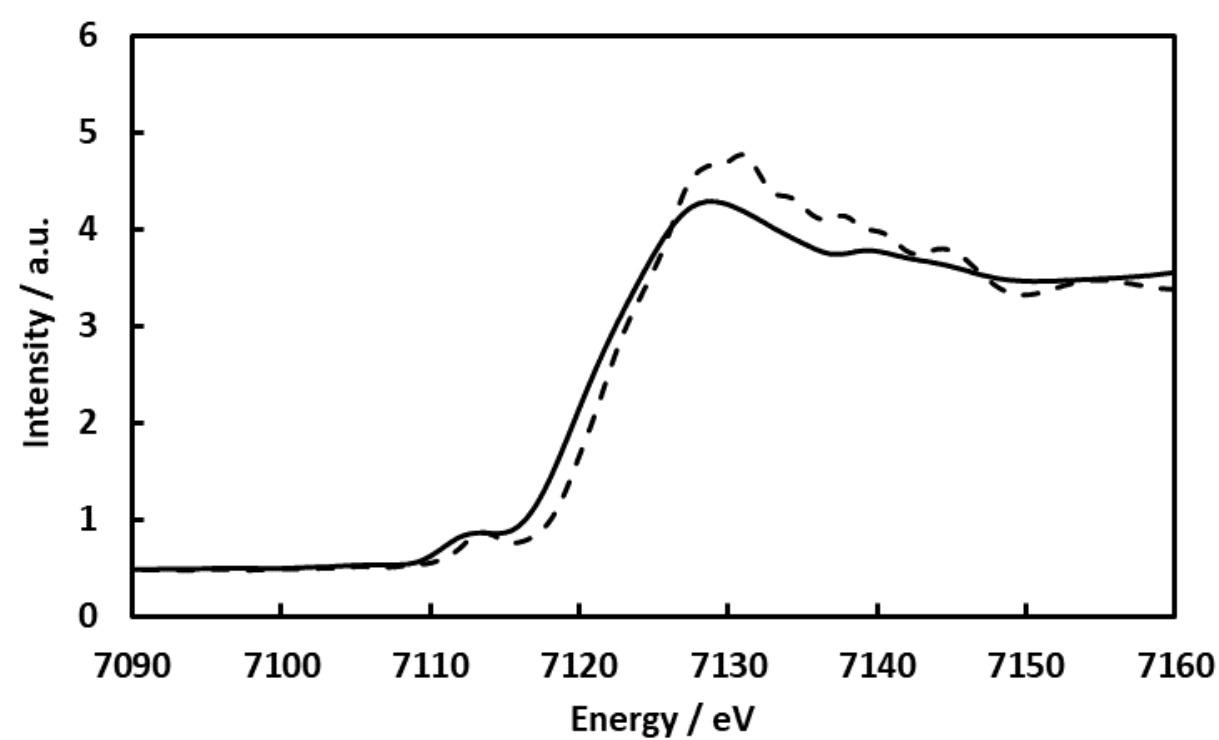

Figure S86. Fluorescence detected X-ray Absorption Spectrum of $\mathbf{2}^{\mathbf{C F} 3}$ (single crystal, black solid line) and $\mathbf{1}^{\mathbf{C F 3}}$ (single crystal, black dashed line).

\section{$\underline{\text { Anomalous Diffraction Data: }}$}

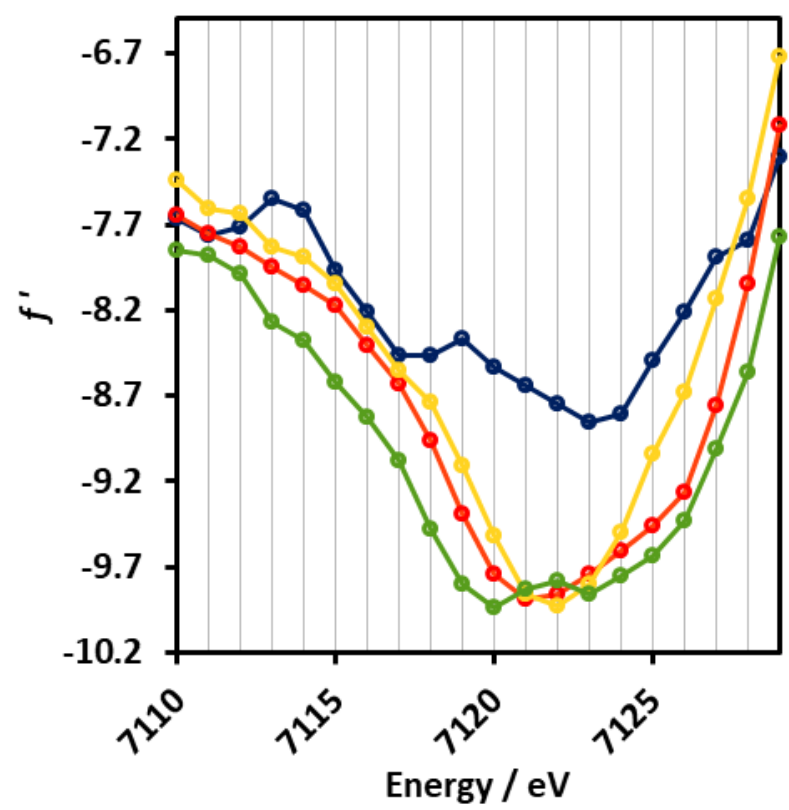

Figure S87. Plot of refined $f$ ' values for Fe1 (green), Fe2 (yellow), Fe3 (red) and Fe4(blue) as a function of energy for $\mathbf{2}^{\mathbf{C F} 3}$. Atom labels are the same as those used in the structure of $2^{\mathbf{C F 3}}$ in Figure S84. A table of selected bond lengths is included in the main text (Table 2). 


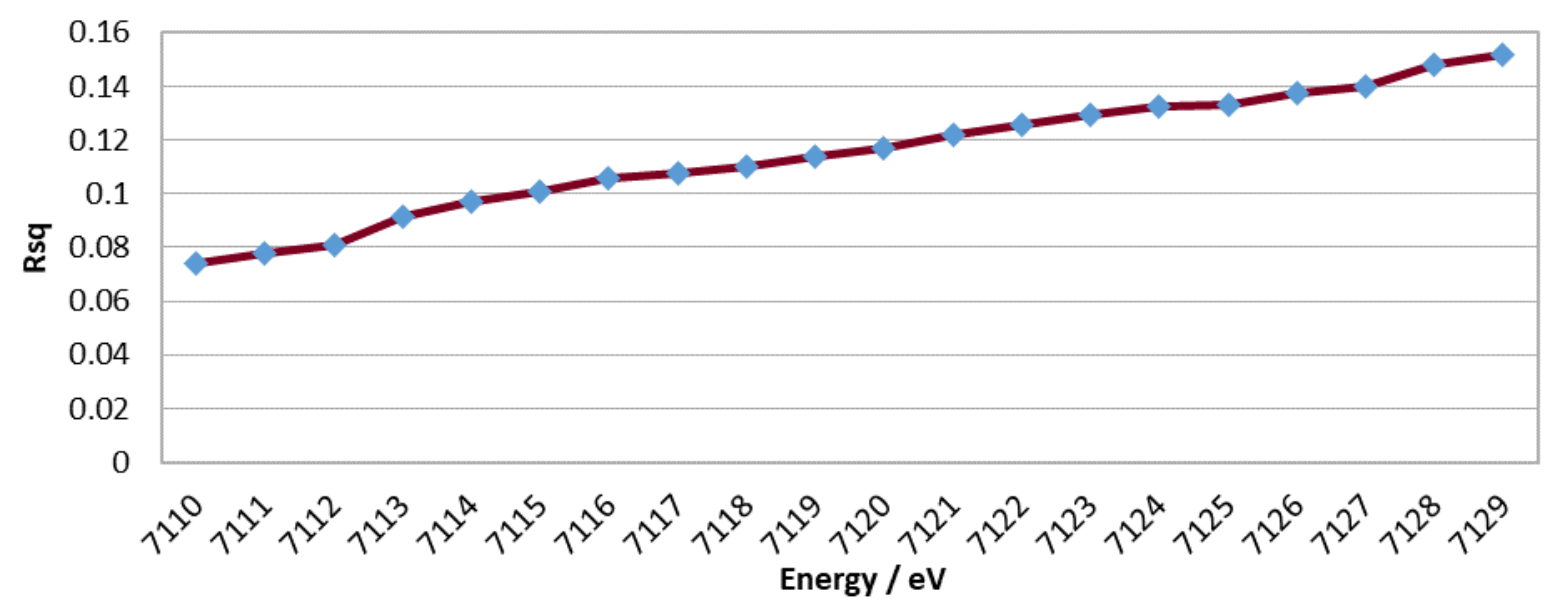

Figure S88. Refinement statistics as a function of energy for $\mathbf{2}^{\mathbf{C F 3}}$.

Table S3. Summary of anomalous diffraction refinement data

\begin{tabular}{c|c|c|c|c|c}
$\mathrm{E}(\mathrm{eV})$ & $\mathrm{Fe} 4$ & $\mathrm{Fe} 3$ & $\mathrm{Fe} 2$ & $\mathrm{Fe} 1$ & Rsq \\
\hline 7110 & -7.6658 & -7.647 & -7.4462 & -7.8527 & 0.0741 \\
7111 & -7.7657 & -7.7528 & -7.6031 & -7.8773 & 0.0779 \\
7112 & -7.713 & -7.8285 & -7.6397 & -7.9909 & 0.0811 \\
7113 & -7.5505 & -7.9523 & -7.8267 & -8.275 & 0.0916 \\
7114 & -7.621 & -8.0573 & -7.8926 & -8.3751 & 0.0968 \\
7115 & -7.9696 & -8.1728 & -8.0419 & -8.6262 & 0.1007 \\
7116 & -8.2109 & -8.4083 & -8.2986 & -8.8248 & 0.1055 \\
7117 & -8.4679 & -8.6283 & -8.5497 & -9.082 & 0.1076 \\
7118 & -8.4627 & -8.9617 & -8.7418 & -9.4796 & 0.1099 \\
7119 & -8.3671 & -9.3894 & -9.105 & -9.7984 & 0.1138 \\
7120 & -8.5345 & -9.7419 & -9.5145 & -9.9351 & 0.1171 \\
7121 & -8.6383 & -9.8876 & -9.8573 & -9.831 & 0.122 \\
7122 & -8.7449 & -9.858 & -9.928 & -9.7808 & 0.1255 \\
7123 & -8.8558 & -9.7442 & -9.8042 & -9.8612 & 0.1297 \\
7124 & -8.8045 & -9.6025 & -9.5027 & -9.757 & 0.1326 \\
7125 & -8.4986 & -9.4583 & -9.0417 & -9.6377 & 0.1329 \\
7126 & -8.2091 & -9.2636 & -8.6826 & -9.4323 & 0.1376 \\
7127 & -7.8941 & -8.7553 & -8.1316 & -9.014 & 0.1401 \\
7128 & -7.7929 & -8.0439 & -7.5529 & -8.5612 & 0.1478 \\
7129 & -7.3077 & -7.1166 & -6.7189 & -7.7701 & 0.1518
\end{tabular}




\section{$\underline{\text { Summary Tables }}$}

Table S4: Crystal and refinement data for precursor complexes $\mathbf{1}^{\mathrm{CF3}}$ and $\mathbf{2}^{\mathrm{CF} 3}$.

\begin{tabular}{|c|c|c|}
\hline & Complex $1^{\mathrm{CF} 3}$ & Complex $2^{\mathrm{CF} 3}$ \\
\hline $\mathrm{CCDC}$ & 1934988 & 1934989 \\
\hline Empirical formula & $\mathrm{C}_{190} \mathrm{H}_{114} \mathrm{~F}_{30} \mathrm{Fe}_{8} \mathrm{~N}_{24} \mathrm{O}_{23} \mathrm{~S}_{4}$ & $\mathrm{C}_{93} \mathrm{H}_{57} \mathrm{~F}_{12} \mathrm{Fe}_{4} \mathrm{~N}_{12.5} \mathrm{O}_{8} \mathrm{~S}$ \\
\hline Formula weight & 4246.09 & 1960.97 \\
\hline Temperature/K & 100 & 100.01 \\
\hline Crystal system & monoclinic & monoclinic \\
\hline Space group & $\mathrm{P} 2_{1}$ & $\mathrm{P} 2{ }_{1} / \mathrm{c}$ \\
\hline $\mathrm{a} / \AA \AA$ & $14.5950(4)$ & $13.3086(8)$ \\
\hline $\mathrm{b} / \AA \AA$ & $35.8634(9)$ & $33.274(3)$ \\
\hline $\mathrm{c} / \AA$ & $19.7228(4)$ & $20.3326(16)$ \\
\hline$\alpha^{\circ}$ & 90 & 90 \\
\hline$\beta /{ }^{\circ}$ & $93.8894(14)$ & $108.717(3)$ \\
\hline$\gamma /{ }^{\circ}$ & 90 & 90 \\
\hline Volume $/ \AA^{3}$ & $10299.7(4)$ & $8527.7(11)$ \\
\hline $\mathrm{Z}$ & 2 & 4 \\
\hline$\rho_{\text {calc }} \mathrm{g} / \mathrm{cm}^{3}$ & 1.369 & 1.527 \\
\hline$\mu / \mathrm{mm}^{-1}$ & 5.575 & 0.784 \\
\hline $\mathrm{F}(000)$ & 4296 & 3978 \\
\hline Crystal size $/ \mathrm{mm}^{3}$ & $0.28 \times 0.14 \times 0.12$ & \\
\hline Radiation & $\mathrm{CuK} \alpha(\lambda=1.54178)$ & $\operatorname{MoK} \alpha(\lambda=0.71073)$ \\
\hline $2 \Theta$ range for data collection $/{ }^{\circ}$ & 6.07 to 162.082 & 4.424 to 72.51 \\
\hline Index ranges & $-17 \leq \mathrm{h} \leq 17,-44 \leq \mathrm{k} \leq 41,-22 \leq 1 \leq 24$ & $-22 \leq \mathrm{h} \leq 21,-55 \leq \mathrm{k} \leq 54,-33 \leq 1 \leq 30$ \\
\hline Reflections collected & 220688 & 110097 \\
\hline Independent reflections & $38588\left[\mathrm{R}_{\mathrm{int}}=0.0858, \mathrm{R}_{\text {sigma }}=0.0772\right]$ & $40240\left[\mathrm{R}_{\mathrm{int}}=0.0509, \mathrm{R}_{\text {sigma }}=0.0660\right]$ \\
\hline Data/restraints/parameters & $38588 / 1 / 2512$ & $40240 / 184 / 1262$ \\
\hline Goodness-of-fit on $\mathrm{F}^{2}$ & 0.991 & 1.032 \\
\hline Final $R$ indexes $[I>=2 \sigma(I)]$ & $\mathrm{R}_{1}=0.0730, \mathrm{wR}_{2}=0.1788$ & $\mathrm{R}_{1}=0.0613, \mathrm{wR}_{2}=0.1550$ \\
\hline Final $R$ indexes [all data] & $\mathrm{R}_{1}=0.0992, \mathrm{wR}_{2}=0.1957$ & $\mathrm{R}_{1}=0.1039, \mathrm{wR}_{2}=0.1825$ \\
\hline Largest diff. peak/hole / e $\AA^{-3}$ & $0.61 /-0.48$ & $1.82 /-1.00$ \\
\hline
\end{tabular}


Table S5: Crystal and refinement data for precursor complexes $\mathbf{2}^{\mathrm{H}}$ and $\mathbf{2}^{\mathrm{NMe}}$.

\begin{tabular}{|c|c|c|}
\hline & Complex 2-BF 2 & Complex 4-BF ${ }_{2}$ \\
\hline $\mathrm{CCDC}$ & 1934990 & 1934987 \\
\hline Empirical formula & $\mathrm{C}_{92} \mathrm{H}_{70} \mathrm{BF}_{4} \mathrm{Fe}_{4} \mathrm{~N}_{12} \mathrm{O}_{6}$ & $\mathrm{C}_{90} \mathrm{H}_{75} \mathrm{BF}_{4} \mathrm{Fe}_{4} \mathrm{~N}_{15} \mathrm{O}_{4}$ \\
\hline Formula weight & 1749.81 & 1740.86 \\
\hline Temperature/K & 100 & 99.99 \\
\hline Crystal system & monoclinic & triclinic \\
\hline Space group & $\mathrm{C} 2 / \mathrm{c}$ & P-1 \\
\hline $\mathrm{a} / \AA ̊$ & $40.036(3)$ & $12.2770(6)$ \\
\hline $\mathrm{b} / \AA \AA$ & $17.6569(12)$ & $18.7653(9)$ \\
\hline $\mathrm{c} / \AA$ & $25.5478(16)$ & $21.4643(10)$ \\
\hline$\alpha /{ }^{\circ}$ & 90 & $111.337(2)$ \\
\hline$\beta /{ }^{\circ}$ & $113.925(2)$ & $97.345(2)$ \\
\hline$\gamma /{ }^{\circ}$ & 90 & $96.590(2)$ \\
\hline Volume $/ \AA^{3}$ & $16508.1(19)$ & $4498.1(4)$ \\
\hline $\mathrm{Z}$ & 8 & 2 \\
\hline$\rho_{\text {calc }} \mathrm{g} / \mathrm{cm}^{3}$ & 1.408 & 1.285 \\
\hline$\mu / \mathrm{mm}^{-1}$ & 0.761 & 0.697 \\
\hline $\mathrm{F}(000)$ & 7192 & 1794 \\
\hline \multicolumn{3}{|l|}{ Crystal size $/ \mathrm{mm}^{3}$} \\
\hline Radiation & $\operatorname{MoK} \alpha(\lambda=0.71073)$ & $\operatorname{MoK} \alpha(\lambda=0.71073)$ \\
\hline $2 \Theta$ range for data collection ${ }^{\circ}$ & 4.84 to 69.042 & 4.854 to 61.332 \\
\hline Index ranges & $-63 \leq \mathrm{h} \leq 63,-28 \leq \mathrm{k} \leq 28,-40 \leq 1 \leq 40$ & $-17 \leq \mathrm{h} \leq 17,-26 \leq \mathrm{k} \leq 26,-30 \leq 1 \leq 26$ \\
\hline Reflections collected & 262068 & 79571 \\
\hline Independent reflections & $34986\left[\mathrm{R}_{\mathrm{int}}=0.0455, \mathrm{R}_{\mathrm{sigma}}=0.0290\right]$ & $27746\left[\mathrm{R}_{\text {int }}=0.0517, \mathrm{R}_{\text {sigma }}=0.0588\right]$ \\
\hline Data/restraints/parameters & $34986 / 49 / 1074$ & $27746 / 0 / 1044$ \\
\hline Goodness-of-fit on $\mathrm{F}^{2}$ & 1.058 & 1.039 \\
\hline Final $\mathrm{R}$ indexes $[\mathrm{I}>=2 \sigma(\mathrm{I})]$ & $\mathrm{R}_{1}=0.0544, \mathrm{wR}_{2}=0.1577$ & $\mathrm{R}_{1}=0.0615, \mathrm{wR}_{2}=0.1732$ \\
\hline Final $\mathrm{R}$ indexes [all data] & $\mathrm{R}_{1}=0.0736, \mathrm{wR}_{2}=0.1773$ & $\mathrm{R}_{1}=0.0792, \mathrm{wR}_{2}=0.1870$ \\
\hline Largest diff. peak/hole / e $\AA^{-3}$ & $2.41 /-0.80$ & $1.51 /-1.10$ \\
\hline
\end{tabular}

\section{$\underline{\text { References: }}$}

1. Perry, M. C.; Cui, X.; Powell, M. T.; Hou, D.-R.; Reibenspies, J. H.; Burgess, K., Optically Active Iridium Imidazol-2-ylidene-oxazoline Complexes: Preparation and Use in Asymmetric Hydrogenation of Arylalkenes. J. Am. Chem. Soc. 2003, 125 (1), 113-123.

2. $\quad$ Hagadorn, J. R.; Que, L.; Tolman, W. B., N-Donor Effects on Carboxylate Binding in Mononuclear Iron(II) Complexes of a Sterically Hindered Benzoate Ligand. Inorg. Chem. 2000, 39 (26), 6086-6090.

3. Bailey, B. C.; Basuli, F.; Huffman, J. C.; Mindiola, D. J., Terminal Titanium(IV) (Trimethylsilyl)imides Prepared by Oxidatively Induced Trimethylsilyl Abstraction. Organometallics 2006, 25 (11), 2725-2728. 
4. Del Castillo, T. J.; Thompson, N. B.; Peters, J. C., A Synthetic Single-Site Fe Nitrogenase: High Turnover, Freeze-Quench 57Fe Mössbauer Data, and a Hydride Resting State. J. Am. Chem. Soc. 2016, $138(16), 5341-5350$.

5. Arnett, C. H.; Chalkley, M. J.; Agapie, T., A Thermodynamic Model for Redox-Dependent Binding of Carbon Monoxide at Site-Differentiated, High Spin Iron Clusters. J. Am. Chem. Soc. 2018, 140 (16), 5569-5578.

6. Stoll, S.; Schweiger, A., EasySpin, a comprehensive software package for spectral simulation and analysis in EPR. Journal of Magnetic Resonance 2006, 178 (1), 42-55.

7. Chilton, N. F.; Anderson, R. P.; Turner, L. D.; Soncini, A.; Murray, K. S., PHI: A powerful new program for the analysis of anisotropic monomeric and exchange-coupled polynuclear d- and f-block complexes. Journal of Computational Chemistry 2013, 34 (13), 1164-1175.

8. APEX-II Version 2 User Manual, M86-E01078. Bruker Analytical X-ray Systems: Madison, WI, 2006.

9. Sheldrick, G., SADABS (version 2008/1): Program for Absorption Correction for Data from Area Detector Frames. University of Göttingen: 2008.

10. Sheldrick, G., A short history of SHELX. Acta Crystallographica Section A 2008, 64 (1), $112-$

122.

11. Sheldrick, G., Crystal structure refinement with SHELXL. Acta Crystallographica Section C 2015, 71 (1), 3-8.

12. Dolomanov, O. V.; Bourhis, L. J.; Gildea, R. J.; Howard, J. A. K.; Puschmann, H., OLEX2: a complete structure solution, refinement and analysis program. J. Appl. Crystallogr. 2009, 42 (2), 339-341.

13. Kabsch, W., XDS. Acta Crystallogr. Sect. D. Biol. Crystallogr. 2010, 66, 125-132.

14. Adams, P. D.; Afonine Pavel, V.; Bunkóczi, G.; Chen, V. B.; Davis, I. W.; Echols, N.; Headd, J. J.; Hung, L.-W.; Kapral, G. J.; Grosse-Kunstleve, R. W.; McCoy, A., J.; Moriarty, N. W.; Oeffner, R.; Read, R. J.; Richardson, D. C.; Richardson, J. S.; Terwilligere, T. T.; Zwarta, P. H., PHENIX: a comprehensive Python-based system for macromolecular structure solution. Acta Crystallogr. Sect. D. Biol. Crystallogr. 2010, 66, 213-221.

15. Hernández Sánchez, R.; Zheng, S.-L.; Betley, T. A., Ligand Field Strength Mediates Electron Delocalization in Octahedral $\left[\left({ }^{\mathrm{H}} \mathrm{L}\right)_{2} \mathrm{Fe}_{6}\left(\mathrm{~L}^{\prime}\right)_{m}\right]^{n+}$ Clusters. J. Am. Chem. Soc. 2015, $137(34), 11126-11143$.

16. Winter, R. F., Half-Wave Potential Splittings $\Delta \mathrm{E} 1 / 2$ as a Measure of Electronic Coupling in Mixed-Valent Systems: Triumphs and Defeats. Organometallics 2014, 33 (18), 4517-4536.

17. Barrière, F.; Camire, N.; Geiger, W. E.; Mueller-Westerhoff, U. T.; Sanders, R., Use of Medium Effects to Tune the $\Delta \mathrm{E} 1 / 2$ Values of Bimetallic and Oligometallic Compounds. J. Am. Chem. Soc. 2002, 124 (25), 7262-7263.

18. D'Alessandro, D. M.; Keene, F. R., A cautionary warning on the use of electrochemical measurements to calculate comproportionation constants for mixed-valence compounds. Dalton Trans. 2004, (23), 3950-3954.

19. Blondin, G.; Girerd, J. J., Interplay of electron exchange and electron transfer in metal polynuclear complexes in proteins or chemical models. Chem. Rev. 1990, 90 (8), 1359-1376.

20. Beinert, H.; Holm, R. H.; Münck, E., Iron-Sulfur Clusters: Nature's Modular, Multipurpose Structures. Science 1997, 277 (5326), 653-659.

21. Stoian, S. A.; Peng, Y.-R.; Beedle, C. C.; Chung, Y.-J.; Lee, G.-H.; Yang, E.-C.; Hill, S., Structural, Spectroscopic, and Theoretical Investigation of a T-Shaped [Fe3( $\mu 3-\mathrm{O})]$ Cluster. Inorg. Chem. 2017, 56 (18), 10861-10874.

22. Mitchell, K. J.; Abboud, K. A.; Christou, G., Magnetostructural Correlation for High-Nuclearity Iron(III)/Oxo Complexes and Application to Fe5, Fe6, and Fe8 Clusters. Inorg. Chem. 2016, 55 (13), 6597-6608.

23. Phillips, J. J.; Peralta, J. E.; Christou, G., Magnetic Couplings in Spin Frustrated Fe7III Disklike Clusters. Journal of Chemical Theory and Computation 2013, 9 (12), 5585-5589.

24. $\quad$ Sameera, W. M. C.; Piñero, D. M.; Herchel, R.; Sanakis, Y.; McGrady, J. E.; Raptis, R. G.; Zueva, E. M., A Combined Experimental and Computational Study of the Magnetic Superexchange 
within a Triangular ( $\mu 3-\mathrm{O})$-Pyrazolato-FeIII3 Complex. Eur. J. Inorg. Chem. 2012, 2012 (21), 35003506.

25. Mukherjee, S.; Bagai, R.; Abboud, K. A.; Christou, G., Raising the Spin of FeIII7 Disklike Clusters: The Power of Molecular Spin Frustration. Inorg. Chem. 2011, 50 (9), 3849-3851.

26. Baran, P.; Boča, R.; Chakraborty, I.; Giapintzakis, J.; Herchel, R.; Huang, Q.; McGrady, J. E.; Raptis, R. G.; Sanakis, Y.; Simopoulos, A., Synthesis, Characterization, and Study of Octanuclear IronOxo Clusters Containing a Redox-Active Fe4O4-Cubane Core. Inorg. Chem. 2008, 47 (2), 645-655.

27. Piñero, D.; Baran, P.; Boca, R.; Herchel, R.; Klein, M.; Raptis, R. G.; Renz, F.; Sanakis, Y., A Pyrazolate-Supported Fe3( $\mu 3-\mathrm{O})$ Core: Structural, Spectroscopic, Electrochemical, and Magnetic Study. Inorg. Chem. 2007, 46 (26), 10981-10989.

28. Cañada-Vilalta, C.; O'Brien, T. A.; Brechin, E. K.; Pink, M.; Davidson, E. R.; Christou, G., Large Spin Differences in Structurally Related Fe6 Molecular Clusters and Their Magnetostructural Explanation. Inorg. Chem. 2004, 43 (18), 5505-5521.

29. Gorun, S. M.; Lippard, S. J., Magnetostructural correlations in magnetically coupled (.mu.oxo)diiron(III) complexes. Inorg. Chem. 1991, 30 (7), 1625-1630.

30. Weihe, H.; Güdel, H. U., Angular and Distance Dependence of the Magnetic Properties of OxoBridged Iron(III) Dimers. J. Am. Chem. Soc. 1997, 119 (28), 6539-6543.

31. Tsui, E. Y.; Kanady, J. S.; Day, M. W.; Agapie, T., Trinuclear first row transition metal complexes of a hexapyridyl, trialkoxy 1,3,5-triarylbenzene ligand. Chem. Commun. 2011, 47 (14), 41894191.

32. Snyder, B. S.; Patterson, G. S.; Abrahamson, A. J.; Holm, R. H., Binuclear iron system ferromagnetic in three oxidation states: synthesis, structures, and electronic aspects of molecules with a Fe2(OR)2 bridge unit containing Fe(III,III), Fe(III,II), and Fe(II,II). J. Am. Chem. Soc. 1989, 111 (14), 5214-5223.

33. Tabernor, J.; Jones, L. F.; Heath, S. L.; Muryn, C.; Aromí, G.; Ribas, J.; Brechin, E. K.; Collison, D., A centred, elongated 'ferric tetrahedron' with an $S=15 / 2$ spin ground state. Dalton Trans. 2004, (7), 975-976.

34. Chen, S.; Mereacre, V.; Anson, C. E.; Powell, A. K., A single molecule magnet to single molecule magnet transformation via a solvothermal process: Fe4Dy2 $\rightarrow$ Fe6Dy3. Dalton Trans. 2016, 45 (1), 98-106.

35. Murali, M.; Nayak, S.; Costa, J. S.; Ribas, J.; Mutikainen, I.; Turpeinen, U.; Clémancey, M.; Garcia-Serres, R.; Latour, J.-M.; Gamez, P.; Blondin, G.; Reedijk, J., Discrete Tetrairon(III) Cluster Exhibiting a Square-Planar Fe4( $\mu 4-\mathrm{O})$ Core: Structural and Magnetic Properties. Inorg. Chem. 2010, 49 (5), 2427-2434.

36. Govor, E. V.; Al-Ameed, K.; Chakraborty, I.; Coste, C. S.; Govor, O.; Sanakis, Y.; McGrady, J. E.; Raptis, R. G., A Redox-Induced Spin-State Cascade in a Mixed-Valent Fe3( $\mu 3-O)$ Triangle. Angew. Chem. Int. Ed. 2017, 56 (2), 582-586.

37. Le Bideau, J.; Papoutsakis, D.; Jackson, J. E.; Nocera, D. G., Toward Prediction of Magnetic Properties in Layered Vanadyl Phosphonates: Correlation of Magnetic Exchange with the Hammett $\sigma$ Parameter. J. Am. Chem. Soc. 1997, 119 (6), 1313-1316.

38. Kahn, O., Molecular Magnetism. VCH Publishers, Inc.: New York, 1993.

39. Belinsky, M. I., Anisotropic mixing of spin levels in spin-admixed tetrameric iron-sulfur clusters with spin frustration. Chem. Phys. 2002, 277 (3), 271-296.

40. Carney, M. J.; Papaefthymiou, G. C.; Whitener, M. A.; Spartalian, K.; Frankel, R. B.; Holm, R. H., Alternative spin states in synthetic analogs of biological clusters: spin-quartet ground states and structures of tetrakis(benzenethiolato)tetrasulfidotetraferrate(3-) and tetrakis(benzenethiolato)tetraselenidotetraferrate(3-) as their tetramethylammonium salts. Inorg. Chem. 1988, 27 (2), 346-352.

41. Carney, M. J.; Papaefthymiou, G. C.; Spartalian, K.; Frankel, R. B.; Holm, R. H., Ground spin state variability in [Fe4S4(SR)4]3-. Synthetic analogs of the reduced clusters in ferredoxins and other 
iron-sulfur proteins: cases of extreme sensitivity of electronic state and structure to extrinsic factors. $J$. Am. Chem. Soc. 1988, 110 (18), 6084-6095.

42. R. Hagen, W.; A. M. van den Berg, W.; M. A. M. van Dongen, W.; J. Reijerse, E.; J. M. van Kan, P., EPR spectroscopy of biological iron-sulfur clusters with spin-admixed $\mathrm{S}=3 / 2$. J. Chem. Soc., Faraday Trans. 1998, 94 (19), 2969-2973.

43. Harman, W. H.; Harris, T. D.; Freedman, D. E.; Fong, H.; Chang, A.; Rinehart, J. D.; Ozarowski, A.; Sougrati, M. T.; Grandjean, F.; Long, G. J.; Long, J. R.; Chang, C. J., Slow Magnetic Relaxation in a Family of Trigonal Pyramidal Iron(II) Pyrrolide Complexes. J. Am. Chem. Soc. 2010, 132 (51), 1811518126.

44. Boča, R., Zero-field splitting in metal complexes. Coord. Chem. Rev. 2004, 248 (9), 757-815.

45. Chakrabarti, M.; Deng, L.; Holm, R. H.; Münck, E.; Bominaar, E. L., Mössbauer, Electron Paramagnetic Resonance, and Theoretical Studies of a Carbene-Based All-Ferrous Fe4S4 Cluster: Electronic Origin and Structural Identification of the Unique Spectroscopic Site. Inorg. Chem. 2009, 48 (7), 2735-2747.

46. Yoo, S. J.; Angove, H. C.; Burgess, B. K.; Hendrich, M. P.; Münck, E., Mössbauer and IntegerSpin EPR Studies and Spin-Coupling Analysis of the $[4 \mathrm{Fe}-4 \mathrm{~S}]^{0}$ Cluster of the Fe Protein from Azotobacter vinelandii Nitrogenase. J. Am. Chem. Soc. 1999, 121 (11), 2534-2545.

47. Angove, H. C.; Yoo, S. J.; Burgess, B. K.; Münck, E., Mössbauer and EPR Evidence for an AllFerrous Fe4S4 Cluster with $\mathrm{S}=4$ in the Fe Protein of Nitrogenase. J. Am. Chem. Soc. 1997, 119 (37), $8730-8731$.

48. Münck, E.; Ksurerus, K.; Hendrich, M. P., Combining Mössbauer spectroscopy with integer spin electron paramagnetic resonance. In Methods Enzymol., Academic Press: 1993; Vol. 227, pp 463-479. 49. Surerus, K. K.; Hendrich, M. P.; Christie, P. D.; Rottgardt, D.; Orme-Johnson, W. H.; Munck, E., Moessbauer and integer-spin EPR of the oxidized P-clusters of nitrogenase: POX is a non-Kramers system with a nearly degenerate ground doublet. J. Am. Chem. Soc. 1992, 114 (22), 8579-8590.

50. Hendrich, M. P.; Debrunner, P. G., Integer-spin electron paramagnetic resonance of iron proteins. Biophysical Journal 56 (3), 489-506.

51. Herbert, D. E.; Lionetti, D.; Rittle, J.; Agapie, T., Heterometallic Triiron-Oxo/Hydroxo Clusters: Effect of Redox-Inactive Metals. J. Am. Chem. Soc. 2013, 135 (51), 19075-19078.

52. de Ruiter, G.; Thompson, N. B.; Lionetti, D.; Agapie, T., Nitric Oxide Activation by Distal Redox Modulation in Tetranuclear Iron Nitrosyl Complexes. J. Am. Chem. Soc. 2015, 137 (44), 1409414106.

53. Gouré, E.; Carboni, M.; Dubourdeaux, P.; Clémancey, M.; Balasubramanian, R.; Lebrun, C.; Bayle, P.-A.; Maldivi, P.; Blondin, G.; Latour, J.-M., Cis/Trans Isomerizations in Diiron Complexes Involving Aniline or Anilide Ligands. Inorg. Chem. 2014, 53 (19), 10060-10069.

54. Sutradhar, M.; Carrella, L. M.; Rentschler, E., A Discrete $\mu_{4}$-Oxido Tetranuclear Iron(III) Cluster. Eur. J. Inorg. Chem. 2012, 2012 (27), 4273-4278.

55. Singh, A. K.; Jacob, W.; Boudalis, A. K.; Tuchagues, J.-P.; Mukherjee, R., A Tetragonal Core with Asymmetric Iron Environments Supported Solely by Bis $(\mu-\mathrm{OH})\{\mu-(\mathrm{O}-\mathrm{H} \cdots \mathrm{O})\}$ Bridging and Terminal Pyridine Amide (N, O) Coordination: A New Member of the Tetrairon(III) Family. Eur. J. Inorg. Chem. 2008, 2008 (18), 2820-2829.

56. Chardon-Noblat, S.; Horner, O.; Chabut, B.; Avenier, F.; Debaecker, N.; Jones, P.; Pécaut, J.; Dubois, L.; Jeandey, C.; Oddou, J.-L.; Deronzier, A.; Latour, J.-M., Spectroscopic and Electrochemical Characterization of an Aqua Ligand Exchange and Oxidatively Induced Deprotonation in Diiron Complexes. Inorg. Chem. 2004, 43 (5), 1638-1648.

57. Reynolds, R. A.; Coucouvanis, D., Mixed Carboxylate/Catecholate Bridged Polynuclear Complexes. Tetranuclear Linear Arrays and Pentanuclear Clusters with $\left[\mathrm{M}_{4} \mathrm{M}^{\prime} \mathrm{O}_{8}\right]^{3+}$ Cores $\left(\mathrm{M}=\mathrm{Fe}^{2+}\right.$, $\left.\mathrm{Mn}^{2+} ; \mathrm{M}^{\varsigma}=\mathrm{Fe}^{3+}, \mathrm{Mn}^{3+}\right)$. Rare Examples of Dodecahedrally Coordinated, First Row, Trivalent Metal Ions. Inorg. Chem. 1998, 37 (2), 170-171.

58. Gütlich, P.; Bill, E.; Trautwein, A. X., Mössbauer Spectroscopy and Transition Metal Chemistry: Fundamentals and Applications. Springer: Berlin, 2011. 
59. Venkateswara Rao, P.; Holm, R. H., Synthetic Analogues of the Active Sites of Iron-Sulfur Proteins. Chem. Rev. 2004, 104 (2), 527-560.

60. Fohlmeister, L.; Vignesh, K. R.; Winter, F.; Moubaraki, B.; Rajaraman, G.; Pottgen, R.; Murray, K. S.; Jones, C., Neutral diiron(iii) complexes with $\mathrm{Fe}_{2}(\mu-\mathrm{E})_{2}(\mathrm{E}=\mathrm{O}, \mathrm{S}, \mathrm{Se})$ core structures: reactivity of an iron(i) dimer towards chalcogens. Dalton Transactions 2015, 44 (4), 1700-1708.

61. Bergner, M.; Dechert, S.; Demeshko, S.; Kupper, C.; Mayer, J. M.; Meyer, F., Model of the MitoNEET [2Fe-2S] Cluster Shows Proton Coupled Electron Transfer. J. Am. Chem. Soc. 2017, 139 (2), 701-707.

62. Yao, S.; Meier, F.; Lindenmaier, N.; Rudolph, R.; Blom, B.; Adelhardt, M.; Sutter, J.; Mebs, S.; Haumann, M.; Meyer, K.; Kaupp, M.; Driess, M., Biomimetic [2Fe-2S] Clusters with Extensively Delocalized Mixed-Valence Iron Centers. Angew. Chem. Int. Ed. 2015, 54 (42), 12506-12510.

63. Lee, Y.; Jeon, I.-R.; Abboud, K. A.; Garcia-Serres, R.; Shearer, J.; Murray, L. J., A [3Fe-3S] ${ }^{3+}$ cluster with exclusively $\mu$-sulfide donors. Chem. Commun. 2016, 52 (6), 1174-1177.

64. Reed, C. J.; Agapie, T., Thermodynamics of Proton and Electron Transfer in Tetranuclear Clusters with $\mathrm{Mn}-\mathrm{OH}_{2} / \mathrm{OH}$ Motifs Relevant to $\mathrm{H}_{2} \mathrm{O}$ Activation by the Oxygen Evolving Complex in Photosystem II. J. Am. Chem. Soc. 2018, 140 (34), 10900-10908.

65. Reed, C. J.; Agapie, T., Tetranuclear Fe Clusters with a Varied Interstitial Ligand: Effects on the Structure, Redox Properties, and Nitric Oxide Activation. Inorg. Chem. 2017, 56 (21), 13360-13367.

66. de Ruiter, G.; Carsch, K. M.; Gul, S.; Chatterjee, R.; Thompson, N. B.; Takase, M. K.; Yano, J.; Agapie, T., Accelerated Oxygen Atom Transfer and $\mathrm{C}-\mathrm{H}$ Bond Oxygenation by Remote Redox Changes in $\mathrm{Fe}_{3} \mathrm{Mn}-$ Iodosobenzene Adducts. Angew. Chem. Int. Ed. 2017, 56 (17), 4772-4776.

67. de Ruiter, G.; Thompson, N. B.; Takase, M. K.; Agapie, T., Intramolecular C-H and C-F Bond Oxygenation Mediated by a Putative Terminal Oxo Species in Tetranuclear Iron Complexes. J. Am. Chem. Soc. 2016, 138 (5), 1486-1489.

68. Borovik, A. S.; Murch, B. P.; Que, L.; Papaefthymiou, V.; Munck, E., Models for iron-oxo proteins: a mixed valence iron(II)-iron(III) complex. J. Am. Chem. Soc. 1987, 109 (23), 7190-7191.

69. Smith, J. M.; Mayberry, D. E.; Margarit, C. G.; Sutter, J.; Wang, H.; Meyer, K.; Bontchev, R. P., $\mathrm{N}-\mathrm{O}$ Bond Homolysis of an Iron(II) TEMPO Complex Yields an Iron(III) Oxo Intermediate. J. Am. Chem. Soc. 2012, 134 (15), 6516-6519.

70. Vogel, C.; Heinemann, F. W.; Sutter, J.; Anthon, C.; Meyer, K., An Iron Nitride Complex. Angew. Chem. Int. Ed. 2008, 47 (14), 2681-2684. 